\author{
UNIVERSIDADE DE SÃO PAULO \\ FACULDADE DE FILOSOFIA, LETRAS E CIÊNCIAS HUMANAS \\ DEPARTAMENTO DE GEOGRAFIA \\ PROGRAMA DE PÓS-GRADUAÇÃO EM GEOGRAFIA FÍSICA
}

ADRIANA SALVIATO ULLER

"CARTOGRAFIA TURÍSTICA:

Uma Leitura dos Mapas Temáticos de Uso do Turista

em Ponta Grossa - Paraná”

v.1

São Paulo

2010 


\author{
UNIVERSIDADE DE SÃO PAULO \\ FACULDADE DE FILOSOFIA, LETRAS E CIÊNCIAS HUMANAS \\ DEPARTAMENTO DE GEOGRAFIA \\ PROGRAMA DE PÓS-GRADUAÇÃO EM GEOGRAFIA FÍSICA
}

\title{
“CARTOGRAFIA TURÍSTICA: \\ Uma Leitura dos Mapas Temáticos de Uso do Turista em Ponta Grossa - Paraná"
}

\section{ADRIANA SALVIATO ULLER}

Tese apresentada como critério essencial de aprovação no curso de doutorado em Geografia Física do Departamento de Geografia da Faculdade de Filosofia, Letras e Ciências Humanas da Universidade de São Paulo.

Orientadora: Profa. Dra. Maria Elena Ramos Simielli 


\section{DEDICATÓRIA}

Dedico este trabalho a todos aqueles que estudam, trabalham, se esforçam e se dedicam para progredir, ultrapassando limites e barreiras para fazer desse mundo um lugar mais digno, mais evoluído, mais pacífico e melhor de se viver. Parafraseando Érico Veríssimo eu complemento dizendo: estes seres sabem que a felicidade está na certeza de que nossa vida não está se passando inutilmente, e este exemplo que carrego e tento ser, eu herdo de meus pais e esposo, e, o deixo aos meus filhos, alunos e futuras gerações. 


\section{AGRADECIMENTOS}

Em meu âmbito espiritual, agradeço a Deus, fonte de minha inspiração e de toda a minha força, para superar os obstáculos e persistir em metas grandiosas, que me fazem, não só uma pessoa de bem, mas, alguém que faz valer cada dia de vida, doandose em produção para um mundo melhor;

No aspecto pessoal, inúmeras foram os que participaram da minha caminhada de forma positiva, seja na vida privada, ou, na vida acadêmica. A essas pessoas ofereço minha gratidão e espero, sinceramente, que possa um dia retribuir.

A toda a minha família, irmão, cunhados, tios, primos e em especial aos meus pais Maria Eloiza e Leonildo Salviato, ao meu esposo e amigo Waldir Uller, e meus filhos, Amanda e Wallace, que são a minha raiz, origem e continuidade dos meus bons princípios, e também a minha fortaleza, na sustentação do meu caminhar; sem eles eu não estaria aqui, bem como não teria anseios para chegar a lugar algum.

À Professora Doutora Maria Elena Ramos Simieli, pelo companheirismo e orientação em meus caminhos científicos rumo a um saber cartográfico mais aprofundado, na certeza de que sempre temos muito a aprender.

Ao jovem casal Claudete e Luciano Bittencourt que tantas vezes foram meu ombro, nas crises e, minha motivação, na hora em que era preciso continuar.

Aos meus amigos, que de longe ou perto sempre me apóiam, torcem por mim, me auxiliam em inúmeras situações e, estendem palavras de otimismo quando eu penso em desanimar. Em especial o meu muito obrigada à Leila Cleury Pryjma, Clevoneide do Carmo Oliveira, Franciane Santana, Solange Pimentel, Nilcéia e Luís Guimarães, Luciana Antunes, Dyene e Anderson Garret, Lúcia Pescador e Família Carraro. 
Às minhas amigas secretárias Denise e Rosane Araújo, pela ajuda, dedicação e tomada de decisões, nos momentos em que eu não me encontrava presente. Sem elas eu teria entrado ainda mais em pânico.

À grande amiga paulistana Marinyl Ribeiro da Silva, pela companhia nos estudos em várias disciplinas na USP e em eventos científicos da área, pela constante colaboração com envio de materiais e/ou informações, pela confiança em nos chamar carinhosamente de "co-orientadora" e pelo enorme afeto que fez com essa amizade transcendesse os muros da Universidade e se transformasse em um elo verdadeiro e muito forte, no campo científico e também pessoal.

À ex-aluna, hoje estagiária e amiga Dayana Caillot Schroeder Lesiko, pela ajuda em diversos momentos da pesquisa, coletando materiais, fazendo contatos necessários, aplicando entrevistas, auxiliando nas tabulações e correções das normas técnicas; demonstrando que amizade pode ser afeto, mas também trabalho e solidariedade nos momentos de necessidade.

Aos amigos, professores e escritores, Michele Pupo e Fábio Henrique Pupo, pelo enorme auxílio na correção do português e nas traduções do espanhol e inglês, corroborando para o meu entendimento, e também para minhas expressões escritas.

Ao jovem colega Emerson Cervi - Jornalista Doutorando em Políticas Sociais, Professor do Departamento de Comunicação da UEPG, pelo apoio em nossa prática metodológica, com orientações para aplicação estatística e interpretações quantitativas.

Aos Estagiários de Geografia: Douglas, Priscila, Ricardo e Mayã, na aplicação das entrevistas; creio que um breve aprendizado para o caminho que estão começando a trilhar, mas uma grande contribuição para esta etapa do meu percurso.

Não poderia me esquecer de estender meus agradecimentos às instituições que me acolheram e me deram total apoio no desenvolver dessa pesquisa. 
À USP, em especial à FFLCH e ao Departamento de Geografia - que me aceitou como pós-graduanda e em toda a sua competência fez expandir os meus pensamentos científicos através de seus maravilhosos professores titulares e convidados, em especial Professor Dr. Marcello Martinelli, Professora Dra. Magda Lombardo, Prof. Dr. Ailton Luchiari, Prof. Dr. Reinaldo Paul Perez Machado, Professora Dra Maria Laura da Silveira, e também no pronto atendimento por parte da coordenação do Prof. Emerson Galvani, e da equipe de secretaria, Jurema, Ana, Cida e demais funcionários que me faltam nesse momento à lembrança dos nomes.

À UEPG, em especial ao DEGEO (Departamento de Geociências) no qual atuo, e a Propesp (Pró-Reitoria de Pesquisa e Pós-Graduação), por terem colaborado com a permissão de meu afastamento para continuar os meus estudos, com certeza retornarei melhor, no meu trabalho e como pessoa.

Ao CNPq (Conselho Nacional de Desenvolvimento Científico e Tecnológico), pela ajuda financeira, que permitiu tranqüilidade para meus deslocamentos, estadas fora de casa, e aquisição de materiais diversos, inclusive de máxima urgência e no exterior.

Ao IAP - Instituto Ambiental do Paraná pela autorização de realização da Pesquisa nas RPPNs e ao Parque Estadual de Vila Velha, pela permissão de entrevistas e convívio durante este período;

À ORBIPLAN - Consultoria Ambiental e Planejamento Turístico e seu responsável Marcos, Turismólogo e Doutorando em Geografia - elaborador do mapa turístico atualizado de Ponta Grossa;

Ao Departamento Municipal de Turismo - que na pessoa de suas diretoras Marcia e Larissa, estendeu-nos apoio a pesquisa, oferecendo materiais e dados documentais.

\footnotetext{
Este trabalho contou com o apoio do $\mathrm{CNPq}-$
}

(Conselho Nacional de Desenvolvimento Científico e Tecnológico -

"National Counsel of Technological and Scientific Development") 


\section{EPÍGRAFE}

"[...] Conocer y pensar no es llegar a uma verdad absolutamente cierta, es dialogar com la incertumbre". (MORIM, 2000) 


\section{RESUMO}

Este trabalho é resultado de uma tese de doutorado realizada na Universidade de São Paulo, com o objetivo de: "Analisar a forma de representação cartográfica temática presente nos mapas turísticos destinados aos visitantes no Município de Ponta Grossa PR". Tal intuito veio de encontro à problemática observada nos diferentes usos simbólicos em mapas ofertados aos turistas, em diferentes localidades do Estado do Paraná e até mesmo do País, criando uma imagem local muitas vezes não correspondente à realidade identitária cultural destes respectivos espaços. No caso do Município de Ponta Grossa - PR (recorte espacial escolhido para estudo), os mapas turísticos focalizam com grande ênfase o Parque Estadual de Vila Velha, deixando pouco retratados, ou de difícil localização, outros pontos turísticos importantes como: Buraco do Padre, Cachoeira da Mariquinha, Rio Verde, Capão da Onça, Parque Margharita Mazzine, Vila Hilda, Estação Saudade e tantos mais. Isto permite de certa forma condenar o município a uma espécie de extensão da capital estadual (Curitiba), dentro dos roteiros turísticos, penalizando fortemente este setor econômico, e, maculando de insignificantes outras potencialidades naturais e culturais locais. Assim, apesar de um número expressivo de visitantes que vem até o município, estes turistas praticamente só comparecem até o Parque e já retornam, sem visitar demais áreas e sem sequer conhecer a cidade. O resultado desse descaso é o desinteresse de maiores políticas públicas que fomentem uma ampliação nas infraestruturas de acesso, de atendimento, de acomodação e até mesmo de dinamização frente ao que poderia ser um salto para o turismo sustentável local. No desenvolvimento da pesquisa, utilizamos como metodologia de trabalho a análise de materiais cartográficos (mapas turísticos) e as entrevistas com usuários do serviço (turistas e visitantes locais), diagnosticando a eficácia da representação simbólica empregada nos dois mapas mais atualizados, correlacionando isto às causas e consequências do resultado de tal material produzido, como instrumento de marketing, de localização e informação. Também foram entrevistados os sujeitos responsáveis pela produção do material de divulgação aos visitantes, para saber sua formação profissional e critérios considerados importantes na elaboração dos mapas, bem como os chefes de departamento de turismo, para permitir um entendimento, frente ao ponto de vista dos mesmos, quanto ao tipo de material ofertado, fazendo uma correlação com os dados quantitativos obtidos no campo de investigação anterior. Nossos estudos se basearam com prioridade às concepções teóricas atuais e internacionais de Mark Monmonier, (How to lie with maps), para discutir as "mentiras" presentes nos mapas, e em Jacques Bertin, (Sémiologie Graphique), de modo a retratar as formas convencionais de comunicação cartográfica. A conclusão final da pesquisa aponta para uma gama de artifícios pictóricos com o intuito de estimular o imaginário dos visitantes e vender-Ihes tal fantasia em detrimento de emprego de variáveis visuais convencionais à cartografia. O que justifica esta ocorrência é o interesse de mercado de órgãos específicos, e a responsabilidade profissional de produção de mapas que é muitas vezes atribuída a sujeitos não qualificados para este exercício. É necessário nos preocuparmos com o rigor de produções científicas, como o instrumental cartográfico, visto que é visível a banalização que, muitas vezes, é atribuída a esta área do conhecimento, diante da facilidade de reprodução de imagens, via avanço tecnológico.

Palavras Chaves: Leitura e Representação de Paisagens, Cartografia Turística, Simbologia Gráfica. 


\begin{abstract}
This work is the result of a doctoral thesis held at the University of São Paulo, with the objective: "Examining thematic cartographic representation present in tourist maps for visitors in the municipality of Ponta Grossa-PR". This order came the problems observed in different uses symbolic maps offered to tourists, in different localities of the State of Paraná and even the country, creating a local image often not corresponding to the reality of cultural identity of these spaces. In the case of the municipality of Ponta Grossa - PR (Snip space chosen for study), tour focused on maps with great emphasis the Vila Velha State Park, leaving little depicted, or difficult location, other important sights: Hole of Priest, Mariquinha Waterfall, Green River Resort, Capão of ounce, Margharita Mazzine Park, Hilda Village, Saudade Station and many more. This allows somewhat condemn the municipality to a kind of extension of the State capital (Curitiba) within the itineraries pollute heavily this economic sector, and maculando of insignificant other potential natural and cultural sites. Thus, despite an overwhelming number of visitors who come to the city, these tourists virtually only comes to the Park and return, without visiting other areas and without even knowing the city. The rest is the lack of major public policies that promote a magnification in infrastructure access service, accommodation and even pivoting forward that could be a leap into the local sustainable tourism. In the development of search we use as working methodology of cartographic materials analysis (tourist maps) and interviews with users of the service (tourists and visitors locations), diagnosing the effectiveness of symbolic representation used in the two most up-to-date maps, correlating it to the causes and consequences of the outcome of such material produced as marketing tool, location and information. Also interviewed every responsible production of material to visitors, to learn their vocational training and criteria are considered important in the preparation of maps, as well as the heads of Department of tourism, to allow an understanding to the point of view, on the type of material contributed by doing a correlation with the quantitative data from previous research. Our studies are based, with priority to current theoretical conceptions and international Monmonier, Mark (how to lie with maps) to discuss the "lies" present on maps, and Jacques Bertin, (Sémiologie Graphique) to portray the conventional forms of cartographic communication. The final completion of the survey points to a range of pictorial artifice to stimulate the imagination of visitors and sell them this fantasy to the detriment of employment of conventional Visual variables to cartography. What justifies this occurrence is the interest of specific organs market and professional liability for the production of maps is often assigned to nonqualified for this exercise. You need to concern ourselves with the rigor of scientific productions such as instrumental cartographic, since it is visible to the banal, which is often assigned to this area of knowledge, given the ease of reproduction of images, via technological advance.
\end{abstract}

Keywords: Reading and Representation of Landscapes, Tourist Cartography, Graphical Symbology. 


\section{EI RESUMEN}

Este trabajo resultó de una tesis del doctorado en la universidad de São Paulo, con el objetivo de: "analizar la forma de la representación cartográfica temática existente en los mapas turísticos destinado a los visitantes en la ciudad de Ponta Grossa - PR". La intención viene al encuentro de la problemática que se observó en las varias aplicaciones simbólicas en mapas ofrecidos a turistas, en diferentes espacios del estado del Paraná y hasta del país, creando una imagen local que muchas veces no corresponde a realidad cultural y de identidad de estos respectivos espacios. En el caso de la ciudad de Ponta Grossa- PR (truncamiento elegido para el estudio), los mapas turísticos enfocan con gran énfasis el Parque Estadual de Vila Velha, olvidándose un poco o haciendo difícil la localización de otros puntos turísticos importantes como: Buraco do Padre, Cachoeira da Mariquinha, Rio Verde, Capão da Onça, Parque Margharita Mazzine, Vila Hilda, Estação da Saudade y otros más. Esto permite, de cierta forma, condenar la ciudad a una especie de la extensión de la Capital del Estado (Curitiba), dentro del guión turístico, penalizando con intensidad este sector económico, y manchando de insignificante otras potencialidades naturales y lugares culturales. Así, aunque un número expresivo de visitantes que viene hasta la ciudad, estos turistas comparecen prácticamente solo hasta el parque y vuelven ya, sin visitar demasiadas áreas o por lo menos conocer la ciudad. El resultado de esta indiferencia es el mayor desinterés de las políticas públicas que fomentan magnificar en las infraestructura de acceso, de atendimiento, alojamiento y hasta mismo de dinamización qué podría ser un salto para el turismo sostenible local. En el desarrollo de la investigación utilizamos como metodología del trabajo el análisis de los materiales cartográficos (mapas turísticos) y las entrevistas con los usuarios del servicio (los turistas y los visitantes locales), haciendo un diagnóstico de la eficacia de la representación simbólica usada en los dos mapas más actualizados, correlacionando esto a las causas y a las consecuencias del resultado del material producido como el instrumento de comercialización, localización y información. También fueran cuestionados los ciudadanos responsables por la producción del material de divulgación a los visitantes, para saber su formación profesional y los criterios que consideraban importante en la elaboración de los mapas, bien como los jefes del departamento del turismo, para permitir un entendimiento frente al punto de vista de los mismos, cuánto al tipo de material ofrecido, haciendo una correlación con los datos cuantitativos conseguidos en el campo de la investigación anterior. Nuestros estudios están basados con prioridad a los conceptos teóricos actuales e internacionales de Mark Monmonier, (Cómo usted miente con los mapas- How to lie with maps), para discutir "mentiras" presentes en los mapas, y Jacques Bertin, (Sémiologie Graphique), de manera a retratar las formas establecidas de la comprensión de la comunicación cartográfica. La conclusión final de la investigación señala con respecto a una gran cuantidad de artífices ilustrados con la intención de estimular el imaginario de los visitantes y vender tal suposición a ellos en el detrimento del trabajo de la variable convencional de la representación visual de la cartografía. Lo que justifica esta ocurrencia es el interés del mercado de agencias específicas, y la responsabilidad profesional de la producción de mapas que es muchas veces atribuidas a los ciudadanos no cualificados para este ejercicio. Es necesaria la preocupación con la rigidez de las producciones científicas, como el instrumento cartográfico, puesto que es visible la trivialización que muchas veces son atribuidas a esta área del conocimiento, delante de la sencillez de la reproducción de las imágenes, por medio del avance tecnológico.

Palabras llave: Lectura y Representación de Paisajes, Cartografía Turística, Simbología Gráfica. 


\section{LISTA DE MAPAS}

Mapa 1: Primeiro registro de representação cartográfica.....................................12

Mapa 2: Mapa turístico utilizando implantação pontual .......................................70

Mapa 3: Mapa turístico com exploração da implantação pontual e linear.............71

Mapa 4: : Mapa turístico com exploração pontual, linear e encartes de imagens.72

Mapa 5: Mapa turístico com exploração da implantação zonal .............................73

Mapas 6 e 7: Mapa turístico com encartes e hipertextos ........................................74

Mapa 8: Turismo de lazer também chamado de turismo de sol e praia.................76

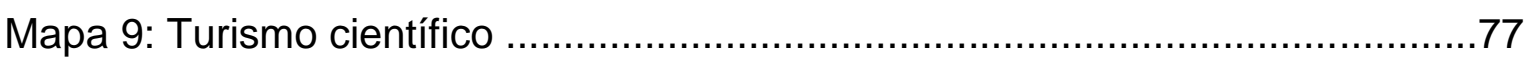

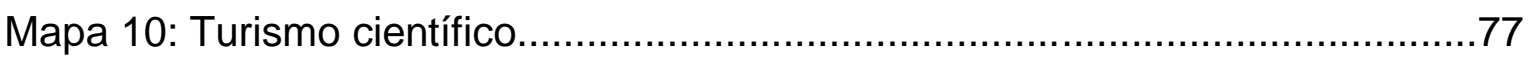

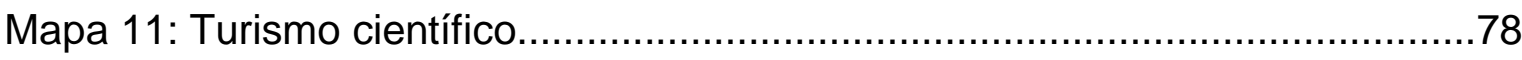

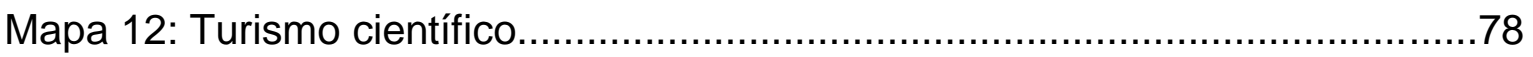

Mapa 13: Mapa com finalidade de ecoturismo ……….........................................79

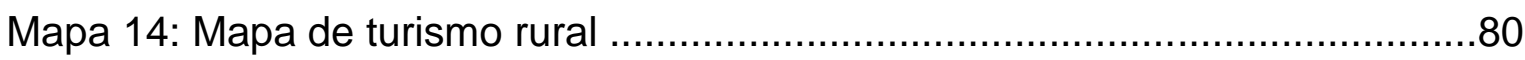

Mapa 15: Ponta Grossa - Localidades Turísticas...............................................94

Mapa 16: Oregon. Percepção de representação em diferentes escalas............108

Mapa 17: Mapa Turístico de Maringá.................................................................120

Mapa 18: Mapa Turístico de Foz do Iguaçu..........................................................122

Mapa 19: Mapa Turístico de Curitiba............................................................124

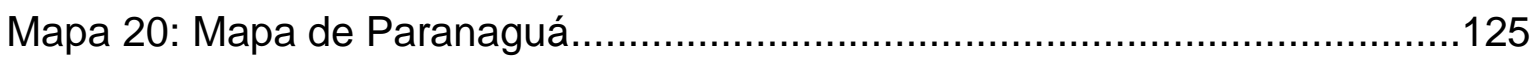

Mapa 21: Mapa Turístico de Ponta Grossa....................................................126

Mapa 24: Mapa de Localização de Ponta Grossa no Estado do Paraná.............151 
Mapa 25: Mapa de Localização de Ponta Grossa - Região dos Campos Gerais. 152

Mapa 26: Mapa Publicitário do "Centro de Ponta Grossa" 159

Mapa 27 e 28: Mapas turísticos antigos de Ponta Grossa..................................162

Mapa 29: Ponta Grossa - Um encontro de caminhos......................................164

Mapa 30: Mapa Turístico Ponta Grossa.........................................................165

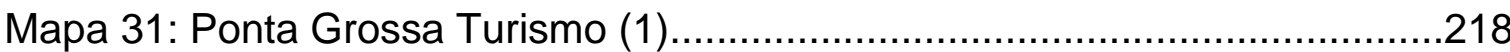

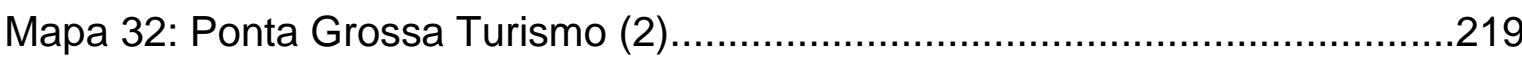

Mapa 33: Ponta Grossa Turismo nos Campos Gerais......................................220 


\section{LISTA DE FIGURAS}

Figura 1. Fotos de mapas antigos .34

Figura 2. Subdivisões Teórico-Metodológicas da Ciência Cartográfica .37

Figura 3. Exemplo de folder com mapa turístico - Curitiba 55

Figura 4. Fluxograma 1: A distribuição dos recursos turísticos............................56

Figura 5. Fluxograma 2: Modelo de comunicação na área do Turismo..................58

Figura 6. Fluxograma 3 : Sistema de informação-comunicação da Cartografia...60

Figura 7. Passos para o mapeamento temático..................................................63

Figura 8. Variáveis Visuais e Tipos de Implantação...........................................67

Figura 9. Horizonte ilustrativo utilizado em turismo científico ..............................77

Figura 10. Passos para elaboração de um mapa turístico.....................................81

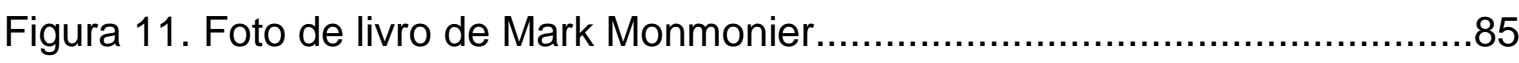

Figura 12. Selos argentinos, propagando a soberania da nação através de mapas ilustrativos .86

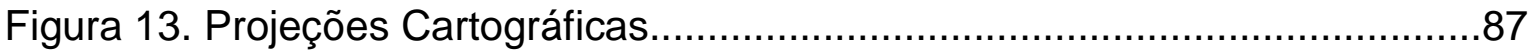

Figura 14. Mapa estratégico ilustrado em Jornal.................................................8

Figura 15. Transição de toponímias empregadas nos mapas...............................90

Figura 16. Satélites captando imagens da superfície terrestre............................97

Figura 17. Tipos de eventos realizados em Ponta Grossa.................................147

Figura 18. Exemplos de bilhetes descritivos das localidades turísticas...............166 


\section{LISTA DE GRÁFICOS}

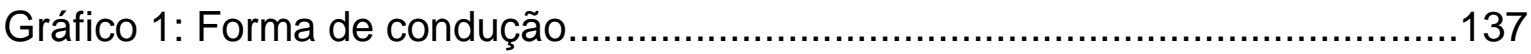

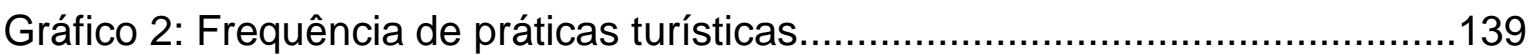

Gráfico 3: Lugares de interesse de visitação turística em Ponta Grossa.............145

Gráfico 4: Conhecimento das Potencialidades Turísticas..................................147

Gráfico 5 : Motivos que impedem visitações aos pontos turísticos......................148

Gráfico 6: Formas de localização espacial que os visitantes utilizam..................154

Gráfico 7: Considerações particulares sobre materiais cartográficos turísticos..156

Gráfico 8: Avaliação da preferência entre os dois materiais turísticos de Ponta

Grossa

Gráfico 9: Avaliação referente ao tamanho dos mapas....................................175

Gráfico 10: Avaliação referente à disposição dos dados nos mapas...................176

Gráfico 11: Avaliação referente ao tipo de ilustração........................................177

Gráfico 12: Avaliação referente à escala dos mapas.........................................178

Gráfico 13: Avaliação referente à legenda dos mapas.......................................179

Gráfico 14: Avaliação referente à forma de orientação presente nos mapas......180

Gráfico 15: Avaliação referente à variedade de tipos de síbolos nos mapas......181

Gráfico 16: Avaliação referente à cores empregadas nos mapas......................181

Gráfico 17: Avaliação referente ao tamanho das informações nos mapas...........182

Gráfico 18: Avaliação referente à quantidade de informações nos mapas..........183

Gráfico 19: Avaliação referente à síntese de informações nos mapas.................184

Gráfico 20: Avaliação referente à distribuição espacial dos dados no mapa.......185

Gráfico 21: Avaliação referente às informações de melhores vias de acesso.....186 
Gráfico 22: Avaliação referente à identificação dos lugares no mapa...

Gráfico 23: Avaliação referente à existência de legenda informando os tipos de turismo na temática do mapa.................................................................. 188 


\section{LISTA DE QUADROS}

Quadro 1. Comparativo entre as duas áreas da cartografia ............................40

Quadro 2. Visitantes dos principais atrativos do Paraná - visitantes/ano...........134

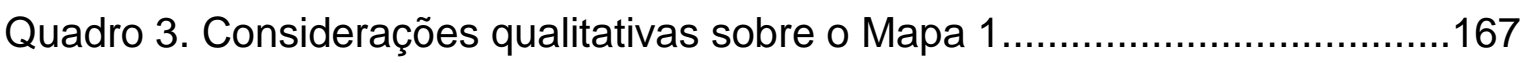

Quadro 4.Considerações qualitativas sobre o mapa $2 \ldots \ldots \ldots \ldots \ldots \ldots \ldots \ldots \ldots \ldots \ldots . . . \ldots 169$

Quadro A.1. Total de visitantes e distribuição por gênero................................208

Quadro A.2. Meios de condução utilizados para chegarem à visitação..............208

Quadro A.3. Faixa Etária dos Visitantes ................................................209

Quadro A.4. Cidades do Paraná que visitam Vila Velha.................................209

Quadro A.5. Estados do Brasil que visitam Vila Velha...................................210

Quadro A.6. Países que visitam Vila Velha.....................................................211 


\section{LISTA DE ABREVIATURAS}

ABNT - Associação Brasileira de Normas Técnicas

ALL - América Latina Logística

ARPPN - Área de Reserva Particular do Patrimônio Natural

EMBRATUR - Instituto Brasileiro de Turismo

IAP - Instituto Ambiental do Paraná

IBGE - Instituto Brasileiro de Geografia e Estatística

PNMT - Programa Nacional de Municipalização do Turismo

SIG - Sistema de Informação Geográfica 


\section{SUMÁRIO}

Página

INTRODUÇÃO

.20

CAPÍTULO 1. A CARTOGRAFIA: UMA CIÊNCIA E MUITAS APLICAÇÕES 31

1.1. A Cartografia Temática e seus códigos de linguagem 39

1.2. A Semiologia Gráfica e o Processo de Comunicação Cartográfica .43

1.3. A Geografia e a Cartografia relacionadas ao Turismo 46

1.3.1. A Cartografia aplicada ao Turismo 54

1.3.2. A produção de mapas voltados ao Turismo .59

1.3.3. As possibilidades de representação e leitura coerente 61

1.3.4. Tipos de Mapas Turísticos presentes no mercado .68

1.3.5. Passos para uma representação temática adequada ao turismo .80

\section{CAPÍTULO 2: ERROS E MENTIRAS CARTOGRÁFICAS} REVELADAS POR MONMONIER 84

2.1. Mark Monmonier e sua ampla abordagem teórica sobre cuidados cartográficos .85

2.1.1. O mapa enquanto símbolo de poder .85 
2.1.2. Os erros propositais e os erros acidentais em mapas .91

2.1.3. Tecnologias e Táticas no mundo da cartografia. .96

2.2. As distorções e desinformações encontradas em mapas 100

2.2.1. A escala grande na representação dos lugares e a omissão de referenciais de localização. 103

2.2.2. O efeito temporal e a necessidade de atualizações dos dados .....110 2.2.3. Símbolos, Cores e Imagens: Atrações e distrações em prol do explorar o imaginário 112

2.3. Mapas para fins de propaganda. 115

CAPÍTULO 3:O CONCRETO PENSADO TURÍSTICO NO UNIVERSO

DA PESQUISA GEOCARTOGRÁFICA 117

3.1. Os Procedimentos Metodológicos de Investigação .117

3.1.1. A pesquisa de Campo Prévia e as Coletas de Dados Diversos .....119

3.1.2. O Método Quantitativo e a Estatística Descritiva.........................127

3.1.2. Estrutura do Questionário: Perguntas Abertas e Fechadas.......... 129

3.1.3. Definições estatísticas, distribuição de freqüências e tipos de variáveis. 131

3.2. Os Resultados da Pesquisa. 133

3.2.1. O Município e seu perfil geoturístico 151

3.2.2. A política pública interna voltada ao turismo. .153

3.2.3. Uma Cartofobia coletiva? 155 
3.2.4. . Aprofundando a investigação sobre a qualidade dos mapas

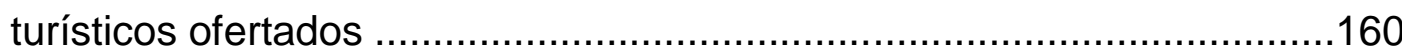

3.2.5. Análise quantitativa sobre os mapas avaliados.............................175

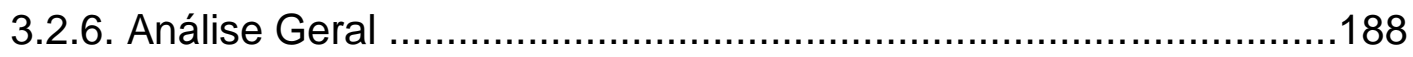

CONCLUSÃO:

REFERÊNCIAS BIBLIOGRÁFICAS...........................................199

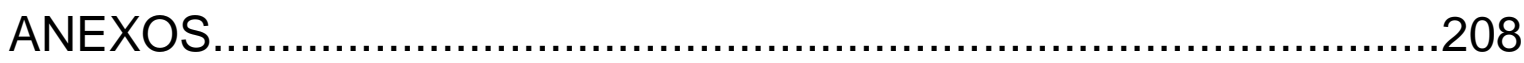

ANEXO 1. Dados pesquisados sobre perfil dos visitantes no Parque Estadual de

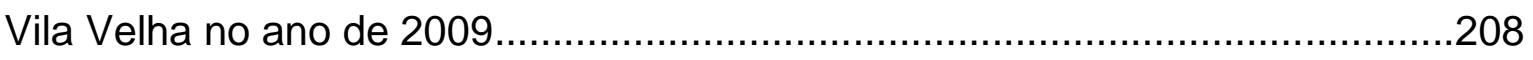

ANEXO 2. Autorização do IAP para realização de pesquisa no Parque Estadual de Vila Velha

ANEXO 3. Material de Pesquisa de Campo - Questionário ...............................213

ANEXO 4. Material 1. Utilizado para Análise dos Entrevistados ........................218

ANEXO 5. Material 2. Utilizado para Análise dos Entrevistados.......................219

ANEXO 6. Ponta Grossa nos Campos Gerais - Aspectos Turísticos..................220 


\section{INTRODUÇÃO}

Este presente material tem como propósito apresentar a pesquisa realizada como Tese de Doutorado nesta instituição, a Universidade de São Paulo, junto a Faculdade de Filosofia, Letras e Ciências Humanas, Secretaria de PósGraduação em Geografia, sob a orientação da Professora Doutora Maria Elena Ramos Simielli.

Temos como temática as "representações cartográficas destinadas ao turista", e para isso escolhemos como título da pesquisa: "CARTOGRAFIA TURÍSTICA: Uma Leitura dos Mapas Temáticos de Uso do Turista em Ponta Grossa - Paraná"

A pesquisa tem por finalidade retratar as questões teóricas, técnicas e, porque não dizer, ideológicas, que giram em torno da Cartografia na sua função de elaboração de mapas, seja ela diretamente ligadas a esta ciência enquanto produtora principal de mapas, ou seja, através de outras áreas coirmãs, que se utilizam dessa ciência e também manipulam a técnica de produção de material cartográfico, como no caso que enfatizaremos, a área do turismo.

\section{DELIMITAÇÃO DO PROBLEMA}

Sabemos que não apenas a área da geografia, mas também inúmeras outras ciências e áreas técnicas têm a necessidade de se utilizar desse 
instrumento de materialização da espacialidade, o mapa, para ser tratado numa pesquisa ou em determinado trabalho. Poderíamos até dizer que o uso do mapa hoje já é uma necessidade cotidiana de todos, estudiosos ou leigos. No caso da situação do uso do mapa para o turismo, este recebe diferentes conotações; assim, teremos mapas do serviço de turismo, ofertado em determinadas espacialidades, mapas para o planejador e gestor do turismo, e mapas para o turista, usuário do serviço.

Foi pensando nisso e também observando situações de conflitos em mapas mal elaborados, ou mapas errôneos (situações distintas uma da outra), que passamos a nos preocupar com o aspecto simbólico da produção de mapas, uma vez que este pode ser instrumento de verdades ou mentiras transmitidas a toda população.

Entre as situações mais polêmicas no decorrer da história, citamos erros propositais, símbolos e ícones tidos como mentiras e/ou mitos em mapas, alguns com finalidades políticas de tomada de territórios e até em mapas militares, que muitas vezes foram também destinados a este fim, a distorção de informações.

$\mathrm{Na}$ atualidade, os mapas mais errôneos (com distorções propositais, os quais foram atribuídos aqui, atrelados ao conceito de "mentira") são os chamados de mapas promocionais, utilizados com efeitos de propaganda: imobiliária, turística, eleitoral, ambiental, empresarial e outros, sendo os ligados à especialidade turística, os que serão utilizados por nós para efetivar tal pesquisa, por ser um dos casos mais frequentes em retratar distorções de ordens diversas.

\section{OBJETIVOS}


Diante de nossa problemática, temos:

A. OBJETIVO GERAL: Analisar a forma de representação cartográfica temática presente nos mapas turísticos destinados aos visitantes no Município de Ponta Grossa - PR.

B. OBJETIVOS ESPECÍFICOS:

1. Ilustrar os tipos de manifestações simbólicas que se utilizam em um mapa formal, na concepção da cartografia temática;

2. Identificar situações em que a linguagem cartográfica pode e/ou não pode direcionar o usuário do mapa às leituras errôneas da realidade;

3. Refletir sobre a origem (fonte) das produções dos mapas turísticos no Município de Ponta Grossa - Paraná.

4. Investigar a repercussão dos mapas turísticos "errôneos" para os usuários desse serviço turístico pontagrossense.

5. Apontar direcionamentos importantes a serem considerados nas novas produções de mapas a serem oferecidos ao turista.

Acreditamos que tais objetivos possam ser atingidos partindo de muita consulta bibliográfica do que vem sendo discutido no âmbito do conhecimento ocidental especializado nas áreas da Cartografia e Geografia, com os autores 
elencados para a pesquisa, além de reflexões pertinentes inseridas no contexto pesquisado, o turismo.

\section{JUSTIFICATIVA E IMPORTÂNCIA DO TEMA}

O tema em questão é uma proposta de discussão sobre a ciência cartográfica que é de fundamental importância para a Geografia, uma vez que se caracteriza como instrumental de uso da sociedade em geral, e que, em muitos casos, tem sido utilizado no decorrer da história, com distorções para ocultar segredos, com intuitos de má fé, ou ainda, numa vulgarização (banalização) de seu real valor, tratando-o como um mero trabalho artístico. Haja vista que, LACOSTE em seu livro "A Geografia - Isso Serve Antes de Mais Nada, para Fazer a Guerra", fala da importância de se conhecer o espaço para saber nele se organizar, associando este domínio do conhecimento espacial, do saber geográfico e cartográfico com o poder da sociedade, como uma ferramenta de dominação ou alienação.

Se buscarmos a história das civilizações, das grandes navegações, da formação dos impérios, veremos a vital importância do mapa para os detentores do poder, tanto que estes mapas eram tidos como verdadeiros tesouros de Estado, e, desde esta época, já eram divulgadas produções falsas, com propósitos errôneos para a maioria da população, de modo a não permiti-las ter o contato com a verdade. 
O trabalho que ora apresentamos, vem discutir não somente a importância de trabalhar corretamente com o mapa temático (produção e leitura de tal documento através do conhecimento da Semiologia Gráfica e demais itens indispensáveis), mas também analisar as reais informações que estão sendo representadas, ou ainda, refletir sobre a leitura daquilo que não está representado diretamente no mapa, mas que carrega em seu arcabouço. Torna-se, portanto, indispensável que todos, profissionais e leigos, saibam ler um mapa em sua

totalidade (aparente e camuflada), para assim conseguir compreender a complexidade que envolve a Cartografia, a ciência geográfica, ou ainda, a própria realidade vivida.

\section{BASES TEÓRICAS E METODOLÓGICAS}

Para abordar essa temática elegemos como suporte Mark Monmonier, entre outros sem menor importância, que citamos no corpo do trabalho, como Harley, Slocum, MacEachren, Wood e Fels.

Jacques Bertin será também um dos autores mais discutidos no âmbito das simbologias, devido ao seu estudo "Semiologie Graphique" (Semiologia Gráfica), extremamente essencial para as representações de ordem temática.

Quanto à escolha por Monmonier, se justifica porque este traz discussões acerca das questões de verdade e mentira em mapas, sendo que entre tantas consequências oriundas da má utilização deste instrumento, destacam até 
mesmo a origem de uma patologia problematizadora, denominada "Cartofobia", que iremos abordar na especificidade do mapa turístico.

Nossa pesquisa procurará refletir sobre estas questões, apresentando situações concretas que serão analisadas, à luz de teóricos renomados da Cartografia, de modo a contribuir para a Ciência Geográfica que utiliza deste instrumental, o mapa, para abordar as suas categorias particulares que se referem às questões de organização espacial: paisagem, lugar, região e território.

O contexto dos mapas turísticos está inserido entre os demais no estudo destas categorias geográficas e, nesse sentido, não pode ficar aquém das responsabilidades científicas e sociais que devem estar presentes no pensar e agir de profissionais atuantes na área.

No Brasil, adotamos como referência Marcelo Martinelli em especial, entre outros referenciados para abordarmos a questão da Cartografia Temática; destacamos Gisele Girardi em algumas citações com relação especial às questões do "mito", Eduardo P. Girardi da Cartografia Geográfica, fazendo uma crítica sobre o pensar geográfico na elaboração de mapas, bem como Lindon F. Matias que desenrola esta mesma crítica ao uso do SIG, que é um instrumento de

\footnotetext{
${ }^{1}$ Numa crônica portuguesa de traço irônico, encontramos a denominação do termo Cartofobia como sendo a síndrome que ataca os seus habitantes, especialmente em períodos festivos e de veraneio, quando os mesmos se deslocam de suas residências em destino à lugares turísticos. Logo, tal patologia decorrente do repúdio ao mapa, causa extremo estado de irritação e estresse, e atinge a grande maioria da população, sendo que as mais leigas são as principais vítimas. Os autores da crônica explicam que os turistas quando saem de suas casas para se dirigirem à visitação de outro lugar com a perspectiva prazerosa do lazer, ou de conhecer algo novo, acabam se deparando com o transtorno de não conseguirem fazer uso do material cartográfico, pois se vêem impossibilitados de chegar à localidades através de consulta aos mapas turísticos, isto porque não conseguem efetuar a leitura necessária, face aos tantos artifícios rebuscados que tais mapas utilizam, tornando-os pouco eficazes. Assim, tornam-se céticos, desacreditados de encontrar nesse recurso, o mapa, um apoio para sua localização, ou seja, concebendo-os como inúteis, devido ao nervosismo que passam diante do material que não proporciona a facilidade de uso; isso caracteriza o desenvolvimento da tal Cartofobia.
} 
uso cartográfico nas últimas décadas. Tais autores que elencamos como principais bases conceituais de nossas discussões são bastante atuais (a partir da década de 80), e seus estudos recentes e resultantes desse momento de grande avanço da tecnologia, que tem repercutido num verdadeiro expansionismo da indústria de mapas com finalidades diversas, ou seja, da Cartografia Temática.

Compreendemos que as correntes epistemológicas, como em toda pesquisa científica, contribuem no sentido que são ferramentas de convicção. São elas que propiciam a aceitação de uma afirmação e certa evidência de sua relevância tida como verdade aceita, embora saibamos que a ciência não é "dona" da verdade; toda "verdade" científica tem um caráter probabilístico. (RICHARDSON 1999; 18).

Conforme afirma ainda Roberto J. Richardson:

“... dita atitude do pesquisador exige reorganização do conceito de saber, nova visão que permita reconhecer a incerteza, falta de clareza, relatividade, instrumentalização e ambigüidade do conceito "verdade científica". Essa posição pode levar a importantes avanços na produção e democratização do saber, muito mais que a simples aceitação não questionada, do que aparece nos livros e mentes dos especialistas." $(1999 ; 18)$.

Para desenvolver a pesquisa como um todo, tomamos como caminho metodológico além dos estudos teóricos, a análise documental (mapas e folders turísticos) e entrevistas semi-estruturadas. 


\section{RECORTE ESPAÇO-TEMPORAL}

Sabendo da acusação crítica de superficialidade sob situações em que se utilizam da totalidade enquanto espaço a ser investigado, entendemos que não se tem como restringir a ocorrência de determinados fenômenos problemáticos para um espaço específico, uma vez que há uma característica de existência praticamente histórica desta situação diante da ciência tratada: a Cartografia.

As lentes de visão do nosso problema focarão, em alguns momentos, diferentes situações em que se manifestam a mentira no mapa, em diferentes espacialidades e datas, porém dentro do contexto atual que elencamos, ou seja, meados dos Séculos XX e início do século XXI. Entretanto, as investigações e testes desenvolvidos foram aplicados no Município de Ponta Grossa - Paraná, município onde residimos e atuamos profissionalmente, nos anos de 2008 a 2010, pois precisávamos então traçar um recorte espacial para a pesquisa específica sobre o concreto vivido. Este era bastante interessante por estar entre as maiores potencialidades turísticas do Estado bem como para ser posteriormente utilizado e dar mais visibilidade a esta temática, em trabalhos de campo e aulas teóricas e laboratoriais, na Universidade Estadual (UEPG), em que atuamos como docente e pesquisadora do curso de Geografia.

\section{DISTRIBUIÇÃO DO TRABALHO}


Diante de tais interesses, iremos dispor o desenvolvimento do trabalho em três capítulos, apresentando toda a dinâmica e arcabouço de nossa pesquisa:

CAPÍTULO 1. A Cartografia: Uma Ciência e Muitas Aplicações. Neste capítulo traremos uma sinopse sobre a Cartografia Ocidental e seus códigos e linguagens, principalmente a partir do século XX. Paralelamente discutiremos a relação entre a Geografia e o Turismo, e principalmente destes com a Cartografia, onde nos reportaremos a algumas abordagens sobre o setor do turismo em seus diferentes aspectos: acadêmico, político e gestorial, e de consumo, de modo a permitir correlacionar os diferentes tipos de mapas voltados ao turismo, às preocupações com seus códigos de linguagem a serem utilizados de forma correta e suas possibilidades de leitura coerente, e, ainda, a importância dada ao profissional produtor de mapas voltados ao uso no turismo.

\section{CAPÍTULO 2. Erros e Mentiras Cartográficas Reveladas por Monmonier.} Neste capítulo nos reportaremos a toda visão de Monmonier sobre cuidados cartográficos, a sua vinculação enquanto símbolo de poder e a serviço de uma ideologia, os erros mais frequentes, a contribuição e consequências do avanço tecnológico, e as características de um mapa com o interesse promocional ou de propaganda. 


\section{CAPÍTULO 3: O Concreto Pensado Turístico no Universo da Pesquisa}

Geocartográfica. Onde traremos com detalhe todos os procedimentos metodológicos de investigação e os resultados da pesquisa. Explicaremos aqui o porquê de nossas escolhas metodológicas e procedimentais, bem como detalharemos sobre as diretrizes norteadoras pré-estabelecidas, e retrataremos os resultados que obtivemos em tais investigações. Finalizando apresentaremos tais resultados dentro de nossas considerações diante de um profundo refletir teórico que nos propusemos a realizar e debruçados em fatos concretos de nossa localidade delimitada e analisada, de modo que possamos traçar uma discussão conclusiva sobre tal arcabouço que está por detrás de cada um desses mapas.

No transcorrer de nossa análise de dados traçamos um paralelo com a investigação teórica, norteando algumas diretrizes para estabelecer nossa reflexão conclusiva a ser comentada nas considerações finais.

- Verdade X Mentira no âmbito científico

Apesar de haver uma grande relatividade no que tange à "verdade" científica, não podemos deixar de nos referir ao que consideramos ser uma "mentira".

- Erro proposital X Incapacidade Técnica

Mentira é diferente de erro, porém veremos que mentira pode ser chamada de erro proposital quando o sujeito que atua sobre determinada questão, tem plena consciência do propósito de distorção dos fatos e, consequentemente da informação a ser transmitida. Já a capacidade técnica diz respeito à falta de formação profissional de quem tem operado neste campo, sem portar qualquer preparo e principalmente domínio dos princípios essenciais da ciência 
cartográfica. Neste caso também ocorrem erros, muitas vezes imperceptíveis aos olhos de alguns, e até mesmo do seu produtor.

- Interesse Mercadológico X Responsabilidade Social do Profissional

O Paralelo entre interesse mercadológico e responsabilidade profissional gera uma discussão acerca da responsabilidade do profissional atuante com a cartografia e demais ciências, visto que, muitas vezes, se colocado a favor do mercado das propagandas, apresentando um falseamento do material produzido, está faltando não só com a sua eficácia profissional, mas também com sua responsabilidade social.

Tais diretrizes serão, portanto, em nosso pensar, um fio condutor para chegarmos às nossas considerações sobre a análise final.

Acreditamos que, nossa preocupação em tornar a leitura desse trabalho, bastante fácil e de clara compreensão, estará sendo atendida, na medida em que buscamos ser coesos e ao mesmo tempo lógicos com o nosso referencial teórico que está diretamente amarrado em nossos objetivos propostos, bem como detalhamos através de referências as possíveis dúvidas quanto às nossas apresentações e argumentações. 


\section{CAPÍTULO 1.}

\section{A CARTOGRAFIA.}

\section{UMA CIÊNCIA E MUITAS APLICAÇÕES}

"Quando imaginamos que já decoramos todos os mapas, vem a tempestade humana, que muda e reinventa toda a Geografia"

(reformulado de autor desconhecido)

Vários são os conceitos de Cartografia, de acordo com cada autor e época. De modo bem sucinto Joly $(1990 ; 7)$ afirma que "Cartografia é a arte de conceber, de levantar, de redigir e de divulgar mapas". Teixeira \& Christofoletti $(1997 ; 55)$ citam em seu dicionário ilustrado, um conceito mais rebuscado, voltado a era digital contemporânea, quando narram que, "Cartografia é a ciência cujo objeto é organizar, apresentar e utilizar a informação geográfica nas formas visual, digital ou táctil, incluindo todos os processos de aquisição, preparação e apresentação de dados".

Para evitar uma exemplificação excessiva, apresentamos a definição que para nós não é nem neutra na cientificidade e nem artificializada pelo modernismo, mas certamente uma das conceituações mais completas e lógicas: 
do tempo de forma generalizada. (SALICHTCHEV, 1973; 10 apud MARTINELLI, 1991; 3).

As representações cartográficas do espaço geográfico podem ser feitas através de mapas, cartas, plantas, globos, imagens de satélites, gráficos, perfis topográficos, croquis, dentre outros, sendo bastante comum também chamar de mapas as cartas, plantas e croquis (embora estas outras representações sendo em escala maiores).

Os primeiros mapas datam de muito tempo, a mais de 2.000 anos antes de Cristo, sendo um dos mais divulgados, o mapa em pedra, registrando a região do vale do Ga-Sur ${ }^{2}$, podendo este ser visualizado na ilustração que temos a seguir.

MAPA 1: Primeiro registro de representação cartográfica.

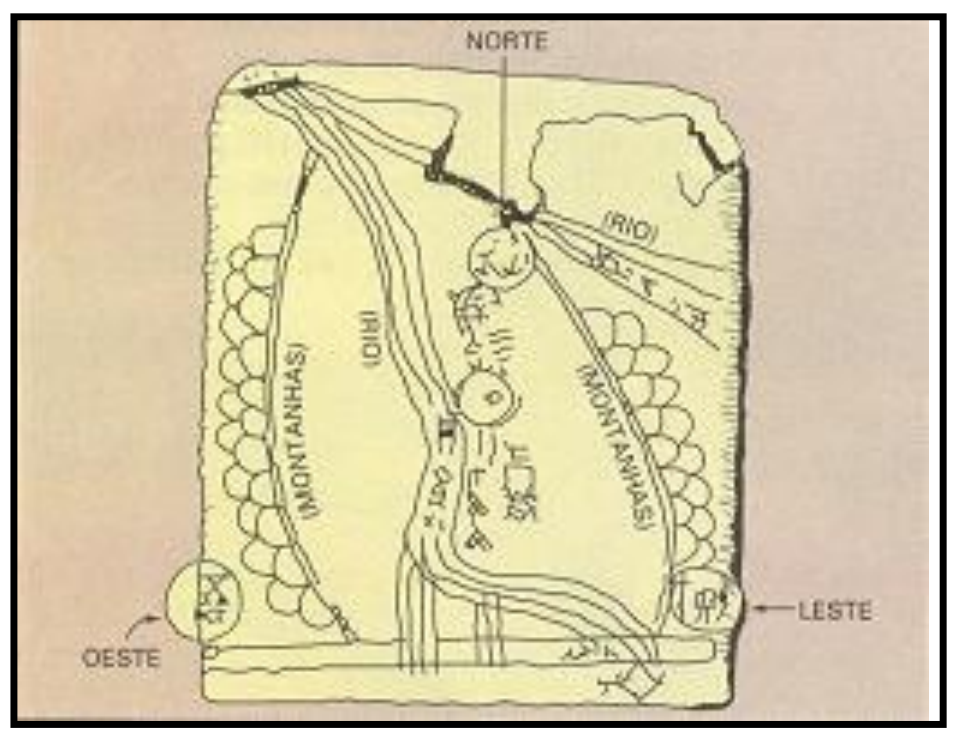

Fonte: http://www.pead.faced.ufrgs.br/sites/publico/../e2a6b 1. htm

\footnotetext{
${ }^{2}$ Este mapa de Ga-Sur, região da Mesopotâmia é datado de 2500 a.C., sendo o mapa mais antigo que se tem conhecimento. Não apresenta qualquer convenção como título, escala ou legenda. Suas referências são diretamente destacadas no desenho e aqui foram traduzidas para facilitar a identificação simbólica.
} 
Desta época até os dias atuais foram inúmeros os aprimoramentos que esta área científica, a Cartografia, foi conquistando, acompanhando o desenvolvimento da história com inúmeras invenções que vinha de encontro aos seus propósitos trazendo muito enriquecimento ao seu método. Entre os acontecimentos de grande contribuição podemos citar as invenções: do papel, da imprensa, dos instrumentos de medição e posteriormente dos meios tecnológicos informatizados.

Vargas e Garcia narram:

\begin{abstract}
Um dos aspectos mais interessantes na compreensão dos velhos mapas, dos parietais aos de bolso, é o de estudar a sua leitura e os seus leitores, os coevos e os que ao longo dos séculos voltaram a observar e interpretar as mesmas históricas imagens. O que leram como leram e porque leram aqueles documentos tão particulares e únicos, quer os que com eles reconheceram, organizaram e dominaram o espaço, quer os simples curiosos do mundo? (2005-2006-2007; 11).
\end{abstract}

Vargas e Garcia, afirmam ainda nesta explanação histórica que: "Em geral, os mapas eram fruto da intervenção do Estado sobre o espaço, e das economias privadas desenvolvidas para o conhecimento do território e a exploração dos recursos naturais". (2005-2006-2007; 14).

Alguns exemplos deste tipo de mapas antigos, com grande valorização ao território, como expressão do poder, podem ser observados na sequência, onde demonstramos diferentes mapas urbanos, de localidades distintas: 
Figura 1: Fotos de mapas antigos

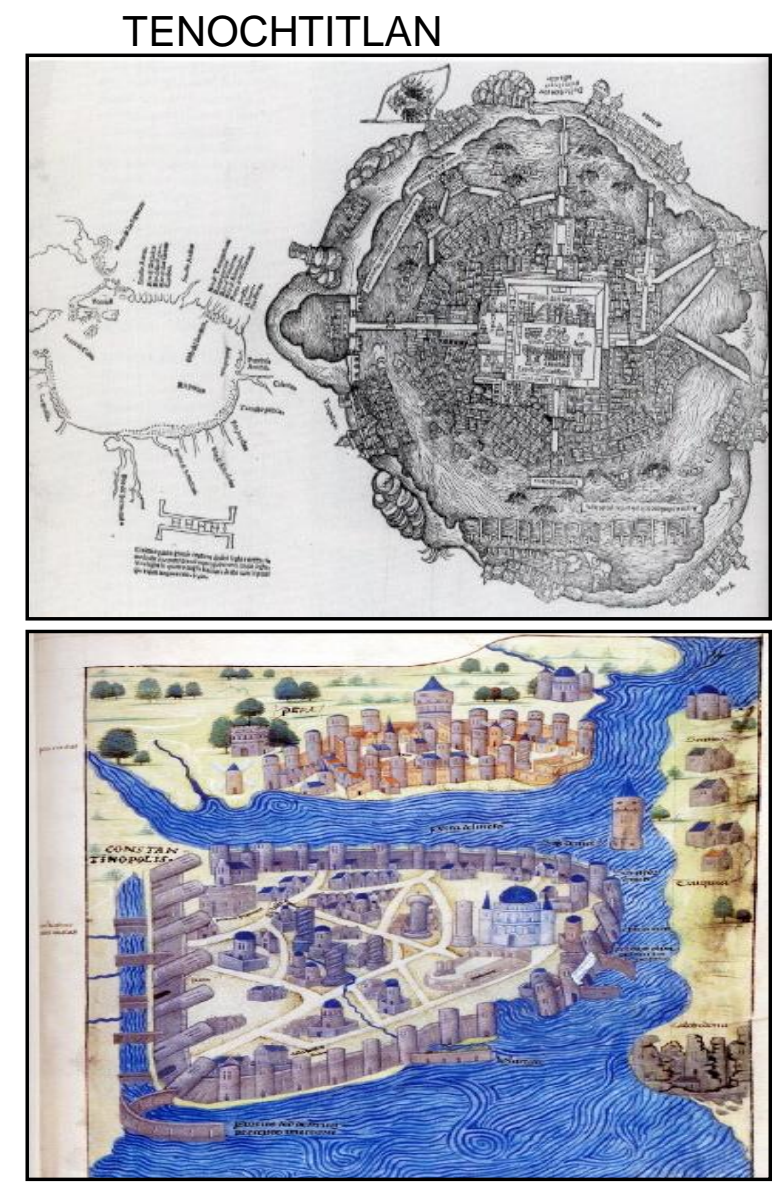

CONSTANTINOPLA
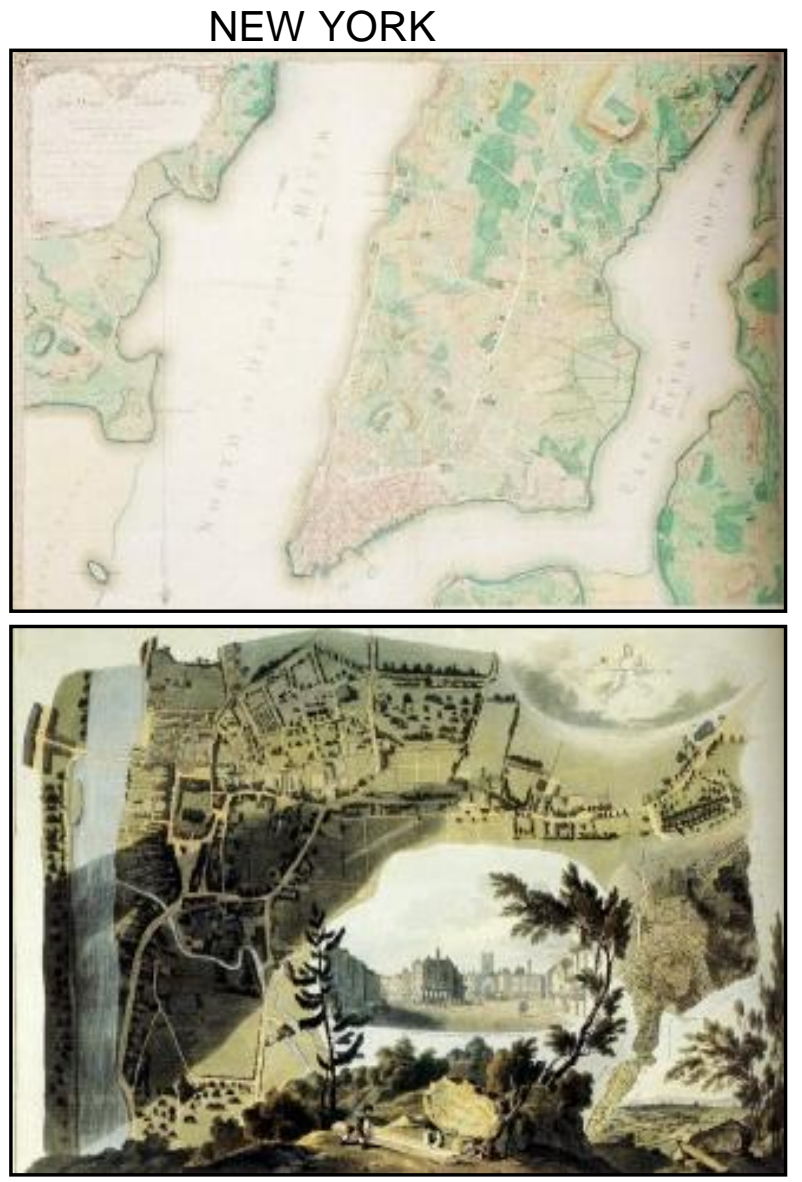

KINGSTON

Fonte: ELLIOT, James. THE CITY IN MAPS: URBAN MAPPING TO 1900.London: The British Library Board, 1987.

Percebemos com isso que, também os propósitos pragmáticos apresentaram grandes transformações, servindo primeiramente aos registros de territórios descobertos nos tempo primórdios, depois servindo aos interesses coloniais de expansionismo do império, mercantilístico com o comércio marítimo, político de controle militar e descritivo do território tanto com ênfase qualitativa como quantitativa. 
Hoje, os mapas servem aos mais diferentes propósitos, pois com o desdobramento da Cartografia Temática e a elaboração de mapas específicos sobre geologia, meteorologia, demografia, industrialização, entre outros temas completamente inimagináveis, podem atender a quaisquer problemáticas específicas que tenham a necessidade de representação espacial.

O Geógrafo inglês Brian Harley ${ }^{3}$ (1989) se destacou na Cartografia como um dos estudiosos que se dedicou com afinco às pesquisas sobre essa história da ciência cartográfica, sendo um dos teóricos que mais influenciaram em seu processo de renovação, tanto como objeto de pesquisa como em atividades independentes. Tal contribuição foi imbuída de uma exploração epistemológica e também metodológica que permitiu checar outras áreas correlatas, num olhar interdisciplinar fazendo um balanço histórico das mais diversas outras explorações feitas até então.

A epistemologia dos mapas traduz a evolução do pensamento humano ocidental, rumo ao saber pragmático e científico. Cientificamente, estudiosos como Harley (1989), Wood \& Fels (1992), Woodward (1998) e outros, atribuem a sistematização da Cartografia ao século XIX, junto com as demais ciências, em especial a Geografia, que tem uma ligação muito íntima com esta ciência da representação espacial. Nesta época a Cartografia era primordial para a ciência geográfica, que respaldou, no final deste século, suas raízes na escola regional, com La Blache (MORAES, 1984). Através das imagens cartográficas, a Geografia

\footnotetext{
${ }^{3}$ Talvez a maior contribuição de HARLEY, que fez dele um inspirador de tantos outros seguidores foi o seu caráter crítico de olhar para os mapas. Para ele a preocupação maior não se concentrava na produção técnica do mapa, mais sim e principalmente no juízo de valor que tal documento repassava aos seus usuários.
} 
constituía-se método de análise, utilizando-se não apenas do registro em si, mas também da síntese obtida de informações sobrepostas nestes mapas.

Harley (1987) destaca que fora imprescindível para a ampliação dos estudos cartográficos a institucionalização da Geografia enquanto ciência, os acervos bibliográficos especializados em mapas antigos e a contribuição particular de estudiosos e colecionadores, isto tudo particularmente após a segunda metade do século XIX. Foi neste século que surgiu a divisão da Cartografia em: Cartografia Topográfica e Cartografia Temática e também foi nessa época inclusive que disseminaram os $\mathrm{Atlas}^{4}$, com mapas sobre as mais variáveis temáticas, até mesmo de passagens da Bíblia.

No século $X X$, se deu o maior aprimoramento técnico na área, que passou a buscar execuções bem mais pragmáticas, conforme se sucedia também na Geografia. A ciência cartográfica assistiu também um avanço em suas bases

\footnotetext{
${ }^{4}$ Segundo Black (2005; 92):
}

O século 19 foi o século no qual o atlas histórico se estabeleceu firmemente na cena europeia. Esse desenvolvimento refletia vários fatores, que podem ser resumidos como expulsão e atração, oferta e procura. Mapas confiáveis ficavam mais fáceis de oferecer e publicar. A maior parte do mundo fora mapeada, e as fronteiras políticas da Europa, e de modo crescente do mundo político europeu como um todo, eram agora precisas. A impressão de cores se tornou mais fácil, e assim mais informações podiam ser apresentadas. Como mais atlas históricos eram produzidos, também um fundo crescente de informações para obras adicionais foi criado.

Mudanças tecnológicas eram de grande consequência. A confecção mecanizada de papel tornou-se comercialmente viável na década de 1800, levando à produção, com energia a vapor, de grandes quantidades de papel que não era caro, e a prensa tipográfica movida a vapor desenvolveu-se no mesmo período. Embora não houvesse progressos significativos na composição tipográfica até a década de 1800 , essas mudanças criaram um público potencial muito mais amplo para o cartógrafo e asseguraram que a cartografia tivesse de se adaptar ao desafio. Numerosos mapas tiveram de ser produzidos, suas especificações tinham de ser apropriadas e, era necessário assegurar que um novo público leitor estivesse interessado em mapas e fosse letrado em cartografia. 
teórico-metodológicas, especialmente na Cartografia Temática através das correntes de estudo da informação, modelização, semiologia gráfica, cognição, e visualização cartográfica, expressas na figura a seguir.

Figura 2: Subdivisões Teórico-Metodológicas da Ciência Cartográfica

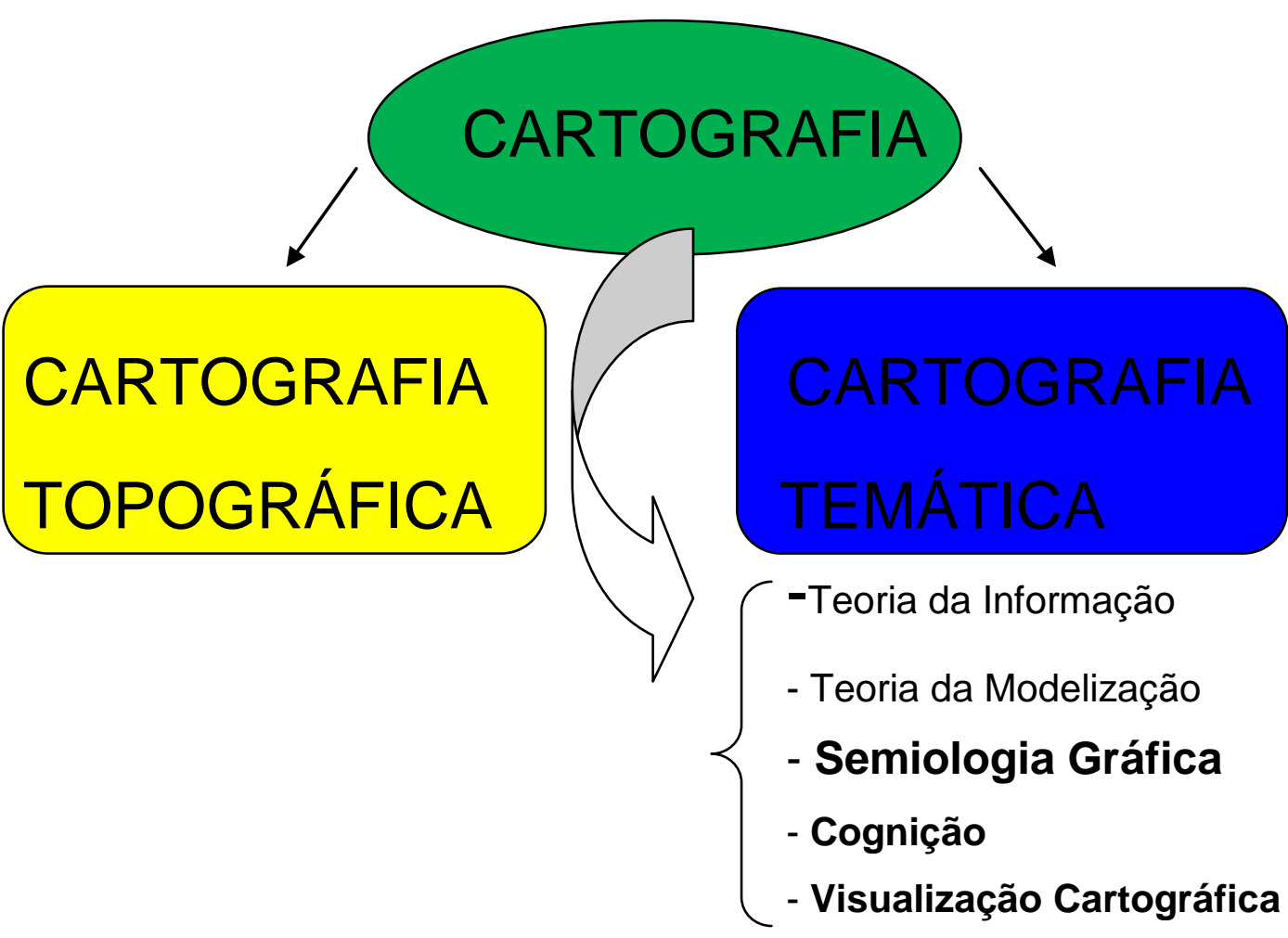

Fonte: ULLER, A. S. 2010.

Na segunda metade do século, a Cartografia se beneficiou muito com o avanço tecnológico que o mundo vivenciou após a chamada corrida armamentista. Os equipamentos espaciais foram incorporando fotografias aéreas e sensores que contribuíram grandiosamente para o aperfeiçoamento dos processos de mapeamentos, com o surgimento de áreas especializadas em fotogrametria e sensoriamento remoto. 
O processo de informatização do mundo alcançou a Cartografia na década de 90 e, com isso, incorporou uma nova área, o Sistema de Informação Geográfica (SIG) que permite uma agilidade muito maior no processo de mapeamento e análise interpretativa, pois, congrega a imagem ou mapa, junto a um banco de dados, que servem para uma infinidade de ações que resultam na finalização de mapas temáticos, conforme programação.

Portanto, para a Geografia, aprender Cartografia é aprender as normas utilizadas na construção de mapas, as diferenças entre um mapa e outro, o uso de cada tipo de produto gráfico, e, no contexto atual, o emprego da tecnologia cartográfica, que são as diversas técnicas computadorizadas que permitem através de equipamentos diversos, uma maior precisão na obtenção de imagens e seus dados referenciais.

Se os meios técnicos avançaram facilitando o processo de mapeamento, por sua vez, a mente humana não pode mais ser concebida como uma "caixa preta", afinal "hoje, os cartógrafos tem uma perspectiva cognitiva, na qual eles esperam para saber por que os símbolos trabalham de forma eficaz" (tradução de SLOCUM; 2010,02).

Antes a preocupação estava em obter recursos técnicos que facilitassem o processo de mapeamento e trouxesse maior exatidão, hoje a reflexão crítica está mais cunhada no uso pragmático desse suporte, pois há duas décadas, já temos um potencial bastante grande para a operação de produção de mapas, no entanto, o que isso tem contribuído para a ciência e principalmente para a sociedade em geral? Será que estamos sabendo utilizá-los e também analisá-los criticamente para o que estão servindo? É nesse sentido que tais pesquisas 
corroboram de modo importantíssimo para os cursos superiores, responsáveis em grau mais elevado para a formação do cidadão que irá produzir e utilizar tais mapas.

Não há dúvidas quanto ao imenso leque de possibilidades que o avanço tecnológico trouxe para a ciência, porém precisamos analisar se o uso deste potencial tem sido feito de forma correta. Se antes era difícil elaborar um mapa, ou ter acesso a um, hoje isso se faz quase em tempo real, com a democratização de imagens através da internet, bem como a participação dos sujeitos em mapas interativos, fazendo-os trabalhar, cada qual, para um interesse em particular de visualização.

Diante do histórico científico que apresentamos sucintamente, queremos ressaltar que nosso foco de pesquisa está na Cartografia Temática, desenvolvida no Ocidente e no contexto atual, ou diríamos, nesta transição entre os séculos XX e XXI, após o emprego da informatização, e, isso é o que passamos a tratar a partir desse momento.

\subsection{A Cartografia Temática e seus códigos de linguagem}

Como foi mencionado, a Cartografia não é uma área recente, no entanto, a mesma apresenta diferentes propósitos, podendo estes ser de ordem universal (geral) ou específica (particular). Para isso se convencionou a divisão em duas áreas: Cartografia de Base ou Topográfica (mais genérica) e a Cartografia 
Temática (específica). Oportunizamos aqui lembrar que a cartografia temática não surge de forma espontânea, ela foi historicamente sucessiva à visão topográfica do mundo, construída essencialmente de forma analógica. (MARTINELLI, 2003)

A seguir, podemos observar através do quadro, um comparativo bastante resumido entre as duas Cartografias, nele é possível constatar as aproximações e diferenças.

Quadro 1: Comparativo entre as duas áreas da cartografia

\begin{tabular}{|l|l|}
\hline * Cartografia de Base: & Cartografia Temática \\
\hline $\begin{array}{l}\text { 1. Servem a uma típica e ao mesmo tempo } \\
\text { ampla clientela, portanto, a uma grande } \\
\text { diversidade de propósitos. Tendem a divulgar } \\
\text { fatos relacionados com características físicas } \\
\text { da superfície terrestre. Os limites políticos são } \\
\text { apenas os mais importantes e, de forma } \\
\text { bastante discreta. }\end{array}$ & $\begin{array}{l}\text { 1. Seus elementos ilustram qualquer elemento } \\
\text { abstrata e hipotética. Seus propósitos estão } \\
\text { voltados mais a assuntos limitados, portanto, } \\
\text { para uma clientela típica e reduzida. }\end{array}$ \\
$\begin{array}{l}\text { 2. Geralmente, consiste em um documento } \\
\text { que pode ser usado por longo tempo. }\end{array}$ & $\begin{array}{l}\text { 2. Documento de uso limitado quanto ao } \\
\text { tempo (dados são superados rapidamente) }\end{array}$ \\
$\begin{array}{l}\text { 3. Pouca ênfase nas diferenças quantitativas. } \\
\text { Emprega mais a escala nominal e ordinal, } \\
\text { quase nunca dados derivados dos tipos de } \\
\text { médias, densidades, etc. }\end{array}$ & $\begin{array}{l}\text { 3. Valores mostrados, na escala razão e } \\
\text { intervalar mostrando preocupação com dados } \\
\text { derivados. }\end{array}$ \\
$\begin{array}{l}\text { 4. Não requer conhecimento específico para } \\
\text { sua compreensão. }\end{array}$ & $\begin{array}{l}\text { 4. Requer conhecimento especializado para } \\
\text { sua compreensão, interpretação complexa. }\end{array}$ \\
$\begin{array}{l}\text { 5. Confeccionados por pessoas especialistas } \\
\text { em Cartografia }\end{array}$ & $\begin{array}{l}\text { 5. Confeccionados, na maioria das vezes por } \\
\text { pessoas não especializadas em Cartografia. }\end{array}$ \\
$\begin{array}{l}\text { 6. Cores, geralmente com significado } \\
\text { qualitativo. }\end{array}$ & $\begin{array}{l}\text { Cores geralmente com significado } \\
\text { quantitativo. }\end{array}$ \\
$\begin{array}{l}\text { 7. Uso generalizado de palavras e números } \\
\text { para mostrar os fatos. }\end{array}$ & $\begin{array}{l}\text { 7. Uso extensivo de símbolos gráficos, } \\
\text { especialmente planejados para facilitar a } \\
\text { compreensão de diferenças quantitativas. }\end{array}$ \\
$\begin{array}{l}\text { 8. Quase sempre servem de base para outras } \\
\text { representações. }\end{array}$ & $\begin{array}{l}\text { 8. Raramente servem de base para outras } \\
\text { representações. }\end{array}$ \\
\hline
\end{tabular}

Fonte: Adaptação de MARTINELLI, por ULLER, Adriana S. 2008. 
Como se observa, a Cartografia de Base apresenta informações de forma mais universal, sobre elementos de pouco dinamismo, ou seja, que permanecem durante um período bastante longo, quando não permanentes. Por isso mesmo, se utiliza de uma simbologia mais fácil de ser compreendida por todos. A finalidade de um mapa geral é enfatizar a localização espacial de um fenômeno generalizado. Já no que se refere à Cartografia Temática, como o próprio nome já diz, oportuniza uma infinidade de abordagens, embora de uso mais específico e de duração limitada. A ênfase de um mapa temático está centrada em padrões espaciais, apresentando atributos e variáveis geográficas de aspectos diversos. Logo, um mapa geral também pode ser concebido como uma espécie de mapa temático que representa vários atributos simultaneamente numa mesma espacialidade, dentro de um propósito.

Mapas temáticos podem ser usados em três caminhos básicos: para fornecer informação específica de localizações particulares, para fornecer informações gerais sobre padrões espaciais, e para comparar padrões em dois ou mais mapas (SLOCUM, 2010; 02, tradução nossa).

Muitas vezes a cartografia temática não é trabalhada pelo profissional específico da Cartografia e, isso problematiza em muito, quando não se faz o uso adequado da semiologia gráfica, dificultando a possibilidade de acesso à leitura das informações, pois pode gerar o que chamamos de leitura polissêmica, que mais a frente definiremos. "Uma armadilha para os cartógrafos ingênuos é que muitas vezes colocam a ênfase excessiva em informações específicas" (SLOCUM, 2010; 02, tradução nossa). 
Na questão do turismo, o uso inadequado da produção cartográfica é bastante frequente, e talvez este problema esteja também vinculado a uma necessidade de pensar melhor sobre o mapa voltado para este fim, até porque, só neste campo, temos um vasto leque de possibilidades encontradas para a representação gráfica: os guias de estrada de rodagem, os guias de férias, os guias de eventos, os guias de hotéis e outros serviços de hospedagem, os roteiros de visitações, entre tantos mais.

Conforme afirma Martinelli (1996; 302):

\begin{abstract}
Entendemos que a cartografia do turismo ainda não atingiu sua completa sistematização. Deverá persistir muita conjunção de esforços entre os estudiosos desse setor de pesquisa geográfica com o fim de dinamizar tal forma de comunicação em prol do esclarecimento da sociedade sobre o turismo. A cartografia do território usado pelo turismo pode ser vista como um ramo especializado da cartografia temática, mesmo que ainda não tenha sido sistematizada, diferentemente de alguns ramos da cartografia temática que já possuem certa sistematização, como as representações feitas para geologia, geomorfologia, climatologia e outras disciplinas.
\end{abstract}

$\mathrm{Na}$ sequencia, passaremos a tratar desde assunto com mais detalhes, fazendo um reporte sobre a semiologia gráfica no processo de comunicação do mapa, de modo a contextualizar a pesquisa que desenvolvemos, na análise do mapa turístico local, sua eficácia e a repercussão desse material para os sujeitos usuários. 


\subsection{A Semiologia Gráfica e o Processo de Comunicação}

\section{Cartográfica}

A semiologia gráfica é uma linha de pesquisa cartográfica trabalhada por Jacques Bertin (1967), denominada Semiologie Graphique, sendo um estudo baseado na teoria saussureana ${ }^{5}$ e seguido por grande número de pesquisadores da área em todos os países. Tem como finalidade compreender a natureza da informação para, a partir disso, direcionar a simbolização, ou seja, conferir uma linguagem visual que permita esta apreensão imediata, vista por Bertin como a mais eficiente.

Na semiologia gráfica associamos imagem e comunicação no intuito de compreender como os meios visuais, obedecendo a regras de um sistema gráfico, propiciam melhor tradução visual ou dificultam e até distorcem a leitura e compreensão em um mapa.

Neste sentido é importante compreender que a simbolização é o momento da construção do símbolo (signo), enquanto uma construção própria. Estabelecese a relação entre SIGNIFICANTE (o que se pensa) e SIGNIFICADO (o que se desenha). Os símbolos mais simples de se fazer essa relação são os icônicos, bastante similares aos objetos referentes ao que se considera. Para facilitar a elaboração e leitura de mapas de uso mais técnico - como os topográficos - por parte dos especialistas de formações distintas e de qualquer parte do mundo, foi estabelecido um sistema de símbolos, denominado CONVENÇÕES CARTOGRÁFICAS. (MARTINELLI, 2006).

\footnotetext{
${ }^{5}$ Ferdinand de Saussure (1857-1913) foi um suíço que elaborou a teoria linguística estrutural, baseada em signos, numa tendência estruturalista.
} 
Tal estudo é vinculado à área da Semiótica, que tem por objeto de investigação todo tipo de linguagem possível (podendo ser esta através de símbolos ou signos), dentro do processo de comunicação (SANTAELLA, 2006)

Uma representação cartográfica eficiente deve possibilitar uma visão imediata do que está sendo representado e, não uma leitura que demanda esforço complexo, ou seja, eficiência esta expressa através de certa "naturalidade" de representação. (BERTIN, 1988).

Um exemplo dessa adequação pode ser citado referindo-se à variável visual cor, pois esta, que é uma das variáveis mais utilizadas, se for aplicada de modo aleatório, prejudicará drasticamente a leitura, trazendo dificuldades ao usuário, que será obrigado a consultar a legenda a todo tempo para conseguir tentar entender a informação, sendo que nem sempre obterá este êxito. Assim, se o interesse em usar uma gama de cores for para impressionar com a representação, não irá atender ao propósito primordial que é de facilitar o processo de comunicação entre informação e usuário do mapa.

Com toda certeza compreender toda a complexidade da comunicação cartográfica demanda submeter-se a um desafio teórico e metodológico muito grande e pesquisar um pouco a cerca de linguística, semiologia, semiótica, psicodinâmica das cores, psicologia da forma (Gestalt), etc. Porém, o que queremos enfocar nesse trabalho, é tão somente a mínima reflexão sobre pressupostos básicos e essenciais em um mapa.

Roberto Elísio dos Santos (2003; 9), que trabalha especificamente com estas questões intrínsecas à área de comunicação afirma: 
Muito mais que mera troca de informações, os processos comunicativos abarcam a utilização (e muitas vezes, a criação) de códigos, a interação dos indivíduos, o emprego de tecnologias e a inserção de normas culturais e sociais. Esses processos também estão permeados de ideologias (visões de mundo) e são fundamentais nas relações de poder.

Hoje não só contamos com o emprego da técnica analógica, aplicada em conjunto ao trabalho de campo, mas somos agraciados com o avanço tecnológico, do sensoriamento remoto e do geoprocessamento que facilitam muito o trabalho do geógrafo produtor de mapas, pois estes se utilizam de imagem de satélite, com disponibilizações mais democratizadas, e isso oferece a possibilidade do geógrafo fazer uma pesquisa teórico-prática bastante precisa, com uma análise ampla e ao mesmo tempo sempre atualizada, permitindo ao usuário deste produto final (o mapa), uma leitura mais próxima do real.

Tal façanha ocorre uma vez que os dados podem ser trabalhados por meio do SIG e correlacionados a uma infinidade de questões que propiciam interpretações das ocorrências e, até mesmo, simulações de tratamento dos problemas de representação, antes de chegar ao material final. Porém, é claro, isso demanda conhecimento e experiência profissional do sujeito que opera com toda complexidade desse processo de construção, devendo ser preferencialmente um geógrafo (ou cartógrafo) ou, um profissional com conhecimentos muito correlatos, através de especializações na área.

Dadas estas questões, precisamos entender até que ponto as áreas da Geografia, da Cartografia e do Turismo estão interligadas, para verificar as (inter)dependências teórico-científica e técnico-instrumental em suas ações. 


\subsection{A Geografia e a Cartografia relacionada ao Turismo.}

O campo do turismo vem crescendo muito nos últimos tempos. Tal realidade se manifesta no Brasil intensivamente após a década de 70 , com a criação da Empresa Brasileira de Turismo - EMBRATUR ${ }^{6}$ em 1967, com a política de avanço dos meios e vias de transporte, bem como, com o surgimento da cadeira universitária na respectiva área. A princípio os passos foram lentos, mas no linear dos anos 90, após ditadura militar, houve incentivos grandiosos que favoreceram esta expansão.

Um dos avanços obtidos com a criação da EMBRATUR foi a introdução do Programa Nacional de Municipalização do Turismo (PNMT) em 1994, pois a partir de então os planejamentos poderiam ser focados em nível local. Isso possibilitou que as localidades pudessem resgatar a sua própria história, sem deixar às margens do esquecimento fatos importantes que foram marcados pela participação das minorias, menos expressivas ${ }^{7}$.

Tal situação provocou a demanda de um grande número de profissionais para atuarem neste setor, diante das necessidades de novas atividades correlacionadas: elaboração de inventários, organização de conselhos e criação

\footnotetext{
${ }^{6}$ Atualmente chamado de Instituto Brasileiro de Turismo

${ }^{7}$ Fato este de bastante crítica à EMBRATUR quanto à supervalorização de apenas alguns marcos da história, caracterizando de princípios ufanistas os que direcionam as políticas públicas voltadas ao turismo no Brasil. ULLER, A. S. ULLER, W. \& CARBONAR, M. A (2001) destacam em seu livro a importância de se preservar a memória histórica deste país, pois a mesma sociedade brasileira parece sofrer muitas vezes um processo de amnésia, dificultando sua valorização, pois oculta muitas coisas, impondo outras, por seguir uma ideologia do poder da época. Assinalam que mesmo as minorias, em seu processo de luta de classes se fazem importantes enquanto atores de uma mesma história (conforme estudos de Marx), e que recusar a realidade ou marginalizá-la como mero acessório, é ir contra o passado, é mentir sobre a própria base de formação cultural.
} 
de uma política eficaz para o fundo de turismo. Ciências como Geografia, História e Antropologia foram chamadas a corroborar com a nova área científica que passa a ocupar uma cadeira nas academias, visto que se faz necessário um profundo conhecimento regional em diferentes aspectos para difundir seu potencial de atrativos à visitação.

Porém, em função deste crescimento exaustivo do setor, muito se tem preocupado com a propaganda do serviço, pois se trata de uma atividade econômica bastante lucrativa e que permite certa "comercialização da paisagem" e na política voltada ao setor, pouco ou nada se fala com relação à problemática que iremos abordar: a leitura das paisagens pela produção de mapas voltados ao mercado turístico.

É bastante notório que é possível elencar a cartografia como instrumento de marketing, para a construção de mapas que possibilitarão uma melhor comunicação com o espaço. Lacoste (1988) destaca a função do mapa do processo de promoção da paisagem, do despertar do interesse para o consumo do lugar turístico, chegando a questionar "para que serve a carta?", se para uma agência de turismo ou para se programar as próximas férias, isto percebendo o apelo publicitário que se apresenta massificado em relação de alguns lugares em detrimento de outros.

Pode-se pensar na existência de duas cartografias para esse fim, a de quem irá realizar o planejamento turístico e a do próprio usuário, o turista. Compreender essa diferença é de suma importância para nós geógrafos e para qualquer outro profissional que queira atuar com a produção de mapas. 
O interesse do planejador irá se complementar, muitas vezes, com a realização de pesquisa "in loco" para verificar a demanda, situação da população local, levantamentos físicos dos locais e disposição de serviços de hospedagem dentre outros. Já a cartografia para o turista, que chamaremos de "Cartografia Turística", deve explicar imediatamente, com clareza, de forma mais simplificada, a compreensão das informações através dos mapas, pois será através desta informação, ou seja, do conjunto de significados representados neste mapa turístico, através dos signos (simbologia), orientação e escala, que o visitante irá se guiar para conseguir chegar ao lugar desejado com mais facilidade e entendimento, sem Ihe causar aborrecimentos.

Porém, isso nem sempre vem acontecendo. Atitudes errôneas no processo representativo acabam comprometendo ainda mais o que se espera do mapa de divulgação turística, ou seja, eles podem muitas vezes estar afastando o turista, ou dificultando sua possibilidade de acesso, uma vez que a leitura de um documento informativo, no caso o mapa, seja impossibilitada pela elaboração inadequada.

Alguns autores afirmam que apesar do grande avanço do serviço do turismo no âmbito econômico, no meio científico ainda muitas vezes se banaliza a área do turismo. Diante desse fato acreditamos que talvez isso seja um dos motivos de tratarem dos mapas turísticos também de forma empobrecida, sem se preocupar sequer com o profissional que estará atuando neste âmbito do setor, o de produção do material cartográfico.

Várias são as definições e finalidades do turismo, assim, para cada uma deve haver uma preocupação e um critério específico de abordagem nas 
diferentes ações que o envolvem. Em face desta questão deve ser também pensado a especificidade com relação ao mapa, pois conforme a função destinada ao turismo será o emprego de toda a sua semiologia gráfica e critérios de cientificidade.

$\mathrm{Na}$ sequência passaremos a tratar do assunto "turismo" com sua classificação, de modo a compreender o porquê da distinção de diferentes preocupações por parte do produtor de mapas voltados para este segmento, dando condições adequadas ao uso do mapa requisitado pela demanda a quem foi solicitado.

\section{Definição de Turismo}

Diante das várias concepções de turismo ${ }^{8}$, retiradas do livro Turismo:

8

* É o deslocamento de pessoas isoladas ou em grupos de um lugar para outro, por diferentes motivos e interesses, permitindo o intercâmbio de cultura e união entre os povos;

* É a ocupação do espaço por pessoas que afluem à determinada localidade, onde não possuem residência fixa;

* É o conjunto de relações e fenômenos resultantes do deslocamento e da permanência de pessoas em localidades diferentes daquelas das quais residem ou trabalham, contanto que tais deslocamentos $e$ permanências não sejam motivados por uma atividade lucrativa principal, permanente ou temporária;

* É um conjunto de atividades de natureza heterogênea que impedem a constituição de ciência autônoma e de técnicas específicas independentes. Não dispõe de ordenamento disciplinado e rígido, nem de metodologia própria;

* É a prática de viagens de recreio, visitas a lugares pitorescos, podendo ser também a exploração econômica do lazer;

*É adquirir novos conhecimentos nos locais que possuem as informações que nos despertam interesse. Para que seja considerado turismo é necessário um tempo de permanência de 24 horas e máximo de 90 dias;

* É quando você, sua família ou seus amigos viajam de sua cidade para outro país ou Estado, ou até mesmo outra cidade;

* O vocábulo Turismo vem do latim tournées, cujo significado é o de viagem com traçado definido, indicando o ponto de partida e de chegada, ou seja, indica o trajeto de alguém que viaja e volta ao mesmo lugar que saiu; (SOUZA \& CORRÊA, 2000) 
conceitos, definições e siglas (SOUZA \& CORRÊA, 2000) adotamos uma que consideramos ser a que melhor explica o conceito como um todo:

\begin{abstract}
É um fenômeno caracterizado pelo deslocamento temporário de pessoas de seu local de domicílio (núcleo emissor) para uma determinada localidade (núcleo receptor), com a permanência mínima de 24 horas e a utilização de serviços e equipamentos turísticos. Envolve aspectos tanto econômicos quanto sociais, naturais, culturais, políticos, compondo um conjunto de serviços e equipamentos interdependentes entre si, os quais são oferecidos ao turista por diferentes empresas turísticas. Essas "indústrias" trabalham com atrativos naturais, culturais, sociais, de lazer, de conhecimento, de negócios e outros.
\end{abstract}

Como mencionamos anteriormente, o Turismo possui diversos fatores que influenciarão na sua estruturação e organização, e por sua vez no tipo de mapa a ser produzido, conforme trataremos posteriormente. Também observamos que tal prática social não está vinculada apenas às atividades de lazer, sendo neste novo pensar, um setor que remete à deslocamento de pessoas no território por razões diversas: negócios, aperfeiçoamento profissional, pesquisa, saúde, religiosidade, etc.

Primeiramente cabe aqui apresentar todo o universo que envolve o turismo, para entender onde o profissional da Geografia se encaixa, bem como a importância de sua presença no acompanhamento de tal serviço. Quando pensamos no termo turismo, temos que ter em mente a diferença entre o Turismo Acadêmico, o Serviço Econômico do Turismo, as Políticas Públicas de Planejamento e Gestão do Turismo e enfim o Sujeito Turista. Para cada um destes setores encontramos a necessidade da presença peculiar do Geógrafo, paralelamente ao profissional Turismólogo, e outros profissionais afins. 
No turismo acadêmico, a presença do geógrafo se faz necessária para compreender as identidades, temporalidades, territorialidades e complexidades múltiplas que envolvem o termo "espaço". Para o acadêmico do turismo, além dos mapas de uso geral da sociedade (mapas topográficos e rodoviários) serão inseridos os primeiros mapas temáticos de interesse do turismo, como os locais de formação do turismólogo, as localidades de maior demanda deste profissional, as regiões de maior potencial turístico, as regiões de turismos específicos, etc.

No Serviço Econômico do Turismo, o profissional geógrafo contribui na identificação dos potenciais turísticos que podem gerar recursos, bem como isso deve ser administrado de modo a ser autossustentável, gerando ampliação de empregos e rendas, e, não causando graves problemas que podem trazer mais déficit que lucros.

Nas Políticas de Planejamento e Gestão, envolvem não somente os interesses econômicos, mas também as preocupações ambientais e sociais, referentes à proteção do meio ambiente bem como da própria identidade cultural de cada lugar, de modo que o turismo seja um serviço contribuidor para a comunidade, que não mate sua qualidade de vida e seus referenciais para sua população gerando tantos impactos negativos, sejam no aspecto ambiental, social ou cultural. "Uma indústria do turismo mal planejada gera problemas irreversíveis, a população perde sua identidade, se adapta aos costumes estrangeiros para agradar aos turistas". (FENNELL, 2002; 103)

Nesta ocasião, e ainda no caso da exploração econômica, o mapa é primordial, para se verificar as áreas do entorno, os impactos que podem ser gerados ao ambiente ou à comunidade local, os raios de influência infraestrutural, 
enfim, uma coleção de mapas que permita aos seus profissionais um estudo amplo e aprofundado sobre determinado serviço, bem como, garantindo a legitimidade de tal instrumento de informação. "Num sentido mais simplista, política de turismo é a identificação de uma série de metas e objetivos que ajudam uma agência - geralmente governamental - no processo de planejamento da indústria do turismo" (FENNELL, 2002; 132).

É extremamente necessário que todo e qualquer documento de informação sobre o espaço geográfico a ser visitado seja fiel em suas características e permitam a receptividade da informação por parte do turista. Portanto, com relação ao próprio turista, o geógrafo pode atuar na produção dos materiais de divulgação locacional, uma vez que é de vital importância a utilização de códigos de linguagem (semiologia) acessíveis e adequados ao leitor, usuário dos mapas e, que estes também apresentem informações corretas, que permitam aos visitantes chegar aos respectivos lugares e, portanto, sem distorções agravantes com relação à orientação, escala e legenda que são os componentes fundamentais do material gráfico.

Nesta óptica entendemos que não basta produzir mapas voltados ao setor se estes não forem devidamente apropriados aos respectivos "usuários" do mesmo. Há de se pensar que além desses profissionais, geógrafos e turismólogos, bem como agentes do turismo, ainda atuam de frente a este setor, o serviço de Marketing, também uma área própria do turismo, que muitas vezes ocupam o lugar de geógrafos, na documentação de materiais informativos de cunho cartográficos. "Com a regulamentação tem surgido também nos últimos 
anos, uma preocupação crescente com a qualificação e a certificação e o profissionalismo na indústria do turismo". (FENNELL, 2002; 149).

A atuação dos profissionais do Marketing enquanto produtores de mapas tem sido um foco bastante problemático para o campo científico, principalmente para nós geógrafos que atuamos frente às críticas das práticas sociais na ocupação e organização do espaço. Os "marqueteiros"" têm como principal objetivo a propaganda, ou seja, a venda do produto, com isso deixa de lado, os importantes objetivos da comunicação, neste caso a linguagem simbólica efetiva, com os elementos de respectivos "significantes-signos-significados", atribuindo mais vínculo artístico que geográfico aos mapas de uso do turismo. Pior que isso, eles vendem a paisagem fazendo grande apelo à forma ilusória, sem preocupação com o impacto disso para as questões sociais e nem mesmo para com um compromisso ético para com os usuários consumidores daquele espaço enquanto turistas.

Fennell $(2002 ; 170)$ explica:

\begin{abstract}
O marketing dos produtos de turismo é fortemente baseado numa firme compreensão do fato de que o mercado abrangente do turismo é dividido em segmentos selecionados de mercado. As agências de viagem não têm as condições de atender ao mercado de viagens em geral, nem a inclinação para isso, dada a magnitude do movimento doméstico convencional. (...) O marketing direcionado pode ocorrer de quatro maneiras principais: (1) geograficamente, com base no espaço geográfico; (2) demograficamente, baseado na idade, no gênero, na religião, na raça, etc; (3) psicograficamente, baseado nos estilos de vida, atitudes, valores e personalidades dos indivíduos; e (4) nos benefícios, que incluem uma análise dos benefícios desejados pelos turistas, e dos custos que eles procuram evitar.
\end{abstract}

\footnotetext{
${ }^{9}$ Assim chamados os profissionais ligados à atuação de marketing.
} 
Diante disso, passaremos a refletir sobre esta problemática que envolve o mapa enquanto instrumento de comunicação, ou seja, o mapa enquanto representação da paisagem através de simbologias gráficas.

\subsubsection{A Cartografia aplicada ao Turismo}

A partir dos anos 70, com a introdução da informática na Cartografia, foi possível observar certa revolução do dinamismo da ciência em sua forma de conceber, criar, estruturar, armazenar, manipular, analisar e distribuir mapas (RAMOS, 2005;15).

Tal informatização permitiu algo ainda não experimentado anteriormente:

Os sistemas de informação geográfica (SIGs), a multimídia e a internet tornaram a cartografia novamente interativa na medida em que, quando colocados para trabalhar a favor da cartografia, permitem que o usuário "converse" agora não mais com o cartógrafo, mas com o mapa. (RAMOS, 2005; 16).

\section{Objetivos da Imagem-Comunicação no Marketing do Turismo}

Constantemente pessoas recebem em suas mãos um folder, ou outra forma de propaganda turística impressa com a presença de fotos e demais documentos cartográficos, principalmente mapas. Muitas vezes os indivíduos não 
se preocupam em olhar com atenção o material elaborado, a menos que necessitem visitar determinadas localidades que ali são apresentadas. Na maioria destes materiais de propaganda são encontrados mapas bastante diferentes daqueles utilizados no campo científico. Estes apresentam uma linguagem polissêmica, diferente da habitual linguagem cartográfica que é monossêmica, e ainda utilizados recurso iconográficos diversos, distantes dos referenciados pela semiologia gráfica acadêmica.

A seguir, é ilustrado um exemplo de mapa deste gênero, bastante frequente nos folders turísticos.

Figura 3: Exemplo de folder com mapa turístico - Curitiba

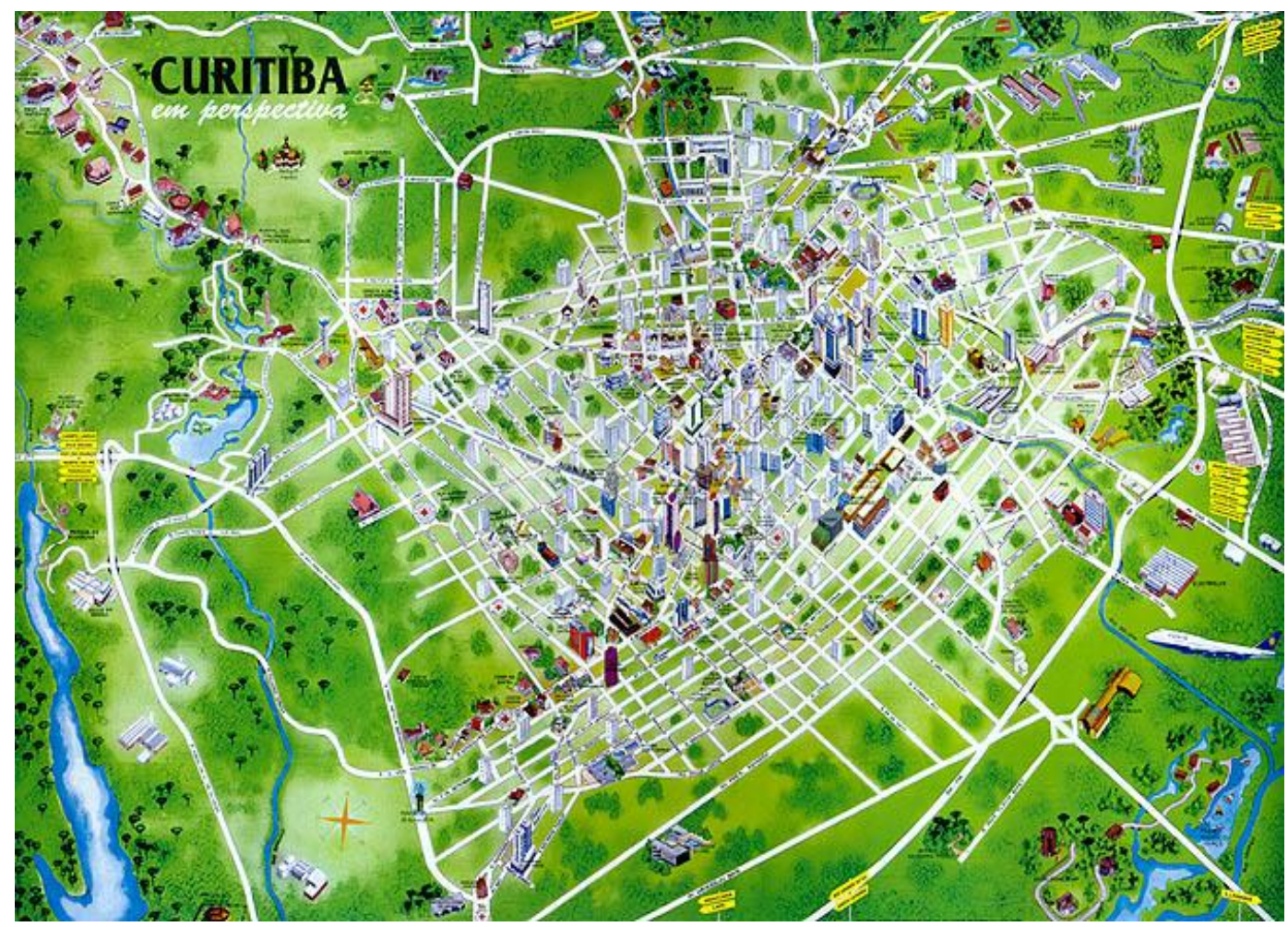

Fonte: Empresa de Propaganda Hoteleira. (s/f). 
Neste exemplar percebemos que elementos cartográficos se confundem. Utilizam referências pontuais, lineares e zonais, em conjunto com desenhos pictóricos. Também não há qualquer especificação detalhada dos lugares, nem classificação do tipo de recurso turístico ofertado. Apresenta-se somente uma imagem quase que abstrata da área curitibana, demonstrando a diversidade de atrativos, isso favorece ao que se denomina polissemia (vários significados).

Este seria o primeiro ponto chave a se pensar ao elaborar um mapa turístico: Qual a finalidade do mesmo? Que tipo de recurso se pretende ofertar? Qual a melhor forma de representação dessa potencialidade? Isso dará uma informação correta e oportuna ao usuário? Tais elementos de reflexão estão expostos no Fluxograma que segue.

Figura 4: Fluxograma - A distribuição dos recursos turísticos

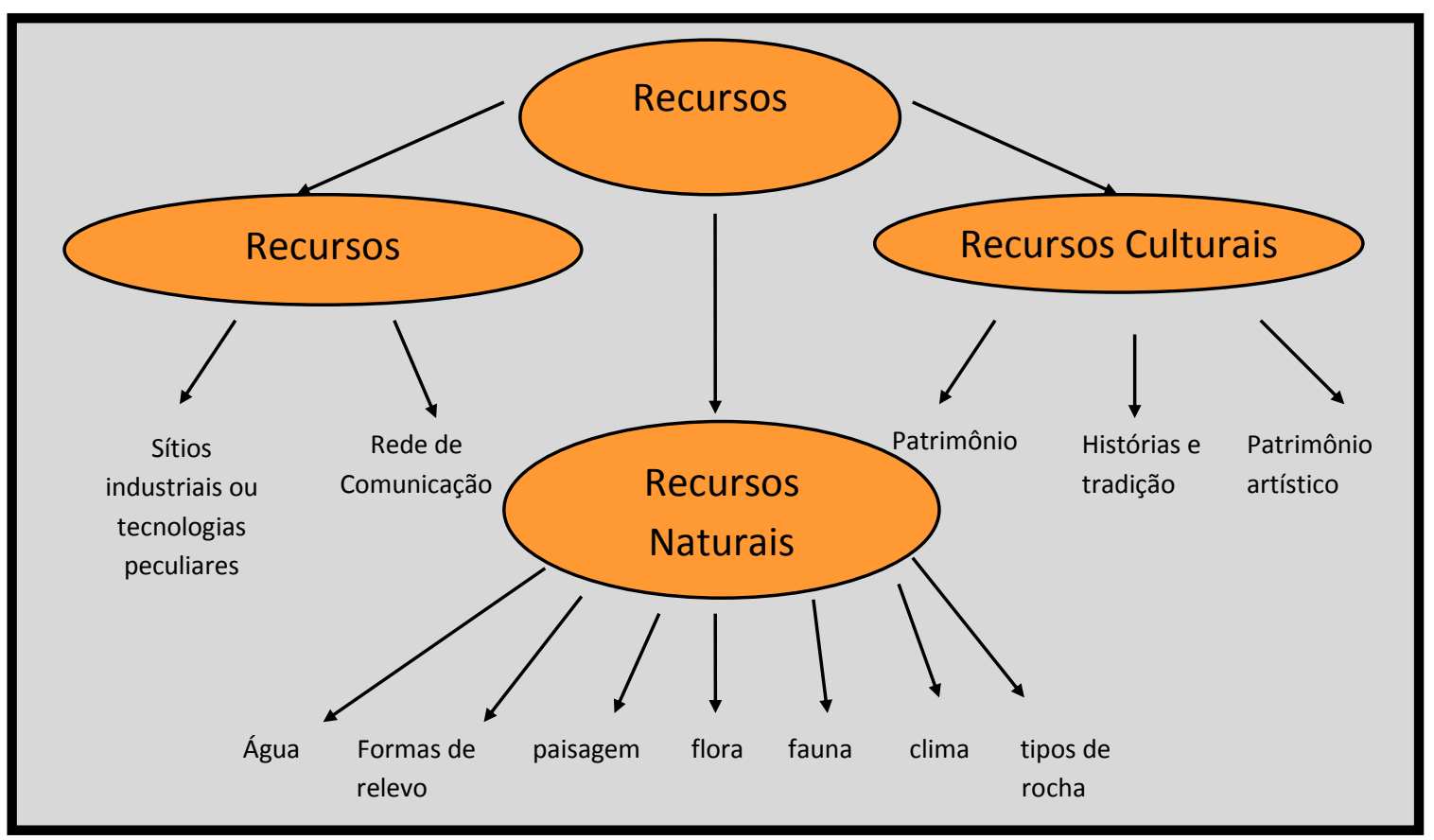

Fonte: QUEIROZ, 2006 (adaptado de Guigo, 1995). 
Daí a importância da ligação deste produto, o mapa, destinado ao turismo, com a Geografia, já que esta ciência é que tem as condições de executar uma revisão crítica sobre a abordagem espacial e fazer as melhores escolhas simbólicas de representação cartográfica. Dito isto, passamos a compreender a lacuna que fica aparente em mapas elaborados por profissionais que desconhecem a especificidades da cartografia geográfica, que nada tem a ver com objeto de artes gráficas, mesmo que possa se utilizar dela.

Seja no campo da comunicação, ou ainda no operacional, observando o conteúdo do mapa, no contexto em que é criado, percebe-se que este cumpre, acima de tudo, uma função social atrelada ao seio de uma sociedade capitalista. Assim, em nenhum momento pode estar isento da condição de documento inerente a uma indústria do lazer e a serviço de alguma ideologia.

Barbosa $(2003 ; 429)$ apresenta resumidamente suas ideias da seguinte forma:

A publicidade exerce um papel de persuasão por meio de imagens com a finalidade de atrair o consumidor. Na sociedade atual dá-se muita importância aos símbolos que conferem status; por isso, o turismo preenche muito bem essa necessidade de consumo das pessoas. ${ }^{10}$

${ }^{10}$ Barbosa (2003; 430 e 431) explica:

A partir do momento em que se leva em consideração o fato de que toda uma parte do comportamento econômico não é racional e consciente, mas se desenvolve sob o plano do automatismo mental, surge a possibilidade ao condicionamento mental em que o consumidor fica mais vulnerável para perceber a situação em que se encontra. Essa forma de propaganda gera uma obsessão inconsciente, levada pela repetição de slogans, de imagens provocantes. A intensidade do estímulo publicitário deve reforçar este condicionamento pela força do apelo visual, por meio de cores fortes, estimulantes.

(...) Toda informação é inconscientemente carregada de valores sociais e de imagens afetivas: o fato de não controlá-las deixaria o cliente receptor passível de livre interpretação. O consumo oferece uma compensação psicológica das necessidades insatisfeitas, sonho e projeção simbólica num universo paralelo, permissível aos desejos e pulsões reprimidas. 
Esta ideologia perpassa diferentes caminhos até se chegar ao produto final e, são estes que vão dar o arcabouço do mapa turístico.

Para entender todos os participantes deste processo, (empresários, operadoras de turismo, estudantes do setor, sujeito turista, órgãos de planejamento e orientação do serviço, imprensa e demais grupos pertinentes) apresenta o seguinte fluxograma, onde é possível observar a formação de todo o sistema:

Figura 5: Fluxograma - Modelo de comunicação na área do Turismo

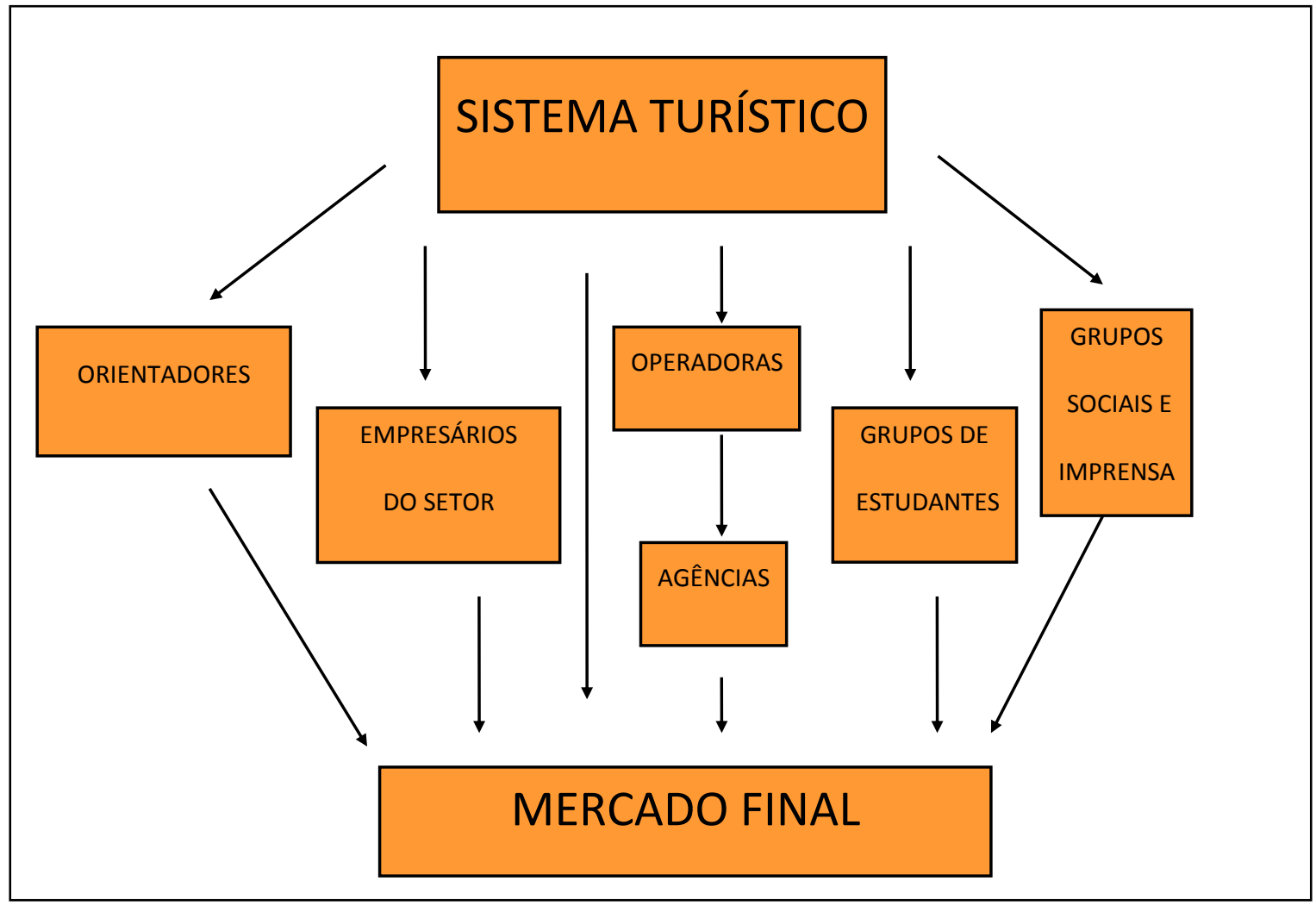

Fonte: PETROCCHI, 2001 apud OLIVEIRA, 2002.

9 [...] Barbosa (2003; 433) ressalta: "O erotismo também pode ser enquadrado nas formas de seduzir o consumidor... Observa-se a exploração do "belo", mulheres exibindo um corpo escultural provocativo, sedutor, nas imagens das propagandas turísticas". 
A participação de todas estas parcerias no processo de idealização e produção do mapa compromete muito do resultado, colocando as ideologias em prioridade com relação ao ideal técnico-científico. Para compreender melhor, segue-se um tratamento a respeito, onde serão enfocadas as preocupações problemas referente aos mapas de uso turístico, tendo como olhar, a visão do Geógrafo, que se preocupa, em muito, com a formação das consciências e visões de mundo, a partir do entendimento e "desprendimento" das ideologias presentes.

\subsubsection{A produção de mapas voltados ao Turismo}

Nesta parte do trabalho, serão abordados os exemplos de mapas turísticos e os problemas em específico, que comumente se depara.

\section{\# Preocupações e problemas}

Os produtos cartográficos de turismo não podem se eximir da responsabilidade que possuem por participarem no campo das comunicações, nas particularidades da Cartografia. Por assim dizer, suscitam dois tipos de problemas, o do conteúdo e o da linguagem adaptada ao caso específico.

Koeman (1995; 3), acerca da comunicação, narra a difícil tarefa de experimentar as funções específicas dos mapas por grupos específicos de usuários. Segundo o autor, o sentido mais amplo do mapa é a comunicação, ou ainda se reportando à (OLIVEIRA, 2002; 13): como dizer? O que dizer? Para quem dizer? . Tais considerações são fundamentais antes mesmo de se planejar o mapa, pois elas direcionam os caminhos, métodos e instrumentos a se utilizar 
para tornar o instrumento representativo, o mapa, um material eficiente que possa atingir os seus reais objetivos de comunicar e (in)formar.

A seguir, apresentamos através de dois fluxogramas distintos, a complexidade do processo de codificação e decodificação no mapa, elaborados por dois geógrafos que atuam na Cartografia, em diferentes abordagens, porém com uma coerência de visão sobre o caminho percorrido para alcançar a cognição almejada, ou seja, o apreender a informação comunicada no mapa.

Figura 6: Fluxograma 3- Sistema de informação-comunicação da Cartografia

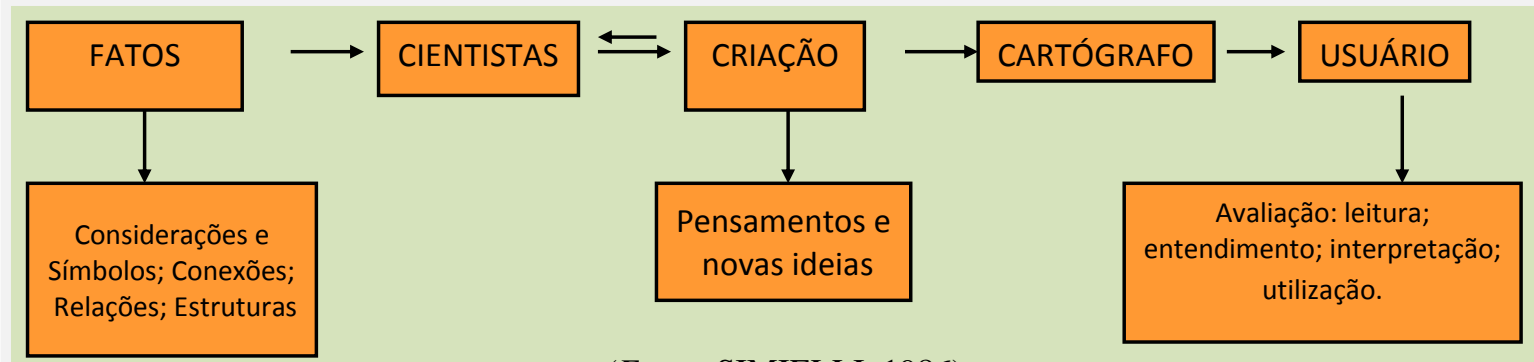

(Fonte: SIMIELLI, 1986)

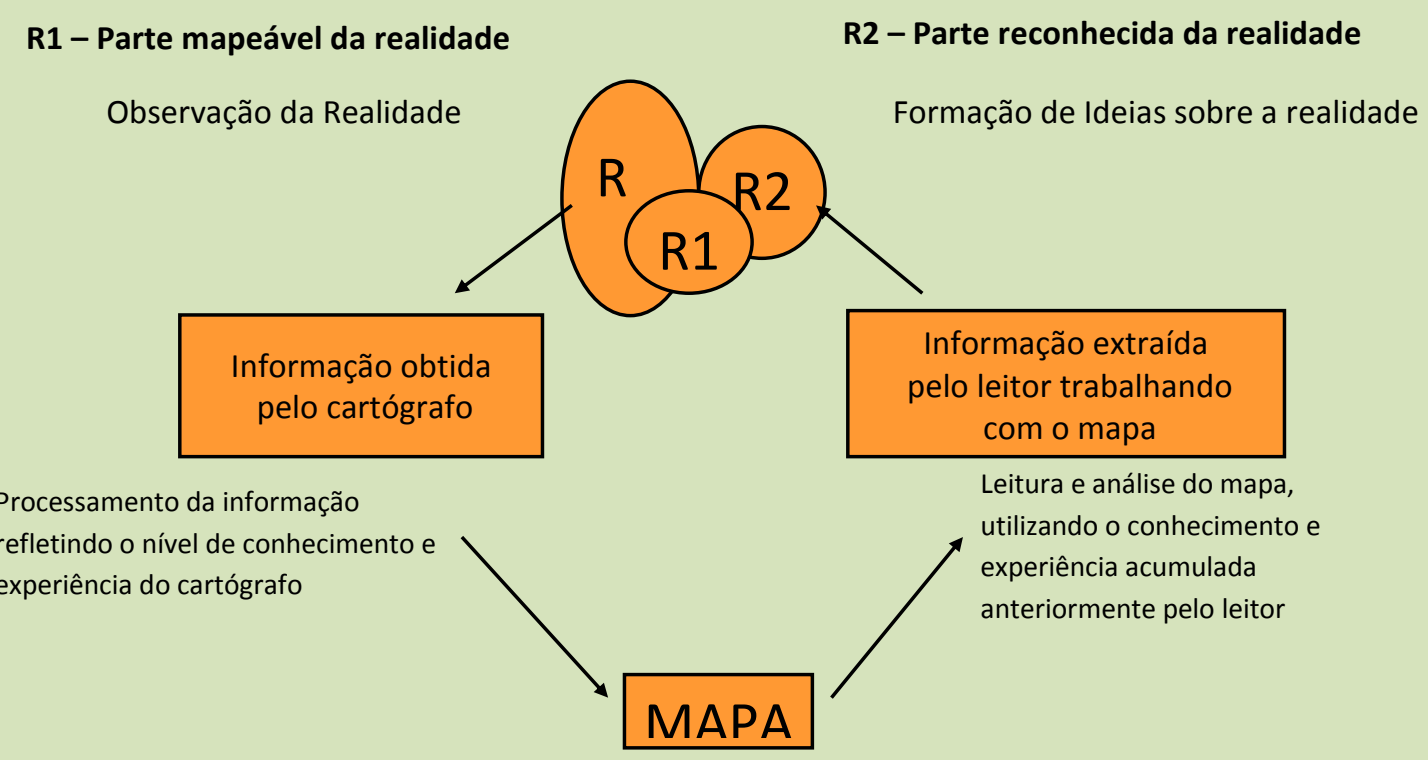

(Fonte: MARTINELLI, 1991; 37) 
Tais elementos dos fluxogramas (3), apresentado pelas concepções de Simielli(1986) e Martinelli (1991), demonstram o processo correto de reflexão entre a idealização e construção de um mapa, para se alcançar uma melhor exatidão e aproveitamento. Ambos destacam que há certa distância entre o Cartógrafo e o Usuário do Mapa conforme também afirma Kolacny (1995).

Isso se torna em um grande problema quando não levado em consideração no processo de construção do mapa, pois pode acarretar em sobrecarga de tecnicismo restrito à profissionais, ou ao contrário, banalizar tanto a informação, a ponto de nem se alcançar o objetivo esperado. Logo deve haver uma mediação equilibrada entre estes dois sujeitos, de modo a conduzir a informação desejada, por meio desse instrumento comunicativo que é o mapa.

$\mathrm{Na}$ relação entre estes dois sujeitos, construtor e usuário do mapa ainda entra em questão a semiologia gráfica (BERTIN, 1977), que é o estudo de toda uma simbologia atrelada aos seus respectivos propósitos, para se atingir os objetivos da informação.

\subsubsection{As possibilidades de representação e leitura coerente}

Nossas preocupações no âmbito da Cartografia não se referem a um corporativismo profissional, uma luta por campo de trabalho, pois cremos que trabalho há para todos, até mesmos para aqueles especializados em outras áreas que tem por paixão os mapas e por isso resolveu trabalhar nessa área. 
O que pretendemos, portanto, enfocar com grande crítica, é a necessidade de uma maior responsabilidade para com a qualidade e eficácia dos mapas, em respeito ao usuário, leitor dos mapas, bem como para não reduzir o conhecimento teórico e científico dos mapas frente os seus pressupostos básicos consolidados na longa história da Cartografia, estando agora numa nova roupagem da modernidade, atrelados às novas tecnologias e à complexidade espacial.

O intuito é fornecer, portanto maiores subsídios ao leitor e usuário de mapas de modo a ser capaz de responder questões sobre quais informações reais estão sendo representadas?

Ainda neste mesmo sentido, ter a consciência de se perguntar: Como o recurso tecnológico transforma as imagens da paisagem numa leitura pictórica para o mapa? É bastante possível que os leitores sejam capazes de diferenciar o potencial de condições possibilitadas por um mapa impresso no papel e um mapa interativo na internet, porém, até que ponto eles são capazes de refletir no momento de uso dos mapas sobre as questões que ora elencamos?

Para reconhecer a existência destas questões é preciso ter em mente os passos que se usa para construir um mapa e, o produtor de mapas, seja cartógrafo ou um profissional que atua com a produção de um documento gráfico, deve ser o primeiro a ter isso bem claro.

Na sequência apresentamos os passos para um mapeamento temático como contribuição de Slocum (2009): 
Figura 7: Passos para o Mapeamento Temático

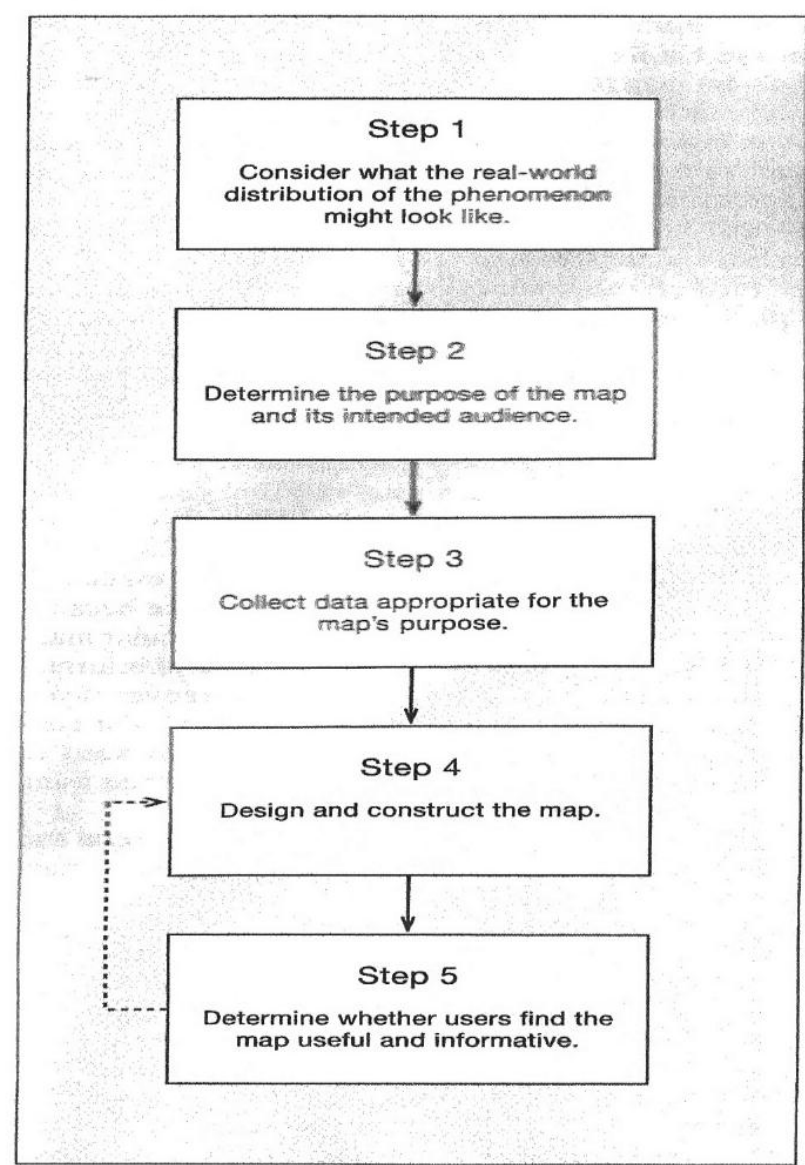

FIGURE 1.3 Basic steps for communicating map information to others.

Fonte: Slocum et al $(2009 ; 05)^{11}$

Slocum afirma que "Apesar de algumas críticas sobre a adequação de tais medidas, estas são úteis para evitar os erros de designer que podem resultar da utilização dos dados mais facilmente disponíveis e software" (2009; 1. tradução nossa).

${ }^{11}$ Figura 1.3. Passos básicos para comunicar as informações do mapa para os outro: Etapa 1. Considerar que a distribuição do mundo real do fenômeno pôde olhar como. Etapa 2. Determinar a finalidade do mapa e seu público-alvo. Etapa 3. Coletar dados adequados para a finalidade do mapa. Etapa 4. Projetar e construir o mapa. Etapa 5. Determinar se os usuários a encontrar o mapa útil e informativo. 
Diante de tais medidas, parece bastante fácil atuar com o grande número de recursos disponíveis através do avanço da tecnologia, como o sensoriamento remoto e o geoprocessamento, porém Slocum, aponta no capítulo 4 de seu livro, algumas das consequências dessa mudança tecnológica, no campo da cartografia:

(1) a capacidade de praticamente qualquer pessoa criar mapas utilizando computadores pessoais; (2) novos métodos de mapeamento, tais como mapas animados; (3) a capacidade de explorar dados geográficos em um ambiente gráfico interativo; (4) a capacidade de link mapas, textos, imagens, vídeo e som em apresentações multimídia; (5) a capacidade de criar representações realistas do ambiente (ambiente virtual ou realidade virtual) e relacionadas com a noção de realidade aumentada (ou seja, aumentar a nossa visão do mundo real através de informação baseada em computador); (6) a capacidade de acessar os mapas e informações relacionadas através da web (SLOCUM: 2009; 1 )

Assim, percebemos que o avanço da tecnologia na ciência geográfica, ou as chamadas "geotecnologias" devem comportar em seu objetivo maior um compromisso com a dimensão social e política, dentro de uma perspectiva crítica e ética que permita utilizar do instrumento de representação espacial, o mapa, para verdadeiramente informar o cidadão que anseia por este recurso. (Matias, 2001)

O termo visualização científica tem sido estudado fora do mundo da Geografia, podendo ser até de interesse de estudos médicos, como estrutura molecular, por exemplo. Emprestando esta ideia, geógrafos criaram a ideia de geovisualização ou visualização geográfica. Para o autor, a geovisualização tem sido uma atividade praticamente particular, onde incógnitas são possíveis de ser 
reveladas num ambiente altamente interativo, enquanto ao contrário, os mapas impressos, voltados ao público, não apresentam nenhuma interatividade. (SLOCUM 2009; 1-2)

Enquanto o avanço tecnológico tem tido um maior impacto na cartografia, a disciplina também tem experimentado mudanças em suas perspectivas filosóficas.

Os estudiosos citados, Kolacny (1995) e Bertin (1977), são algumas das preciosas contribuições no campo da ciência cartográfica para se obter um maior êxito na construção e leitura de mapas. Tais autores abordam muito a relação cognitiva entre o construtor do mapa (cartógrafo/geógrafo), o instrumento de comunicação (o mapa) e o leitor do mapa (usuário/turista).

Estas preocupações sobre as questões do entendimento do mapa e seu ensino vêm sendo estudadas em pesquisas desenvolvidas no Brasil a partir da década de 70, e servem para auxiliar nesta análise sobre os mapas turísticos em sua complexidade.

\section{Variáveis Visuais ou Variáveis da Retina e Tipos de Implantações}

O domínio da Cartografia, ou seja, das representações gráficas, integra um sistema de sinais que tem por finalidade promover a percepção quase que imediata da realidade através da imagem representada, chama-se isso de linguagem monossêmica, que possibilita uma única interpretação, ao contrário da 
linguagem polissêmica que integra uma variedade de artifícios muitas vezes abstratos, dificultando a leitura e favorecendo múltiplas interpretações de acordo com o imaginário de cada leitor. Os mapas turísticos tendem a esbarrar nesta segunda situação.

Conforme estudos de Bertin (1977), para se obter uma linguagem monossêmica, que é a própria da Cartografia, na produção de um mapa, se faz necessário um conhecimento da semiologia gráfica que integra entre outras bagagens, o saber sobre as variáveis visuais ou variáveis da retina, tipos de implantações, a problematização da poluição de informações, também conhecida como sobreposição de dados excessivos.

As Variáveis Visuais mais utilizadas são seis: tamanho, valor, granulação, cor, orientação e forma.

Os tipos de implantação variam entre pontual, linear e zonal, podendo muitas vezes estar presente apenas um deles ou mais, para se transmitir a informação.

A seguir, apresentamos um quadro que geralmente aparece nos livros, ilustrando estas seis variáveis nos três tipos de implantação. Aqui, utilizamos uma fonte em Monmonier, de modo a demonstrar a interação entre trabalhos entre os vários estudiosos aqui citados. 
Figura 8. Variáveis Visuais e Tipos de Implantação

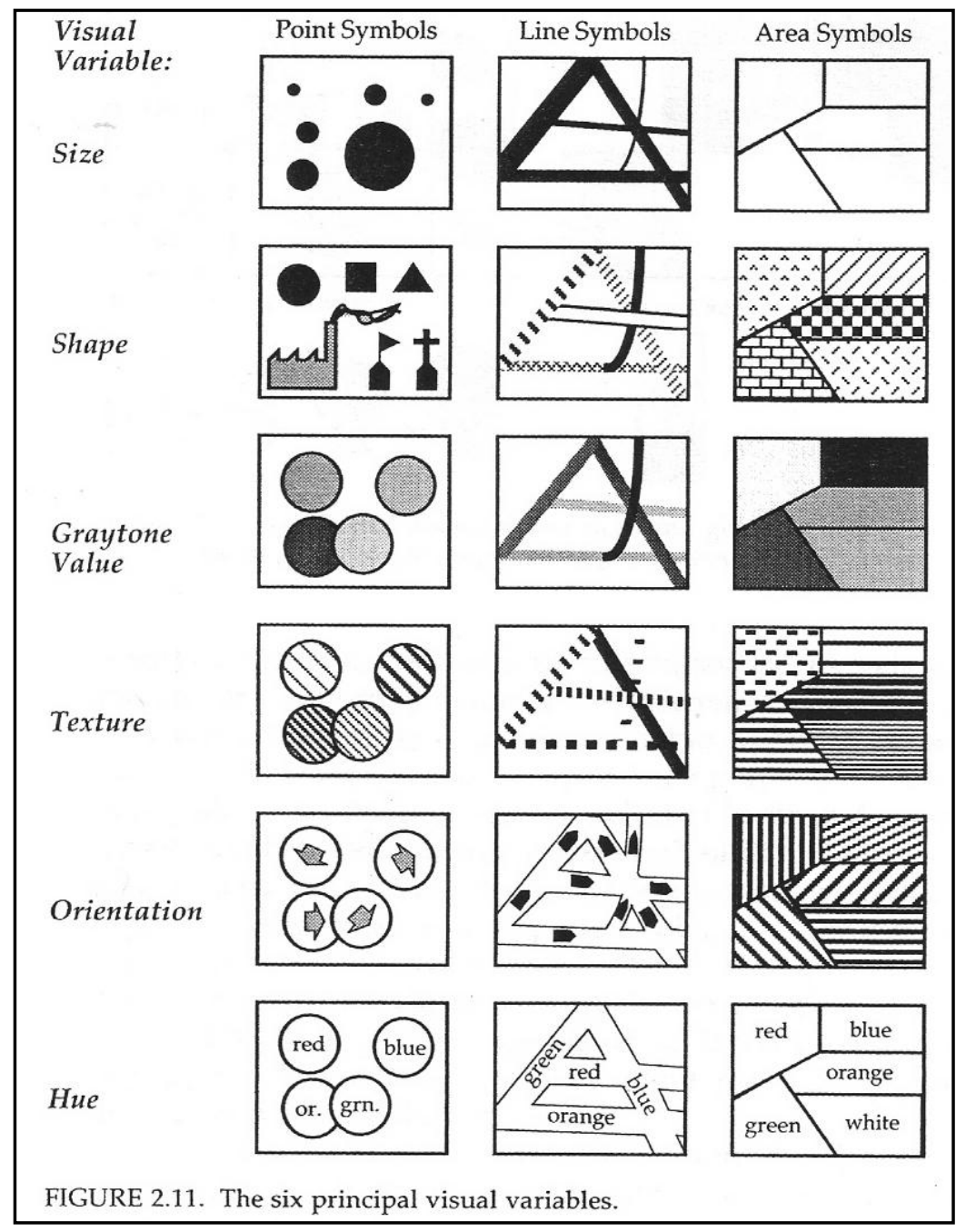

Fonte: Monmonier, Mark (1991; 20)

A poluição visual ou sobreposição de informações é a solução exaustiva, aquela que superpõe vários atributos sobre um mesmo mapa. A grande maioria dos mapas temáticos é resolvida dessa forma. Não fornece resposta visual instantânea às questões de conjunto, geralmente as mais solicitadas pelos usuários: "Como é a distribuição espacial de tal atributo?", "Tal atributo, onde está?" Responde apenas às questões de nível elementar: "Em tal lugar, o que há?" (MARTINELLI - 1991; 40). 
Diante do que se sabe destas necessidades do mapa, se defronta com o problema da cartografia do turismo, que se apresenta num relativo vazio nas produções acadêmicas, quando comparado a outros ramos da cartografia. Entendemos que a elaboração de representações gráficas para a indústria das viagens, é um dos maiores negócios da área da cartografia hoje e, vem se constituindo num componente imprescindível do processo de desenvolvimento do turismo.

A produção em massa de mapas de turismo por empresas especializadas vem mostrando a substancial ausência dos profissionais da comunicação cartográfica (cartógrafos e geógrafos) permitindo assim que essa mais recente popularização dos mapas se faça sem qualquer respeito às regras básicas, ora da comunicação em si, ora do que representa a produção de identidades físicas do espaço e sua representação. A seguir, é possível visualizar, através de exemplos de mapas turísticos, a variação de produtos cartográficos e que as finalidades e localidades interagem no processo de decisão das representações bem como em seus resultados.

\subsubsection{Tipos de Mapas Turísticos presentes no mercado}

Diversos são os tipos de mapas que encontramos no mercado turístico, ou seja, destinados ao visitante turista, que busca através desse instrumento informações de localização e peculiaridades importantes que vão lhe servir de referência de serviços de interesse e mesmo no despertar de vontade de 
visitações. Cada tipo de mapa utiliza de diferentes formas de representações, algumas mais ligadas à cartografia científica, reconhecida aqui por nós como "verdade", visto que atende às necessidades buscadas neste material cartográfico, outros, sem qualquer aproximação com a ciência, talvez mais próximo da arte, hoje com o viés gráfico computacional, que embora conduza o visitante a uma fantasia em seu imaginário, vendendo lugares dos sonhos, não favorece a credibilidade dos usuários, causando até mesmo problemas em seus deslocamentos no espaço visitado e, criando uma antipatia pelo lugar e pelo mapa por não serem compatíveis.

$\mathrm{Na}$ sequência distribuímos esta variedade de possibilidades de mapas turísticos, numa classificação de finalidades e formas de representação cartográfica empregada.

\section{Quanto ao tipo de implantação}

Quando a informação é representada pontualmente é porque está relacionada a um par de coordenadas que dão a localização do fenômeno representado. No caso da informação ser linear, refere-se não a um único ponto, mas uma sequência deles, pois estão relacionadas a mais de um par de coordenadas. Já com relação à informação representada zonalmente, diz respeito às regiões mais abrangentes e, que embora definidas, se estendem por um percurso maior, numa série de coordenadas fechando polígonos.

O modo de implantação também configura aspectos quantitativos (em valores proporcionais) ou qualitativos (seletivos). Isso se representa 
associadamente às variáveis visuais de tamanho, valor, granulação, forma, orientação e cor. Conforme o interesse, se aplica a variável ao ponto, à linha ou à área.

Vejamos a seguir como isso tem sido expresso nos mapas turísticos:

MAPA 2: Mapa turístico utilizando implantação pontual

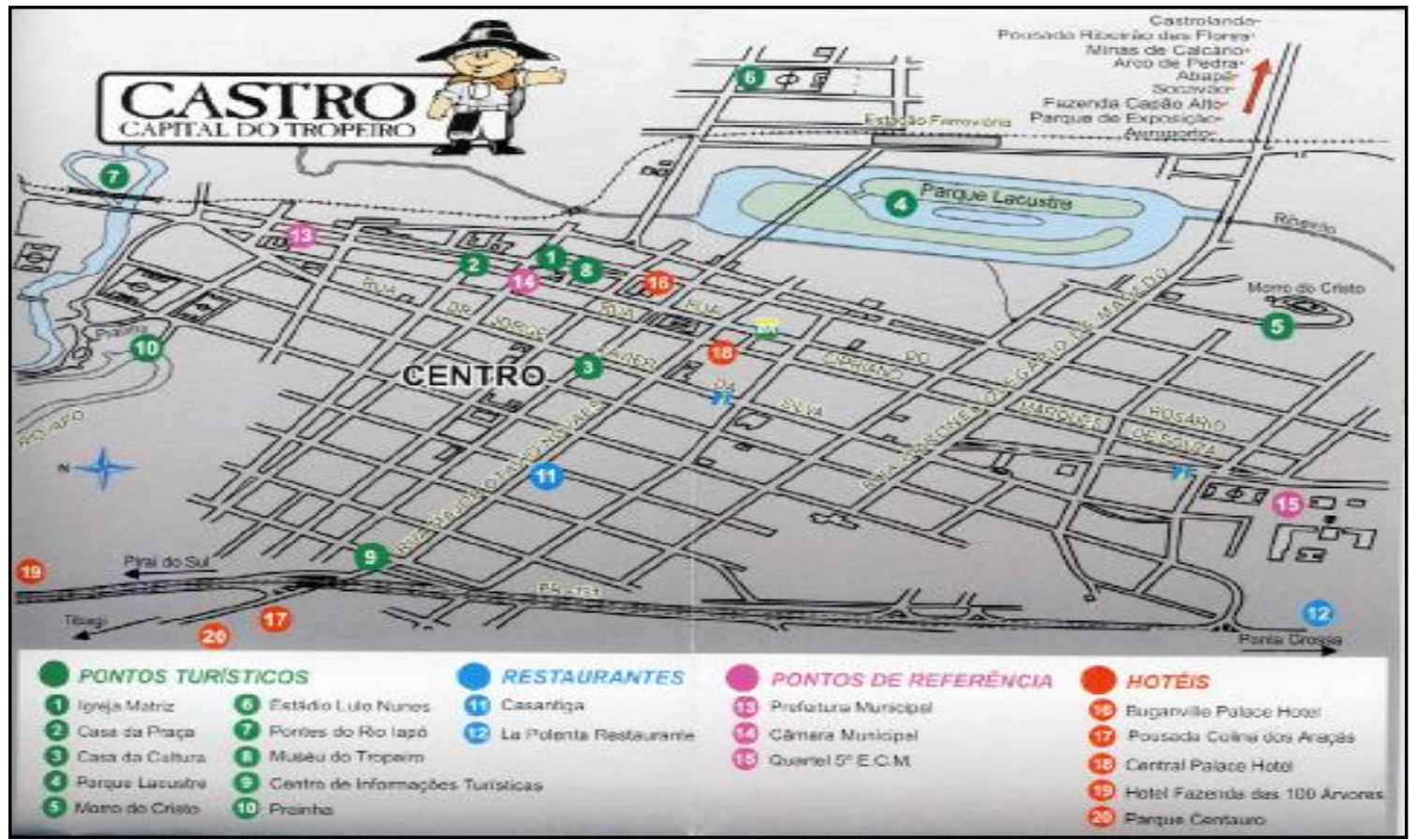

Fonte: CASTROTUR / Conselho Municipal de Turismo de Castro - PR

No mapa 2, foi utilizada a implantação pontual para se localizar os lugares referenciados e ainda a variável seletiva Cor, para diferenciar as finalidades apresentadas: pontos turísticos, restaurantes, pontos de referência e hotéis. Cada ponto foi enumerado, facilitando a identificação particular de cada um. Este mapa apresenta uma situação cartográfica bastante favorável ao leitor, uma vez que, também retrata elementos importantes como a orientação geográfica da área. 
MAPA 3: Mapa turístico com exploração da implantação pontual e linear

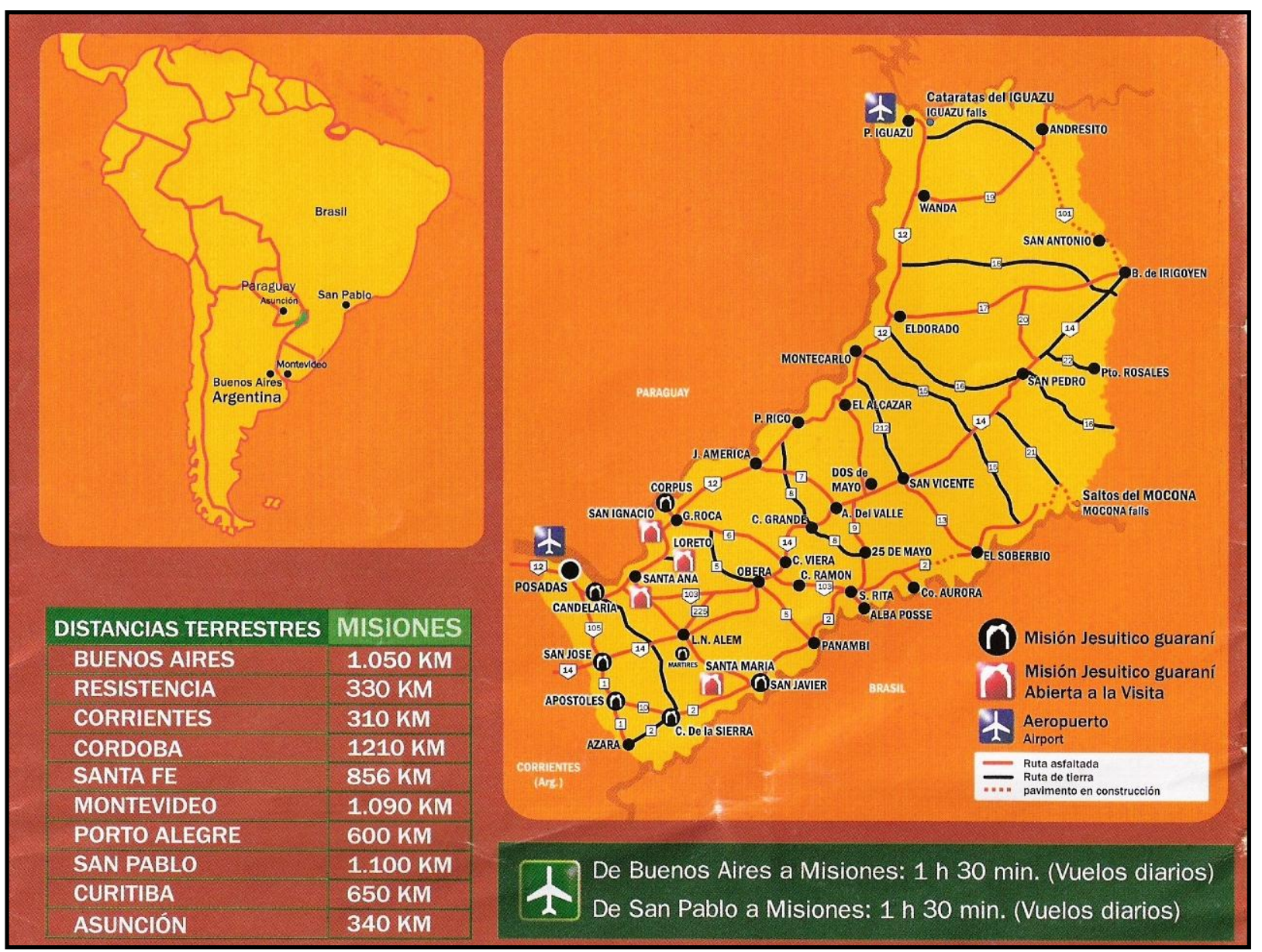

Fonte:República da Argentina / Gobierno de la Província de Misiones.

O mapa 3, retrata, através da implantação pontual e linear, critérios seletivos sobre os tipos de vias de acesso (cor) e locais de visitação e referência (cor e forma). Traz, ainda, um encarte da localização continental da região e suas distâncias terrestres com outros referenciais.

Os encartes são elementos complementares que aparecem num mapa com o intuito de melhor explicar algo, localizar ou mesmo ilustrar. No meio digital são chamados de "hipertextos", porém é desconhecida tal atribuição conceitual ao meio impresso. A seguir, é apresentado outro mapa turístico, com diferente 
função dos encartes, desta vez fotográfica, num mapa de implantação pontual e linear simultaneamente.

MAPA 4: Mapa turístico com exploração pontual, linear e encartes de imagens.

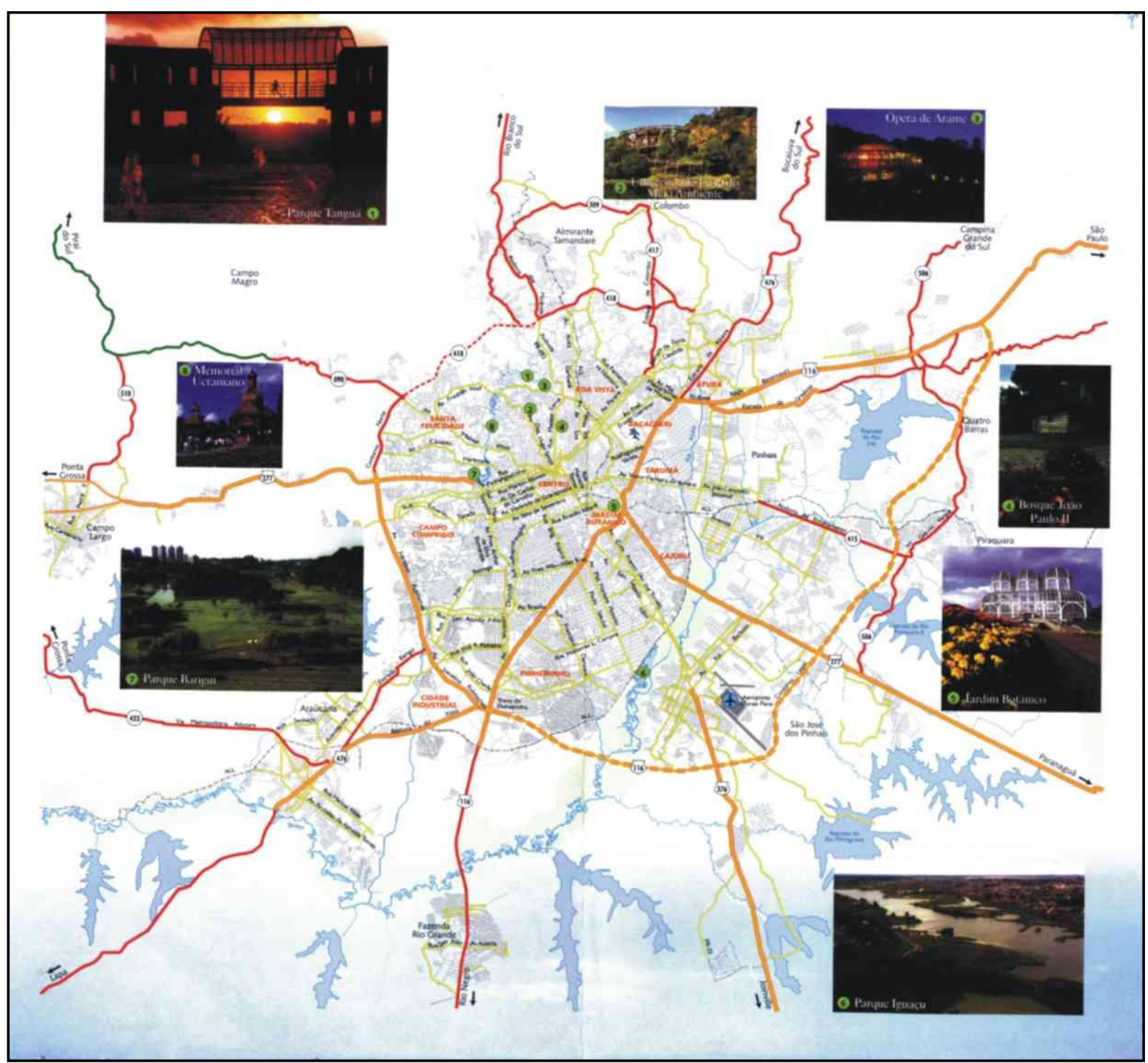

Fonte: Estado do Paraná / SETR - Secretaria de Estado dos Transportes

É possível perceber que neste mapa anterior privilegiaram as imagens turísticas em detrimento das localizações, pois, a escala utilizada dificulta a leitura. Já no mapa seguinte, utilizaram de implantação zonal com recursos pictóricos artísticos, com encarte fotográfico das localidades, mostrando o aspecto 
real. Este tipo de representação tem sido muito comum em mapas turísticos, porém, contempla só o aspecto ilustrativo do marketing, mas dificulta informações concretas como a localização e distâncias, por exemplo. Embora chamando a atenção dos turistas para o aspecto visual, afasta-os pela desinformação, fazendo com que os mesmos tenham que se informar através de outros caminhos, como o questionamento local com frequentes paradas, que nem sempre possibilitam uma informação exata também, dificultando que o turista volte, ou até que chegue ao seu local almejado.

MAPA 5: Mapa turístico com exploração da implantação zonal

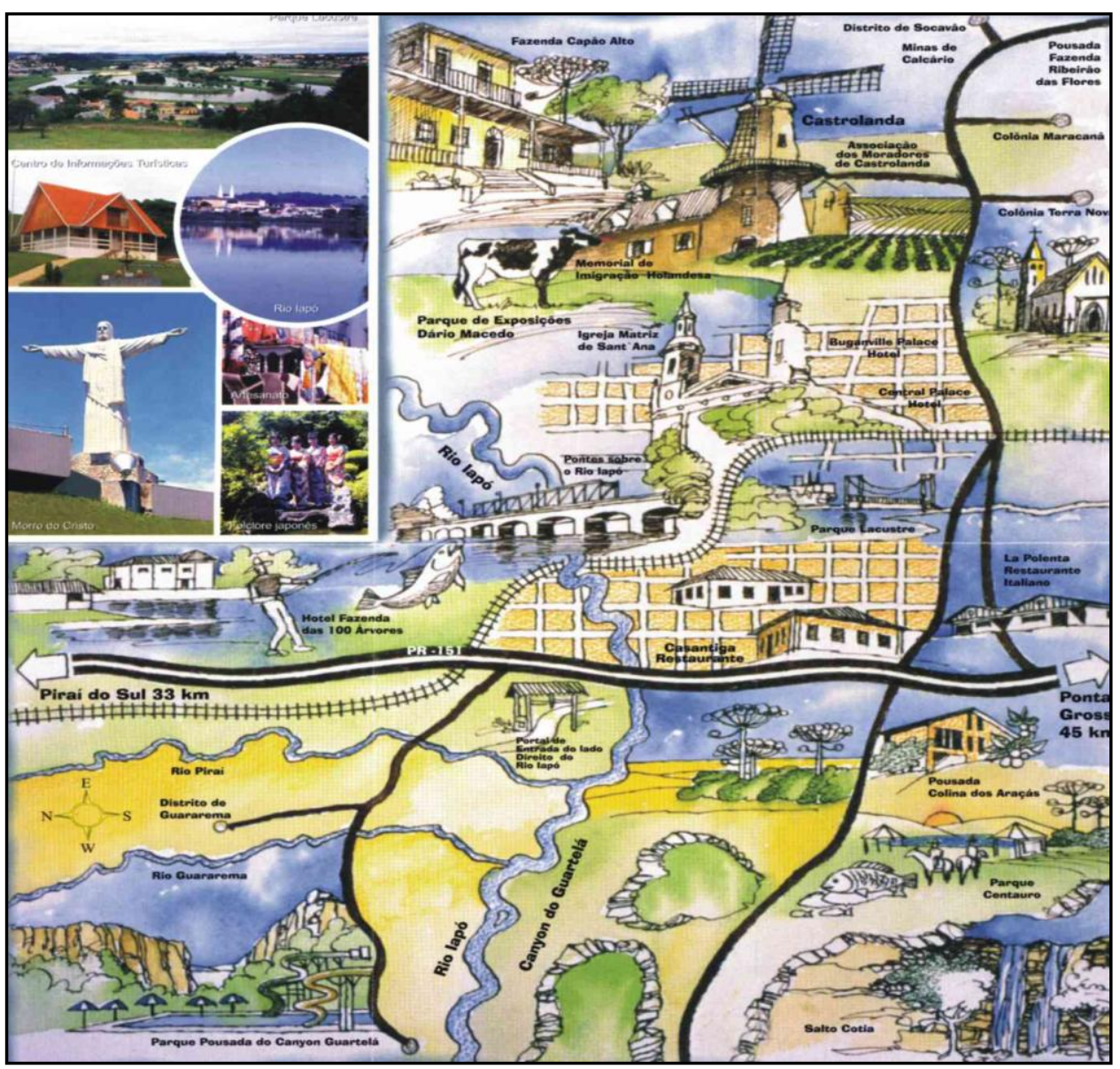

Fonte: CASTROTUR / Conselho Municipal de Turismo de Castro - PR 
MAPAS 6 E 7: Mapa turístico com encartes e hipertextos

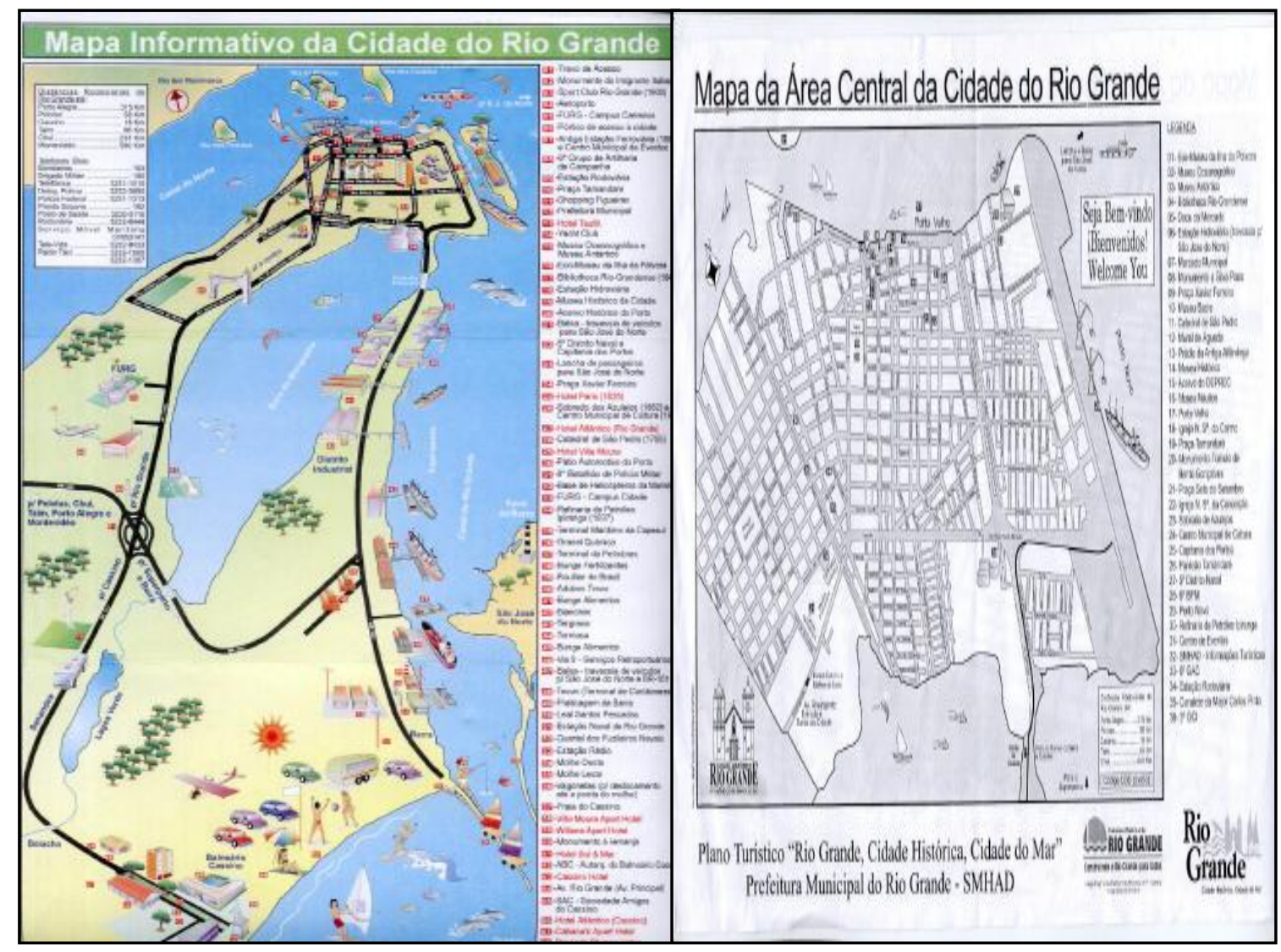

Fonte: Prefeitura Municipal do Rio Grande - RS. / SMTEL - Secretaria Municipal de Turismo,

Esporte e Lazer.

Estes outros mapa, 5 e 6, também com encartes e hipertextos, já expressam uma preocupação muito mais próxima do intuito cartográfico. Mesmo utilizando de simbologias pictóricas, traz a distribuição dos espaços de forma bem visualizável e com legendas detalhadas.

A poluição visual encontrada no mapa 4 já não se manifesta neste, que encontrou através do encarte uma maneira de descomplicar, ou seja, de facilitar a leitura. 


\section{Quanto à finalidade turística}

São alguns dos exemplos de finalidades turísticas que podem gerar diferentes tipos de mapa:

- Turismo Familiar

- Turismo de Elite

- Turismo de Mergulho

- Turismo de Compra

- Turismo de Natureza

- Turismo de Aventura

- Turismo Cultural

- Turismo Científico

Para cada finalidade o construtor de mapas deve selecionar as melhores variáveis e tipo de implantações que representam o desejado. Caso contrário a caracterização identitária do turismo pode ficar desfocada do alvo de interesse.

Muitas vezes, estes mapas, acompanham um agregado de informações necessárias ao turismo, o que não tira a necessidade de que a representação seja eficaz e bem feita. Na sequencia, são apresentados alguns exemplos de mapas turísticos com diferentes finalidades. O primeiro deles é muito comum, 0 mapa que representa o Turismo de Lazer, também chamado de turismo de sol e praia, um dos mais procurados pelos veranistas. Exige uma boa localização do espaço identificando os balneários e rotas de acesso. A escala é de vital importância, pois permite saber as distâncias entre os lugares. 
MAPA 8: Turismo de lazer também chamado de turismo de sol e praia.

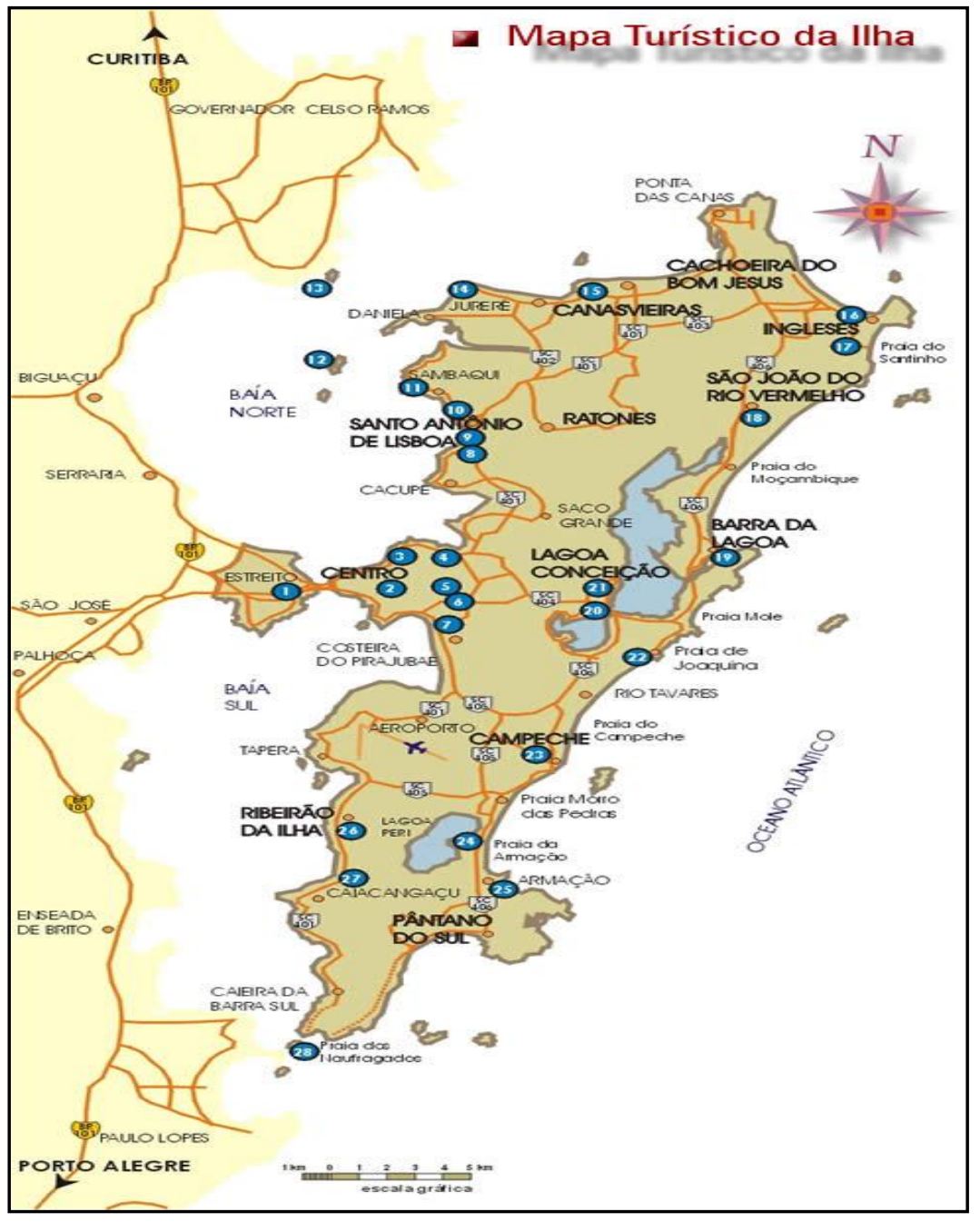

Fonte: Prefeitura Municipal de Florianópolis - SC

Diferentemente do mapa turístico de finalidade de lazer (mapas 4 ao 8), que geralmente é mais adornado por elementos pictóricos, alguns não convencionais, que promovem o lugar com ilustrações, muitas vezes, produzido ao extremo para atingir o imaginário do usuário e convencendo-o a visitar, o mapa voltado ao turismo científico (mapas 9 a 12), emprega geralmente um tipo totalmente diferente de simbologias, pois seus usuários requerem muita seriedade no material elaborado como mapa turístico, visto que, muitas vezes é utilizado como informação vital para determinados estudos. Então, não basta conter os 
requisitos essenciais de orientação e escala, por exemplo, se a legenda não estiver proporcionando uma leitura fiel dentro de uma cientificidade padrão.

FIGURA 9: Horizonte ilustrativo utilizado em turismo científico

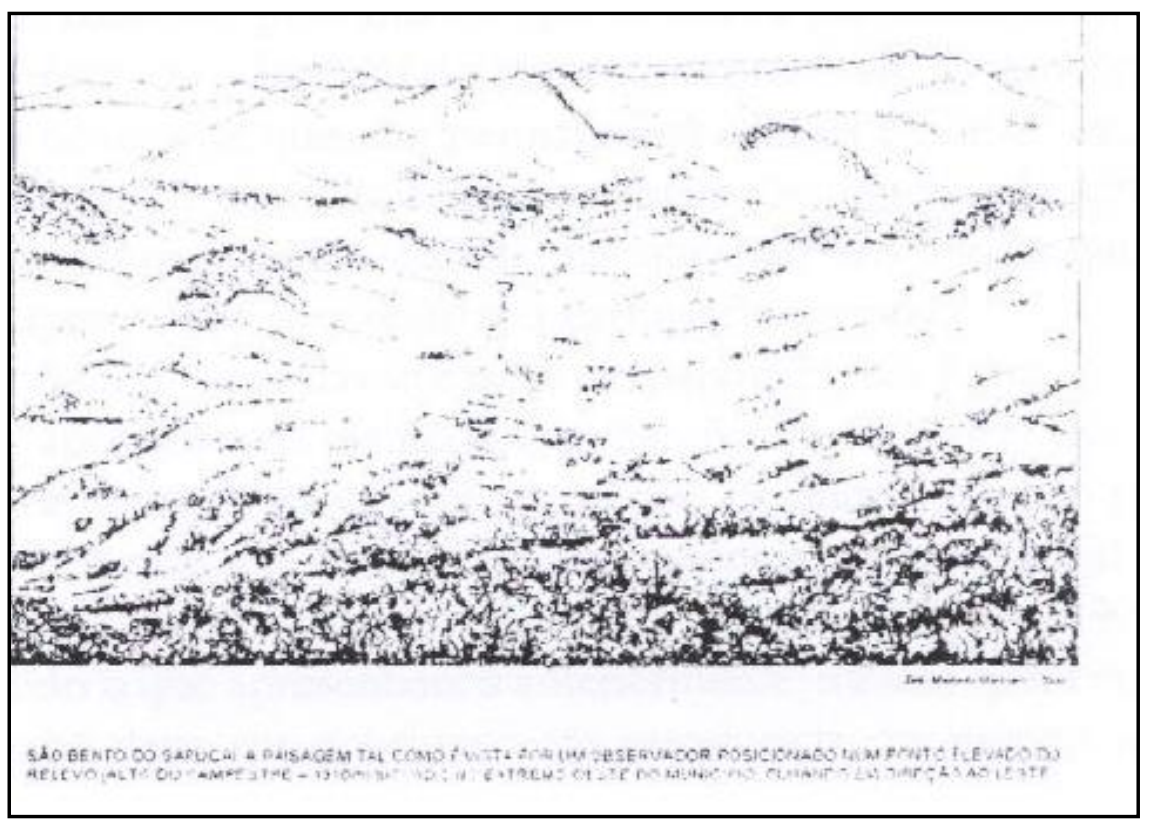

Fonte: MARTINELLI, Marcello. Cartografia do Turismo e Imaginário. In: RODRIGUES, A B. (org). Turismo rural: práticas e perspectivas. São Paulo: Contexto, 2001.

\section{Mapas 9, 10,11 e 12: Mapas de turismo científico}

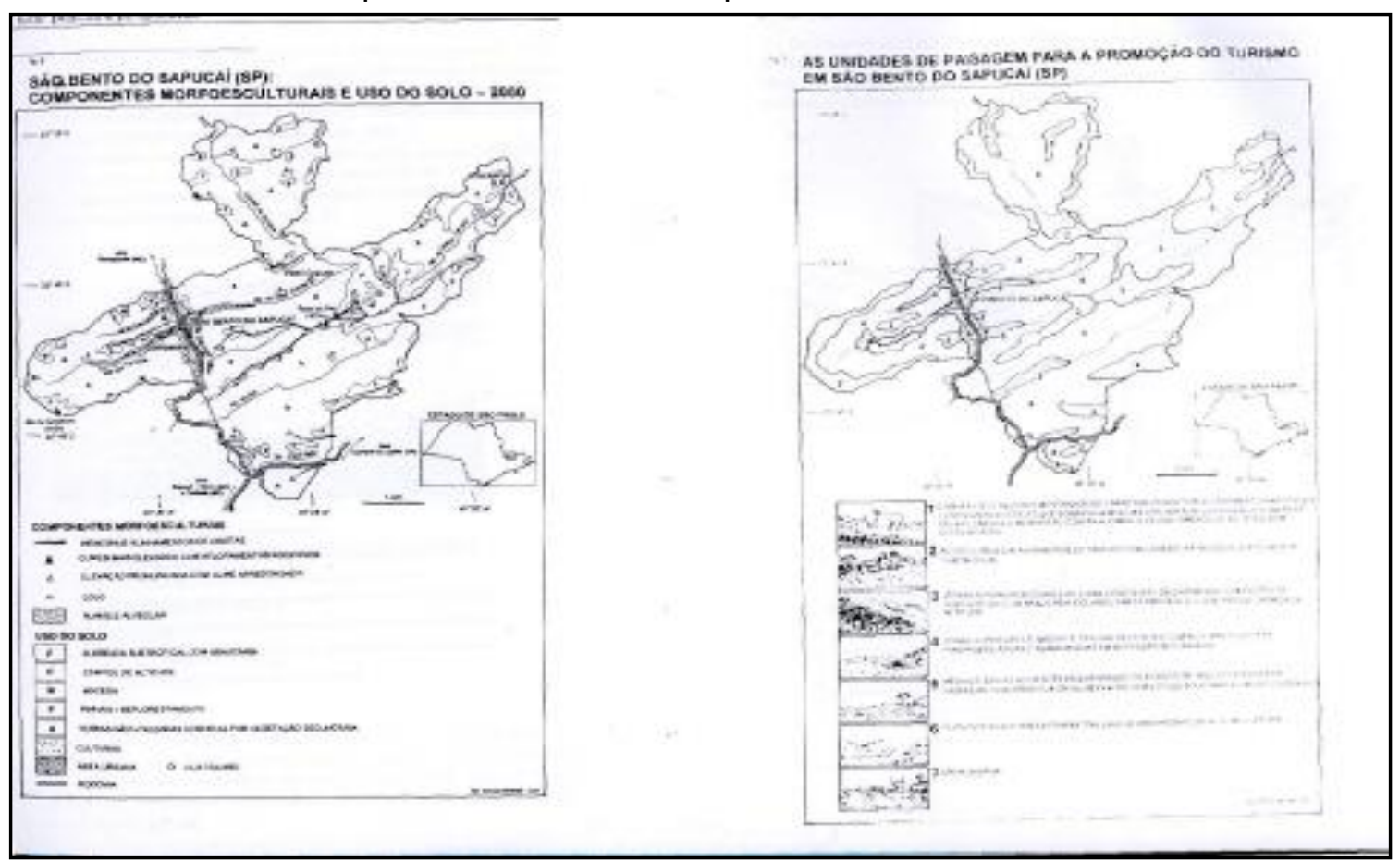

Fonte: MARTINELLI, Marcello.Cartografia do Turismo e Imaginário. In: RODRIGUES, A B. (org). Turismo rural: práticas e perspectivas. São Paulo: Contexto, 2001. 


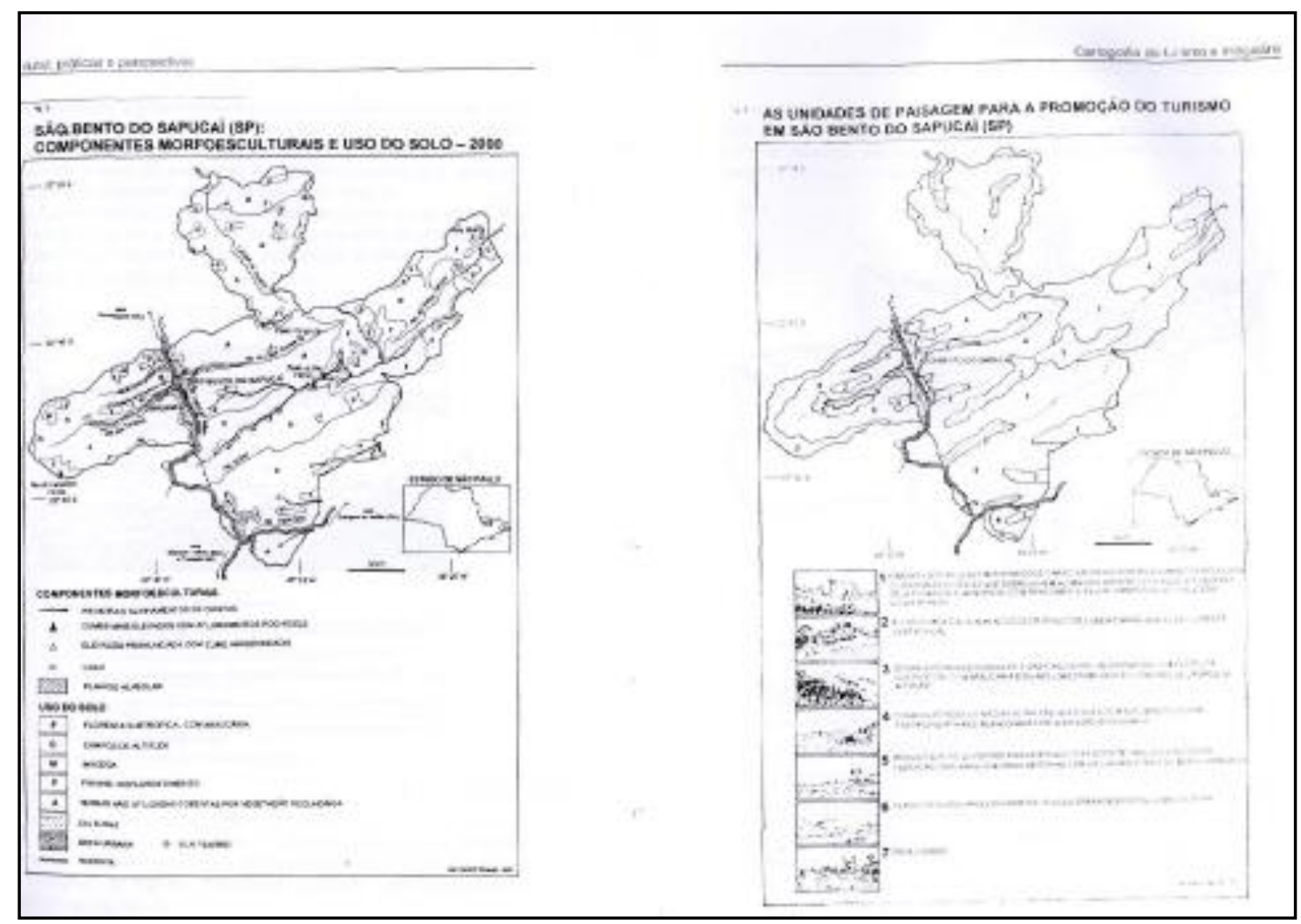

Fonte: MARTINELLI, Marcello.Cartografia do Turismo e Imaginário. In: RODRIGUES, $A$ B. (org). Turismo rural: práticas e perspectivas. São Paulo: Contexto, 2001.

Os mapas de interesse científicos são carregados, portanto, de referências informacionais de ordem acadêmica, retratando a cientificidade em todos os âmbitos. Comumente, estes tipos de mapa somente são encontrados e explorados juntos às universidades e órgãos ou institutos especializados e, servem para um elevado nível de pesquisa, planejamentos, e serviços. Assim, embora estes mapas também possam ser chamados de turísticos, porque são utilizados para uma espécie de visitação, os mesmos tem a visão de que esta atividade possui uma finalidade mais formal que propriamente de lazer ou do ócio e, nesse sentido, tais visitantes são muito mais exigentes e críticos. 
MAPA 13: Mapa com finalidade de ecoturismo

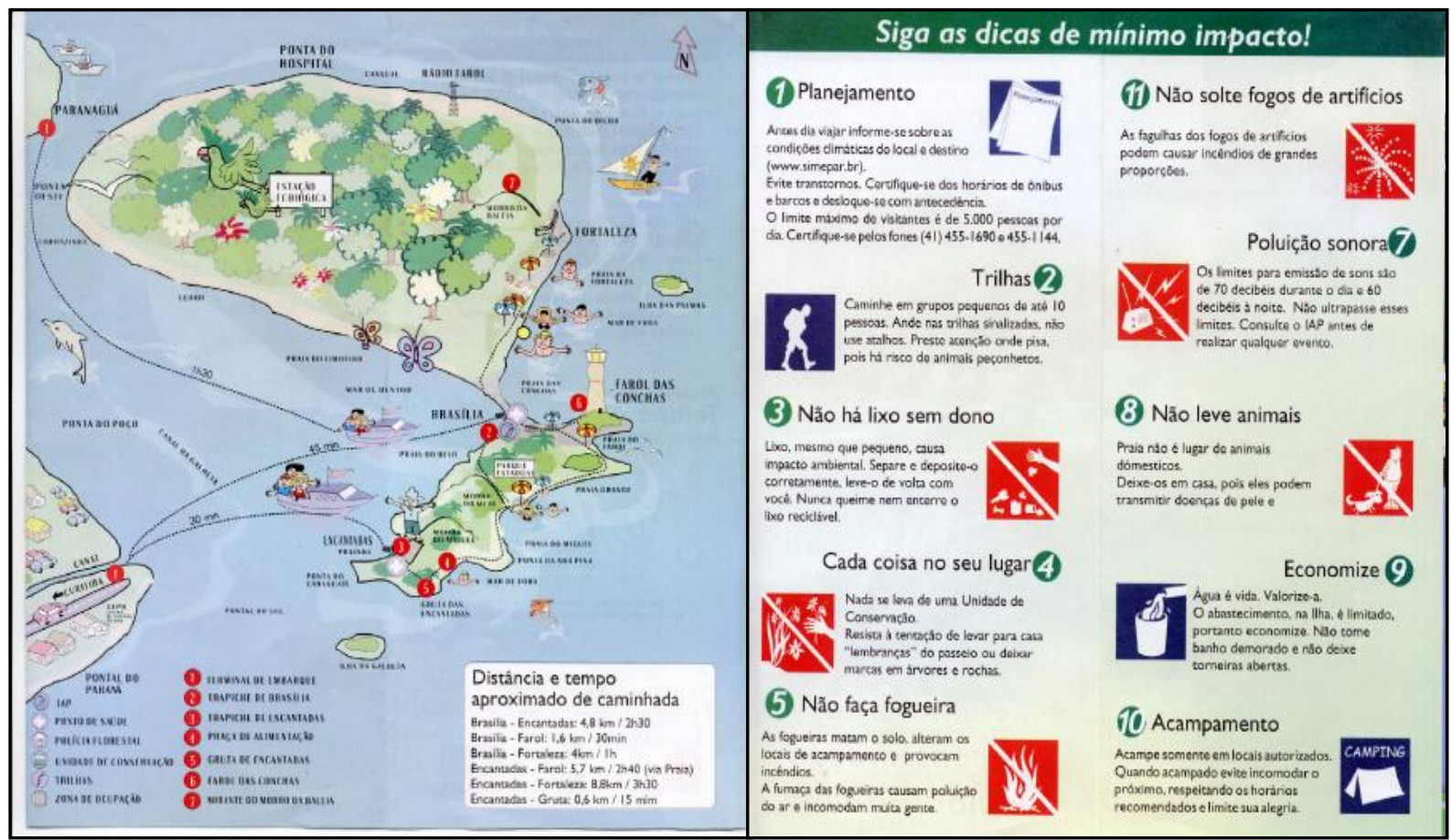

Fonte: Estado do Paraná / Secretaria de Turismo e Meio Ambiente/IAP _ Instituto Ambiental do Paraná

O mapa com a finalidade de Ecoturismo, trás além das informações científicas e/ou ambientais, um encarte com uma série de normas de comportamento naquele determinado espaço, em razão de prevenir os possíveis impactos que podem ser gerados com o processo de abertura para visitação em reservas e parques importantes.

Hoje o turismo rural também conquista seu espaço no mercado e utiliza-se do marketing informacional, com mapas turísticos em muitos deles. No entanto, na maioria, se atende mais a finalidade de reconhecimento da distribuição e organização dos espaços na área, geralmente fazendas. Isso favorece a não perturbação de comunidades residentes e fauna local, assim como no ecoturismo, para evitar efeitos impactantes de grandes proporções. 
MAPA 14: Mapa de turismo rural

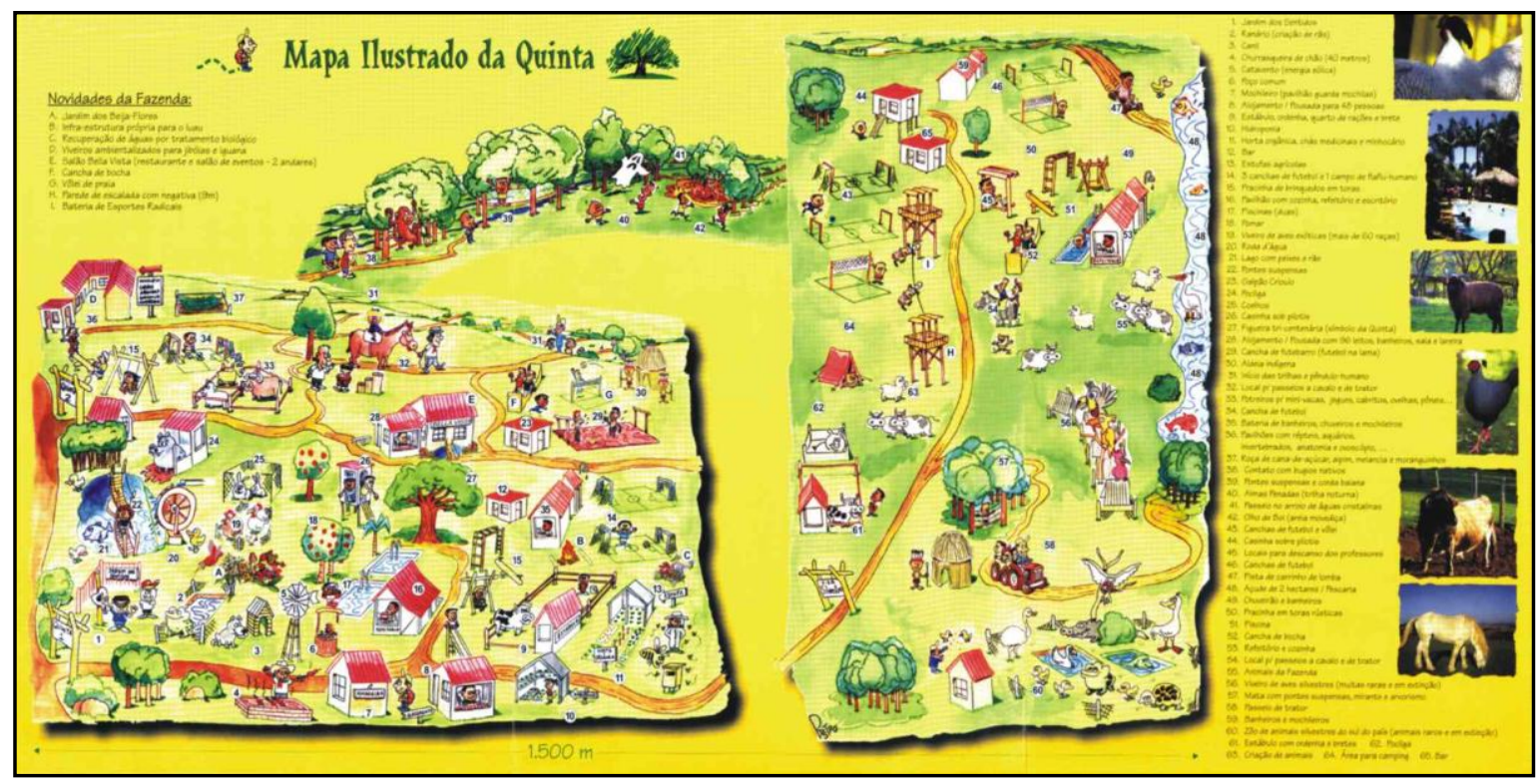

Fonte: QUINTA DA ESTÂNCIA, Folder Turístico. s/d.

No mapa anterior nota-se que foge completamente à ideia de coerência espacial, proporções dos elementos simbólicos, ou preocupação com variável visual. Ou seja, não possui nenhum critério cartográfico, é mais vinculado às artes gráficas, apresentando de forma artísticas os espaços reais. Como já foi dito, existe uma variedade de finalidade de Mapas turísticos, estes foram alguns escolhidos apenas para ilustrar esta breve explanação.

\subsubsection{Passos para uma representação temática adequada ao turismo}

Finalizando nossa discussão sobre a questão da cartografia temática aplicada a elaboração de mapa turístico, com a preocupação de adequação da simbologia, atendendo aos critérios vistos sobre as variáveis visuais e a 
importância desta semiologia gráfica para o processo de decodificação (leitura) do mapa pelo usuário, trazemos um exemplar de roteiro de elaboração de um mapa turístico elaborado pela Sociedade Suíça de Cartografia e adaptado por alguns estudiosos brasileiros para pesquisa junto à Universidade Estadual de Maringá. O mesmo é bastante interessante pela praticidade de entendimento e ao mesmo tempo pela cientificidade que geralmente fica muito esquecida nos mapas destinados a essa finalidade turística.

Figura 10. Passos para elaboração de um mapa turístico

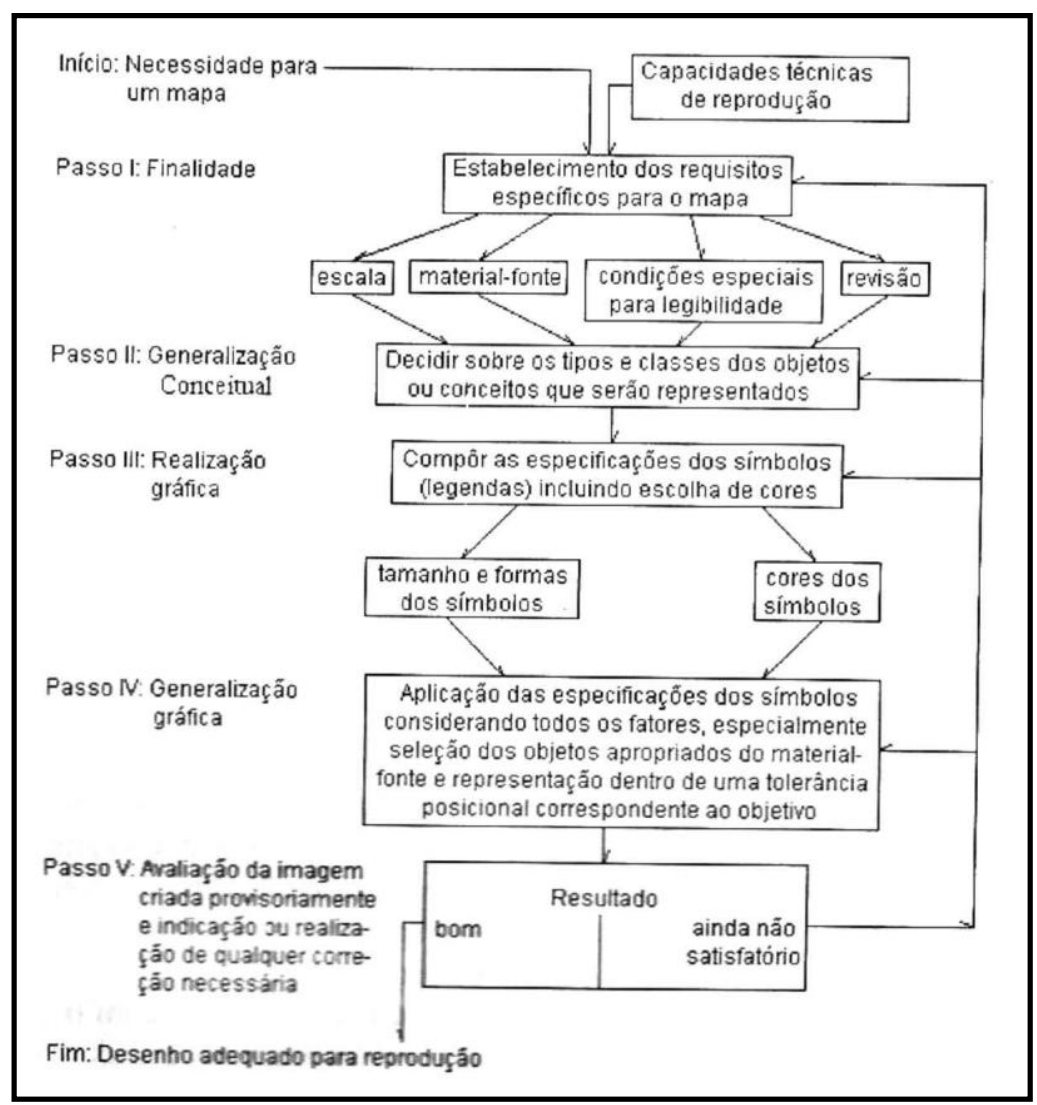

Fonte: Swiss Society of Cartography (1977) apud SANTIL, QUEIROZ e FREIRE (2002; 91).

Diante deste encaminhamento, percebemos que existem cinco passos a serem observados no momento de elaboração de um mapa turístico: 
Passo I: Finalidade

Passo II: Generalização Conceitual

Passo III: Realização Gráfica

Passo IV: Generalização Gráfica

Passo V: Avaliação da Imagem

Logo, se percebe que em primeiro lugar vem a finalidade do mapa, ou seja, o propósito do "para que" e "para quem" ele será produzido. Neste sentido se direciona o olhar para a paisagem, ou para o espaço a ser representado de modo a filtrar o que se deseja mostrar. É nesse sentido que ocorre também um processo de generalização conceitual, pois não se pode representar tudo e, nem tão pouco, informar tudo que está ali presente. Assim, direcionando o foco para o que se pretende, captam-se as informações que ocorrem em maior destaque ou intensidade, eliminando dados supérfulos, que não dizem respeito ao tema a ser exposto.

É claro que, já se demonstra que a representação cartográfica não é uma apresentação fiel da realidade. Em meios digitais, chamamos estes desvios de ruídos, onde se aceita certa margem de descompasso entre o real e o representado.

Após coletadas e selecionadas as informações, passa-se para o passo seguinte que é a representação gráfica, onde partindo de um mapa base (geralmente topográfico) faz-se a escolha da simbologia que melhor se adeque aos atributos a serem mapeados. Daí é que se percebe a necessidade de uma 
generalização e, muitas vezes, essa ação volta a se repetir neste momento de representar, pois encher um mapa de informações é considerado "poluir", o que comprometerá fortemente o processo de leitura e decodificação.

Mesmo após feitas as escolhas e atribuído a cada informação uma simbologia associativa, ainda não se pode acreditar que o mapa esteja perfeito. Novamente é exigida uma análise cuidadosa sobre o efeito produzido pela imagem. Se a mesma traduz de forma clara e objetiva (possibilitando uma leitura monossêmica) as informações pretendidas no início do projeto cartográfico. Ainda que muito trabalhoso com belas ilustrações e cores atribuídas, é hora de voltar ao início do processo, se o resultado não foi satisfatório. Pois, de nada adianta um produto atraente, com feitio rápido ou barato, se os efeitos pretendidos, que são os de atender a demanda do usuário, não foram alcançados.

Muitas são as situações de erro encontradas em mapas, talvez por descuido ou inexperiência do produtor cartográfico. Também, adicionamos as falsas produções que seguem interesses de macular um fato ou fenômeno para tirar proveito no destaque de outra informação. Tais questões, denominadas de "erros" e "mentiras" serão tratados no próximo capítulo, sob o olhar do geógrafo Mark Monmonier, que é o nosso horizonte no executar dessa tese. 


\section{CAPÍTULO 2.}

\section{ERROS E MENTIRAS CARTOGRÁFICAS}

\section{REVELADAS POR MONMONIER}

"O Mestre cria as idéias... os discípulos encontram as palavras" (minha inspiração baseada no grande mestre Monmonier)

Muito mais que um mestre cátedra inspirador, Monmonier é aqui seguido em nossos estudos por seu profundo conhecimento cartográfico e por sua brilhante arte de lidar com as palavras de uma maneira um tanto sutil, mas que nos remete a refletir criticamente sobre o nosso papel na ciência, bem como na influência de um trabalho bem ou mal elaborado, na formação de opiniões públicas e, até mesmo, na propagação de uma ideologia do poder. São conceitos e abordagens bastante recentes, que discutem a produção de mapas numa contemporaneidade digital dos dias de hoje.

Como que numa autobiografia Monmonier (2010) se descreve:

Ao contrário da maioria dos historiadores de mapa, me concentro no século $X X$, um período rico em histórias intrigantes, de propaganda enganosa e trauma tecnológico, mas pobres em coleções raras e caras como as que conduzem muitas vezes mais bolsas de estudo cartográfico, de períodos anteriores. Convencidos de que o que os cartógrafos fazem ou não nos afeta a todos, eu gosto do desafio de proporcionar 'insights' acessível para o leitor geral. (homepage de MARK MONMONIER acessada em 29 de abril de 2010.) 


\title{
2.1. Mark Monmonier e sua ampla abordagem teórica sobre cuidados
} cartográficos $^{12}$

\begin{abstract}
"Todo conceito é uma abstração que serve para identificar ocorrências do mundo real. $A$ ciência precisa ter um mínimo de clareza sobre os seus conceitos. Quanto mais precisos forem os conceitos, melhor será para a compreensão".
\end{abstract}

(CERVI 2009; 9)

\subsubsection{O mapa enquanto símbolo de poder}

Antes de tudo, é preciso lembrar que o mapa carrega consigo uma ideologia, independentemente de quem o produziu e a quem servirá.

\footnotetext{
${ }^{12}$ Os estudos de Monmonier são tão pertinentes que seus livros se encontram no mercado mesmo após longo tempo de publicação, além de serem quase que leituras obrigatórias em cursos universitários. Geralmente seus escritos versam sobre questões sobre o impacto da Cartografia na Sociedade. "How to Lie with Maps" é considerado um "best seller" na categoria de ciência geográfica, e é publicado em seis idiomas (inglês, francês, japonês, coreano, alemão e checo).
}

Figura 11: Foto de livro de Mark Monmonier

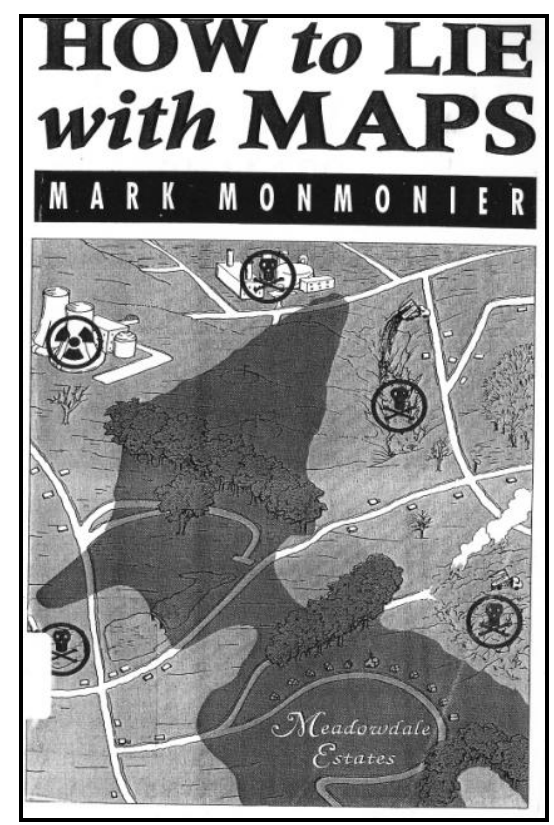


Frequentemente essa ideologia está atrelada aos interesses das classes de poder, representadas pelos chefes de Estado (ou seja, pelos interesses políticos de uma nação), pelo controle militar, pelos agentes de marketing e propaganda, pelos detentores dos meios de produção, pelos proprietários e grandes especuladores imobiliários.

Figura 12. Selos argentinos, propagando a soberania da nação através de mapas ilustrativos.

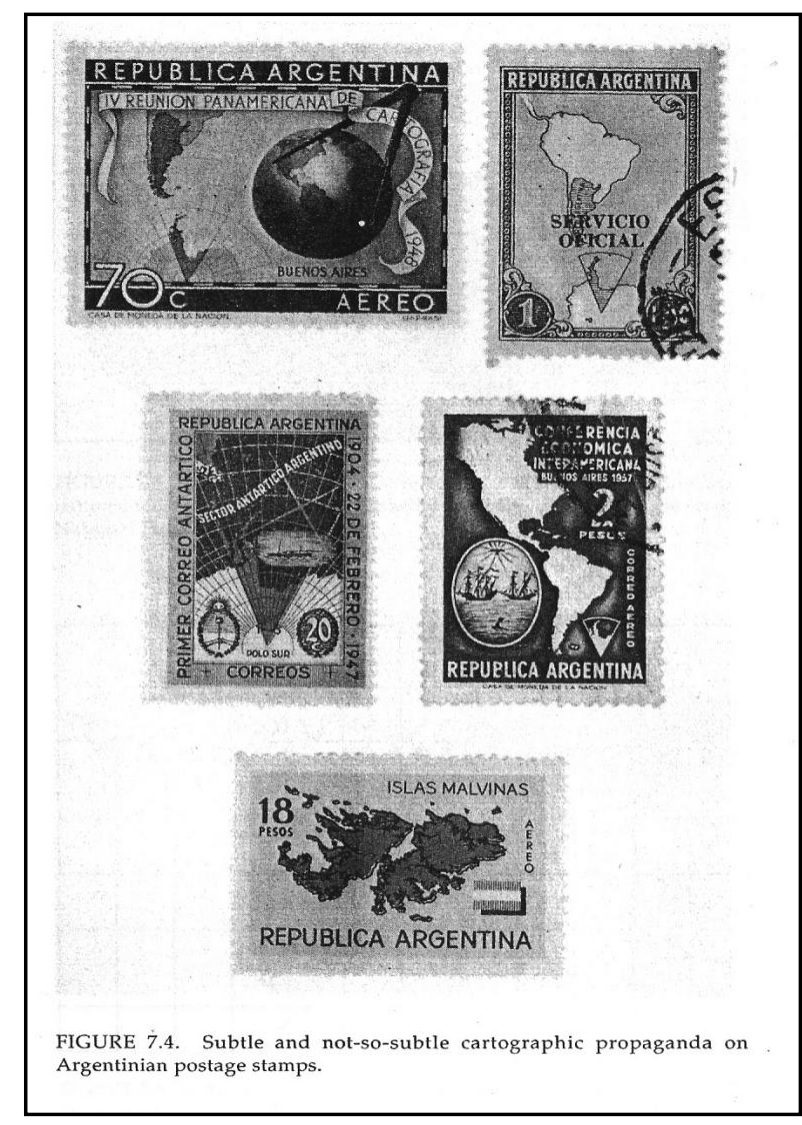

Fonte: MONMONIER, Mark. 1991; 93.

Assim, o viés ideológico diante dos diferentes eventos ocorridos no decorrer da história está presente também no agir da Cartografia enquanto instrumento de pesquisa e prática profissional e, desse modo, traz consigo um 
propósito, ainda que camuflado e, repercute com certo impacto nos usuários, representados aqui como todos os cidadãos, sejam eles cultos ou leigos.

Poderíamos rever até o próprio início da cartografia, no escolher das projeções, que por mais que, por si só tragam distorções geodésicas, o que tem maior influência na seleção de qual se adotar é aquela que dá ênfase no território que tem o interesse, daí o motivo da maioria dos mapas-mundi trazer a Europa ao centro, como polarizadora do estante do mundo.

Figura 13. Projeções Cartográficas

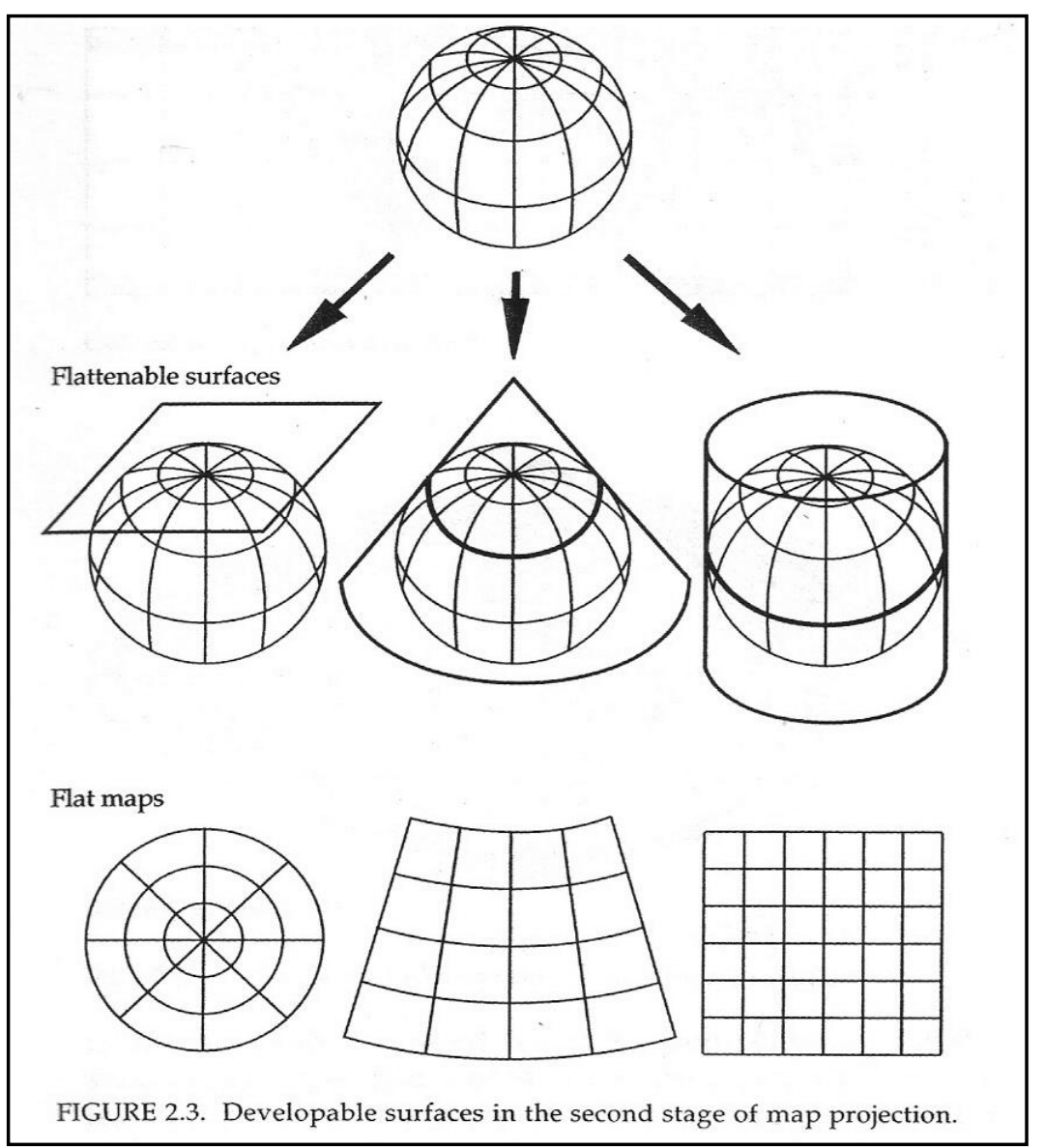

Fonte: MONMONIER, Mark . 1991;10 
Lacoste (1988), neste mesmo sentido, vem a afirmar em seu livro "A Geografia - Isso Serve Antes de Mais Nada, para Fazer a Guerra", que é preciso conhecer o espaço para saber nele se organizar. Quem conhece o espaço em sua plenitude, praticamente detém o poder em mãos, assim, o saber cartográfico passa a ser concebido como uma ferramenta de dominação. Monmonier confirma isto, na publicação de "How to lie with Maps", salientando que mapas elaborados por diplomatas e generais muitas vezes demonstraram uma realidade política que impõe certa ironia involuntária ao aforismo: a idéia de que "a caneta é mais poderosa que a espada". Tais considerações também são salientadas por Wood e Fels (1992) no livro "The Power of Maps" (O poder dos mapas).

Figura 14: Mapa estratégico ilustrado em Jornal

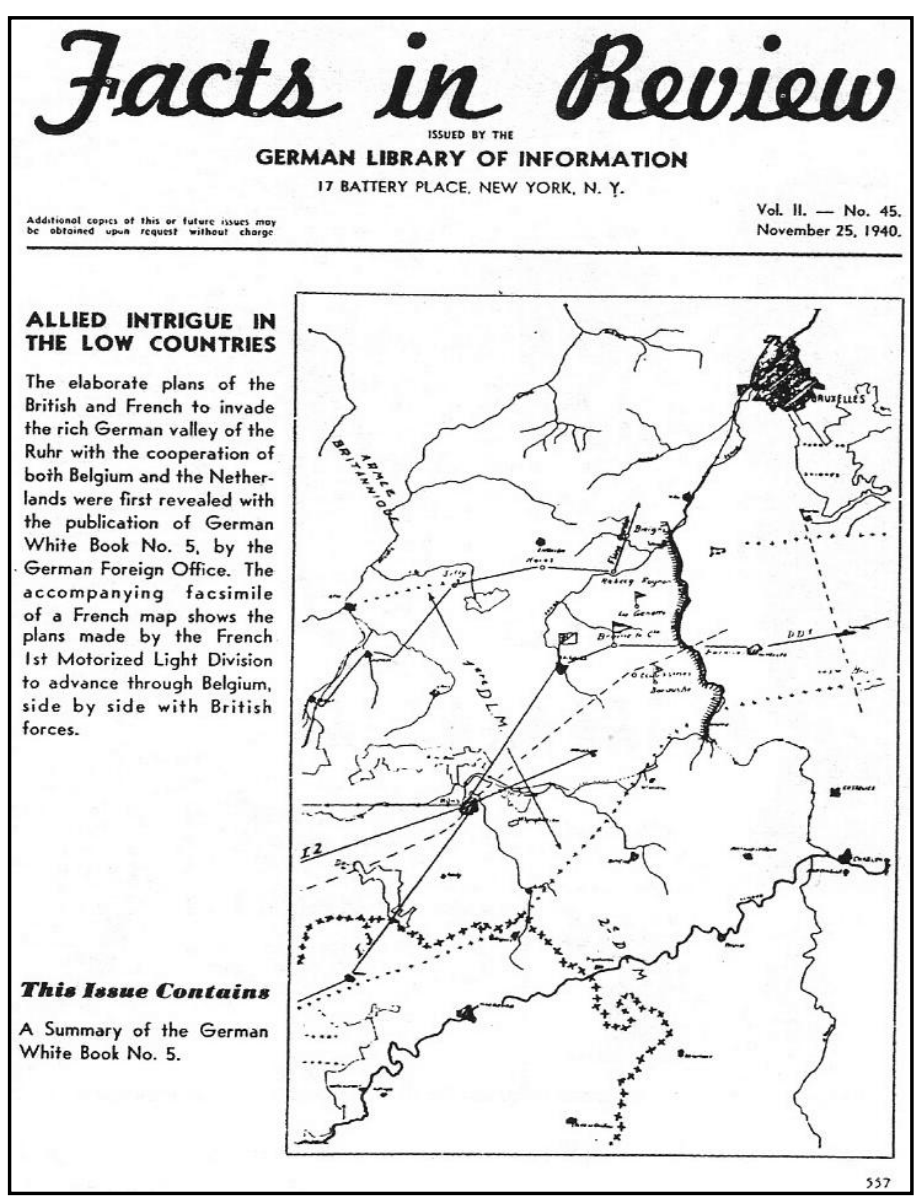

Fonte: MONMONIER, Mark. 1991;104. 
Os mapas informam, localizam e permitem elaborar estratégias de

dominação e ataques militares em ocasiões de guerra. Estes podem trazer grande precisão dos pontos focalizados por aqueles que estão no controle, no poder, no desígnio de uma ação precisa; porém, os mesmo em alguns casos, tem o intuito de dispersar a atenção sobre um assunto específico em ocorrência na localidade, dando maior ênfase em outra temática, ou utilizando simbologias representativas que mais confundem e poluem a leitura, que permitem ou facilitam a aquisição de informações espaciais, conforme afirma Wood e Fels $(1992 ; 70)$ "O intuito do mapa é mascarado ${ }^{13 ”}$ (tradução nossa).

Uma das coisas que Monmonier (2007) enfoca em seus estudos, como manifestação ideológica é o efeito pejorativo ${ }^{14}$ de algumas toponímias utilizadas nos mapas, termos que expressam preconceitos, vulgaridades ou retratam termos

\footnotetext{
13 "The Interest the Map Serves is Masked". Nesta mesma página os autores fazem menção ao livro "How to lie with maps", de Mark Monmonier.

${ }^{14}$ a palavra "squaw" originou-se entre os comerciantes franceses como uma corruptela da gíria indiana de vagina, um comerciante que queria uma mulher para a noite, pediu uma squaw. Colonos brancos aplicaram o termo de forma imprudente a centenas de montanhas, rios, lagos, cânions e outras características topográficas em todo o oeste americano [...] Embora a conotação negativa de uma prostituta escrava sexual aparentemente evoluíram após o prazo passou para o Inglês no século XVII, para muitos americanos brancos squaw foi e ainda é apenas uma palavra neutra, conveniente de uma sílaba, para a mulher indiana. Que muitas (se não a maioria) os índios americanos encontrar a palavra desagradável parece mais profundamente enraizada no tratamento muitas vezes brutal da maioria branca, de indígenas norte-americanos. (tradução MONMONIER, 2007;2 - 3)
}

Aqui poderíamos fazer uma correspondência ao emprego do nome "Buraco do Padre" à um dos pontos turísticos mais significativos do município. O mesmo caracteriza-se por uma beleza natural, na formação de uma espécie de anfiteatro rochoso de grande dimensão, do qual cai do alto, uma enorme queda d'água, formando um poço raso, uma espécie de praia, onde os visitantes costumam tomar banho. O termo pejorativo hora atrai e hora espanta os turistas, fazendo ainda criarem novos adjetivos a lugares citados como "Fenda da Freira", porém desconhecido a todos... logo, percebe-se que trata apenas de uma crítica humorística ao nome do local em questão descrito aqui. Pois na realidade o nome é justificado pela grande presença de padres jesuítas nos tempos primórdios do município, que iam até a localidade para fazer meditação. 
regionais pouco conhecidos pela maioria da população, sendo, portanto uma ofensa à suas condições de compreensão.

Nesse sentido, o autor convida os usuários a participarem desse processo através de uma leitura e revisão crítica dos materiais que são produzidos e a ajudarem a cobrar esta revisão técnica dos responsáveis.

Salienta o mesmo, quanto à luta de crenças religiosas, grupos feministas, demais classes de interesse e, até o governo local, para solicitar algumas mudanças nos termos empregados, porém há uma dificuldade muito grande diante disso, pois é bem complicado encontrar uma palavra aceitável a todos que possa substituir, sendo que também, em muitos casos necessita passar pelo consentimento de "Conselho de Nomes Geográficos".

Figura 15. Transição de toponímias empregadas nos mapas

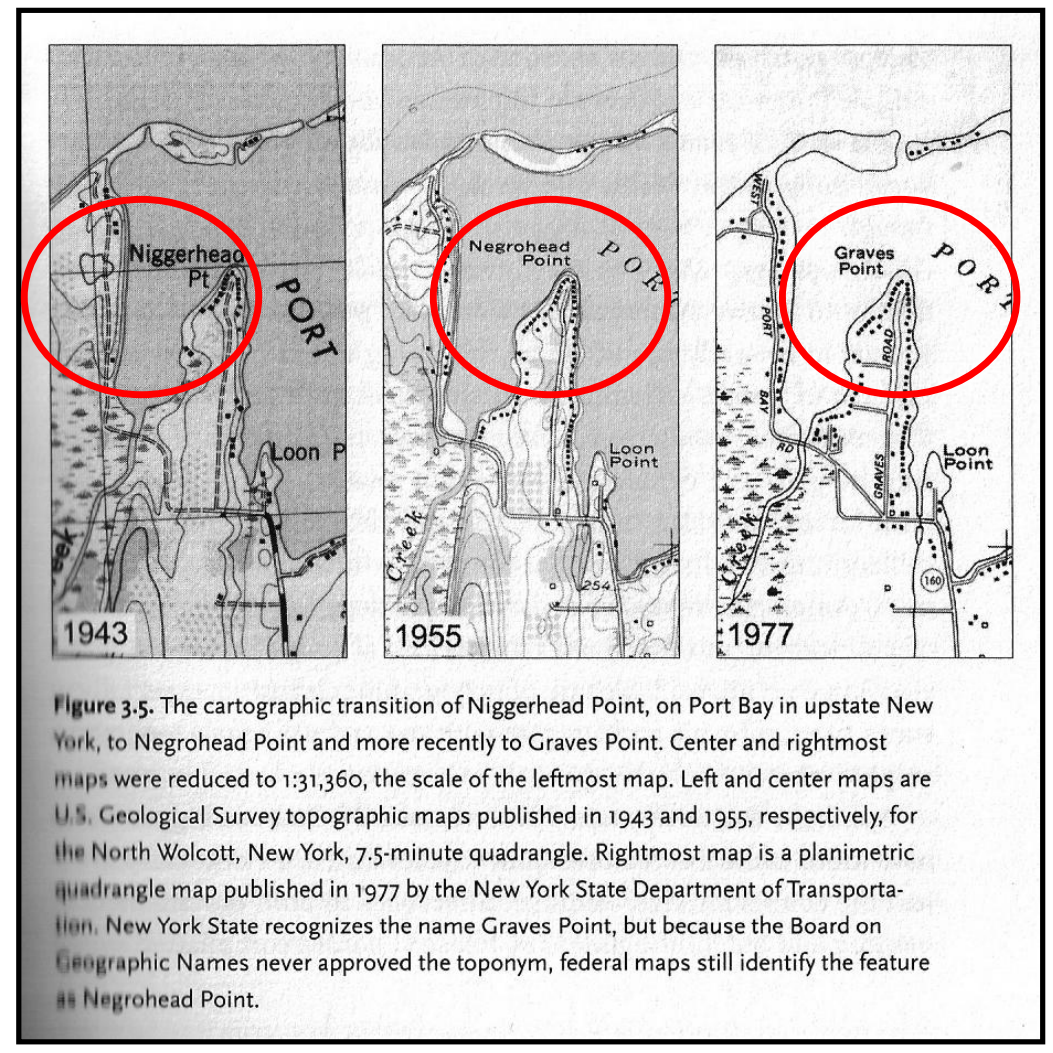

Fonte: MONMONIER, Mark. 2007; 51 (destaque nosso) 
A figura anterior ilustra uma região de Nova York que com o passar do tempo foi recebendo outras denominações, por ter a princípio se defrontado com a rejeição social quanto a toponímia empregada na representação cartográfica da localidade.

Atentando a esta observação é possível perceber que a forma de criar metáforas simbólicas ${ }^{15}$, para as informações, embute também, representações de poder de um território, causando interpretações errôneas forçadas por tendências mais significativas na representatividade espacial.

\subsubsection{Os erros propositais e os erros acidentais em mapas}

O grande chamariz dos estudos de Monmonier é afirmar que "os mapas mentem", discorrendo toda a sua retórica, de modo divertido, apresentando exemplos de situações em que isso acontece e porque acontecem. A mentira muitas vezes é necessária, segundo ele, e a verdade suprimida, para fazer o usuário ler no mapa o que precisa ser lido.

Para Monmonier (1996) alguns mapas muitas vezes falham devido à ignorância dos mapeadores e, um erro não é o mesmo que uma mentira, pois o erro está ligado à capacidade técnica dos produtores da representação

\footnotetext{
${ }^{15}$ Vila Velha, que é o ponto turístico mais conhecido em Ponta Grossa (nosso recorte espacial de pesquisa) seria talvez uma espécie de metáfora simbólica, pois só entenderão esta atribuição do nome quem souber da lenda indígena que retrata Vila Velha como Abaretama, uma antiga aldeia indígena, que fora petrificada por uma maldição do Deus do Trovão, recebendo depois disso o nome de Itacueretaba.
} 
cartográfica, e meios empregados para o mesmo fim, enquanto a mentira, está ligada a intenção do que se pretende que seja lido.

Salienta o autor, que assim como acontece em outras áreas, a maioria dos produtores de mapas ligados à órgãos governamentais e empresas comerciais, que não estão ainda licenciados na profissão de cartógrafos, e nunca sequer esteve estudando na academia, qualquer coisa ligada à Cartografia ou Geografia. Sendo assim, dá para se compreender o porquê de tantos erros técnicos, além de enganos inescrupulosos.

Sintetizando os diversos problemas, Monmonier salienta:

Os mapas têm três atributos básicos: escala, projeção e simbolização. Cada elemento é uma fonte de distorção. Como um grupo, eles descrevem a essência das possibilidades e limitações do mapa. Ninguém pode usar mapas ou fazer mapas com segurança $e$ eficazmente sem compreender escala de mapa, projeções de mapas e símbolos de mapas (1996).

Os erros mais preocupantes nos mapas incluem as escalas gráficas que levam os usuários a estimativas irreais das distâncias. Também destaca que muitos mapas são baseados em fontes incompatíveis, apresentam incorretamente os nomes de lugares e, ainda símbolos com tons de cores alterados pela impressão fraca ou até por um mau planejamento.

Ressalta, ainda, a habilidade dos mapas mentirem diante de estatísticas (caso muito frequente quando se trata de interesses eleitorais). Nesta questão, percebemos em veículos de imprensa, uma série de materiais estatísticos sem 
escrúpulos, mapas, tabelas e gráficos que induzem de forma nada ingênua a uma interpretação francamente enganadora. Também são espécies de mapa com finalidade muito mais voltada à propaganda (falsa), porém, não explorada e aprofundada aqui, por não ser nosso assunto em questão.

Salienta o autor que, o usuário ao buscar uma mapa como fonte de informação, deve estar ciente das falhas cartográficas, até mesmo dos pequenos erros. Na defensiva dos mapeadores, ele argumenta que os mesmos são humanos e, portanto, também erram.

Fica claro que, ao mesmo tempo em que Monmonier chama a atenção para a responsabilidade de tais produtores de mapas, e para os abusos que se cometem em algumas espécies de representações cartográficas, por outro lado, ele não pode ser acusado de ser cegamente taxativo, pois o mesmo reconhece as circunstâncias de dificuldade científica e técnica, bem como, as limitações humanas.

A seguir, apresentamos uma espécie de mapa turístico de Ponta Grossa $\mathrm{PR}^{16}$, nosso recorte espacial de pesquisa, para demonstrar alguns destes erros e incoerências referente a escala, que embora não apresentada de forma gráfica ou numérica, está expressa através das identificações em quilometragens nos trechos ilustrados.

\footnotetext{
${ }^{16}$ Adotamos um exemplar referente à nossa localidade para melhor ilustrar as idéias de Monmonier, visto que o mesmo traz em seu livro exemplos internacionais, e acreditamos que a ilustração com nossa realidade brasileira permite maior visibilidade das questões concretas aferidas. Neste sentido, buscaremos repetir essa prática no trabalho, ou seja, ilustrar o máximo possível com as localidades pertinentes à nossa natureza, brasileira, e se possível até paranaense e pontagrossense.
} 
Mapa 15 - Ponta Grossa - Localidades Turísticas

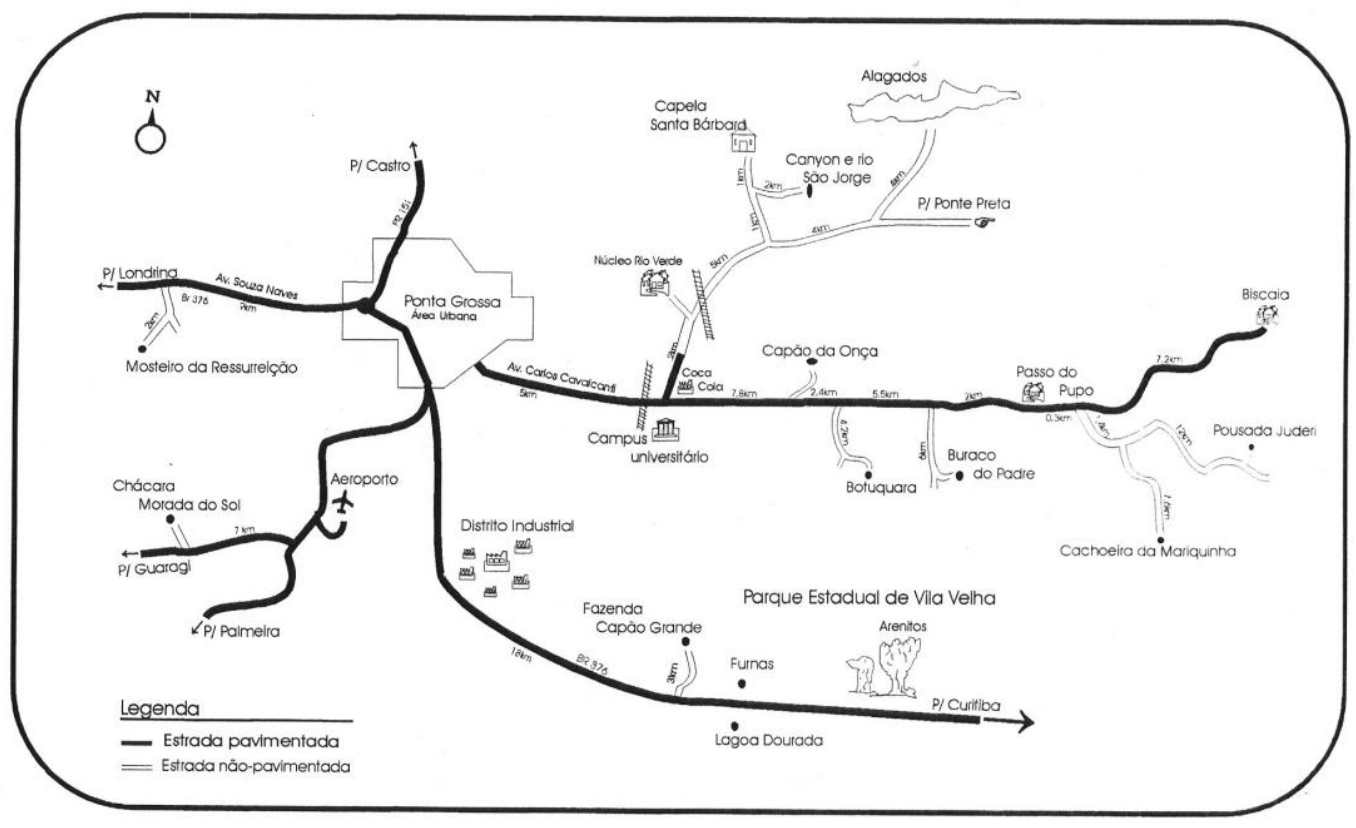

Fonte: Secretaria de Turismo de Ponta Grossa

Embora o mapa base, construído previamente para a finalidade de ser reproduzido em folder turístico tenha sido feito à um certo tempo (talvez mais de dez anos), atualmente se utiliza da mesma representação errônea, que não submete uma informação correta ao usuário do mesmo. Ou seja, se hoje há tantos recursos tecnológicos para atribuir maior precisão às representações cartográficas, porque se admite ainda erros banais baseados em simples amadorismo de mapeadores que ilustram hipoteticamente uma informação tão importante?

Não descartamos a consciência de que, vários fatores impedem um mapeamento exatamente fiel à realidade, mediante circunstâncias de necessidade de generalização, alterações de escala e atendimento a todos os 
propósitos demandados, no entanto, não se pode usar destas desculpas para reproduzir em grandes números, um material requisitado para (des)informação.

Diante disso, compreendemos que, mesmo com todo avanço tecnológico que tenta corrigir as possíveis desproporções, as informações apresentadas jamais corresponderão a $100 \%$ de exatidão, apresentando apenas grandes probabilidades de acertos, exigindo-se um mínimo de $85 \%$ de correspondência aos dados, conforme determinam os padrões internacionais. Para tanto, se checa em campo e, também, se realizam operações que chamamos de pósprocessamento.

Concordamos com Monmonier ao afirmar que a maioria dos grandes erros é causada pela combinação de desatenção e edições inadequadas. Sendo que tal descaso, encontra-se por sua vez num interesse mais focado no salário a se receber do que no trabalho a se produzir e, não havendo controle nem revisão acaba sendo inevitável a ocorrência de erros indesejáveis, que acabam por rotular de má qualidade o material elaborado.

As agências de mapeamento governamental, frequentemente garantem maior credibilidade em seus mapas, devido a total estrutura burocrática que exige eficiência controlada. Nesse sentido, os mapas topográficos, ou mapa base, que tem seu uso de forma mais expansiva, se tornam os mais entediantes de se elaborar, pois o rigor ainda é bem mais apurado.

Desse modo, os erros são mais comuns em mapas derivados, visto que tais mapas são compilados de outros mapas, que por sua vez já são mapas compilados através de fotos primarias ou outros dados primários. Isso se torna 
muito problematizador, quando o mapa não é feito por um geógrafo e sim por um operador de software, "designer" ou artista gráfico, visto que o mesmo não será capaz de identificar distorções importantes que devam ser revistas diante de algumas compilações.

Os artistas gráficos que atuam também neste ramo de produção de mapas carecem de treinamento cartográfico e apreciação de detalhes geográficos ao desenharem a maioria dos mapas, como por exemplo, os de caracteres turísticos e novos mapas temáticos, pois, observa-se que estes profissionais mal conhecem técnicas para elaborarem os mapas de ruas americanas (MONMONIER, 1996).

A profissionalização e a responsabilidade com o ato de produzir um material de informação e comunicação como o mapa deve acompanhar o ritmo da tecnologia, para fazer dessa modernidade, realmente, um privilégio a favor da ciência e das práticas sociais.

\subsubsection{Tecnologias e Táticas no mundo da Cartografia}

Enormes foram os avanços em termos de recursos técnicos e tecnológicos que esta ciência conheceu principalmente na segunda metade do século $X X$. $O$ autor Mark Monmonier enfatiza tal contribuição, associado à outros autores do campo científico internacional, destacando a grande influência do computador na produção cartográfica contemporânea e os recursos de sensoriamento remoto e geoprocessamento que facilitaram, em muito, o trabalho do construtor de mapas, bem como a maior aproximação de fidedignidade com o espaço representado. 
Figura16. Satélites captando imagens da superfície terrestre

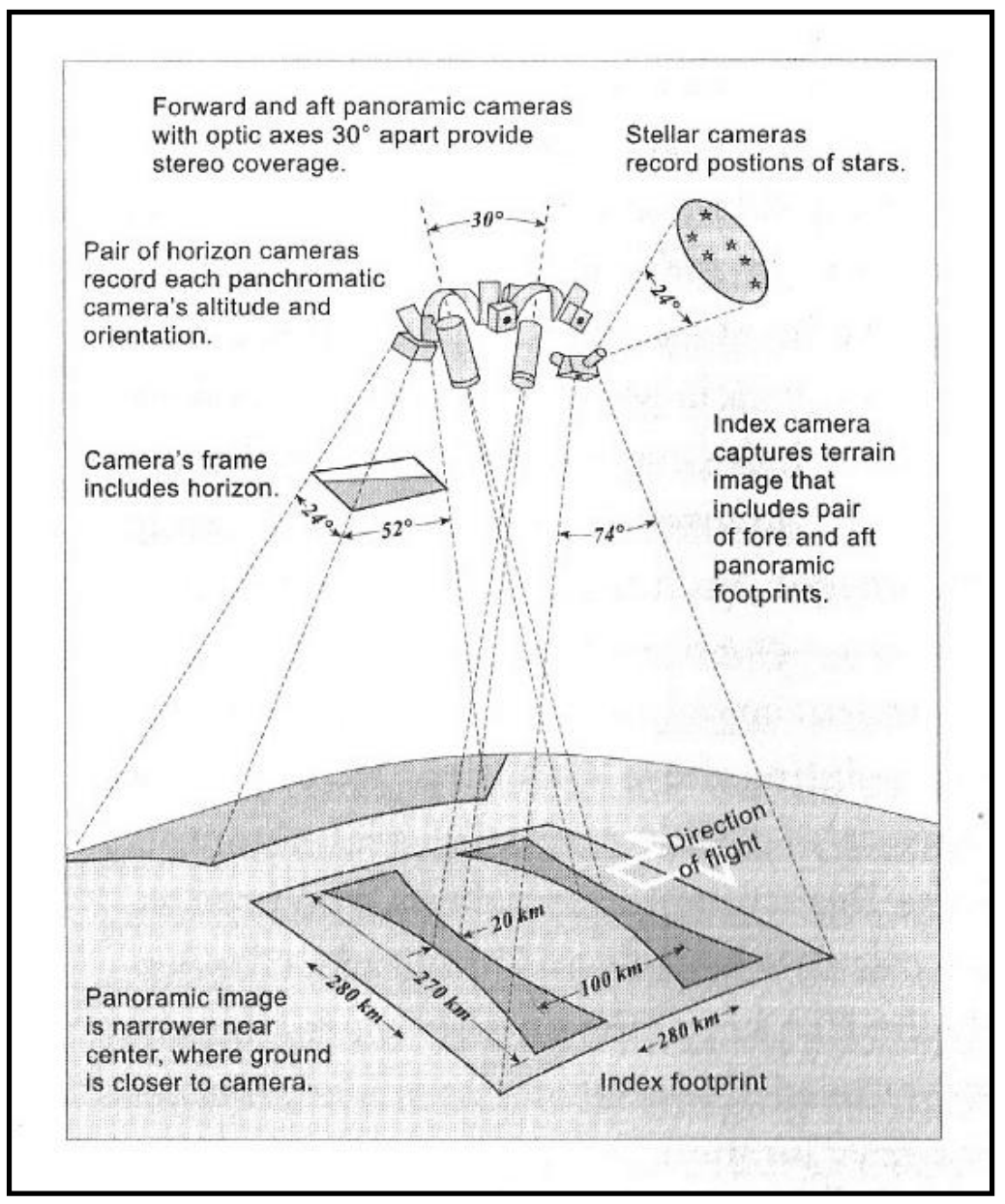

Fonte: Monmonier (2002;26)

Em nosso arcabouço teórico em Monmonier, vislumbramos, da mesma forma, a grande facilidade de mentir com mapas, pois com a informatização do mundo contemporâneo, os cartógrafos tendem à utilizar o sistema para a sua necessidade de generalização de muitos dados e nem percebem que caem numa verdadeira armadilha cartográfica, e, que os seu leitores, vislumbrando mapas com informações falsas, não compreendem o processo que causou tal distorção. Com isso, ao não conseguirem fazer o uso pretendido dos mapas, passam a se 
tornar céticos diante da cartografia, ou como afirma Monmonier (1991) adotam uma patologia conhecida como "cartofobia".

Se por um lado a informatização computacional facilitou o trabalho dos produtores de mapas, por outro os softwares de mapeamento encontrados no mercado e mesmo disponibilizados na internet permitiram uma utilização abusiva destes recursos, fazendo com que qualquer um se achasse na capacidade de exercer tal tarefa, mesmo em nível profissional, sem qualquer capacitação afim.

Explica Monmonier que com o espantoso crescimento de uso de computadores pessoais e com a democratização de publicações eletrônicas, inclusive mapas, imagens e recursos vinculados à Cartografia, tornou-se mais problematizadora a questão dos erros, pois os usuários podem facilmente mentir para si e nem estarem cientes disso.

Salienta ainda o autor que, antes do computador pessoal, a cartografia popular consistia basicamente de desenho à mão livre, que davam sentido aos mapas, pois o mapeador possuía controle total sobre o lápis e papel e geralmente tinha dificuldade em transferir rotas, marcos de referência e outras lembranças relevantes da mente para mapear.

O computador permite que programadores, especialistas em marketing e outros profissionais intermediários anônimos, sem relevância com a área cartográfica influenciem fortemente na aparência do mapa, pois desenvolvedores de softwares tornou fácil para leigos atuarem neste campo, que fazem do meio tecnológico um sacerdócio, selecionando com isso projeções inadequadas e um conjunto de símbolos enganosos, que resultam em graves mentiras cartográficas, 
que por sua vez, aparentemente se passam por informações respeitáveis e precisas. Monmonier denomina isso como sendo "asneiras eletrônicas utilizadas por ignorantes cartograficamente".

Os cursos universitários com formação em produção de mapa, diretamente relacionado à cartografia, ou à geografia, apresentam a distinção fundamental entre uma verdadeira produção científica e profissional de um material gráfico ${ }^{17}$, e a artimanha especulativa de alguns talentosos designers (artistas gráficos) que se arriscam a "construir mapas". A (des)informação destes, se reproduz naqueles que fazem uso deste material, comprometendo para a massificação da descrença nos mapas, e o desenvolvimento da "cartofobia".

Monmonier explica que estes ditos "produtores de mapas", sem capacitação técnica, fazem uso de ilustrações e comandos informatizados que não são atrelados à simbologia própria do fazer cartográfico, e tais usos simbólicos alternativos são desajeitadamente aplicados em materiais gráficos diversos que são reproduzidos para a sociedade como meio de informação.

Destaca ainda, o imenso número de softwares com banco de dados errôneos, que caindo em mãos despreparadas, são reproduzidos causando verdadeiros desastres na produção de mapas. Monmonier ilustra isso com a expressão "lixo de dentro é lixo pra fora", ou seja, se o subsídio já é totalmente comprometido, apresentando inúmeros erros, fatalmente, o resultado será na

\footnotetext{
${ }^{17}$ GIRARDI (2003) e GIRARDI (2008) chamam a atenção para esta questão de cientificidade e ao mesmo tempo atrelando este fazer mapas com a ciência geográfica. Explanam sobre a "Cartografia Geográfica", que apresenta o olhar científico sobre o espaço, abarcando todos os requisitos técnicos cartográficos, sem no entanto, dificultar termos de entendimento com usos mais próprios da engenharia cartográfica, e nem mesmo banalizar tal instrumento, como mero fazer artístico.
} 
mesma (des)qualificação, promovendo distorções e desinformações, conforme passamos a comentar a seguir.

\title{
2.2. As distorções e desinformações encontradas em mapas
}

Para tratar das distorções presentes nos mapas, utilizaremos, assim como Monmonier, o termo "mentira", visto que se trata de inverdades sobre o contexto real representado, sendo esta, causadora de desinformação do usuário do mapa.

O mesmo autor ressalta:

\begin{abstract}
Um bom mapa conta uma infinidade de pequenas mentiras sociais, e suprime a verdade para ajudar o usuário a ver o que precisa ser visto. A realidade é tridimensional, rica em detalhes e factual demais para permitir um modelo completo e mesmo organizado em escala gráfica bidimensional. $\mathrm{Na}$ verdade, um mapa que não generalizasse seria inútil. Mas o valor de um mapa depende de quão bem a sua geometria e conteúdo generalizados refletem um aspecto da realidade escolhida. (tradução de Monmonier, 1991)
\end{abstract}

Uma situação bastante comum nos mapas é a maximização e minimização de semelhanças visuais. É claro que a produção cartográfica (mapa) não tem como ser $100 \%$ fiel à paisagem selecionada para representar, assim necessita fazer muita generalização e adequações simbólicas que melhor se aproximem da realidade, sem deturpá-la com a possibilidade de leituras antagônicas. Nesse sentido, alguns produtores não qualificados na área, sentem-se na obrigação de 
utilizar desenhos pictóricos vulgarizados, na crença de que assim estarão facilitando a leitura dos usuários. Mas não é essa a questão, e sim, fazer a filtragem do conteúdo a ser representado, e, escolher as melhores substituições simbólicas de modo limpo e claro, que estará proporcionando este resultado.

Conforme leituras, em nosso referencial, vemos que Monmonier explica que todos os mapas enganam, porque devem ser seletivos nas informações que apresentam: distorcem projeções, ângulos ou formas, por exemplo.

Assim também, mapas em pequena escala, deixam de fora detalhes a serem incluídos nos mapas de grande escala; linhas devem ser deslocadas, alisadas ou simplificadas e que apresentam, portanto, a área simplificada graficamente para facilitar a leitura.

Adverte, e se diverte, ainda o autor, comentando que certos erros em mapas acabam se tornando motivos de piadas e anedotas, quando não tão importantes, mas se constrange ao perceber que os mesmos erros são fatais na situação de uma guerra, por exemplo, omitindo problemas de obstáculos ou impedindo o planejamento de melhores estratégias de ataque e de proteção; isso acaba gerando numa situação de combate, maiores destruições, como maior número de feridos e mortos. Nestes casos, se compreende porque é imprescindível investigar a fonte do mapa base, pois copilar um mapa que já é defeituoso, é praticamente um atentado à própria segurança.

Juntamente com os mapas, Monmonier ressalta os graves problemas com os gráficos, outro documento cartográfico, muito divulgado pela imprensa, formando opiniões erroneamente por se basearem em fontes imprecisas. Tais 
documentos são amplamente utilizados com finalidades manipuladoras. Mas aqui, iremos nos abster apenas a fazer essa menção importante, pois nosso objeto de estudo está focado no mapa.

É indispensável destacar, que a opinião crítica de Monmonier, quanto à imensos erros encontrados nos mapas em época de avanço tecnológico, é a de que, infelizmente, os avanços tecnológicos que tornaram os mapas de notícias menos dispendiosos e mais comuns, também permitiram a má qualificação e a manifestação de artistas analfabetos geograficamente para fazer mapas publicáveis rapidamente $(1991 ; 46)$.

Ele é bastante enfático em dizer que passa a ser irritante a quantidade de erros encontrados em mapas de estradas e de ruas, questionando se é pouco valorizado o trabalho em mapas de alta precisão, pois, diante dos bancos de dados existentes, num mercado que chega a ser competitivo hoje no mundo dos softwares, é inconcebível esse tipo de situação ${ }^{18}$.

Daí a questão que também nos aflige drasticamente, pois se confirma a hipótese de que nada adianta uma disponibilidade maciça de documentos cartográficos de domínio público, se as pessoas que estão elaborando os mapas não possuem conhecimento técnico dos subsídios básicos necessários de serem observados no processo de produção, ou mesmo, compilação de um mapa, e ainda pior, ou seja, mais grave, quando este é instrumento de análise para gerar informações derivadas.

\footnotetext{
${ }^{18}$ Monmonier sugere que um arquivo de reclamações dos clientes pode ser uma fonte útil, embora não totalmente confiável de correções para a próxima edição do respectivo mapa.
} 


\subsubsection{A escala grande na representação dos lugares e a omissão de referenciais de localização}

Compreender como os mapas distorcem a realidade exige uma observação atenta sobre escala, definida na simplicidade como a proporção matemática entre as distâncias do mapa com relação às distâncias reais na superfície terrestre. Mas será que isso é tão simples de se entender e se perceber que este mecanismo pode gerar enganos imperceptíveis aos olhos?

Monmonier (1996), ressalta que mesmo as projeções, que transformam a superfície curva tridimensional do planeta em um plano, bidimensional, em muito pode distorcer a escala do mapa. Explica que, num mapa plano, a escala estende algumas distâncias e abrevia outras, de modo que a escala varia, portanto, de ponto a ponto, e, além disso, a escala, em um ponto, tende a variar com a direção também.

Pode-se dizer que as projeções de mapas distorcem cinco relações geográficas: áreas, ângulos, formas brutas, distâncias e direções, e o cartógrafo muitas vezes precisa adaptar a projeção do mapa para atender a sua necessidade específica.

Também salienta o autor que as escalas gráficas além de mais práticas, são mais seguras que as escalas verbais e nominais, principalmente porque no momento da redução ou ampliação da imagem ela também se transforma, ou ainda, na visão de Monmonier, diríamos que uma escala gráfica continua a ser 
"verdade" quando usamos uma fotocopiadora, para comprimir um mapa maior para um papel tamanho carta, o que não acontece com as escalas verbais ou nominais.

Uma das coisas a não se perder de vista é que nas escalas pequenas a probabilidade de erro e distorção é muito maior que em escala grande, pois, ainda, implica a questão da curvatura da Terra $^{19}$. Sendo assim, os usuários de mapas em grande escala, como planejadores locais e turistas, terão menos problemas quanto às distorções da escala, desde que esta esteja ali representada.

Os mapas de grande escala são altamente personalizados, suas projeções muitas vezes possibilitam retratar medidas relativas, propiciando informações como tempo de viagem e consequentemente custos de transporte, que será bastante pertinente para a finalidade turística, no entanto para isso é primordial a indicação visual de distância ou área de relacionamentos.

${ }^{19}$ É importante saber ainda que:

"O usuário deve ser cauteloso, porém, com a advertência "aproximadamente posicionado" ou o aviso "Este mapa pode não satisfazer os Padrões Nacionais de Precisão Cartográfica." Na maioria dos casos, esses mapas foram compilados a partir de fotografias aéreas não retificadas, nas quais o erro horizontal tende a ser particularmente grande para áreas acidentadas e montanhosas".

(...) Uma exceção é a ortofoto (uma foto tirada em "linha reta"), uma imagem de fotografia aérea eletronicamente alongada para remover o deslocamento de relevo. Um mapa ortofotografado, produzido a partir de ortofotografias, é um mapa de imagem fotográfica planimetricamente precisa. (MONMONIER, 1996; idem). 
No entanto, o problema maior, que geralmente ocorre nos mapas de escala grande, é o excesso de símbolos, podendo ocasionar a poluição visual.

Para resolver problemáticas deste nível, relacionadas a escala, é que necessita realizar uma tarefa bastante importante, no momento em que se pretende produzir um mapa, a generalização geométrica ${ }^{20}$ e de conteúdo ${ }^{21}$, de modo a ser possível representar os dados mais importantes e que sejam

${ }^{20}$ Monmonier explica que no processo de generalização geométrica estão presentes quatro momentos fundamentais: simplificação, deslocamento, suavização e realce, que são necessários não só para refinar o nível de detalhe e evitar interferências gráficas entre limites de domínio e outros símbolos lineares, mas também para reconstruir limites interrompidos por agregação e segmentação.

\begin{abstract}
"A simplificação, que reduz o detalhe e a angularidade, ao eliminar pontos na lista, é particularmente útil se o excesso de pormenores for "capturado" no desenvolvimento de um arquivo de dados cartográficos, ou se os dados desenvolvidos para serem exibidos em uma determinada escala estão sendo exibidos em uma escala menor. O deslocamento evita interferências gráficas ao afastar-se dos recursos que, caso contrário, se sobreporiam ou se confundiriam. Uma redução substancial numa escala, digamos, de 1:25.000 para 1:1.000.000, geralmente resulta em uma coleção incompreensivelmente congestionada de símbolos cartográficos, que apela para a eliminação de alguns recursos e o deslocamento de outros. A suavização, que também diminui os detalhes e a angularidade, pode substituir alguns pontos e adicionar outros à lista. O principal objetivo da suavização é evitar uma série de segmentos de linha reta abruptamente associados. O realce adiciona detalhes para dar uma aparência mais realista aos símbolos cartográficos. As linhas que representam fluxos d'água, por exemplo, poderiam ser dadas por meandros típicos, enquanto os traços de uma praia, lago ou rio poderiam ser feitos de forma a se parecerem mais com uma costa. Símbolos cartográficos realçados são mais facilmente interpretados assim como são mais estéticos" (MONMONIER, 1996, tradução nossa).
\end{abstract}

Enquanto a generalização geométrica procura a clareza gráfica, evitando a sobreposição de símbolos, a generalização de conteúdo promove a clareza da finalidade ou do significado filtrando detalhes irrelevantes para a função ou o tema do mapa. A generalização de conteúdo tem apenas dois elementos essenciais, a seleção e a classificação. A seleção, que serve à generalização geométrica através da supressão de algumas informações, promove a generalização de conteúdo ao escolher apenas recursos relevantes. A classificação, por outro lado, faz o mapa prestativamente informativo, bem como utilizável ao fazer o reconhecimento das semelhanças entre os recursos escolhidos de modo que um único tipo de símbolo possa representar um grupo com características semelhantes (MONMONIER, 1996, tradução nossa). 
pertinentes ao interesse da temática. Monmonier (1991) explica que "a clareza demanda generalização geométrica porque os símbolos cartográficos normalmente ocupam proporcionalmente mais espaço no mapa do que as características que eles representam ocupam no terreno"22. Também ressalta a observação quanto à espessura das linhas, visto que devem se adequar este tipo de implantação simbólica ao tamanho do mapa para não gerar dúbia interpretação.

Portanto, símbolo e mapa devem estar perfeitamente ajustados, para promover uma representação harmônica, favorável a leitura. Lembrando Bertin (1977), que afirma ser esta representação harmônica, um tipo de representação monossêmica, ou seja, que permite a todos os usuários as condições de mesma leitura e decodificação do real ali representado. Tal finalidade é própria dos documentos cartográficos.

Monmonier confirma sua concordância com Bertin, ao afirmar que embora tão misterioso para a maioria das pessoas, como uma língua estrangeira ou matemática, os símbolos projetados em um mapa também beneficia 0 entendimento, atentando para os princípios da lógica e da comunicação.

Apreciar a lógica dos símbolos começa com a compreensão das três categorias geométricas de símbolos de mapa (símbolos de ponto, símbolos de linha ou símbolos de área) e as seis variáveis visuais estudadas por Bertin na Semiologia Gráfica (tamanho, valor, granulação, cor, orientação e forma).

22 (tradução nossa) 
$\mathrm{Na}$ situação de mapas utilizados para fins turísticos, podemos aferir a seguinte observação de Monmonier:

Mapas de estradas e a maioria dos outros mapas de uso gerais usam combinações de todos os três: ponto símbolos para marcar os locais de marcos e aldeias, linha de símbolos para mostrar os tamanhos e formas de rios e estradas, e área de símbolos para representar a forma e o tamanho dos parques estaduais e grandes cidades.

Um dos cuidados com a representação simbólica é que os mapas precisam de símbolos contrastantes, de modo que permita retratar facilmente as diferenças geográficas. Tais símbolos são de diferentes naturezas, porém se adequam a determinadas funções no mapa, dando mais notoriedade, em detrimento de outros, que poderiam até atrapalhar a transmissão da informação.

\begin{abstract}
"Forma, textura e matiz" são eficazes apresentando diferenças qualitativas, como entre terreno, utilizações ou religiões dominantes. Nas diferenças quantitativas, o "tamanho" é mais adequado para mostrar variações na quantidade ou para contar, como o número de telespectadores por área de mercado. Considerando que o "valor de tons de cinza" é preferido para retratar as diferenças de taxa ou intensidade, tais como a proporção... Símbolos variando em "orientação" são úteis principalmente para representar ventos, fluxos de migração, movimentações de tropas e outras ocorrências direcionais. (MONMONIER, 1996. grifo e tradução nossa)
\end{abstract}

A seguir, apresentamos a ilustração de um mapa, onde se destaca uma problemática dessa natureza, ou seja, sobre a leitura e interpretação que se proporciona a partir da escolha da projeção, da escala, bem como, do conjunto de símbolos a serem empregados na representação cartográfica. 
MAPA 16 : Oregon. Percepção de representação em diferentes escalas

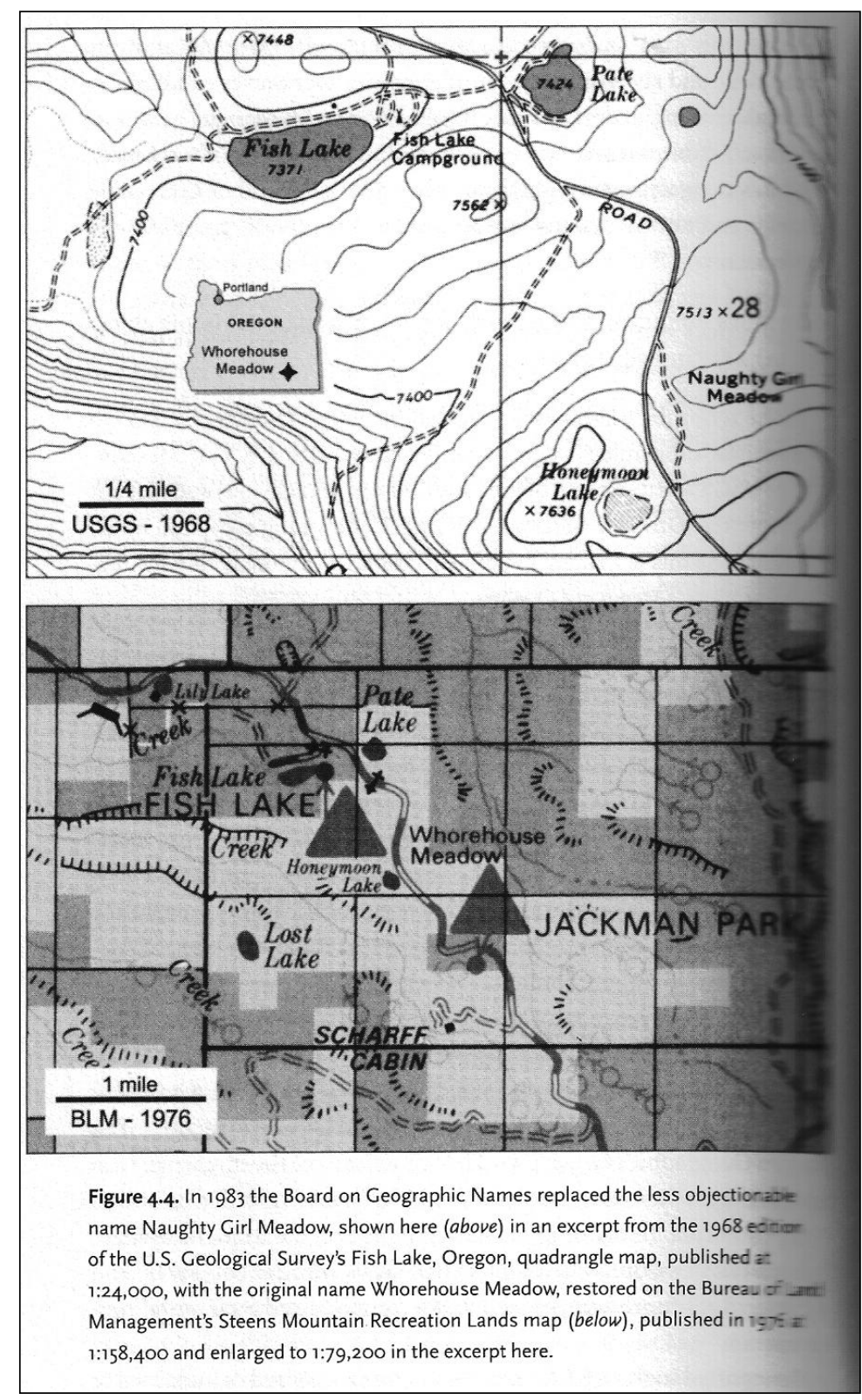

Fonte: MONMONIER, Mark. 2007;66.

Uma das grandes preocupações com a distorção, não se refere à simples projeção e erros de escala, mas principalmente, da interpretação que se faz em mapas que apresentam estes erros. Monmonier (1996) cita como complicador, a 
questão de se compilar mapas para produzir outro sem ter a idéia certa do que é necessário, visto que, os erros se ampliam na medida em que os dados vão sendo transferidos para mapas derivados, já vindos de outro mapa temático, não partindo de um mapa base original.

O autor explica um exemplo aplicado à questão de escala numa representação pontual proporcional de produção de porcos por $\mathrm{Km}^{2}$, supondo que duas áreas possuem a mesma quantidade de porcos, mas por apresentarem uma distorção projectiva, que influencia na escala, acaba por ter seu território diminuído, e com isso os pontos mais concentrados, proporcionando uma falsa impressão de que o aproveitamento espacial proporcional à produção seja maior.

Um dos casos mais exemplares, dessa falsa impressão pela desproporção de escala em razão à projeção cartográfica, é a questão da Groenlândia que em muitos mapas aparece enorme, de dimensões continentais, sendo que é caracterizada como uma ilha.

O caso da Groenlândia, é um exemplo em nível mundial, mas é preciso ter a consciência que em inúmeras situações isso acontece, pois na representação bidimensional a tendência é apresentar, por exemplo, os paralelos na mesma escala do Equador, o que é irreal, uma vez que as distâncias diminuem de acordo com o afastamento desse ponto Equatorial em relação aos pólos. Isso irá interferir fortemente no cálculo de distância em rotas turísticas, por exemplo, se não for pensado este quesito de bastante distorção. Tal situação se insere portanto, também nos mapas temáticos de finalidade turística, que é o nosso objeto de pesquisa. 


\subsubsection{O efeito temporal e a necessidade de atualizações dos dados}

"As informações em um mapa temático são como leite, perecível... logo é essencial verificar a data de produção". (tradução de Monmonier, 1996;54)

Neste quesito, Monmonier nos chama a atenção sobre a inconsistência temporal, ou seja, que o mapeador deve estar cientes de que a realidade não é estática, e que, em seu dinamismo, se alteram as informações mapeadas em tempos anteriores.

Tal temporalidade pode afetar diferenças não só relacionando períodos grandes, pois neste caso, nos referimos mais às mudanças geológicas e geomorfológicas, mas em termos de paisagem natural geral, e, principalmente humanizada (e históricas) ${ }^{23}$, fortemente são as alterações em séculos, décadas, anos, meses e até dias, conforme a temática abordada na representação. Salienta, por exemplo, os temas meteorológicos, que sofrem alterações em questão de horas, e necessitam de um cuidadoso observador para atuar na produção de mapas de previsão. 
Destaca ainda a situação dos mapas censitários, pois muitas vezes são relacionados dados de um período de até meia década, e tal fenômeno pode nesse espaço de tempo, se alterar drasticamente, em função de um acontecimento, ou situação que venha a influenciar, seja no número de habitantes, no seu rendimento, ou qualquer outro dado estatístico visualizado na pesquisa que resultou nestes mapas. Esta situação se torna ainda mais problematizadora quando tais referenciais envolvem questões de âmbito internacional ${ }^{24}$, bem como quando se toma como referencial diferentes fontes de dados, obtidos com diferentes datações.

Daí a importância de todo produto cartográfico ser datado com o maior rigor possível, para não passar uma falsa informação ao leitor usuário do mapa. Da mesma forma, este produtor não deve se basear em recursos (fontes) obsoletos $^{25}$, pois isso agrava muito a situação e, afirma o autor, "ainda que o

"Dados internacionais com base em definições inconsistentes, assim como recenseamentos ou pesquisas assíncronos podem produzir mapas altamente questionáveis. Mapas globais da pobreza, de categorias profissionais e da proporção da população que vive em áreas urbanas são intrinsecamente imprecisos devido às significativas diferenças internacionais nas definições relevantes. Mapas-múndi baseados em dados estatísticos são particularmente suspeitos - ainda que sua validade venha não só de saber os ajustes por parte dos estudiosos ou funcionários das Nações Unidas, mas de categorias amplas, mais gerais que tendem a mascarar diferenças espúrias dentro de grupos de nações mais ou menos desenvolvidas" (Tradução de MONMONIER)

"Os usuários conscientes de mapas modernos leem qualquer bom material impresso que o cartógrafo forneça. Um mapa topográfico em larga escala lançado no ano $\mathrm{N}$ com uma data de publicação do ano $\mathrm{N}$ 2, por exemplo, poderia basear-se em fotos aéreas tiradas no ano $\mathrm{N}-3$ ou $\mathrm{N}-4$, e ter marcado o campo no ano $\mathrm{N}-2$ ou $\mathrm{N}$ - 3. Mas a verificação de campo pode não detectar todas as alterações significativas, e os 
mapa tenha 99,9\% de precisão, o mesmo estará enganando demasiadamente o seu usuário" (MONMONIER, 1996;54).

Neste sentido, nos reportamos ao nosso objeto de pesquisa, os mapas turísticos e, principalmente, ao nosso recorte espacial, onde observamos a repetição do modelo "croqui", que é recopiado ao longo do tempo para elaborar o material que é fornecido aos turistas. Além do descaso para com este detalhe, percebe-se nitidamente informações que já sofreram transformações, ou seja, alguns lugares que nem existem mais e que não foram atualizados nestes mapas.

2.2.3. Símbolos, Cores e Imagens: Atrações e distrações em prol do explorar o imaginário

Alguns meios simbólicos, não fazem parte propriamente de uma convenção cartográfica, no entanto, são utilizados, principalmente em mapas temáticos de uso comum, para facilitar a decodificação, ou seja, a leitura das informações que se deseja representar, sem a necessidade do usuário ficar recorrendo incessantemente à legenda do mapa.

mapas de áreas em constante processo de desenvolvimento urbano rápido são muitas vezes terrivelmente obsoletos. Além disso, mapas derivados que não possuem um bom material impresso podem ser o equivalente a uma cartografia enganadora. Devido aos atrasos de publicação e revisão lenta, mapas derivados "novos" podem muito bem estar dez anos ou mais desatualizados. Ou eles podem estar com apenas quatro anos sem atualização em algumas áreas e dez anos ou mais em outras" (Tradução de MONMONIER, 1996). 
Nesta idéia de facilitar o processo de leitura, também alguns produtores de mapas lançam mão de lendas e rótulos. Aí nos reportamos a Girardi (1997), em seu trabalho sobre a questão dos mitos cartográficos, pois muito mais que representar uma realidade, se reporta à uma ilusão ou à um apelo publicitário. Nesse sentido se entende que uma "lenda" ou "ilusão" pode até tornar um mau mapa útil, mas isso não é o mesmo que torná-lo eficiente.

Monmonier vê esta questão como sendo uma metáfora, muitas vezes enganadora, pois para cada usuário a lenda e o rótulo remeterá à uma "sensação" de leitura diferenciada, corroborando para a deturpação novamente da leitura monossêmica.

Como coerência, percebemos que "Símbolos-padrão, projetados para um reconhecimento imediato inequívoco e dimensionados para uma escala específica, são comuns na cartografia e promovem a eficiência tanto na produção como no uso de mapas" (Monmonier, 1996, tradução nossa).

Podemos perceber diversas formas de como os símbolos trabalham com nossa sensação diante do visual:

Símbolos de ponto pictóricos efetivamente exploram formas familiares, como quando tendas pouco representam campgrounds e pequenos edifícios com cruzes em cima indicam igrejas. Símbolos alfabéticos também utilizar o formulário para promover a decodificação, tal como acontece com abreviaturas comuns, ("PO" para correios ${ }^{26}$ ), nomes de lugares ("Baltimore") e rótulos que descreve o tipo de recurso ("Southern Pacific Railway"). Convenções de cor permitem que símbolos de mapas explorem idealizadas associações de lagos e riachos com áreas

\footnotetext{
${ }^{26}$ Post Office é o termo usado para correio em inglês.
} 
arborizadas e azuis brilhantes... Mapas do tempo tiram proveito das sensações de vermelho como quente e azul como o frio. (tradução de MONMONIER, 1996)

Monmonier também considera uma metáfora tão problemática quanto, na questão da cor, em processo de quantificação representados por mapas coropléticos, pois a cor pode estar invocando um outro grau de quantidade, muitas vezes até condenados à qualidade da impressão gráfica. Neste caso, sugere-se como melhor fidedignidade das magnitudes em dados de contagem ou na representação simbólica de porções de tamanho, como expresso nas variáveis visuais (BERTIN, 1983). Isso se percebe, principalmente, quando o número de classes a se representar é bastante grande e se torna imperceptível na diferenciação de tonalidades dos mapas coropléticos ${ }^{27}$, ou seja, impossibilita a decodificação do leitor do mapa.

Alguns erros de ordem técnica podem frequentemente ocorrer, principalmente, quando se trabalha com tais mapas coropléticos, pois determinadas impressoras podem imbutir um percentual a mais de coloração, transferindo uma percepção errônea sobre a proporcionalidade quantitativa a se representar. Neste sentido exige-se ainda mais atenção do produtor de mapas, que não pode simplesmente programar uma graduação de tonalidades aleatoriamente, sem antes disso, testar seus resultados visuais.

\footnotetext{
${ }^{27}$ Explica Monmonier, que mesmo alterando a escolha de tons de cinza ordenados, para um rol de cores diversas, pouco se melhorará em face de alguns outros fatores preponderantes, como o desconhecimento da ordenação das matizes espectrais, ou ainda a deficiência de diferenciação de cores, denominada de "daltonismo".
} 


\subsection{Mapas para fins de propaganda}

Monmonier ressalta que, para muitos bens e serviços, o mapa é de primordial importância, pois é ele quem direciona o cliente até a sua localidade, não só orientando o tráfego, mas até estimulando a demanda e promovendo a localidade. Explica que se o mapa não conduzir ao melhor caminho, com menos trânsito, e de forma clara, os usuários do mapa poderão considerar dispendioso ir até determinada localidade e dispensarão tal oportunidade. Isso não quer dizer, no entanto ilustrar apenas um único caminho, mas proporcionar, na imagem representativa, as opções de acesso, as distâncias e atrativos do percurso.

Afirma o autor que para a publicidade geralmente se apela para o desejo de impressionar o usuário através do mapa, mas que é muito importante a exatidão e precisão, para surtir o efeito concretizado, de atrair o cliente, sem desagradá-lo com inverdades ou omissões de informação.

A maioria dos usuários mapa voluntariamente toleraram "mentiras brancas" em mapas, e não é difícil para os mapas também dizer mentiras mais graves" . A razão para isto é que os mapas têm um efeito duplo: não só para informar o seu público, mas também para impressioná-los - para convencer, para fazer um ponto, para vender um produto. Pode ser tão simples como a publicidade, sugerindo que sua loja tem uma localização conveniente, ou que a linha ferroviária é mais direta do que realmente é. Mas também pode ser tão sutil quanto a sua escolha de cor ou de sombreamento. (resenha traduzida de Monmonier) 
Tais considerações de Monmonier, atreladas ao nosso arcabouço teórico descrito no primeiro capítulo, serão, portanto, os pilares de nossa análise efetuada sobre nosso recorte sobre o concreto real, que estarão narrados a partir desse momento em que passamos a descrever a pesquisa no campo metodológico prático. 


\section{CAPÍTULO 3.}

\section{O CONCRETO PENSADO TURÍSTICO}

\section{NO UNIVERSO DA PESQUISA \\ GEOCARTOGRÁFICA}

A vida é a arte de tirar conclusões suficientes de dados insuficientes.

(Luis Fernando Veríssimo)

3.1. Os Procedimentos Metodológicos de Investigação

Toda pesquisa científica, em especial em nível de tese, necessita de uma validação concisa de seu conteúdo como um todo. Tal validação acontece em dois níveis: o lógico (ou teórico) e o prático (com relação à realidade).

Aqui dispomos nos dois primeiros capítulos o nosso conhecimento lógico, baseado em vários autores nacionais e internacionais, mas principalmente na teoria americana de Monmonier, que propiciou refletir sobre as inverdades (mentiras) e incoerências (erros) que aparecem nos mapas. 
Quanto ao nosso desenvolver prático, retrataremos neste terceiro capítulo, toda a nossa investigação de campo, os métodos empregados, os resultados obtidos e a nossa análise diante dos mesmos.

A parte que aqui chamamos de lógica, diante de nossa fundamentação na metodologia científica de CERVI (2009), contribui na formação e delimitação dos conceitos defendidos. Tais conceitos científicos são produtos de leituras e de um diálogo reflexivo constante com nosso referencial.

Como se sabe, metodologia e os procedimentos metodológicos dizem respeito ao processo científico pelo qual se transitará os dados empíricos, a experiência prática, atrelados aos encaminhamentos científicos conceituais, para se alcançar o produto final da pesquisa, a teoria propriamente dita, ou seja, a nossa tese.

Segundo Cervi 2009, "Em sentido amplo, ciência significa conhecimento, enquanto em um sentido estrito, ela visa explicar fenômenos com evidências possíveis". Sabendo-se que existem várias formas de conhecimento, entende-se - que distingue esse conhecimento tido como do "censo comum", do conhecimento "científico" é o método de explicação.

Cervi explica: "Método, do grego, significa "caminho para...". O método científico possui uma lógica própria para validar seus resultados. "Ele é basicamente empírico-dedutivo, chegando a conclusões a partir da análise do mundo real".

A lógica que percorremos é a de verificar em campo qual a produção cartográfica realizada no Município de Ponta Grossa com destinação de atender 
ao turista, como ela se apresenta, ou seja, que tipo de atributos cartográficos (e simbologias) são utilizados, como essa produção chega ao visitante, e como este mesmo visitante avalia tal produto (mapa turístico), quanto à eficácia na satisfação de seus interesses nesse tipo de material.

\subsubsection{A pesquisa de campo prévia e as coletas de dados diversos}

Num primeiro momento, nosso interesse estava centrado em fazer um comparativo dos mapas em diferentes localidades do Estado do Paraná. Assim, elegemos cinco localidades de maior potencial turístico (Foz do Iguaçu, Maringá, Ponta Grossa, Curitiba e Paranaguá ${ }^{28}$ ), fizemos contato solicitando material e fomos a campo para observarmos algumas coisas que nos seriam importantes.

Algumas de nossas observações efetivadas nas cinco regiões contribuirão para a nossa análise da tese, em função de ocorrências que foram sendo observadas ao longo da pesquisa, com a aquisição dos materiais, porém, em função do tempo restrito, acatamos a sugestão da banca de qualificação, para centrarmos nossa análise apenas em Ponta Grossa, pois seria muito difícil realizar uma pesquisa de campo mais apurada diante de localidades tão esparsas.

\footnotetext{
${ }^{28}$ Descartamos nessa condição, Londrina, por se tratar de um turismo mais centrado à atrativos comerciais.
} 
Mapa 17: Mapa Turístico de Maringá

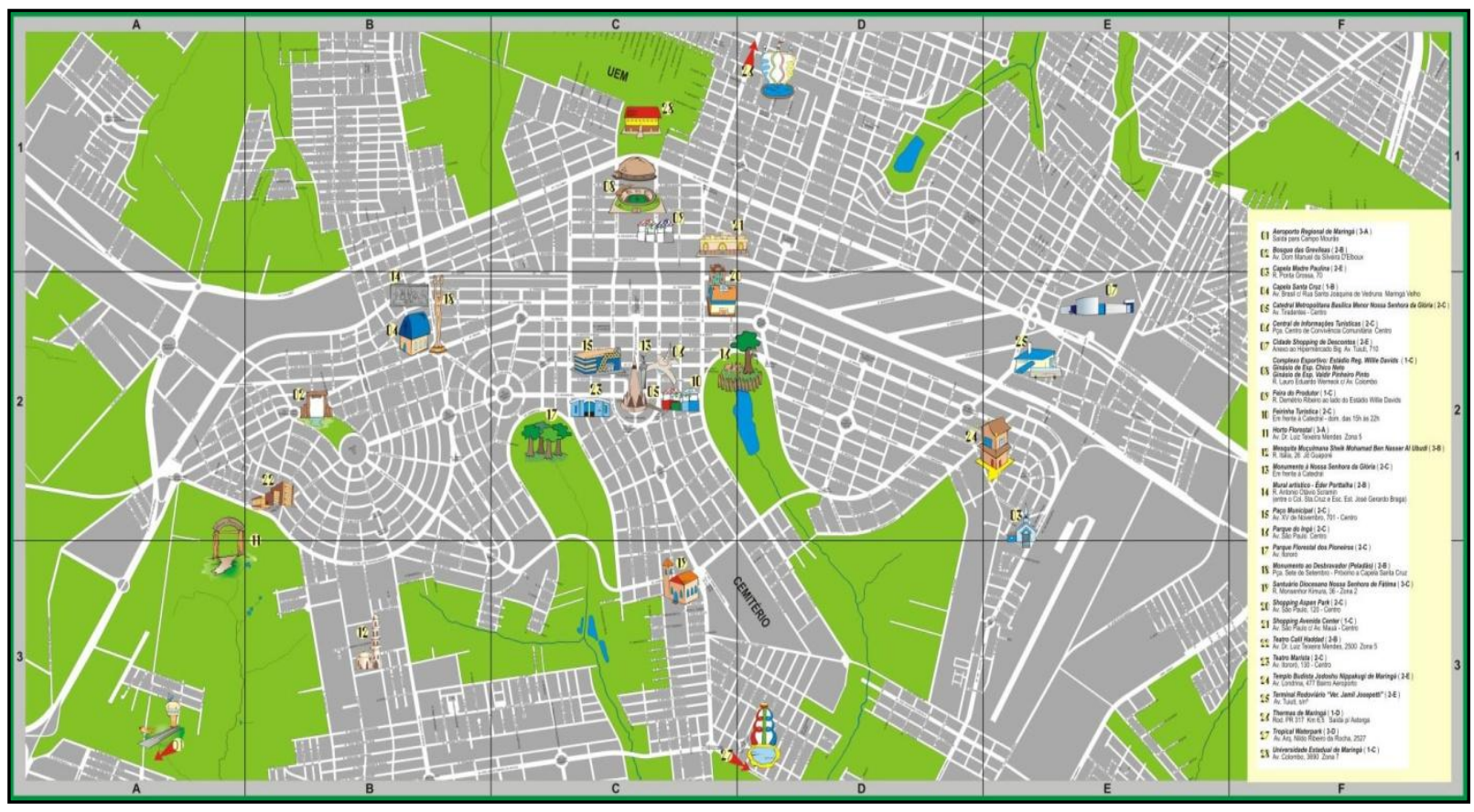

Fonte: Secretaria de Turismo de Maringá

Este é apenas um dos mapas utilizados em Maringá para a finalidade turística. Durante uma primeira visitação, a secretaria de turismo nos explicou que muitas vezes os mapas são produzidos de acordo com as finalidades do turismo, se é comercial, de lazer, tendo até mesmo um roteiro "kids ${ }^{29 "}$, destinado a atender o interesse de visitações de crianças e jovens.

Consultando o mapa do Município de Maringá, disponível na internet, encontramos a manifestação de usuários que criticavam sobre a forma de representação gráfica e até mesmo a ausência de localidades de grande interesse, como os terminais de ônibus urbano e rodoviário.

\footnotetext{
${ }^{29}$ Lê-se infantil.
} 
Tal crítica também foi mencionada por alguns visitantes de Foz do Iguaçu, num momento em que coletávamos os mesmos materiais e fazíamos um préteste com os turistas. Os mesmos enfatizaram o descaso com a representação da rodoviária, sendo que a mesma com certeza é de grande interesse dos visitantes que por ali passam.

Algo que nos chamou bastante a atenção foi a respeito da leitura de alguns funcionários que atendiam à visitações sobre alguns mapas turísticos "mentirosos" (Mapa 18), visto que um deles apresentava toda a passarela de visitação das Cataratas do Iguaçu, dentro do curso do rio.

A explanação nos fez refletir sobre as descredibilidade que os usuários passam a ter mediante aos mapas, visto que tais ocorrências são tão perceptíveis, mesmo por pessoas leigas na profissionalização de mapeadores.

Alguns também apontam para a controvérsia problematizadora, tanto a escassez de informação, como a poluição, que compromete a leitura. Afirmam que a necessidade do mapa está vinculada ao interesse em se chegar aos pontos turísticos e, muitas vezes, isso se torna impossível pelos erros de representação, chegando a encontrar materiais que apontam diferentes referenciais de localização, deixando-os em dúvida sobre qual seguir.

O caráter poluidor está mais vinculado à produção artística excessiva, que apela pelo esforço de divulgação do caráter prazeroso dos lugares, o que não deixa de ser envolvente para alguns, mas que deveriam apresentar em contrapartida, ainda que em separado, um documento cartográfico mais claro e prático, de modo a tornar o turista um visitante independente de guias e agências. 
Mapa 18: Mapa Turístico de Foz do Iguaçu

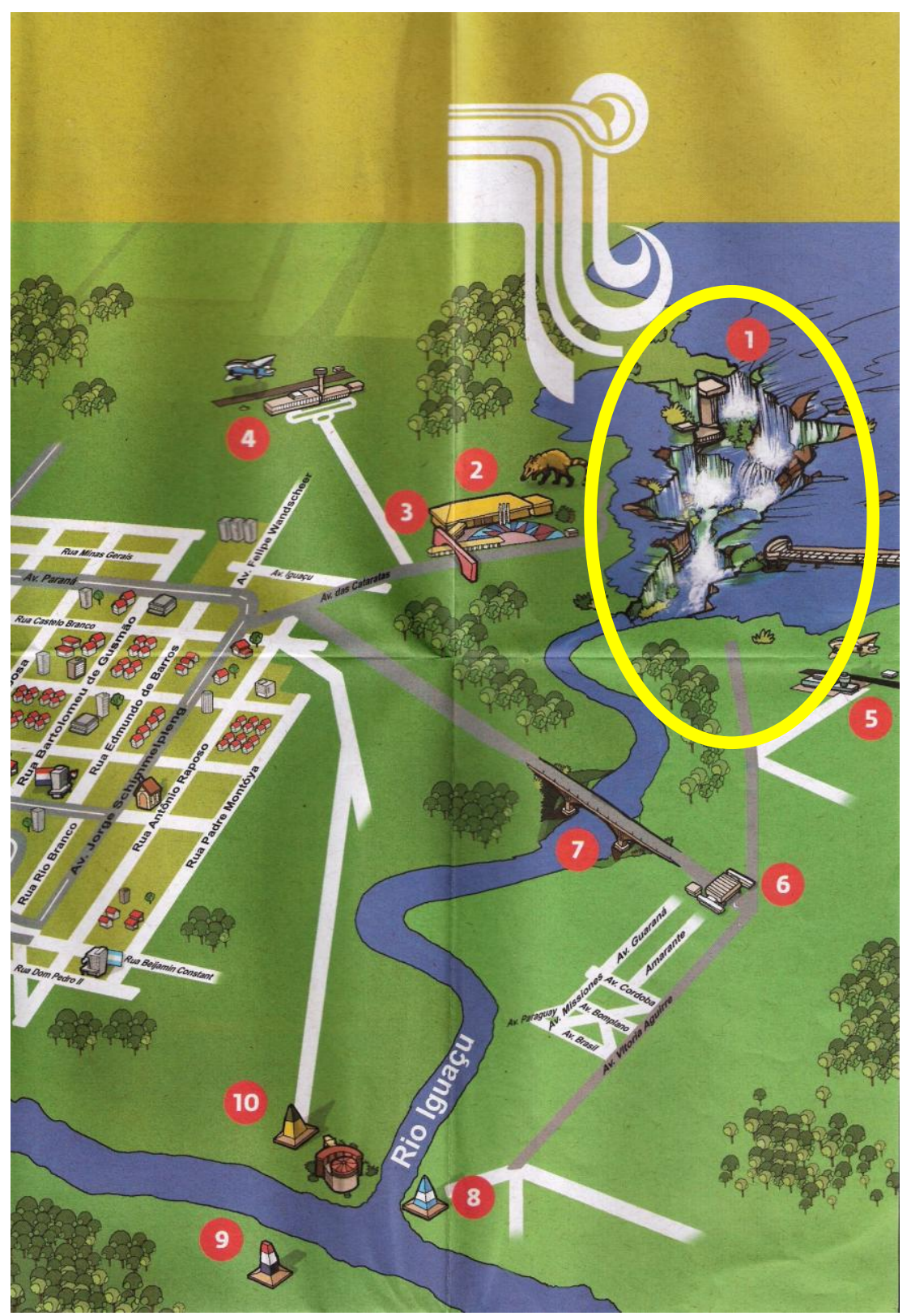

Fonte: Secretaria Municipal de Turismo de Foz do Iguaçu (destaque nosso)

Outra região elencada previamente para nossa pesquisa foi a capital do Estado, Curitiba. Nesta cidade encontramos uma infinidade de mapas destinados ao turismo. Percebe-se no município uma cultura cartográfica muito mais avançada, visto que as localidades são todas sinalizadas com enfoque para os 
pontos turísticos, os serviços atrelados ao serviço do turismo, como hotéis, restaurantes e atrativos de visitações possuem material informativo com mapas de localizações de interesse, e ainda, em algumas praças e ponto de ônibus, temse um mapa fixado, para oferecer à população, condições de orientação espacial onde quer que se encontrem.

Diante dessa realidade, não nos preocupamos tanto com o atendimento às necessidades do turista com relação ao produto cartográfico, visto que, por fornecerem tantas condições de acesso à informação, acreditamos que nessa situação, alguns materiais podem se dar ao "luxo" de ousar na criatividade artística representativa, pois não trará prejuízos ao turista, uma vez que ele tem uma infinidade de meios de localização e de investigação específica sobre cada atrativo.

Na capital, ninguém vai a um evento sem receber neste, um mapa, que é o convite para visitação e, ao mesmo tempo, uma demonstração da organização que é passada ao visitante no intuito de atendê-lo, fazendo-o ficar por mais tempo.

Entre os diversos mapas encontramos até mesmo os subtemáticos, voltados para esse setor: Mapa de hotéis e restaurantes, Mapa da rota turística, Mapa de parques, entre tantos existentes.

Na sequência, apresentamos um dos mapas obtidos, sendo que é muito fácil encontrar os respectivos materiais espalhados pela cidade e distribuídos a população. 
Mapa Turístico de Curitiba

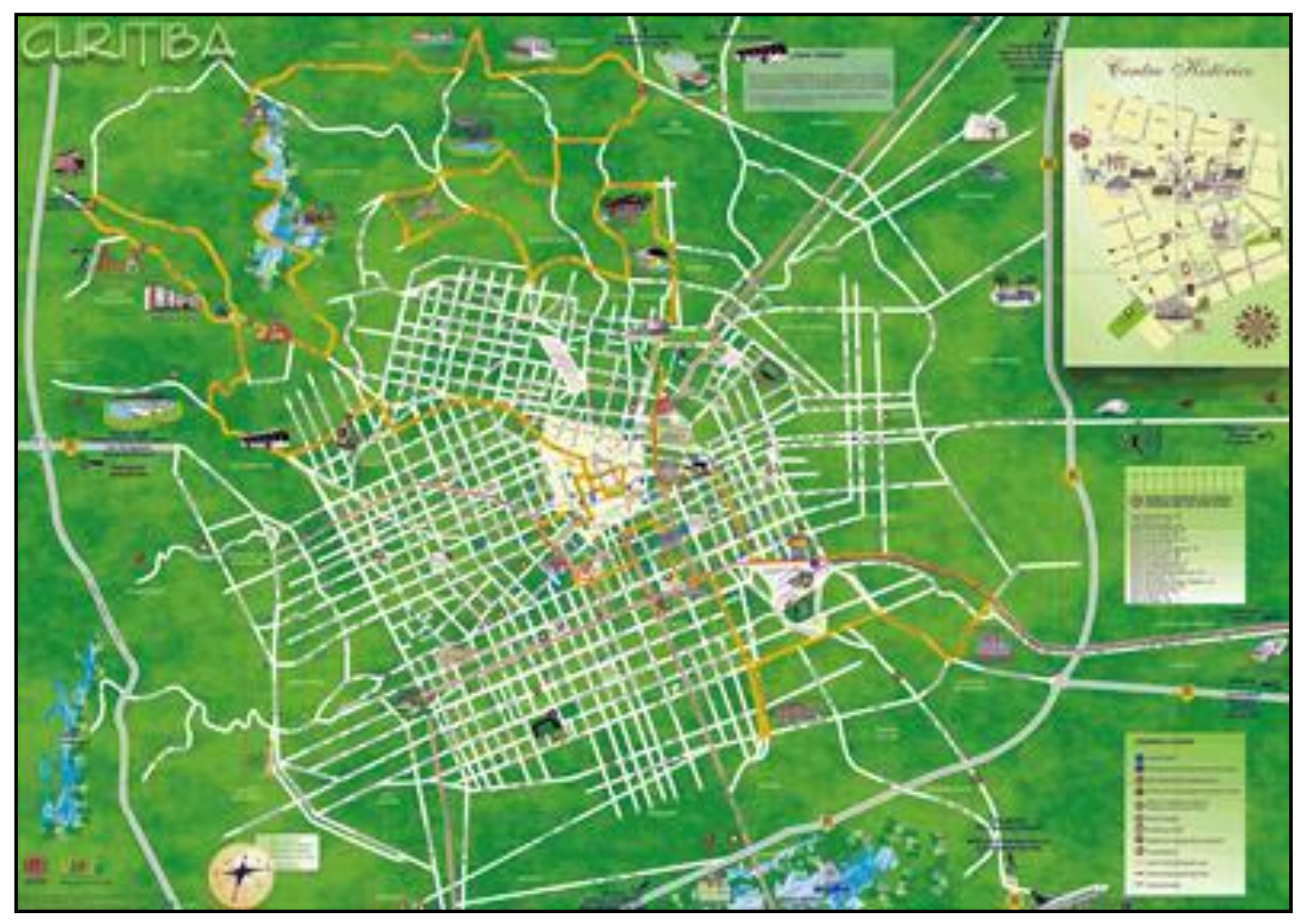

Fonte: Secretaria de Turismo de Curitiba

Com relação à parte litorânea, que geralmente é um dos lugares de maior visitação voltada ao turismo de lazer, de férias e de sol e mar, nos defrontamos com a dificuldade de delimitação sobre que localidade eleger como a principal desse complexo, e poder assim, checar os materiais cartográficos, mapas turísticos.

$\mathrm{Na}$ sequência, ilustramos algumas das localidades desse complexo, com mapas mais antigos, sendo que, o que obtivemos por meio de contato com a Secretaria de Turismo de Paranaguá, além de outros que nos foram disponibilizados sobre toda a regionalização litorânea, incluindo llha do Mel e Superagui, que também são de grande interesse turístico. Salientamos que os respectivos mapas antigos, apesar da precariedade em produção gráfica, se apresentam bastante limpos para facilitar a leitura. E que, para isso, identificam 
apenas nomes de ruas e enumeram os pontos de visitação para que sejam consultados a identificação de cada qual através da legenda.

\section{Mapa 20: Mapa de Paranaguá}

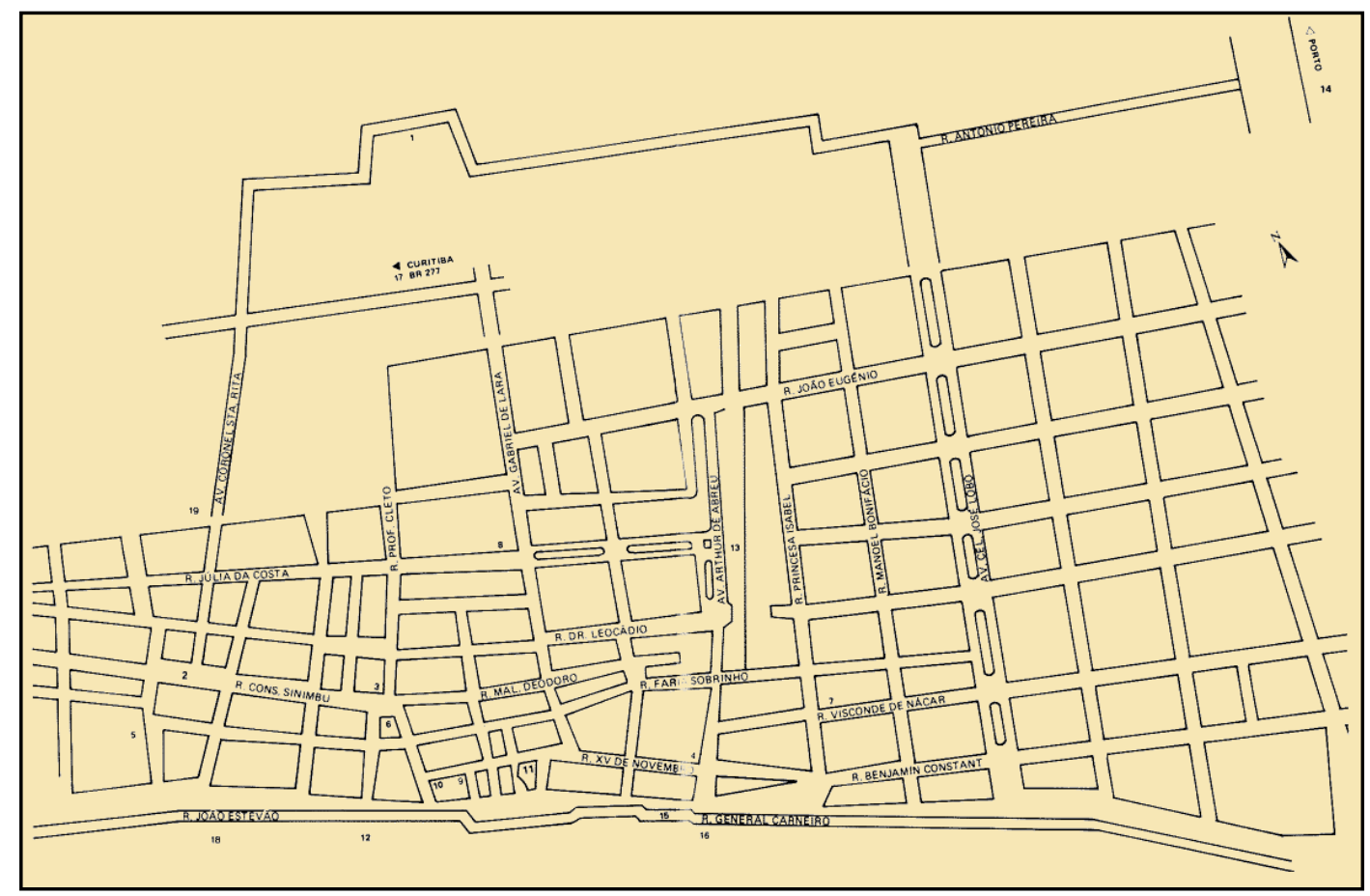

\section{Legenda:}

1. Igreja de Nossa Senhora do Rocio

2. Igreja de São Benedito

3. Igreja de Nossa Senhora do Rosário

4. Teatro da Ordem

5. Fonte Velha

6. Casa Monsenhor Celso

7. Palácio Visconde de Nacar (Câmara Municipal)

8. Palácio São José (Prefeitura Municipal)

9. Museu de Arqueologia e Etnologia de

Paranaguá

10. Museu do Instituto Histórico e

Geográfico de Paranaguá
11. Mercado Municipal do Café

12. Mercado Municipal Brasílio Abud

13. Estação Ferroviária

14. Porto D. Pedro II

15. Rua da Praia

16. Rio Itiberê

17. Terminal Municipal Rodoviário

18. Cachoeira da Quintilha

19. Parque Aquático Alexandra 
Um quinto Município elencado previamente para a pesquisa foi então Ponta Grossa, que acabou sendo posteriormente o único em nosso recorte espacial, de modo a favorecer uma pesquisa mais aprofundada com a possibilidade de aplicação de entrevistas com uma amostragem diversificada, permitindo fazer uma análise documental e também de campo, para vislumbrar em diferentes ângulos de visão, como é o mapa turístico de Ponta Grossa e qual a avaliação do mesmo, quanto à sua qualidade, eficácia e servidão aos usuários deste instrumento de informação.

$\mathrm{Na}$ coleta de material, um primeiro mapa que observamos e que nos chamou a atenção sobre o caráter pictórico é este apresentado logo em seguida. No entanto não o utilizamos para aplicação de uma análise, embora façamos posteriormente alguns comentários que se reportarão a este, em específico.

\section{MAPA 21. Mapa Turístico de Ponta Grossa}

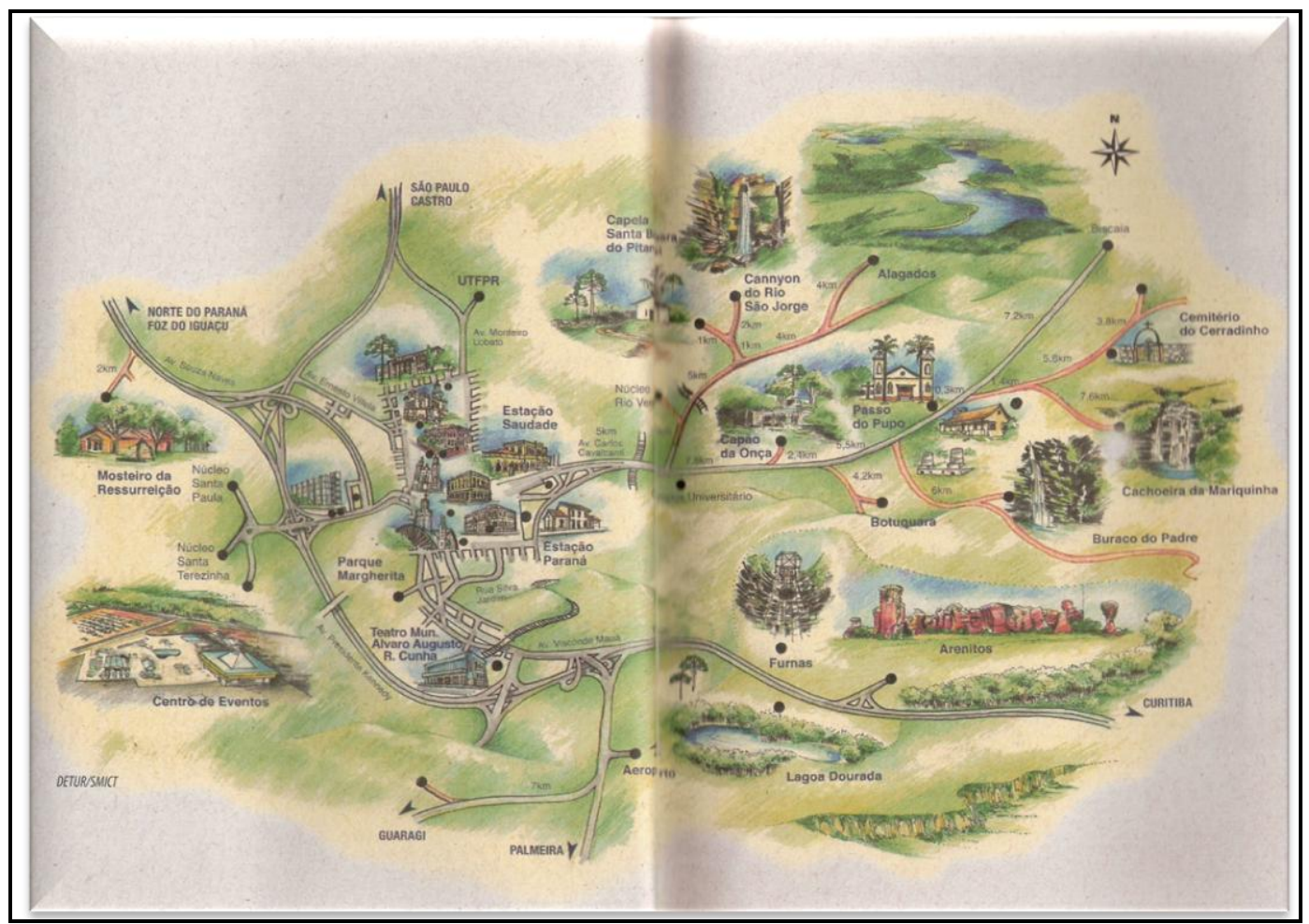

Fonte: Secretaria Municipal de Indústria, Comércio e Turismo de Ponta Grossa 
Determinado o nosso recorte espacial como sendo o Município de Ponta Grossa, passamos a delinear o material de investigação de campo, e o método de tabulação e análise de tais respostas.

\subsubsection{O Método Quantitativo e a Estatística Descritiva}

Novamente nos remetemos a Cervi (2009), por ter encontrado neste, o suporte, a alternativa para nós mais viável de aplicação de um método de pesquisa que não permitisse obscuridade e, ao mesmo tempo, favorecesse uma leitura ampla e reflexiva. O mesmo autor reforça nossa convicção sobre a escolha deste método afirmando que:

o quantitativismo tem seu lugar na ciência por se tratar de um conjunto de técnicas de pesquisa social e análise que, ao ser bem aplicado, permite relacionar descobertas sobre padrões de comportamento social com implicações nas teorias sociais já existentes.(CERVI, 2009; 12)

Desse modo, ao contrário do que muitos pensam, o método quantitativo não é um simples contar e medir características, de modo positivista (como abordado por Comte $^{30}$ ), mas nos permite antes de tudo fazer classificações de

${ }^{30}$ In: REALE, Giovanni \& ANTISERI, Dario. Historia da Filosofia - VOLUMES I, II, e III. Antiguidade e Idade Média, do Humanismo a Kant, do Romanismo até nossos dias. São Paulo: Paulus, 1990. 
tendências e variáveis, e, a partir destas, estabelecer uma análise mais precisa sobre o objeto de estudo, seja ele um fenômeno natural ou social.

É claro que, previamente, já se hipotetiza algumas possibilidades, pois como afirma Cervi (2009) "só se quantifica, o que se sabe que existe" pois é impossível classificar, e principalmente quantificar, quando se tem a noção de distinção entre diferentes variáveis que possibilitam este tipo de análise e, ainda assim, geralmente temos uma leitura compartilhada entre o quantitativo e o qualitativo, caso este, que utilizamos em nossa realização prática, através de perguntas estruturadas objetivamente, e outras abertas, para se efetivar a análise do discurso qualitativo.

Evitamos o embate polêmico entre método quantitativista e qualitativista. Para nós, é oportuno termos a melhor visão possível sobre o objeto e, nesse sentido, medimos quando for possível, e analisamos, de forma subjetiva, quando é necessário. Para nós não há produtividade numa escolha metodológica específica e única. Essa composição de quantificação mais qualificação é que nos permite estabelecer o olhar crítico e ao mesmo tempo conciso que pretendemos sobre a problemática investigada, dando-nos suporte de estabelecer relações de impactos entre ciência e realidade.

Em nossa análise empírica da realidade partimos da quantificação de dados primários e secundários sobre a realidade, consultando documentos e aplicando questionários diretamente aos sujeitos, turistas e para entender ainda mais algumas questões fizemos análise de discurso com algumas perguntas subjetivas aos turistas e também com entrevista gravada aplicada à alguns responsáveis do setor, no Município de Ponta Grossa. 
A consciência de que cada pesquisa seleciona seus próprios padrões de organização do cotidiano social pesquisado na realidade em concreto, em especial numa situação de tese, permite-nos afirmar que não buscamos aqui nos espelhar em nenhum outro modelo utilizado em pesquisas anteriores, criando o nosso próprio direcionamento, de acordo com as nossas necessidades de investigação.

\subsubsection{Estrutura de questionário: perguntas abertas e fechadas}

O modelo de questionário utilizado, com perguntas abertas e fechadas, ou seja, com quantificação e abordagens qualitativas, favorece como mencionamos anteriormente uma análise mais ampla, no sentido em que Lefebvre ${ }^{31}$ descreve como sendo parte de uma lógica formal (ou concreta da forma, abstraída de uma visão única) e uma lógica dialética (na interação e contradição de elementos opostos, até mesmo entre sujeito e objeto).

$\mathrm{Na}$ aplicação da investigação em campo tivemos a obtenção de ideias, conceitos, evidências que serviram para a análise das representações cartográficas por parte dos usuários dos mapas turísticos que estavam visitando pontos turísticos da cidade de Ponta Grossa.

${ }^{31}$ In: REALE, Giovanni \& ANTISERI, Dario. Historia da Filosofia - VOLUMES I, II, e III. Antiguidade e Idade Média, do Humanismo a Kant, do Romanismo até nossos dias. São Paulo: Paulus, 1990. 
Durante a entrevista, foi possível observar que, as pessoas, muitas vezes, identificam a necessidade de informações e até mesmo requisitos essenciais de uma representação cartográfica, embora confundam em conceito as mesmas, fazendo uso dos termos "mapa", "carta", "folder", "planta", praticamente com o mesmo significado.

Tais ideias e conceitos vêm de encontro com as premissas de nossa teoria, onde o importante não é a definição de um e outro instrumento em si, como afirma Harley (1989), mas sim os resultados de transmissões gerenciadas num material cartográfico de forma eficaz, pois é claro que, sujeitos leigos na área científica, não terão a mesma linguagem de pesquisadores.

O que se buscou, portanto, com a pesquisa empírica estruturada em questionário foram as evidências de problemas nos materiais cartográficos destinado aos respectivos turistas. Diante da infinidade de informações captadas atrelamos a técnica de correlação dos dados. Muitas das características quantificadas fizeram parte de nossas hipóteses prévias, uma vez que analisando mapas de outras localidades conseguíamos observar "discrepâncias de ordem científica e informacional".

O passo seguinte, após aplicação dos questionários, com ajuda de estagiários, foi o tratamento das evidências em trabalho de gabinete, ou seja, a tabulação primeiramente em tabelas e gráficos, que são por sua vez relacionados à tais técnicas quantitativas.

Após esta realização, foi feita uma nova consulta do material, selecionando informações apenas das questões abertas (subjetivas). Nestas questões foram 
escolhidas as abordagens pessoais que mais se repetiam, ou que eram bastante pertinentes ao problema tratado.

Tais ferramentas, quantitativas (estatísticas) e qualitativas (questões abertas do questionário e entrevistas específicas), serviram de suporte a toda análise efetuada na integração entre os dados obtidos empiricamente e todo o embasamento teórico. Ressaltando que, além da população alvo representada pelos visitantes dos pontos turísticos, também foram entrevistados o produtor de um dos mapas, e a chefe de departamento de turismo, completando assim as informações necessárias para compreender este "concreto pensado"32".

\subsubsection{Definições estatísticas, distribuição de frequências e tipos de variáveis}

De modo bastante sucinto, estabelecemos esta subdivisão textual para explicar aqui como distribuímos nossos atributos de observação para se tabular na estatística, de modo a conseguir obter tanto a frequência como as variáveis.

Escolhemos aleatoriamente, 450 (quatrocentos e cinquenta) sujeitos, em idades, formações e profissões diferenciadas, que estiveram presentes em diferentes pontos turísticos da cidade de Ponta Grossa. Todos foram agrupados

\footnotetext{
${ }^{32}$ Expressão muito utilizada por Milton Santos (2006), para se referir à realidade pesquisada.
} 
visto que desejávamos observar o todo, numa diversidade ampla ${ }^{33}$. Por este motivo é que o número de entrevistados exigiu um contingente elevado, para ter uma margem de erro menor.

Após perguntas básicas sobre o perfil de cada um e como os mesmos concebem as necessidades de um mapa ou outro documento cartográfico de modo a ser útil para as visitações turísticas, e como este tem utilizado estes materiais (ou se não utiliza, questionando o porquê). Na segunda parte da entrevista aplicada com instrumento de questionário com pergunta estruturada, fora perguntada sobre os dois últimos mapas elaborados para servir aos turistas neste mesmo município. Para isso, foram definidos 15 atributos a serem avaliados a respeito destes mapas, e apresentando cinco variáveis de escolha valorativa para cada quesito, e cada um dos materiais.

A tabulação destes resultados de análise de ambos os mapas feitas pelos turistas foram por sua vez apresentadas de modo sobreposto, para se observar as comparações e divergências avaliadas entre um e outro.

$\mathrm{Na}$ sequência passamos a descrever detalhadamente, todo o resultado deste trabalho de investigação (tanto com relação às fontes primárias quanto secundária), estabelecendo o diálogo com nossa teoria apresentada nos dois primeiros capítulos, numa concretização da análise objetivada para esta tese.

\footnotetext{
${ }^{33}$ Cervi (2010), explica via informação verbal, que não importa o número de habitantes do local para definir a quantitade de pessoas a serem entrevistadas, mas sim ter em mente o grau de heterogeneidade que pretendemos: "Se quiser fazer testes estatísticos inferenciais, ou seja, que sejam representativos de toda população, você precisará de cerca de 450 questionários respondidos. Isso te dará uma margem de erro de 5 pontos percentuais e intervalo de confiança de 95\%". Explica ele, que isso demanda pegar pessoas diferentes, com características de gênero, idade, grau escolar, profissão diferente, caso contrário, obteremos uma padronização representativa de um único grupo, uma única parcela $\mathrm{X}$ da sociedade, e não uma visão do todo.
} 


\subsection{Os Resultados da Pesquisa}

Como já relatamos, para efetuarmos a pesquisa, realizamos uma divisão em etapas: uma com entrevistas abertas e gravadas com chefe de departamento, responsável por ponto de informações turísticas e produtor do mapa atual; outra etapa com entrevistas escritas, com perguntas semiestruturadas mais na objetividade, com a possibilidade de inserir observações.

Esta etapa de entrevista escrita foi a mais importante, pois investigou os visitantes dos pontos turísticos (residentes e externos ao município), numa amostragem de 450 (quatrocentos e cinquenta) sujeitos, presentes em algum dos locais concebidos como potencialidade turística no Município de Ponta Grossa. Foram, portanto, utilizados como pontos de coleta: Parque Estadual de Vila Velha, Buraco do Padre, Capão da Onça, Rio Verde, Cachoeira do Rio São Jorge, Cachoeira da Mariquinha, Estação Saudade e Museu Campos Gerais. Por ser uma entrevista que demandava mais de quinze minutos, e sendo a amostra populacional bastante numerosa, necessitamos de auxílio de estagiários na aplicação dos questionários.

Como o principal local de visitação em Ponta Grossa trata-se de uma RPPN, o Parque Estadual de Vila Velha, tombado como Patrimônio Histórico do Paraná, tivemos que solicitar a autorização da pesquisa, junto ao Instituto Ambiental do Paraná (IAP) localizado em Curitiba, com encaminhamento do projeto, ficando na espera por mais de um mês, para que tramitasse na instituição e obtivéssemos o deferimento do pedido (anexo). 
Os dados secundários da pesquisa foram obtidos de informações coletadas no parque mês a mês em 2009 (anexo), e permitiu-nos traçar um perfil dos visitantes, sendo que, a aplicação dos questionários, ocorreu nos três primeiros meses de 2010, visto que como observamos neste relatório anual, era maior a frequência de visitação, e necessitávamos de muitos sujeitos para entrevistar, demandando assim, menor número de dias, pois para atender as normas do Parque, precisávamos obedecer aos horários de visitação, que são programados, e ficava difícil abordar um montante grande de turistas, visto que tomava bastante tempo, para preenchimento, com análise individual do material.

A maior parte destes questionários, foi aplicada no Parque Estadual de Vila Velha, não só por ser o principal ponto de visitação de Ponta Grossa, mas também por estar entre os principais Parques do Estado do Paraná, conforme podemos observar em gráfico na sequência :

Quadro 2 - Visitantes dos principais atrativos do Paraná - Anos/visitantes

\begin{tabular}{|l|l|l|l|l|l|l|l|l|l|}
\hline Locais & 1995 & 1996 & 1997 & 1998 & 1999 & 2000 & 2001 & 2002 & 2003 \\
\hline Iguaçu $^{\#}$ & 884.335 & 830.255 & 734.280 & 726.667 & 772.287 & 767.157 & 735.775 & 645.832 & 764.709 \\
\hline $\begin{array}{l}\text { Vila Velha } \\
\text { Campinhos }\end{array}$ & 192.931 & 154.251 & 153.251 & 125.801 & 138.650 & 131.133 & 114.334 & $* * *$ & ${ }^{* * *}$ \\
\hline $\begin{array}{l}\text { Arthur } \\
\text { Thomas }\end{array}$ & 113.322 & 111.899 & 129.246 & 145.755 & 144.335 & 159.550 & 98.508 & 98.215 & 86.943 \\
\hline $\begin{array}{l}\text { Monge } \\
\text { (taipu }\end{array}$ & 60.475 & 58.588 & 41.290 & 32.793 & 36.837 & 38.734 & 55.710 & 95.877 & 66.665 \\
\hline
\end{tabular}

(\# atrativos nacionais e estaduais; * atrativos municipais) 
O respectivo quadro nos chamou muito a atenção, pois percebemos que 0 montante de visitação em Vila Velha caiu muito no ano de 2009, comparando com anos anteriores, fazendo-nos refletir se isso é em decorrência do preço, ou se a burocracia de visitação, instaurada após processo de revitalização, tem espantado os turista. Mas isso seria um problema para outro viés de pesquisa, e, portanto, não nos deteremos a explanar a respeito.

\section{Perfil dos Visitantes no Parque Estadual de Vila Velha}

O Parque Estadual de Vila Velha foi escolhido para a coleta do perfil de visitantes pelos seguintes motivos:

- É o ponto turístico mais visitado no Município;

- Apresenta toda uma estrutura turística adequada e administrada por órgãos públicos competentes, permitindo o acesso de qualquer tipo de visitação;

- No próprio local existe um sistema de cadastro de informações dos visitantes, auxiliando-nos neste processo de coleta de dados;

Num estudo prévio, através de fontes secundárias, ou seja, relatórios institucionais (anexo) buscamos vislumbrar o perfil dos frequentadores do Parque, e para isso, nos focamos dentro dos seguintes aspectos: 


\section{\#Total de frequentadores e Gênero}

Em 2009, o número total de visitações foi de 40.430 sujeitos, numa distribuição bastante equilibrada entre homens (19.505) e mulheres (20.925). O mês mais frequentado foi dezembro com 5.527 visitantes e o menos frequentado foi setembro com 1.848 .

\section{\# Meio de Condução}

Nesta avaliação, as alternativas de respostas, para que os visitantes respondam o tipo de condução que utilizaram para chegar ao parque são: carro, moto, van, ônibus de excursão, ônibus escolar, ônibus de linha (circular do município), bicicleta, a pé e outros. O que mais se sobressai na realidade pesquisada é a utilização de carro (29.068), veículo próprio, para se dirigir à localidade. Seguidos dos ônibus de excursão (6.393) e os ônibus escolares (2.774), e ainda as vans (999) e motos (735). O ônibus de linha ${ }^{34}$ é bem pouco usado para a sua capacidade de veiculação (210). De bicicleta, a pé e outros, correspondem a uma amostragem bastante pequena, de 6 (seis) pessoas em cada quesito.

Para ilustrar este atributo, elaboramos um gráfico que é apresentado na sequência. Este gráfico permite perceber que a maioria dos visitantes realmente

\footnotetext{
${ }^{34}$ Destaca-se que este ônibus de Linha tem dois locais de Saída. A rodoviária, onde se tem o ponto de informações turísticas, e o terminal de ônibus do bairro de Oficinas, que se localiza na saída para Curitiba, e portanto mais direcionado para o destino a seguir. O mesmo sai de hora em hora, e o custo é o mesmo de uma passagem normal para qualquer circulação urbana interna no município.
} 
utiliza, na maioria das vezes, veículo próprio. Isso implica na necessidade de deslocamentos independentes para executar as visitações, logo, demandam de informações das localidades, ou seja, necessitam de um mapa informativo para esta temática, o turismo.

\section{Gráfico 1: Forma de condução}

\section{Forma de Condução}

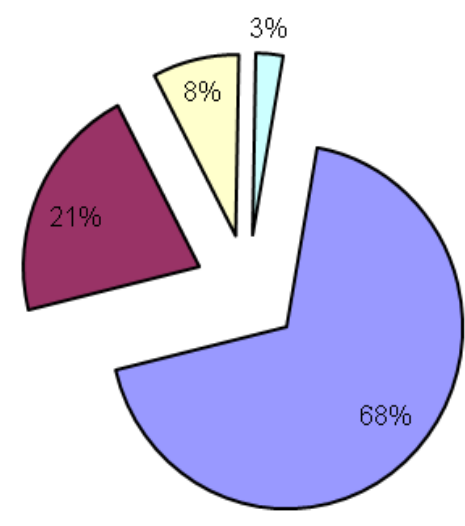

$\square$ Veículo próprio

口Ônibus coletivo local

口Van ou ônibus de

Turismo

口Transporte escolar

Fonte: organização de ULLER, A. S., 2010.

Esta constatação aponta para a necessidade de maiores esclarecimentos das vias de acesso aos lugares, ou seja, um bom referencial de orientação, bem como de escala, para poder ter a percepção das distâncias entre um ponto turístico e outro. É claro que a legenda não fica de fora desta preocupação, visto que é através da mesma, que dar-se-á o entendimento de identificação entre as informações. 
Isso nos faz lembrar, da grande produção dos mapas de estrada de rodagem, que muitas vezes foram distribuídos gratuitamente, com o intuito de promover as viagens terrestres, fazendo com que os veículos consumissem combustível, na época de grande exploração dos poços petrolíferos (meados do século $X X)^{35}$.

\section{\# Faixa Etária}

A idade dos frequentadores e turistas do Parque é bastante diversificada, porém se percebe um maior percentual da população adulta, na faixa entre os 21 e 50 anos (21.487), o que demonstra um maior interesse e, também disposição, para enfrentar as caminhadas que requerem o percurso de visitações. Mas não deixam de ter a frequência de idosos, acima dos 50 anos (4.875), de crianças de 0 a 12 anos (6.097), e adolescentes (7.673), sendo que estas duas últimas categorias de frequentadores são muito caracterizadas por estudantes e por crianças que vem na companhia de seus pais.

Percebe-se também que a frequência dos adultos, fora da faixa de idade de estudo, é bem maior nos meses de férias de verão e inverno (dezembro, janeiro e julho), já dos adolescentes e adultos, em período de estudo, mais no decorrer de meses de atividades escolares, o que demonstra que para os trabalhadores, é mais fácil realizar estas atividades em férias, enquanto os estudantes, muitas vezes, vêm com grupos de estudo, em excursões feitas pela própria instituição, como atividade extracurricular.

\footnotetext{
${ }^{35}$ Estudos enfatizados por AKERMAN, 2002.
} 


\section{Frequência de práticas turísticas}
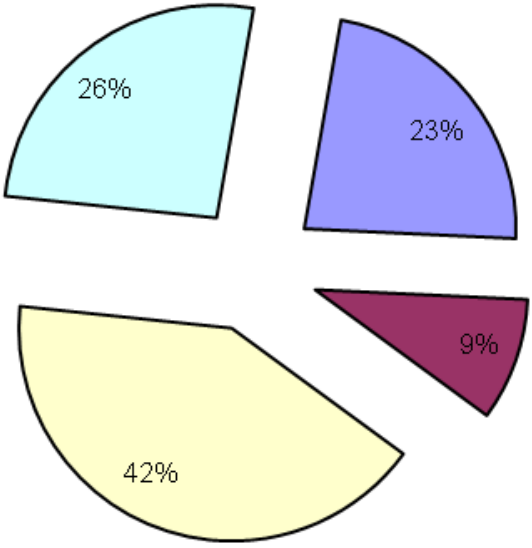

$\square$ quase não viaja

$\square$ viaja só para fins de estudo

口viaja ou visita lugares só em férias

$\square_{\text {viaja e visita lugares com }}$ frequência

Fonte: organização de ULLER, A. S., 2010.

No gráfico, visualizamos então, o predomínio de visitações durante férias, seguido de certo equilíbrio entre os que visitam lugares turísticos com frequência, e quem quase não viaja, ou executa atividade do gênero.

\section{\# Origem dos visitantes}

Com relação à origem dos frequentadores do Parque, observamos que um grande montante é da própria localidade, é claro, mas como moradora do Município, reconhecemos que, mesmo assim, o índice local ainda é muito 
pequeno, demonstrando certo descaso e desvalorização pelos habitantes locais, o que é muito triste, pela relevância turística que o Parque Estadual de Vila Velha, em particular, apresenta em nível nacional e até internacional.

O fluxo de visitantes é maior, logicamente, com relação a pessoas oriundas de cidades do próprio Estado do Paraná, sendo que a capital, Curitiba, se destaca como a cidade que mais visita. Cabe aqui destacar que a população de Curitiba parece ter o espírito de valorização bastante aguçado com relação aos parques e patrimônios, dá-se a observar a própria dinâmica de visitação nesse tipo de lugar, na capital. No entanto, além de moradores locais e de Curitiba, listamos ainda visitantes dos seguintes Municípios que se fizeram presentes: Cascavel, Londrina, Paranaguá, Campo Largo, Maringá, Toledo, Irati, Araucária, Francisco Beltrão, Foz do Iguaçu e outras em menores indicadores.

Com relação a outros estados, constatamos a forte presença dos paulistas (SP), catarinenses (SC), e gaúchos (RS). Mas ainda visitaram pessoas do Rio de Janeiro, Mato Grosso, Mato Grosso do Sul, Rio Grande do Norte, Distrito Federal, Ceará, Goiás, Espírito Santo, Minas Gerais, Amazonas, Pará, Alagoas, Pernambuco e outros.

Muitas pessoas de outros países também fazem parte do especial rol de turistas que frequentam o Parque. Estes, muitas vezes, fazem parte de excursões, ou pacotes turísticos particulares, que colocam no roteiro, Ponta Grossa, devido ao Parque Estadual de Vila Velha. Vale ressaltar que este ponto se faz tão importante para o setor do turismo, não só em nível local, mas regional e até nacional, que no período de dois anos em que o Parque esteve fechado para procedimentos de revitalização pelo IAP, muito do serviço caiu, havendo 
desistência de turistas quanto a pacotes nacionais e internacionais, que geralmente se destina a Curitiba como local estratégico, por não estarem ofertando neste período, a possibilidade de visitação à Vila Velha ${ }^{36}$.

Dentre os países que se fazem presente, enquanto frequentadores do Parque, através de seus turistas estrangeiros, encontramos nos dados de registro: em primeiro lugar a Alemanha, seguida da França e Estados Unidos. É bastante forte também a presença de visitantes da Holanda, Paraguai, Itália e Inglaterra. Mas ainda destacamos pessoas da Bélgica, Canadá, Portugal, México, Japão e outros. Dentre estes outros, aqui não aparece a representatividade em 2009 de países africanos, mas já tivemos visitantes de Moçambique no ano anterior, bem como em 2010, em nossa entrevista encontramos um grupo de Angola, Cabo Verde e Guiné.

Tais dados coletados, nos permitiram um perfil geral dos visitantes que circulam pelos pontos turísticos de Ponta Grossa, e, juntamente, com as entrevistas que executamos com a Diretora da Secretaria de Turismo e com o responsável pela produção de um dos mapas (material 2, anexo), e nossa base teórica, subsidiaram elencar os tópicos do questionário escrito, aplicado aos visitantes, pois permitiu-nos confrontar a necessidade dos turistas, e a visão de profissionais que atuam frente ao setor, de modo direto, ou indireto.

A seguir transcrevemos partes importantes dessas entrevistas, fazendo novas menções posteriormente, em momentos oportunos.

\footnotetext{
${ }^{36}$ Temática de discussão no Conselho Municipal de Turismo do Município de Ponta Grossa, no qual fizemos parte como suplente, durante um curto período de tempo, na substituição de uma professora representante do departamento de Geografia da Universidade Estadual de Ponta Grossa. Na ocasião se refletia muito sobre o imenso déficit econômico relacionado ao setor, em função da paralisação do Parque Estadual de Vila Velha, e que muitas operadoras de turismo ligavam para perguntar, quando o mesmo seria reativado, devido à desistência de pacotes turísticos, direcionados à Capital, Curitiba, com visita à Vila Velha, em Ponta Grossa.
} 


\section{\# Entrevistas e Correlações com outros Dados Coletados}

Em nosso diálogo, a Diretora Municipal de Turismo destaca que, além de todo o potencial turístico natural, de repercussão estadual, nacional e até internacional, Ponta Grossa é muito movida por negócios e eventos ${ }^{37}$, identificados como: congressos, seminários, exposições, feiras, festivais culturais, etc. Nessas oportunidades os hotéis ficam lotados ${ }^{38}$, e os períodos de intervalos nestes eventos são sempre destinados a visitações de nossos atrativos turísticos.

Partindo do pressuposto de que Ponta Grossa tem a sua função Turística mais direcionada para negócios e eventos ${ }^{39}$, nos questionamos se a mesma atende a demanda, frente aos equipamentos turísticos que possui: hotéis, restaurantes, centro de convenções, estacionamentos. Percebe-se que existe

\footnotetext{
${ }^{37}$ Situação que não depende da cidade ter qualquer outro atrativo do âmbito natural, mas sim uma forte importância no contexto econômico e de formação intelectual.

O turismo de negócios tem suas particularidades em relação às outras tipologias do turismo. Ele não depende de atrativos naturais ou artificiais para seu desenvolvimento e sobrevivência. Ao contrário das outras destinações turísticas, a cidade onde o turismo de negócios é significativo, necessita focar seus esforços investimentos, planejamento e gestão na cadeia de serviços para receber o turista, impressioná-lo, convidá-lo a estender sua estada e até motivá-lo a voltar com frequência. (PEREIRA; BORGES, 2006,p. 62).
}

${ }^{38}$ Utilizando Rodrigues (1997), poderíamos entender essa situação diante da subdivisão das espécies de turismo com relação ao território, como a prática de um "turismo sem território" num "território turístico", vista a enorme potencialidade paisagística natural do município. Um instigante paradoxo a se refletir politicamente para criar melhores estratégias de aproveitamento que favoreçam a localidade.

${ }^{39}$ Ramo do turismo que engloba tanto as viagens individuais por motivos profissionais, como os deslocamentos de grupos maiores, e até organizados, para encontros científicos, reuniões empresariais, associações de classe. 
uma carência relativa, pelo tamanho da cidade, que com seus mais de 300.000 (trezentos mil) habitantes, conta com apenas 13 (treze) hotéis ${ }^{40}$.

Neste sentido, percebemos a necessidade de um planejamento mais arrojado para este fim, por ter sido os negócios e eventos, o principal chamariz de pessoas para o Município. São inúmeros os eventos ao longo do ano, sendo os mais fortes relacionados à Agropecuária, Odontologia, Direito, Administração entre outras, ou seja, muito vinculados à função econômica e universitária do Município (Figura 9).

FIGURA 17: Tipos de eventos realizados em Ponta Grossa
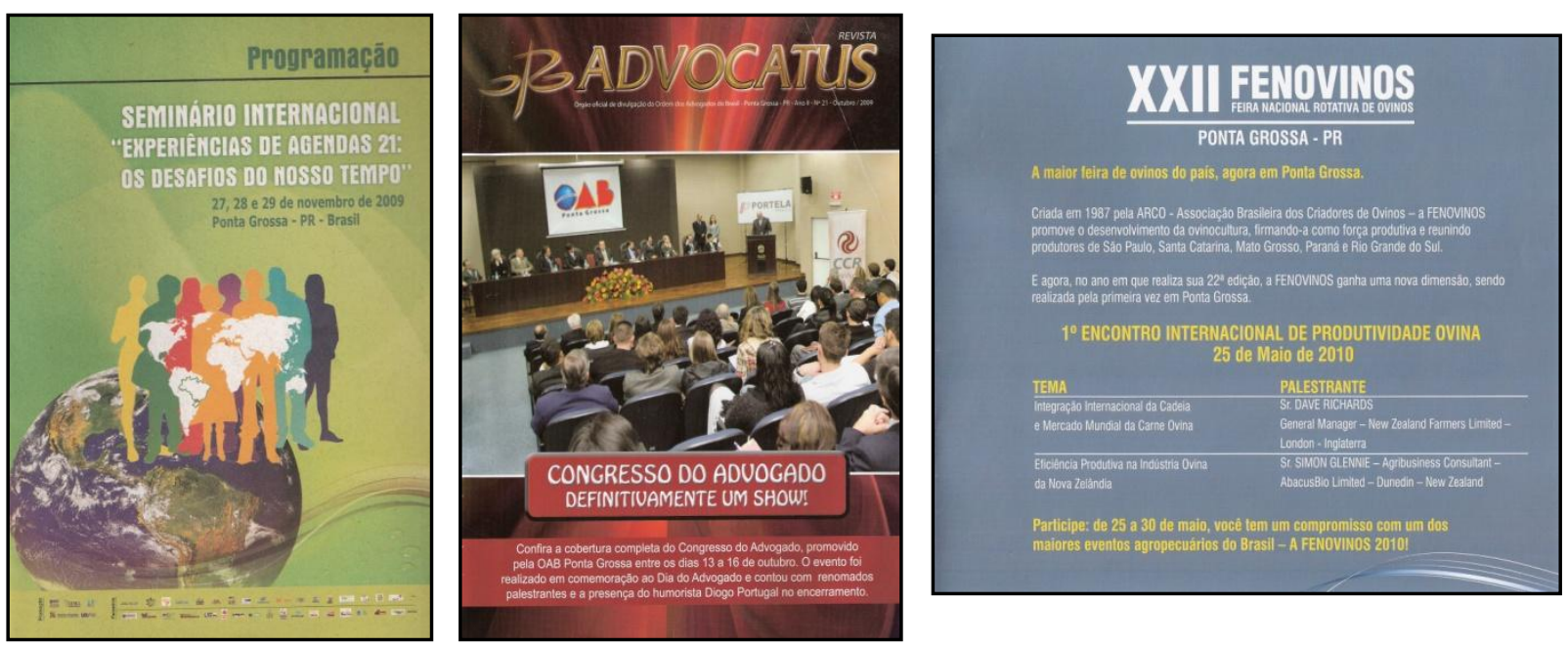

Fonte: Secretaria Municipal de Indústria, Comércio e Turismo de Ponta Grossa

A mesma diretora, explica a grande dificuldade de estender políticas públicas mais arrojadas, para os locais de atrativos naturais, pois a maioria destes potenciais turísticos fica em propriedades particulares, e estes proprietários, não

${ }^{40}$ Bristol Vila Velha Hotel, Hotel Barbur Plaza, Geneviee Palace Hotel, Hotel Papai Cogo, Hotel Pax Express, Planalto Palace Hotel, Hotel Princess Express, Hotel Santa Fé, Hotel São Marcos, Hotel Schafranski, Slaviero Executive Ponta Grossa \& Philadelphia Convention Center, Ponta Grossa Plaza Hotel e Hotel Princesa. 
se agregam ao interesse público, de expandir o setor, ao contrário do que vem acontecendo com os pontos de turismo rural, onde os proprietários tem se reunido e solicitado apoio à secretaria, que através de políticas públicas destinadas ao serviço, estão ofertando aos mesmos, cursos preparatórios para se adequarem ao setor, e ainda, elaborando um mapa temático especial, que enfoca tais atrativos reconhecidos como pousadas, hotéis fazenda, vinícolas, criadouros, e outras funções vinculadas ao campo.

Entre os lugares de interesse de visitação turística no Município, destacamse, entretanto, a rara beleza dos potenciais naturais, que vem em primeiro plano, nas opções de visitação, como pode ser observado na pesquisa, e da ilustração do gráfico que vem sendo apresentado na sequência.

Os patrimônios históricos e culturais também despertam interesse, mas de uma parcela bem menor da sociedade, talvez pelo desconhecimento dos visitantes em função de que são pouco divulgados. Assim, destinados aos locais histórico-culturais, a visitação tem sido mais centrada ao interesse da população local mesmo.

De qualquer forma, listamos um rol dos lugares de visitação no Município, para verificar essa preferência, pois isso vem de encontro às nossas expectativas de investigação, sobre o mapa, de modo a verificar, se os mesmos supriam a necessidade de localização de tais pontos turísticos, para os seus usuários.

Gráfico 3: Lugares de Interesse de Visitação Turística em Ponta Grossa 


\section{Lugares de interesse em visitação turística em Ponta Grossa}

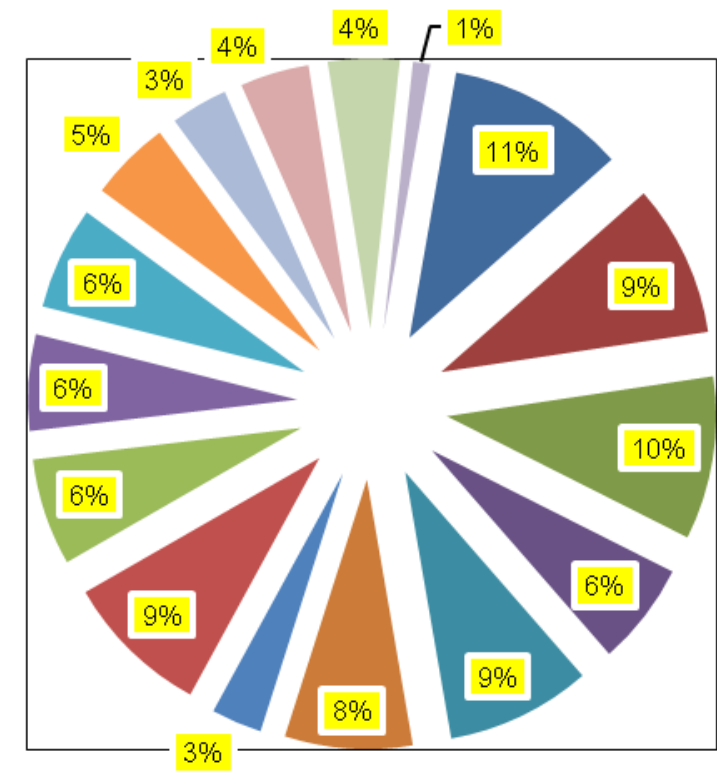

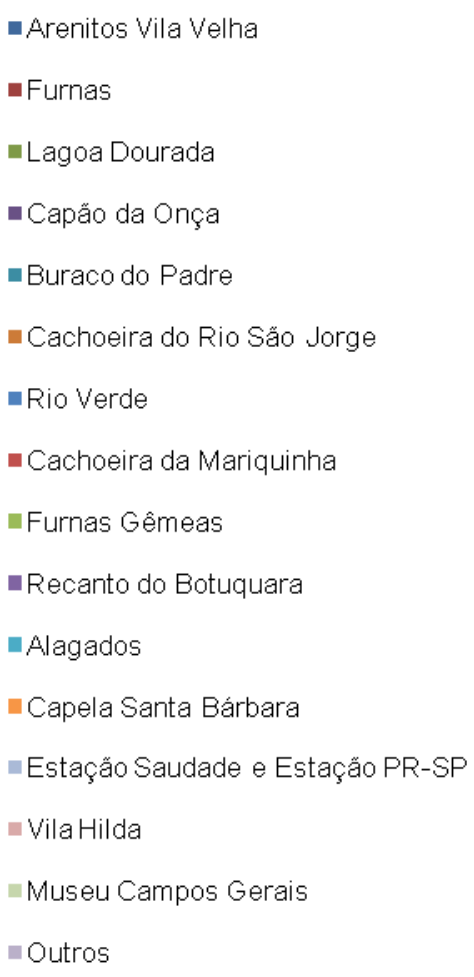

Fonte: organização de ULLER, A. S., 2010.

Observa-se através desse gráfico, a nítida preferência dos visitantes com relação aos lugares naturais, sendo que, Vila Velha se sobressai fortemente, por ser fácil de reconhecimento da localização, embora muitos turistas tenham citado que hoje preferem visitar outros pontos, onde o percurso é menos dirigido, pois sentem que o monitoramento excessivo em Vila Velha, acaba colocando os 
anseios de visitação do turista muito engessado em horários e tempos de percurso.

Também verificamos o grande interesse das pessoas em visitar a Capela Santa Bárbara, primeiro tempo religioso da Cidade, tombado pelo Patrimônio Histórico Municipal. No entanto, muitos afirmam não saber chegar até lá, mesmo sendo morador do Município.

Aproveitando a oportunidade de entrevista gravada, conversamos um pouco com a atendente do posto de Informações Turísticas, que se localiza na Rodoviária e que, no momento, estava sendo organizado, ou seja, administrado, por uma professora de história da rede estadual de ensino. A mesma, que é autora de vários livros sobre a cidade, relatou sua insatisfação com as condições de atendimento que a secretaria dispõe para o turista.

Uma das situações das quais os visitantes mais se defrontam, é a falta de informação quanto à forma de acesso. Neste sentido, o posto de informações tinha apenas um material a ser distribuído (material 1 da pesquisa, anexo) e em muitos casos, afirma a entrevistada, os esclarecimentos eram feitos buscando outras estratégias.

Abaixo, apresentamos um gráfico, obtido das respostas dos visitantes pesquisados, que confirmam a fala da professora que nos atendeu, demonstrando enorme desconhecimento das potencialidades turísticas locais, ora por falta de divulgação, ora por ignorância quanto à suas localizações, sendo muito pouco difundido recursos cartográficos, bem como emplacamentos na cidade, para essa finalidade, de proporcionar melhor orientação espacial. 


\section{Conhecimento das potencialidades turísticas de Ponta Grossa}

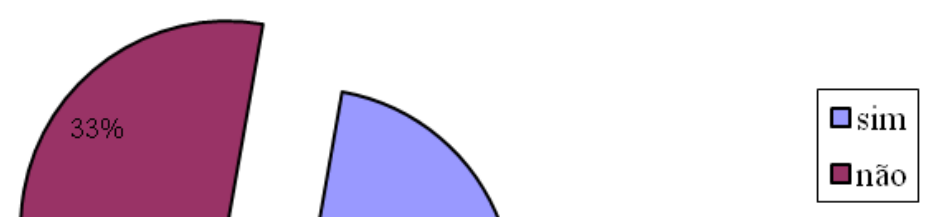

Fonte: organização de ULLER, A. S., 2010.

A professora narra que muita gente procura o posto de atendimento ao turista para obter informações, e ela fica preocupada se estas pessoas conseguirão chegar aos seus locais de interesse, e com que imagem sairão, a respeito do município, diante da política de atendimento ao visitante.

Questionando os visitantes, percebemos que as pessoas gostam muito de conhecer novos lugares, e levar seus familiares e conhecidos que vêm até a cidade, para conhecer as belezas da região. No entanto, muitos, até residentes na própria cidade, desconhecem a localidade da maioria dos pontos turísticos. Neste caso, os empecilhos para visitação (seguidos da falta de tempo), acaba sendo a desinformação quanto à localidade, conforme pode ser visualizado a seguir, e respaldando as preocupações da professora atendente em seus depoimentos durante a entrevista. 


\section{Motivos que impedem de visitar todos os pontos turísticos}
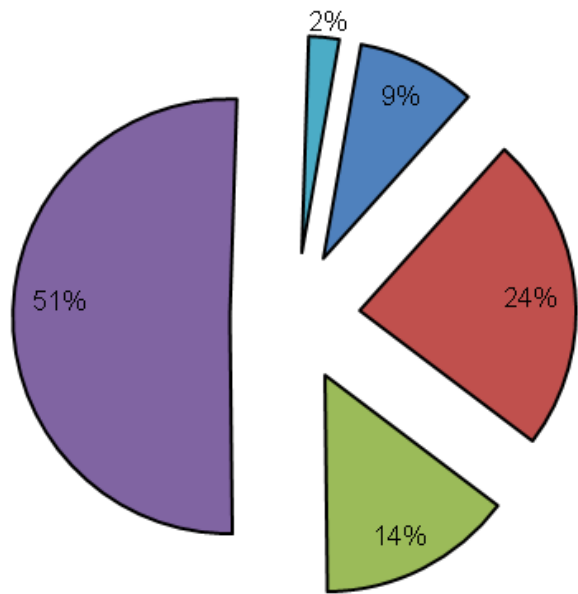

$\square$ falta de condições financeiras

$\square_{\text {não sabe onde se }}$ localizam

$\square$ dificuldade de acesso

$\square$ falta de tempo

口Não respondeu

Tanto a professora, quanto os próprios visitantes entrevistados, destaca a falta de passeios programados para os lugares (não existe este tipo de atividade no município, nem por parte de agências de turismo).

Alguns mencionam ainda sobre a falta de diversidade para alojamento, ou seja, outras opções na estrutura de acomodação turística, pois muitos visitantes solicitam por albergues, que tem um custo bem mais inferior.

Enfim, diante de nosso interesse maior, voltamos a centrarmos naquilo que aparece de forma bastante enfática, a falta de atualização dos materiais cartográficos e principalmente a distribuição de um material adequado acessível a todos em diferentes localidades de acesso. 
Partimos então para uma nova entrevista, agora com o Turismólogo Marcos, que possui uma empresa denominada ORBIPLAN, que trabalha com consultorias de planejamentos de áreas turísticas, entre outras, e que foi 0 responsável pela elaboração do matéria 2 (anexo), que utilizamos para análise nesta tese, por ser o mapa mais atualizado do Município e destinado para a finalidade turística.

Uma primeira questão que nos chamou a atenção, é como um Turismólogo, elaborou um material tão coerente à Cartografia Temática, em detrimento aos muitos materiais que já havíamos observado em todo país. Ao responder nossa questão, foi possível compreender. O mesmo é mestre em Geografia, e se especializou em geoprocessamento, área vinculada à Cartografia Informatizada.

Nesse sentido, muito mais que uma função de designer, que faz de softwares de mapeamento, ele realmente domina os requisitos básicos e essenciais à representação gráfica, o que justifica a apresentação destes em seu material.

Questionamos então sobre a dificuldade de encontrar este mapa hoje, em qualquer localidade, pois conseguimos algumas amostras na Secretaria de Turismo, e nem foi suficiente para distribuir aos estagiários, e anexar na tese. E ainda, em toda localidade que íamos aplicar os questionários, as pessoas nos perguntavam como fazer para conseguir este material, pois era bastante eficaz e, os mesmos, não conheciam. 
O entrevistado então relata que foi contratado para elaborar um mapa para esta finalidade do turismo. Porém a tiragem era bastante limitada, cerca de 5.000 (cinco mil) exemplares, sendo uma parte deles distribuídos nas escolas (1 para cada estabelecimento), porque faziam parte de um projeto educacional, da Secretaria do Turismo de Ponta Grossa, financiada pelo Ministério do Turismo. Outra parte dos exemplares, destinado à demais instituições públicas, sobrando poucos exemplares, até porque, tal mapa estava disponibilizado no site da Prefeitura. Este mapa, explica o entrevistado, fazia parte de um Kit, com cartilha e Cd-rom, e não sei o motivo do porque ter sido feito só essa tiragem.

"Hoje há uma nova proposta de se fazer um mapa mais pictórico (de mais fácil entendimento), mas no momento estamos trabalhando num mapa turístico especial para Ponta Grossa, só para a finalidade de turismo rural", relata o mapeador. Isso nos deixou por um lado contente, pois verificamos que a Cartografia Temática para fins Turístico continuará nas mãos de um profissional capacitado, por outro lado, ficamos perplexa com a informação de que a Secretaria solicitou um mapa mais pictórico, afirmando que a demanda é de um mapa "mais fácil".

Não cremos que apresentar um rigor aos critérios cartográficos essenciais torne o mapa de difícil acesso à comunidade, ao contrário, nossa pesquisa demonstrou, que mesmo os leigos, que não dominam a linguagem cartográfica, dão preferência à um material fidedigno, que permita informações completas e exatas para atender às suas necessidades.

Com tais informações, é possível compreender que determinados enfrentamentos não estão atrelados simplesmente ao campo científico e 
demanda de qualificação profissional, pois está centrado no desinteresse por parte de políticas públicas, como identidade geoturística do próprio Município, conforme fazemos um breve comentário a respeito neste momento.

Continuando na apresentação de nossa pesquisa prática, passamos a tratar desse perfil geoturístico do Município de Ponta Grossa, voltando a comentar detalhes das entrevistas, nas situações em que estivermos abordando análise de material.

\subsubsection{O Município e seu perfil geoturístico}

\section{Mapa 17 : Localização de Ponta Grossa no Estado do Paraná}

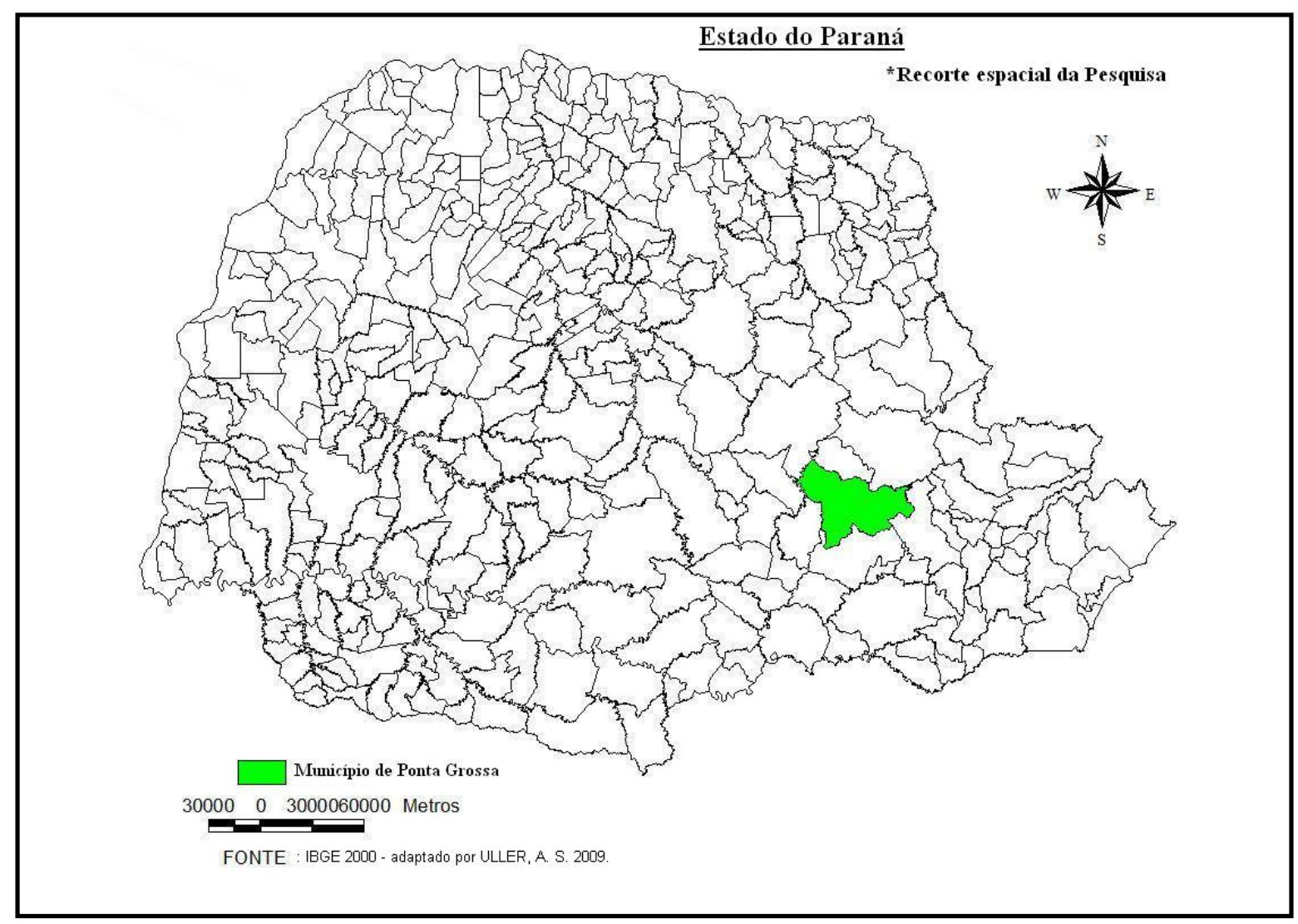


Ponta Grossa é um município com 187 (cento e oitenta e sete) anos e conta com mais de trezentos mil habitantes. Sua localização geográfica é bastante estratégica, como um dos principais entroncamentos rodoferroviários do Estado do Paraná.

Junto com mais 24 municípios, Ponta Grossa integra a região denominada Campos Gerais, localizada na parte meridional do segundo planalto paranaense.

\section{Mapa 18: Localização de Ponta Grossa - Região dos Campos Gerais}

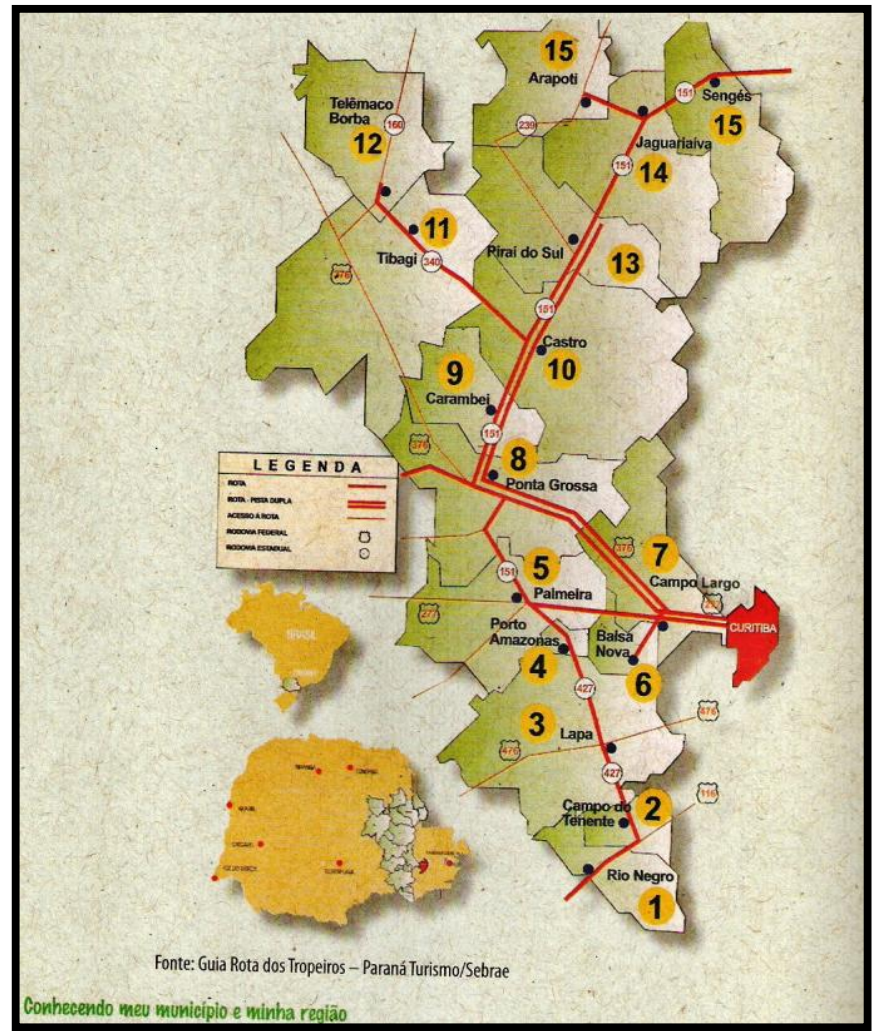

Fonte: Prefeitura Municipal de Ponta Grossa. Turismo, 2007.

No mapa anterior é possível observar a área que nos referimos, denominada Campos Gerais, sua abrangência no território paranaense e a localização de Ponta Grossa nessa região, que apresenta como característica própria de, não só apresentar condições físico-territoriais compostas por grandes 
potencialidades de belezas naturais, mas também, sua condição econômicohistórico-cultural, praticamente interconectada, com forte presença das culturas eslavas (poloneses, ucranianos, holandeses, russos-alemães), do pioneirismo originado pelo caminho das tropas, e por uma economia agrícola bastante desenvolvida.

Visto que Ponta Grossa está distante 120 km da capital, Curitiba, sendo entroncamento rodoferroviário, salientamos que esses fatores fazem com que a mesma tenha um grande fluxo de pessoas que passam diariamente por este trecho, com destino ao sul ou norte do país. Muito desse fluxo, pode ser aproveitado como visitantes turísticos em potencial, desde que haja as condições de atração e acomodação dos mesmos, dando condições de circulação e localização pelo município, para tanto, faz-se necessário uma política pública bastante arrojada para este setor, de modo a fazê-lo desenvolver como um todo, e não apenas tendo um mero "símbolo representativo" de sua capacidade turística.

\subsubsection{A política pública interna voltada ao turismo}

Apesar de apresentar grande parte das condições de acolher o turista do ponto de vista estrutural, ficamos muito a desejar no sentido de receptividade e organização administrativa para atendê-los, face a falta de informações deste 
serviço, e carência de material para aqueles que desejam ficar na cidade e visitar as localidades, mesmo que de modo independente de guia.

Aqui destacamos um aspecto que nos chocou ao visitar o posto de informações turísticas. A professora que nos atendeu apresentou como estratégia de informação aos visitantes, espécie de bilhetes descritivos, feitos a mão, em verso de folhetins de propaganda comercial. Isto porque não se tem um serviço próprio de acompanhamento destes visitantes, e com o único material que eles dispões para localização (material 1, anexo 4), os turistas não se sentem seguros, para se deslocarem pelo território da cidade. Assim, são feitos estes "bilhetes descritivos", para não deixar os turistas na mão, que não querem voltar sem conseguir fazer qualquer visitação. Alguns destes "bilhetes", foram por nós coletados e fotografados, para demonstrar como isso é feito na prática.

Figura18. Exemplos de bilhetes descritivos das localidades turísticas.

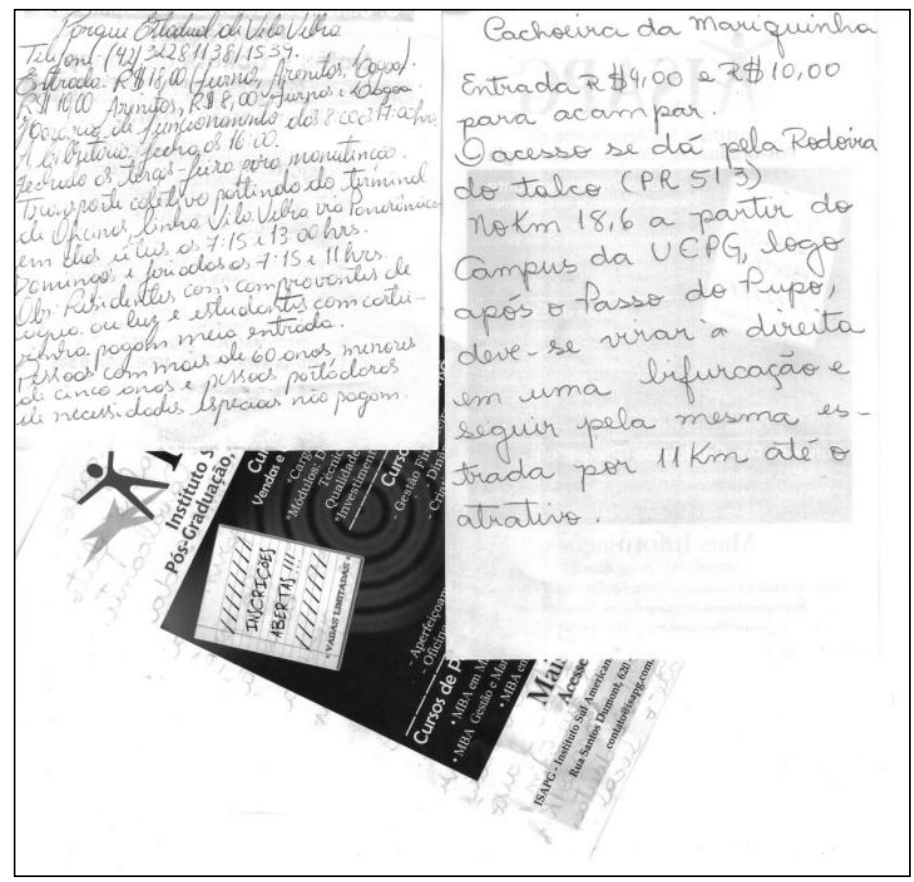

Fonte: Posto de Informações Turísticas de Ponta Grossa. 
Como se pode verificar, o posto de informação se dá ao trabalho de descrever detalhadamente cada um dos locais, demandando tempo tanto do atendente (que na ocasião só contava com um), como tempo do turista que poderia ser utilizado para visitação.

$\mathrm{Na}$ ocasião dessa entrevista, dialogamos sobre esta indignação enquanto moradora de uma cidade que pouco tem se preocupado com este serviço: "É uma pena uma cidade como a nossa, com grande potencial turístico, não ser valorizada" (relado da professora entrevistada).

Diante desta realidade, buscamos verificar mais a fundo essa demanda por mapas e as alternativas utilizadas em detrimento a esse descaso, que se torna por sua vez responsável pela patologia que é identificada como "cartofobia" por Monmonier.

\subsubsection{Uma Cartofobia coletiva?}

A "metáfora" que intitula este espaço de análise vem de encontro com o "paradoxo" apresentado no que segue, onde é possível verificar que há um dualismo entre os que se utilizam de mapas e os que preferem não fazer uso destes.

Assim como Monmonier, temos realmente com o uso dessa expressão, o propósito de chocar, ou seja, enfatizar amplamente este fato, no sentido de se 
fazer necessário refletir sobre o que isso afeta na valorização de uma produção de mapa local.

Gráfico 6: Formas de localização espacial que os visitantes utilizam

Para se localizar durante sua visitação aos lugares você costuma se utilizar de :

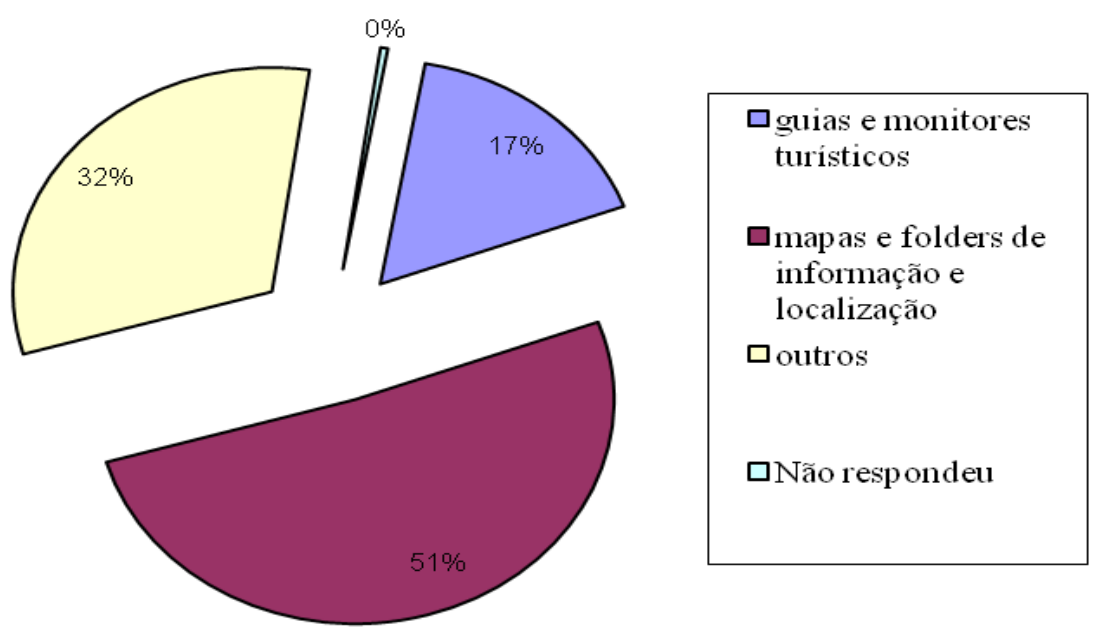

Fonte: organização de ULLER, A. S., 2010.

Nos chamou bastante a atenção o fato que muitas pessoas entre os entrevistados afirmarem se guiar perguntando a quem já foi, e até mesmo dizer que, vão por "rumo". Aí nos indagamos se isto seria um verdadeiro sintoma de "cartofobia".

Abaixo ilustramos novamente (outro exemplar), a cópia de um dos meios informativos, escrito à mão, no centro de informação turística do Município onde 
destacamos os referenciais de localização, utilizados na descrição, orientação esta, diferente das convenções utilizadas pela Cartografia, mas que está imbutida através do senso comum de lateralidade, juntamente com a escala em distâncias quilométricas ${ }^{41}$ :

\begin{abstract}
"Represa dos Alagados: O acesso ao local é feito pela Avenida Carlos Cavalcanti. Em frente ao CAMPUS da UEPG entra na primeira rua à esquerda. Na próxima rua dobra à direita. $O$ acesso se dá pela rodovia Ariclenes Carlos Gobbo (deve-se virar à esquerda, após passar o pátio da $A_{L L}{ }^{42}$ em direção ao Núcleo Dal Col. Após percorrido $2 \mathrm{Km}$, deve-se virar à direita, após o matadouro municipal, e por baixo da linha férrea. Segue $5 \mathrm{~km}$, vira à esquerda, por mais $1 \mathrm{~km}$,até uma bifurcação. Vire à direita. São mais dois $\mathrm{km}$ até o local" (grifo nosso)l.
\end{abstract}

Além dessa forma pitoresca de se obter informações de localização, outra questão que se põe, diante da observação das respostas de muitos sujeitos, é o uso popularizado da internet, que muitas vezes é acessada, também com a finalidade de se pesquisar localidades de visitação, em momentos que pretendem programar um passeio ou uma temporada de férias.

Não podemos negar as inúmeras vantagens deste meio de informação, via internet: a agilidade e interatividade, a atualização dos dados, visualização geral e específica, possibilidade de impressão ou arquivamento das informações. Porém, nem sempre se dispõe destes artifícios numa passagem inesperada por um local

\footnotetext{
${ }^{41}$ Na situação descrita nos sentimos trabalhando com a alfabetização cartográfica, com referencial em Simielli, onde necessitamos repassar às crianças uma compreensão entre os dados reais e as convenções utilizadas no mapa correspondentes. Porém nos questionamos se para turistas, geralmente adultos, precisaria de uma linguagem tão precária para suprir a necessidade de informar as localidades, ou se isto poderia facilmente ser substituído por um mapa turístico bem elaborado.
}

\footnotetext{
${ }^{42}$ América Latina Logística. Empresa que trabalha com transporte ferroviário comercial.
} 
que desconhecia, e que de repente, um outdoor na estrada lhe chama a atenção como num convite para se visitar.

A demanda por material, contudo está evidente, conforme os próprios entrevistados relatam: "O folder é importante, porque atrai o turista que sempre se guia pelo mapa" (entrevistado 30$)^{43}$.

Os mesmo entrevistados são também capazes de perceber a diferença de qualidade informativa, entre dois materiais distintos, ainda que não dominem a linguagem cartográfica apropriada: “A carta 1 contém fotos interessantes, porém a diagramação não é muito clara. Já a Carta 2, embora não contenha fotos, a diagramação é muito melhor" (entrevistado 25).

Em outros materias, encontrados como divulgação especial de eventos, observamos a identificação de pontos de referência como meio articulador desta orientação, neste caso, que ilustramos a seguir, o mapeador destaca as saídas da cidade, bem como os entroncamentos de viadutos, o centro, e o ponto de interesse para o evento (Centro de Eventos).

Percebe-se que mesmo neste tipo de material, dá-se a importância para Vila Velha, como único ponto turístico mencionado. O que fortalece nossa hipótese de que muitos apenas vem para esta localidade, visitam Vila Velha e retornam, não se dirigindo aos demais atrativos, que poderiam ser mencionados mas não são.

\footnotetext{
${ }^{43}$ Utilizaremos como identificação dos entrevistados a numeração que atribuímos a cada ficha, para resguarda-los em sua privacidade.
} 
Mapa 26: Mapa Publicitário do "Centro de Ponta Grossa"

\section{Mapa - Centro e saídas da cidade de Ponta Grossa}

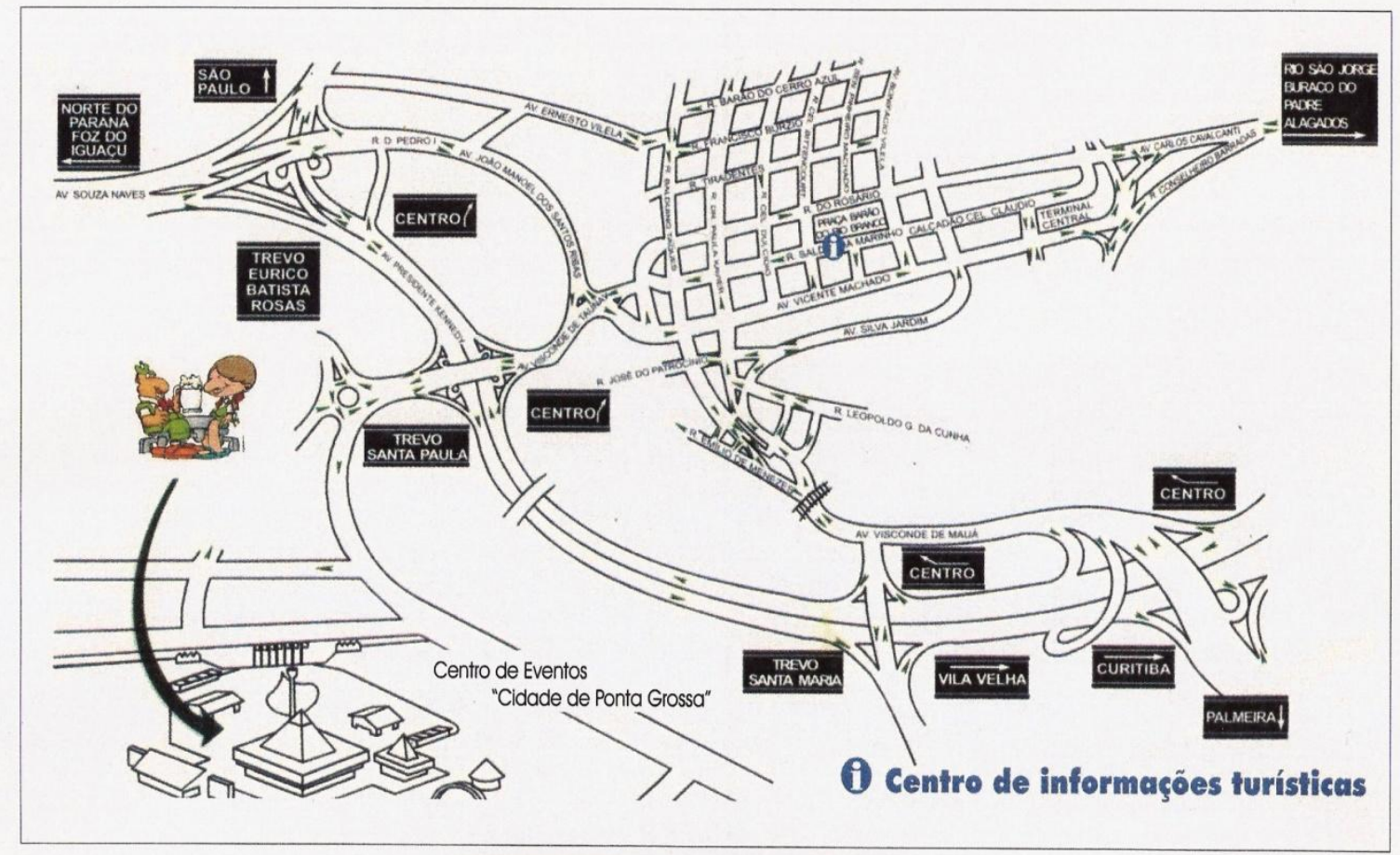

\section{PONTA GROSSA \\ nossa vida acontece aqui.}

Fonte: Prefeitura Municipal de Ponta Grossa

Destacamos o título desse mapa anterior, que é identificado como sendo sobre o centro de Ponta Grossa, mas que na verdade traz apenas algumas rotas estratégicas a se percorrer para entrar na cidade, chegar ao evento, se deslocar por algumas ruas principais, e saídas rumo ao norte ou sul do Estado, com o destaque para a localização de Vila Velha que fica numa destas rodovias.

Neste sentido é que se torna vital a necessidade de um documento gráfico (mapa) impresso à disposição do turista de modo a auxilia-lo em sua orientação espacial. Este é o nosso interesse em atribuir grande valor à um mapa turístico 
bem elaborado, eficiente e prático, ao acesso de "todos" que necessitarem de apoio para se localizar durante o percurso naquela localidade, pois as pessoas não tem os mesmos interesses, e por mais que venham para o Município a fim de um evento em específico, não se pode limitar as suas possibilidades de conhecer outros aspectos.

Vale aqui lembrar, que mesmo com toda a "parafernália eletrônica" atual: computador, internet, palm, GPS, não tem como se dispensar o tradicional mapa, como velhos escoteiros desbravando áreas inóspitas ${ }^{44}$.

3.2.4. Aprofundando a investigação sobre a qualidade dos mapas turísticos ofertados

Articulando a prévia constatação da demanda de material cartográfico ratificamos nosso interesse a respeito, questionando com particularidade sobre este aspecto.

Uma das questões de nossa investigação focava sobre a importância que as pessoas atribuem ao material cartográfico, se sentem necessidade de um mapa, ou se consideram um produto irrelevante e dispensável, que não carece de preocupações dos gestores públicos, responsáveis pela viabilização de suprimento das necessidades da comunidade local.

\footnotetext{
${ }^{44}$ Áreas de difícil acesso.
} 
$\mathrm{Na}$ sequência, apresentamos um gráfico que ilustra o resultado dessa verificação, disposta numa questão com quatro variáveis de respostas. Vale destacar, que aqui aproveitamos a questão para investigar se os turistas haviam contato com algum daqueles materiais que estávamos demonstrando.

Gráfico 7: Considerações particulares sobre materiais cartográficos turísticos

\section{Quanto ao material cartográfico sobre atrativos turísticos do município:}
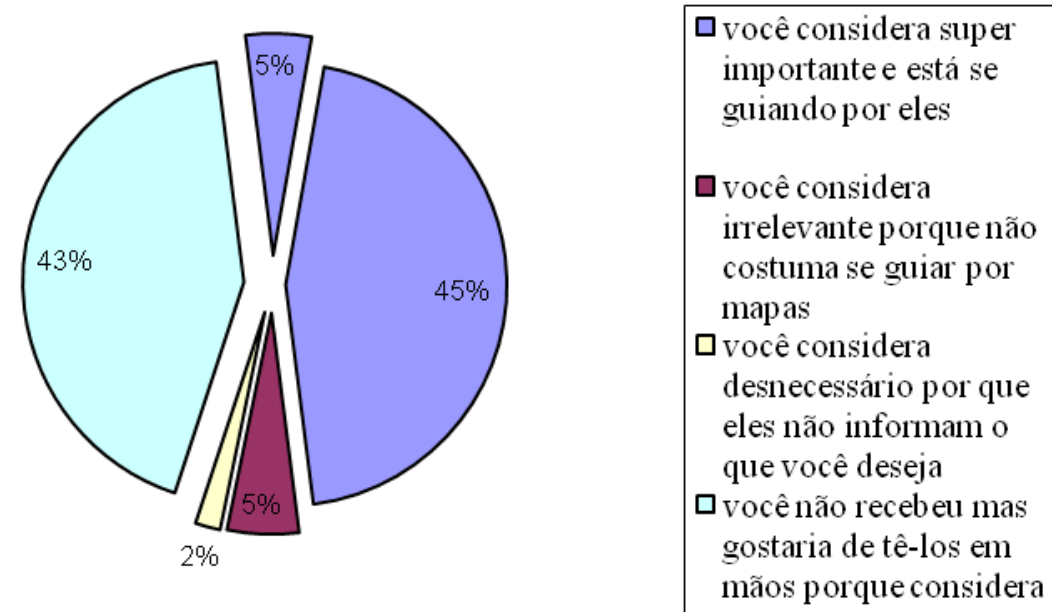
importante e está se guiando por eles

$\square$ você considera irrelevante porque não costuma se guiar por mapas

$\square$ você considera desnecessário por que eles não informam o que você deseja

$\square_{\text {vocênão recebeu mas }}$ gostaria de tê-los em mãos porque considera importante

Fonte: organização de ULLER, A. S., 2010.

Nas respostas obtidas é possível visualizar um grande equilíbrio entre a valorização das pessoas pelo mapa, bem como a demanda e insatisfação por não encontrar os mesmos materiais turísticos disponibilizados para o uso de todos. 
Quanto à análise do mapa propriamente dito, buscamos primeiramente todos os exemplares existentes na secretaria de turismo, e verificamos que a princípio, há pouco arquivo desses materiais, sendo muitas vezes reproduzida a amostra feita como "croqui", em detrimento do mapa mais atualizado. Tentamos indagar o porquê, e não conseguimos muita resposta. Acreditamos que talvez seja por motivo de licitações, ou custo diferenciado entre a produção dos materiais.

Mapas 272 28: Mapas turísticos antigos de Ponta Grossa

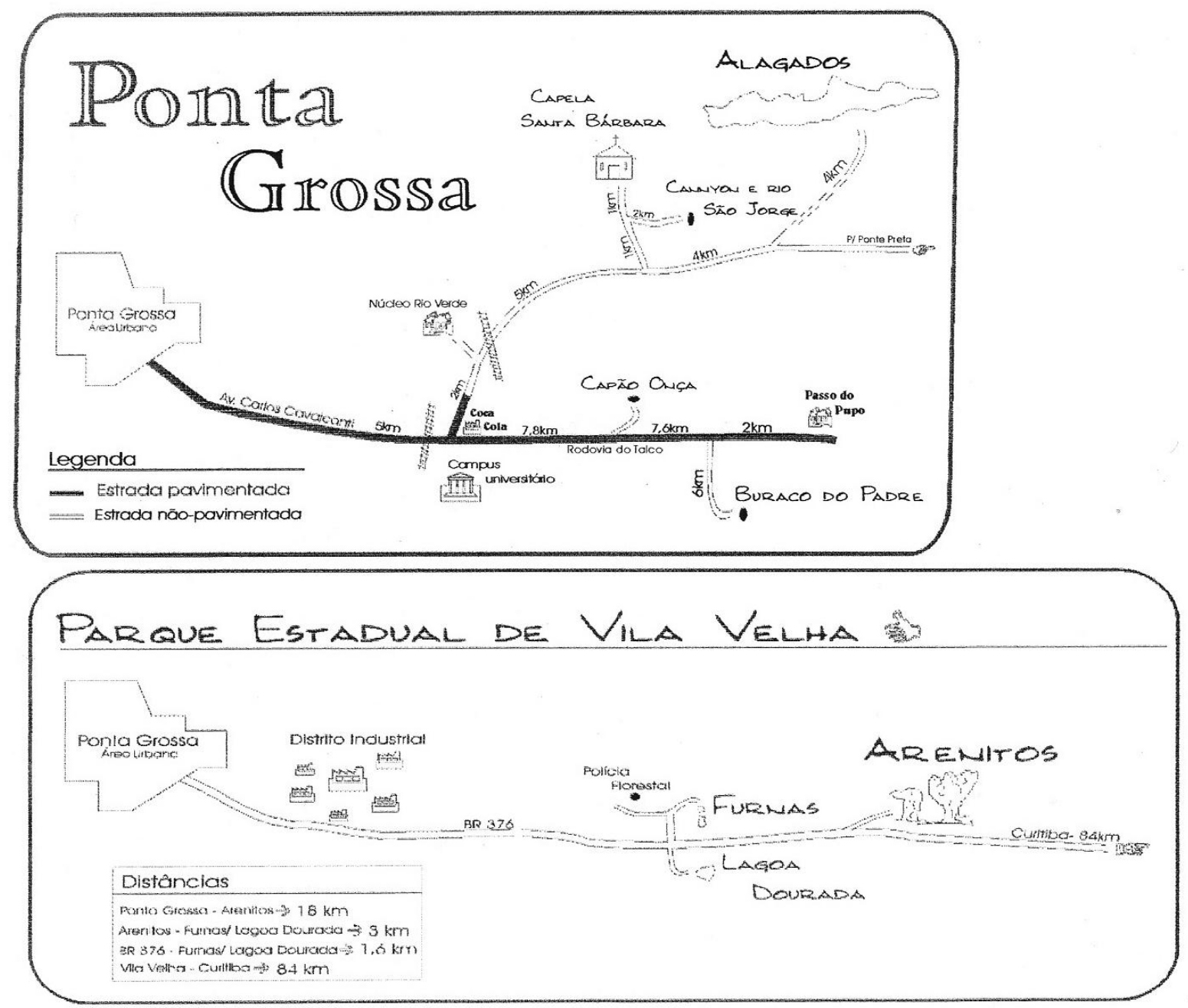

Fonte 
Os exemplares expostos, foram identificados pela Secretaria Municipal de Turismo de Ponta Grossa, como "mapas turísticos mais antigos". Poderíamos aqui chamá-los de ensaios cartográficos ou croqui, onde provavelmente o autor ${ }^{45}$ do mesmo, não deva possuir nem capacitação profissional referente à área e nem recursos técnicos de mapeamento, pois além das irregularidades nas distâncias, que não aparecem como escala, também se observa que determinadas localidades foram inseridas a mão de modo meio aleatório, num fazer analógico sem muito rigor, como numa espécie de correção de rascunhos.

Não estamos aqui discordando da ideia do fazer cartográfico partir de um critério analógico, pois sabemos a preciosidade desse saber-fazer, que permite ao produtor de mapas um pleno conhecimento do produto que está sendo elaborado, porém, este mapa é ainda utilizado nos dias de hoje, com mínimas alterações na imagem visual em relação a cor, mas ainda totalmente carente de muitos requisitos essenciais, como: escala, orientação e legenda.

Selecionamos entre os materiais existentes os dois últimos elaborados. Um que reproduz esse "croqui", demonstrado anteriormente, e que é o material disponível aos turistas, acreditando ser mais "enxuto e prático", e outro, mais elaborado, cheio de informações, em escala maior, e num papel reciclado, feito pelo mapeador que conseguimos identificar e até mesmo entrevistá-lo (ver anexos). Ambos materiais foram utilizados como referencial para investigação, nos questionários aplicados aos visitantes.

\footnotetext{
${ }^{45}$ Não conseguimos informações sobre a autoria do mapa, e nenhuma identificação de fonte no próprio material.
} 
Na sequência apresentamos uma cópia reduzida de cada um dos mapas, para ilustrar e facilitar a identificação dos mesmos, no material em anexo.

Mapa 29 - Ponta Grossa - Um encontro de caminhos (correspondente ao material 1 da pesquisa)

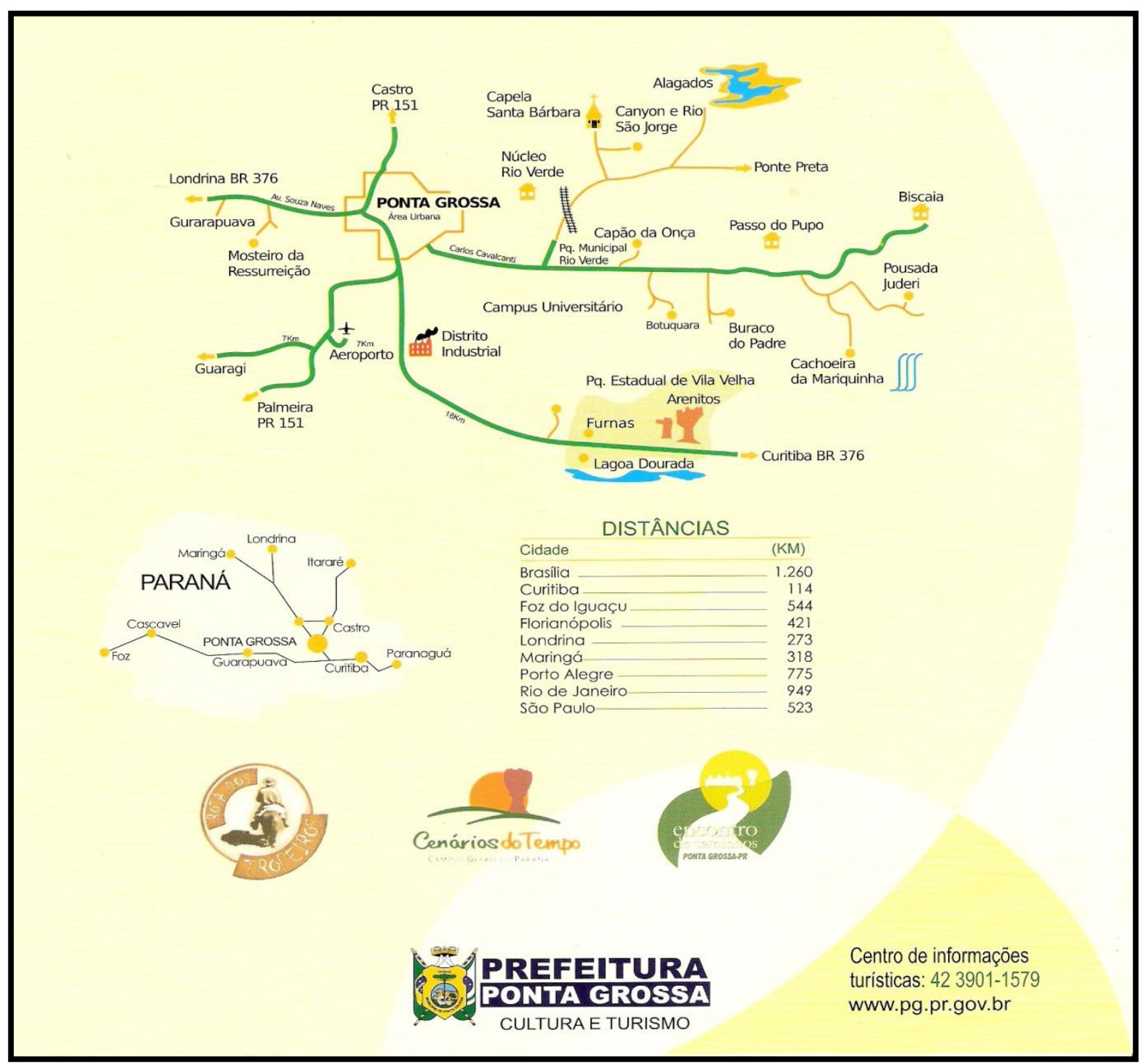

Fonte: Secretaria Municipal de Indústria, Comércio e Turismo de Ponta Grossa 
Mapa 30 - Mapa Turístico de Ponta Grossa

(correspondente ao material 2 (dois) da pesquisa)

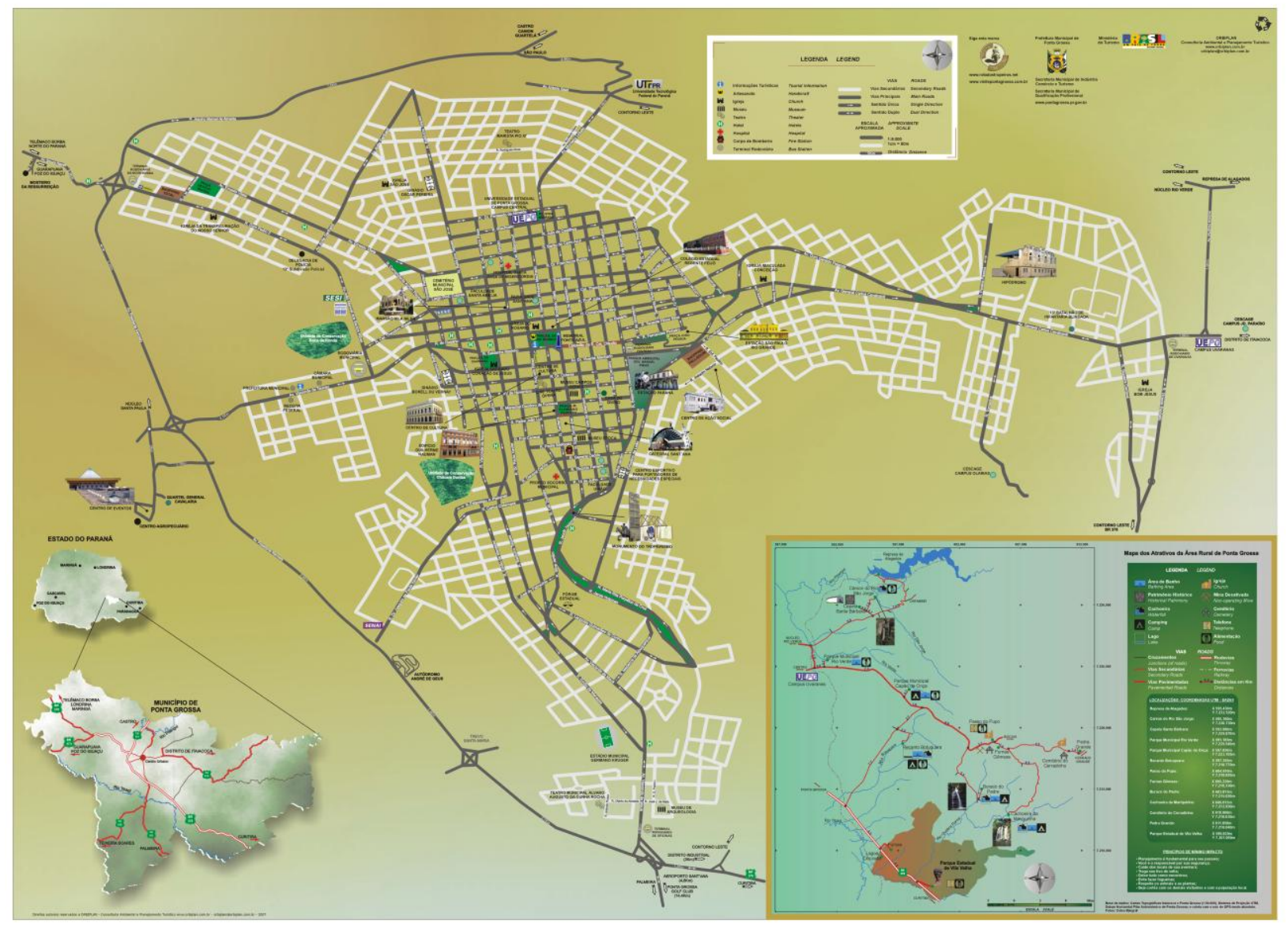

Fonte: Fonte: Secretaria Municipal de Indústria, Comércio e Turismo de Ponta Grossa

Para cada um dos mapas, aplicamos as mesmas perguntas a respeito de quinze atributos observados, especificamente, sendo anteriormente questionado sobre a opção qualitativa entre ambos os materiais numa visão geral, conforme viemos relatando anteriormente neste capítulo que narra sobre a parte prática de nossa pesquisa. 
Na sequência apresentamos o gráfico da questão que sugeria a escolha de um dos materiais, como sendo o mais adequado ao interesse do turista.

Gráfico 8: Avaliação da preferência entre os dois materiais turísticos de Ponta Grossa

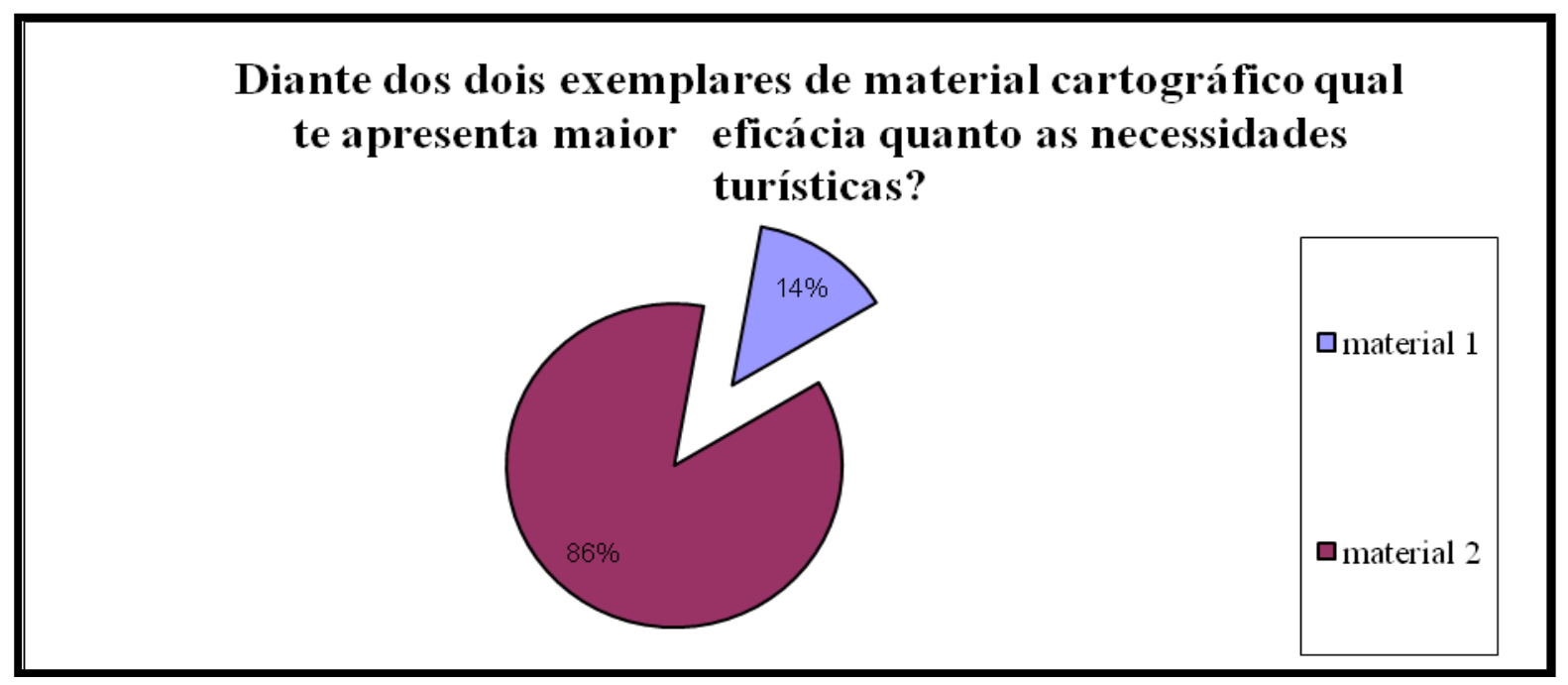

Fonte: organização de ULLER, A. S., 2010.

É drasticamente grande a diferença de valoração dos materiais no aspecto geral. Isto foi revisto no caráter específico para compreender o que mais tem relevância para o usuário no momento em que ele se depara com o mapa.

Entre as considerações pertinentes dos entrevistados, encontramos como destaques, subjetivamente elencados de modo repetitivo, as vantagens e desvantagens de cada um dos materiais.

Apresentamos tais considerações listadas nos quadros que seguem, juntamente com algumas outras observações relatadas pelos entrevistados: 
Quadro 3: Considerações qualitativas sobre o Mapa 1:

\begin{tabular}{|l|l|}
\hline \multicolumn{1}{|c|}{ VANTAGENS } & \multicolumn{1}{c|}{ DESVANTAGENS } \\
\hline $\begin{array}{l}\text { De melhor entendimento, compreensão, por ser } \\
\text { mais simples e mais resumido }\end{array}$ & Poucos detalhes \\
\hline Objetivo e prático & Não trás informações sobre serviços \\
\hline Tamanho reduzido e mais fácil de manusear & $\begin{array}{l}\text { Não apresenta o nome das ruas para facilitar o } \\
\text { acesso }\end{array}$ \\
\hline Informa rapidamente & $\begin{array}{l}\text { Não apresenta escala, para facilitar a a } \\
\text { percepção exata das distâncias entre um ponto } \\
\text { turístico e outro }\end{array}$ \\
\hline Mais colorido & \begin{tabular}{l} 
Apenas um idioma \\
\hline
\end{tabular} \\
\hline
\end{tabular}

Fonte: organização de ULLER, A. S., 2010.

De modo geral, observamos que a maioria das pessoas não desqualificavam totalmente o material 1 , mesmo encontrando problemas no mapa: "em questão de diagramação o primeiro material está muito bom, porém não apresenta informações suficientes sobre os pontos turísticos que permita conduzir o visitante até os locais desejados" (entrevistado 58).

Apontaram muitas vezes como vantagem, a praticidade pelo tamanho, e também por ser mais limpo de informações, facilitando com isso a leitura: "o material 1 possui uma ilustração bem apresentável, em papel de qualidade, com fotos produzidas, e bem prático de manusear, pois é menor" (entrevistado 8); é

\footnotetext{
${ }^{46}$ No caso das escalas de distâncias Monmonier explica um detalhe a se observar sempre, para não fazer uma leitura fiel mesmo em mapas que apresentam tal escala, principalmente se esta for muito reduzida:

"Mapas que atendem aos padrões mostram somente a distância planimétrica, ou seja, a distância medida em um plano... um mapa planimétrico comprime a superfície terrestre tridimensional em uma carta bidimensional ao projetar perpendicularmente cada ponto em um plano horizontal. Para dois pontos em diferentes altitudes, a distância cartográfica entre suas posições "planimetricamente rigorosas" subestima ambas a distância terrestre em toda a superfície do terreno e a distância em linha reta nas três dimensões" (1996; idem).
} 
bem fácil de encontrar os lugares turísticos neste mapa, é como se tivessem filtrado só isso nele" (entrevistado 450).

Quanto às desvantagens, o que mais sobressaiu nas observações, foram justamente as queixas de maiores detalhes das ruas, para conseguirem se localizar: "o mapa 1 é muito sintetizado, não oferece ao turista, que tem uma visão espacial limitada, o conhecimento suficiente para elaborar um roteiro em sua mente" (entrevistado 73), complementada com "assim o material deixa de promover a vontade de visitação ao local, pois não favorece uma facilidade de realização entre o querer ir e o conseguir chegar" (entrevsitado 253).

Salientam que tal mapa é de maior utilidade para quem já reside em Ponta Grossa, mas não para turista de fora: "o material 1 talvez seja muito bom para os moradores da cidade e regiões vizinhas, que já conhecem um pouco o lugar, mas necessita de muito mais detalhes para turistas vindos de longe e que nunca passaram por aqui" (entrevistado 93).

Também assinalam que para um mapa turístico, falta muitas informações importantes: " no material 1 não encontra-se informações de hospitais e outros serviços de extrema importância" (entrevistado 111), "o material 1 não traz informações sobre locais de acomodação para o turista" (entrevistado 84).

Percebemos com tais depoimentos, que as pessoas não precisam de tanto conhecimento na área para enxergar a necessidade de um mapa, e mais ainda, para perceber requisitos importantes que neve constar em um material desse gênero: "no material 1 nota-se uma escassez de informações". (entrevistado 115), "o mapa 1 é indicado para pessoas que já possuem um conhecimento prévio da região, poderia conter mais informações sobre terminal de ônibus, melhor caminho a percorrer" (entrevistado 316, 322). 
Quadro : Considerações qualitativas sobre o Mapa 2

\begin{tabular}{|c|c|}
\hline VANTAGENS & DESVANTAGENS \\
\hline Mais especificada a localização & Poluído de informações \\
\hline Mais informativo & Fotos apagadas \\
\hline Bastante abrangente & Deveria ser mais colorido \\
\hline $\begin{array}{l}\text { Transmite outros conhecimentos descritivos } \\
\text { sobre os lugares }\end{array}$ & $\begin{array}{l}\text { Difícil manuseio por ser muito grande } \mathrm{e} \\
\text { precisar de dobras }\end{array}$ \\
\hline Bastante detalhado & Necessidade de consultar o verso \\
\hline \multicolumn{2}{|l|}{ Apresenta ótima legenda, mais detalhada } \\
\hline \multicolumn{2}{|l|}{ Mais ilustrativo } \\
\hline \multicolumn{2}{|l|}{ Bilingue } \\
\hline \multicolumn{2}{|l|}{ Mais explicativo } \\
\hline \multicolumn{2}{|l|}{ Prático } \\
\hline \multicolumn{2}{|l|}{ Atrativo } \\
\hline \multicolumn{2}{|l|}{$\begin{array}{l}\text { Escala Grande, porém abrangendo as } \\
\text { rodovias e também as avenidas principais }\end{array}$} \\
\hline \multicolumn{2}{|l|}{ Papel Reciclado (consciência ambiental) } \\
\hline \multicolumn{2}{|l|}{$\begin{array}{l}\text { Apresenta localidades de serviços importantes } \\
\text { de interesse do turista }\end{array}$} \\
\hline \multicolumn{2}{|l|}{$\begin{array}{l}\text { Mostra tanto o centro quanto as áreas mais } \\
\text { periféricas }\end{array}$} \\
\hline \multicolumn{2}{|l|}{$\begin{array}{l}\hat{E} \text { realmente um mapa e não só uma } \\
\text { propaganda dos lugares }\end{array}$} \\
\hline \multicolumn{2}{|l|}{$\begin{array}{l}\text { Permite uma melhor orientação pois traz o } \\
\text { nome das ruas e os meios de acesso, ou seja, } \\
\text { permite fazer um trajeto mental }\end{array}$} \\
\hline \multicolumn{2}{|l|}{$\begin{array}{l}\text { O tamanho permite que as distâncias entre } \\
\text { uma localidade e outra sejam melhor } \\
\text { percebidas }\end{array}$} \\
\hline \multicolumn{2}{|l|}{$\begin{array}{l}\text { Escala permite perceber as distâncias em } \\
\text { quilometragem entre um lugar e outro }\end{array}$} \\
\hline \multicolumn{2}{|l|}{$\begin{array}{l}\text { Descreve ass potencialidades de lazer de } \\
\text { cada localidade (ponto turístico) }\end{array}$} \\
\hline \multicolumn{2}{|l|}{$\begin{array}{l}\text { Permite que o turisto possa ser um sujeito } \\
\text { independente no processo de visitação }\end{array}$} \\
\hline \multicolumn{2}{|l|}{$\begin{array}{l}\text { Melhor visualização que permite uma } \\
\text { sensação de que a cidade seja organizada }\end{array}$} \\
\hline $\begin{array}{l}\text { Percebe que o turista é um sujeito de fora, } \\
\text { sem informações sobre o local e muitas vezes } \\
\text { é até estrangeiro }\end{array}$ & \\
\hline
\end{tabular}

Fonte: organização de ULLER, A. S. 2010. 
Indiscutivelmente, este material é apontado pelos entrevistados como mais eficiente diante das inúmeras vantagens em detrimento do outro anteriormente comentado.

Algo que logo de início era constatado pelos usuários se referia a riqueza de informações: "O mapa 2 está mais completo, assim os turistas terão mais facilidade para entender e compreender a leitura do mapa, podendo encontrar os lugares sem problemas”. (entrevistado 134)

Os mesmos entrevistados, por vezes, justificavam suas considerações apontando até mesmo, novas perspectivas:

"Quanto mais bem informado estiver o visitante, despertará o interesse em conhecer os locais apresentados no mapa. Portanto o material 2 possibilita identificar muitos pontos turísticos desconhecidos da maioria da população pontagrossense, imagina de outros municípios dos Campos Gerais e até de outras localidades. Seu trabalho será de grande valia" (entrevistado 184)

Além do mapa em si, foi muito valorizado o aspecto do material como um todo, por ser de utilidade turística, visto que trazia outros complementos que favoreciam:

"O material 2, como um todo, é mais detalhado. Se eu estivesse vindo pela primeira vez à cidade poderia melhor escolher quais lugares conhecer, ou seja, visitar os pontos mais voltados ao meu interesse, pois no próprio folder se apresenta além de um mapa bastante amplo e completo, toda uma contextualização descritiva de cada lugar". (entrevistado 126) 
Percebemos que as considerações, fazem uma distinção de necessidades diante do material, entre o morador local, com os visitantes de longe: "O mapa 2 está mais completo. O Turista, por não conhecer o local, precisa de mapas completos, onde eles possam obter todas as informações que precisam. Já para os moradores locais já não é preciso informação muito detalhada" (entrevistado 132).

Os mesmos, ainda observam a importância de atender ao turista de outros países: "o material 2 além de apresentar uma riqueza de informações, também traz a utilidade bilingue, que é bastante útil aos turistas do exterior (entrevistado 115)

Além das observações positivas, também foram obtidas críticas bastante relevantes: "possui várias informações que proporcionam facilidade para chegar aos locais a serem visitados, entretanto possui um material de 'baixa qualidade', com difícil manuseio e com ilustrações de frente e verso de ponta-cabeça" (entrevistado 282). Neste caso, é aferido qualificação para o papel em si, que não era nosso foco principal, mas que nos chama a atenção, visto que enquanto alguns veem o papel reciclável como um qualificador, outros ainda não conceberam esta consciência de preservação ambiental. Chamou-nos a atenção para o detalhe apontado quanto ao tamanho do material, que ao mesmo tempo que facilita, por comportar mais informações, outras vezes pode complicar, principalmente quando se tem que fazer consultas no seu verso.

Outros entrevistados, também se referiram, como crítica, ao excesso de informações, alegando certa poluição visual: "o material 2 é bem mais completa, mas chega a ser de difícil entendimento por conter tanta informação" (entrevistado 
111). Alguns, explicam em suas narrativas, que face à necessidade de colocar muitas informações no mapa, a letra ficou muito pequena: "o material 2 é mais completo, apenas achei que as letras das informações poderiam ser maiores, pois há pessoas que não as enxergariam (entrevistados 316, 322).

Citaram diversas vezes, a crítica sobre não encontrarem este material impresso, disponibilizado: "Realmente falta ainda muitos materiais deste gênero". (entrevistados 15, 32, 96, 124, 209, 257, 299, 326, 408 e outros que adicionaram mais observações). Justificaram suas considerações: "O material 2 é excelente, contém informações precisas e práticas para auxiliar o turista na localização dos pontos turísticos e demais serviços na cidade. Deveria ser um material de fácil acesso a todos" (entrevistado 327); e tentaram até buscar razões disso: "O material 2 é bem mais completo;: Tem um resumo bom de cada ponto turístico, mas acho que não é muito divulgado por ser um material de maior custo financeiro" (entrevistado 273).

Entre as disposições sugeridas para um melhor produto cartográfico e aproveitamento do mesmo, viabilizando uma política de turismo, bastante favorável ao desenvolvimento da cidade e atração do visitante, os entrevistados destacaram: "A região de Ponta Grossa, é muito rica em atrações turísticas e tem um grande potencial, porém, há necessidade de dinamização das informações e estrutura, ou seja, um interesse político voltado para o setor" (entrevistado 335).

Nesse sentido se remetem à valorização do material de apoio ao turista: "Nossa região possui belezas naturais maravilhosas e este tipo de material bem feito, bem construído, é muito importante, não só para a divulgação, como 
também para uma forma de orientação correta de visitação nestes lugares" (entrevistado 334).

Fazem menção quanto à necessidade de atender ao visitante estrangeiro nesse material: "Pelo mapa 2, é mais fácil de se localizar, mas para melhorar o quesito de internacionalização, deveria ser escrito também em espanhol, afinal grande parte de nossos turistas são dos países vizinhos" (entrevistado 354).

E ainda, vão além, se preocupando com a situação dos deficientes, sujeitos especiais que requerem de uma atenção maior:

\footnotetext{
"estas respostas as preenchi a partir de minha perspectiva, que enxergo, ando normalmente, escuto... mas me pergunto sobre como fica a acessibilidade para cadeirantes, a leitura de mapas para cegos, e todas as adaptações que se fazem necessárias ao ser humano nas suas necessidades especiais" (entrevistado 336).
}

Percebe-se que não precisa ocupar uma função no setor, ou ter uma capacitação profissional vinculada, para se reconhecer necessidades de um turista. Outra questão bastante relevante é que chegam a tecer comentários bastante interessados sobre a questão cartográfica em si: "As informações devem ser o mais simple e clara possível" (entrevistados 105 e 307), "o mapa 1 é mais prático, porém o mapa 2 é mais técnico" (entrevistado 327);

E ainda ousam utilizar palavras diversificadas do vocabulário comum, para atribuir considerações sobre este tipo de material e sobre a cartografia: 
"Mapas em flayers turísticos tem grande importância tanto para os que residem na cidade como para os turistas. A importância de conhecer atrativos turísticos pela cartografia é um 'escudo', um norte para desbravar as belezas naturais da região”. (entrevistado 288)

Como sugestão para políticas públicas de incentivo ao turismo os entrevistados destacam:

\begin{abstract}
"Adorei a idéia de uma maior preocupação com a divulgação dos lugares de beleza turísticas de nossa cidade. Como sendo natural de Ponta Grossa, sei que muitas pessoas desconhecem as belezas naturais que a região dos Campos Gerais pode oferecer". (entrevistado 54)
\end{abstract}

"O município deveria divulgar mais, inclusive como há nos grandes centros, colocar a disposição da população e dos turistas em geral um ônibus circular que percorresse todos esses lugares, dando assim condições para quem não possui condução própria, ou não conhece a cidade, poder também visitar" (entrevistado 274)

Temos que atrair nossos visitantes para o centro da cidade, para que eles conheçam o nosso comércio, e façam com que eles fiquem mais tempo em nossa cidade" (entrevistado 381)

Quanto à valorização dos mapas, sugerem: "Para cada local turístico deveria haver um ponto de distribuição do mapa com todos os tipos de informações" (entrevistado 41), e ressaltam que não precisa de grandes esforços para alterações do material em si: "O material 2 já está praticamente excelente, bastando colocar mais dados sobre balneabilidade nos locais com águas pluviais e por questões de segurança, como um quesito especial, alertar sobre horários com potencial risco para turistas" (entrevistado 50)

Houveram aqueles que apontaram para a necessidade das duas versões, resumida e abrangente: "Os materiais são muito bons, seria muito interessante a 
fusão dos dois num único material: um mais sintético e outro mais detalhado" (entrevistados 52, 74, 316, 322)... complementando... "ou a formação de uma espécie de kit turista" (entrevistado 187).

\subsubsection{Análise quantitativa sobre os mapas avaliados}

As estatísticas descritivas embasadas em Vieira Neto (2004), apontaram tais considerações sobre cada um dos mapas, onde retratamos as mesmas, através de gráficos de barras duplas, uma para cada material analisado, de modo em que possa dar visibilidade comparativa entre os resultados de cada questão avaliada.

Gráfico 9: Avaliação referente ao tamanho dos mapas

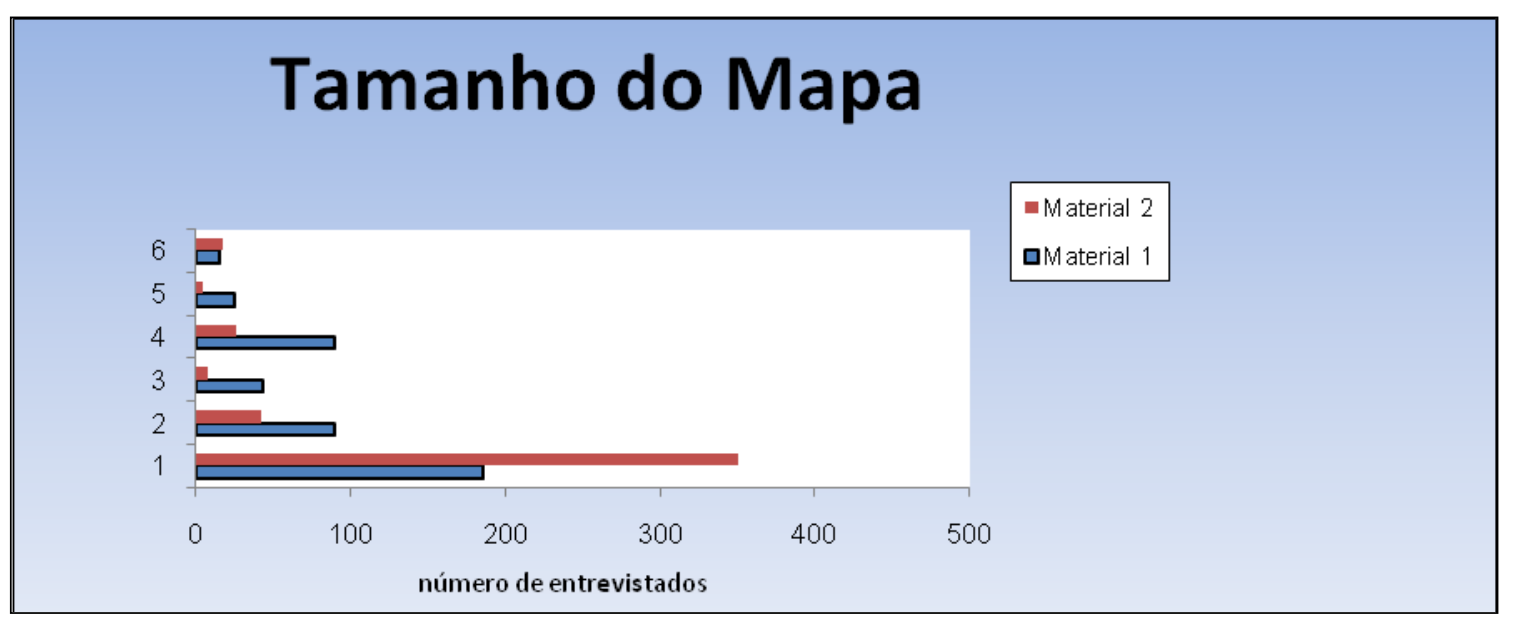

Fonte: organização de ULLER, A. S., 2010. 
Quanto ao tamanho, os entrevistado apreciaram os dois exemplares, com raras ressalvas. O material 2 , no entanto, se sobressai sobre o material 1 , em razão de que, por ser maior a sua escala, propicia a apresentação de mais detalhes.

Gráfico 10: Avaliação referente à disposição dos dados nos mapas

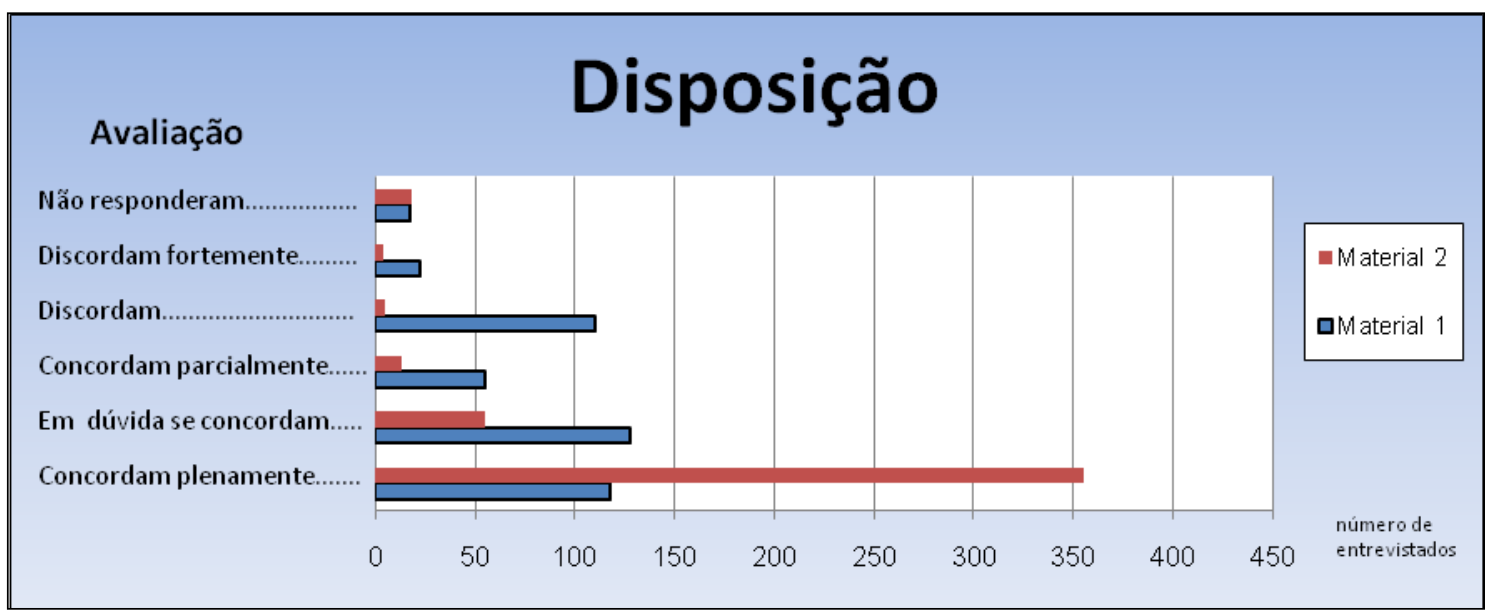

Fonte: organização de ULLER, A. S., 2010.

Referente à disposição dos dados, percebemos um posicionamento bastante favorável com relação ao material 2, visto que este além de trazer mais informações, distribui as mesmas de forma harmoniosa pelo espaço disponível do papel, organizando encarte, para localizar áreas periféricas, bem como legenda bem especificada. Já com relação ao material 1, houve um equilíbrio de opiniões entre os que concordam, e os que discordam, bem como, com relação àqueles que se sentiram em dúvida para opinar. Muitos alegaram não entender o modo de 
produção de mapas, outros não conhecerem a localidade, e com isso, ficaram sem saber o que dizer a respeito.

Gráfico 11: Avaliação referente ao tipo de ilustração

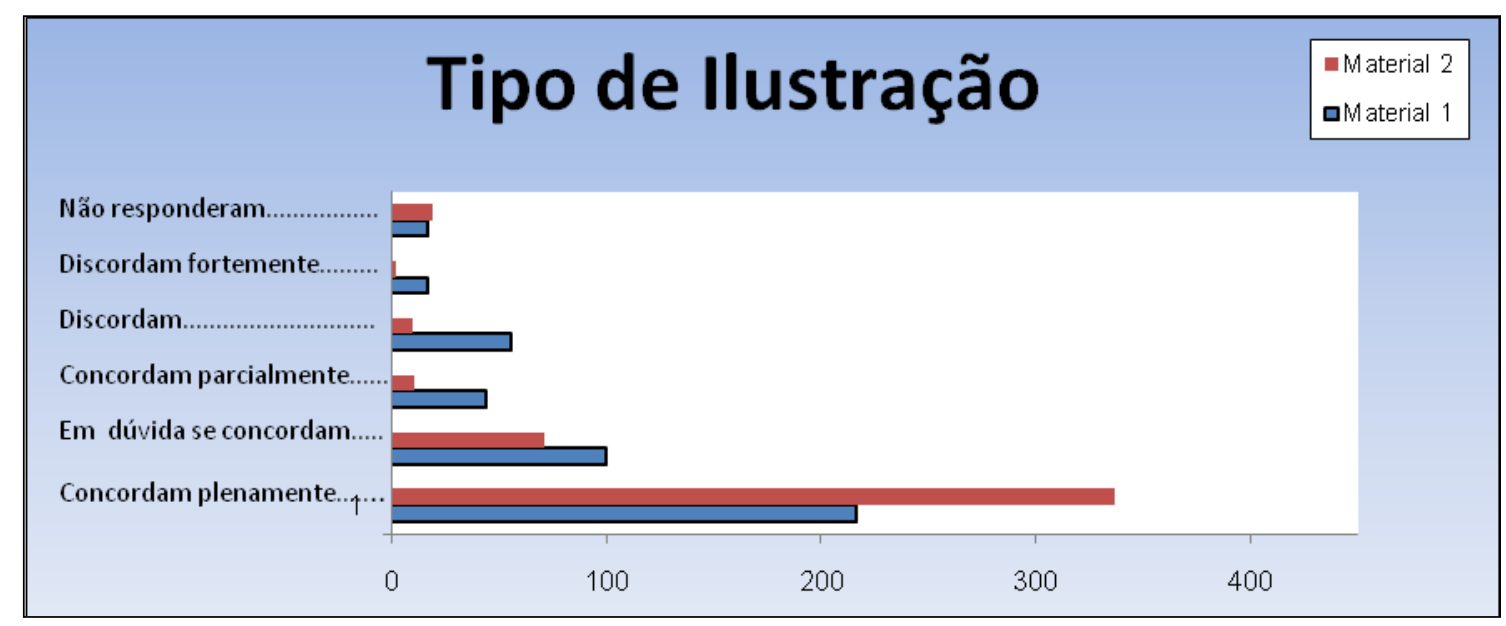

Fonte: organização de ULLER, A. S., 2010.

As ilustrações como sempre, são o grande chamariz dos mapas turísticos, porém, embora os elementos pictóricos e complementos de foto agradem alguns,por outro lado, há quem discorde dessa opinição, considerando que o mais importante é a veracidade das informações.

Neste gráfico visualizado acima, observamos entretanto que, apesar da avaliação ser preponderantemente positiva para ambos os mapas, novamente se aprecia mais o material dois, por atender às duas situações, de atração e informação. Ou seja, que a ilustração encante, a informação correta é essencial 
em todo e qualquer mapa, principalmente para fins de localização, conforme foi observado em questões seguintes que referem-se à esse atributo (gráfico 14).

Gráfico 12: Avaliação referente à escala dos mapas

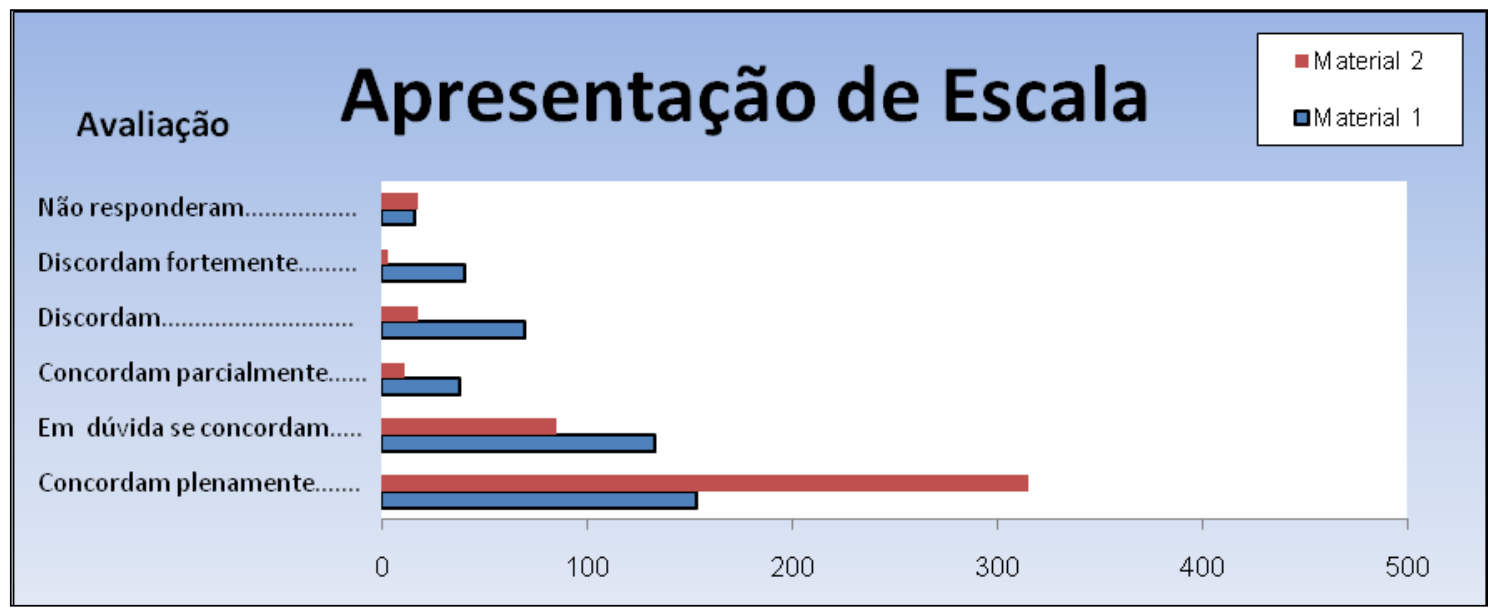

Fonte: organização de ULLER, A. S., 2010.

$\mathrm{Na}$ avaliação sobre a escala dos mapas, apesar de alguns não compreenderem como ela deve ser apresentada, e com isso ficarem em dúvida em como se posicionar frente à este quesito, outros conseguiram bem verificar que no mapa do material 2, é possível calcular as distâncias entre um ponto e outro, por cálculo mental da escala gráfica, que não aparece no mapa do material 1, que destaca apenas distâncias do Município em relação à algumas localidades de referência para quem é de outros lugares.

Apesar deste referencial contributivo, que possibilita saber a distância do município em relação à demais cidades e estado, se o mapa está tratando de 
uma localidade específica, é primordial que permita essa visualização de espacialidade interna.

Gráfico 13: Avaliação referente à legenda dos mapas

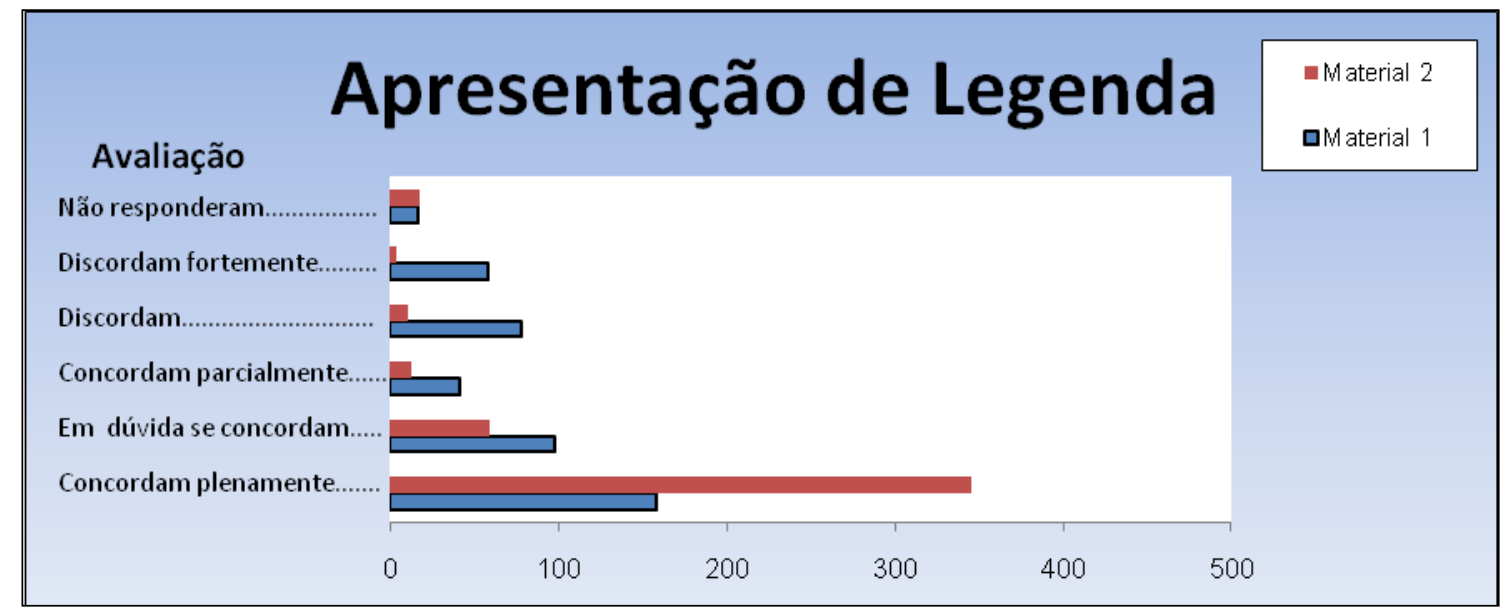

Fonte: organização de ULLER, A. S., 2010.

Ao indagar sobre a legenda foi mais fácil dos entrevistados se posicionarem, visto que apenas o mapa do material 2 tras este atributo, junto à representação gráfica. E além de constatar este diferencial, também foi observado a riqueza de informações obtidas neste elemento do mapa, e a preocupação em atender também o visitante estrangeiro, fazendo a tradução de tais dados para o inglês.

Foi observado pelos entrevistados, que a legenda apresenta símbolos pontuais e lineares bem diferenciados e fácil de compreender, facilitando a leitura e proporcionando a satisfação de se obter informações. 
Os mais ligados a área da geografia, por formação educacional ou pela profissão exercida, ressaltaram ainda a manifestação da legenda as localizações em coordenadas de UTM, que raramente aparece em mapas com a finalidade turística, por serem mais simplistas.

Gráfico 14: Avaliação referente à forma de orientação presente nos mapas

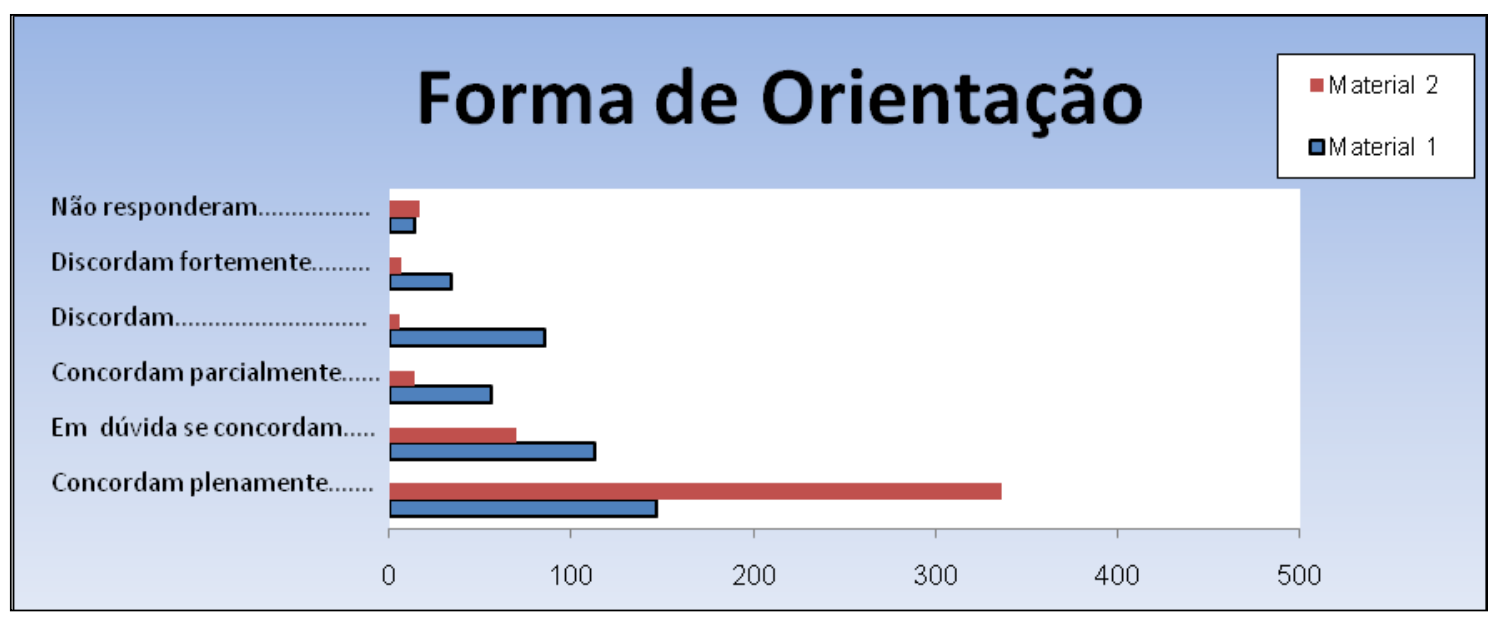

Fonte: organização de ULLER, A. S., 2010.

Referindo-se à orientação, apesar de alguns afirmarem não saber se está corretas, outros entrevistados foram bastante enfáticos em dizer que no material 1, não se tem detalhes para poder se localizar no município e assim poder se deslocar entre um ponto turístico e outro, visto que apresentam apenas poucas vias de acesso, e que para visitantes de fora, nem sabem como chegar à estas ruas denominadas no mapa, pois tal mapa, tem mais uma feição de croqui, mais útil para quem já conhece o local, como os próprios moradores. 


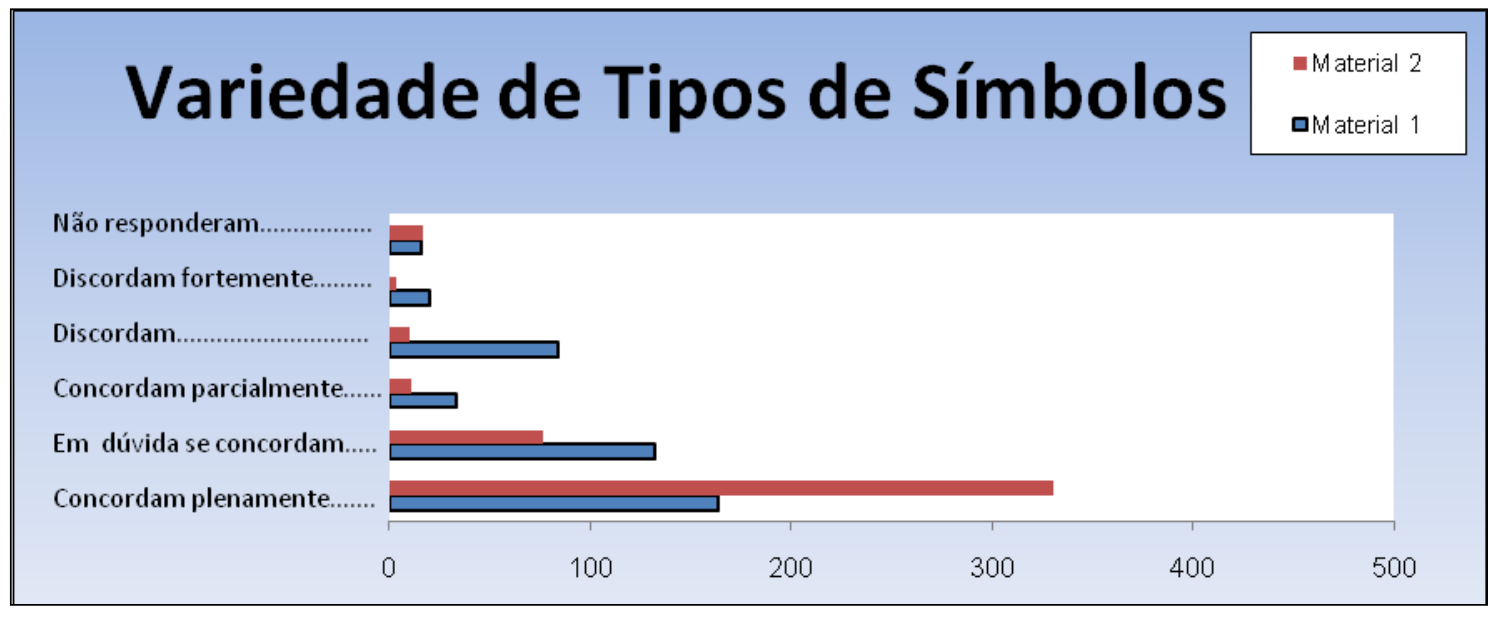

Fonte: organização de ULLER, A. S., 2010.

A variedade de símbolos foi assinalada novamente como mais favorável no mapa do material 2, e embora havendo alguns que alegaram ter muita informação neste mapa, foi bem menos que os depoimentos desfavoráveis quanto à falta de símbolos no mapa do material 1.

Gráfico 16: Avaliação referente à cores empregadas nos mapas

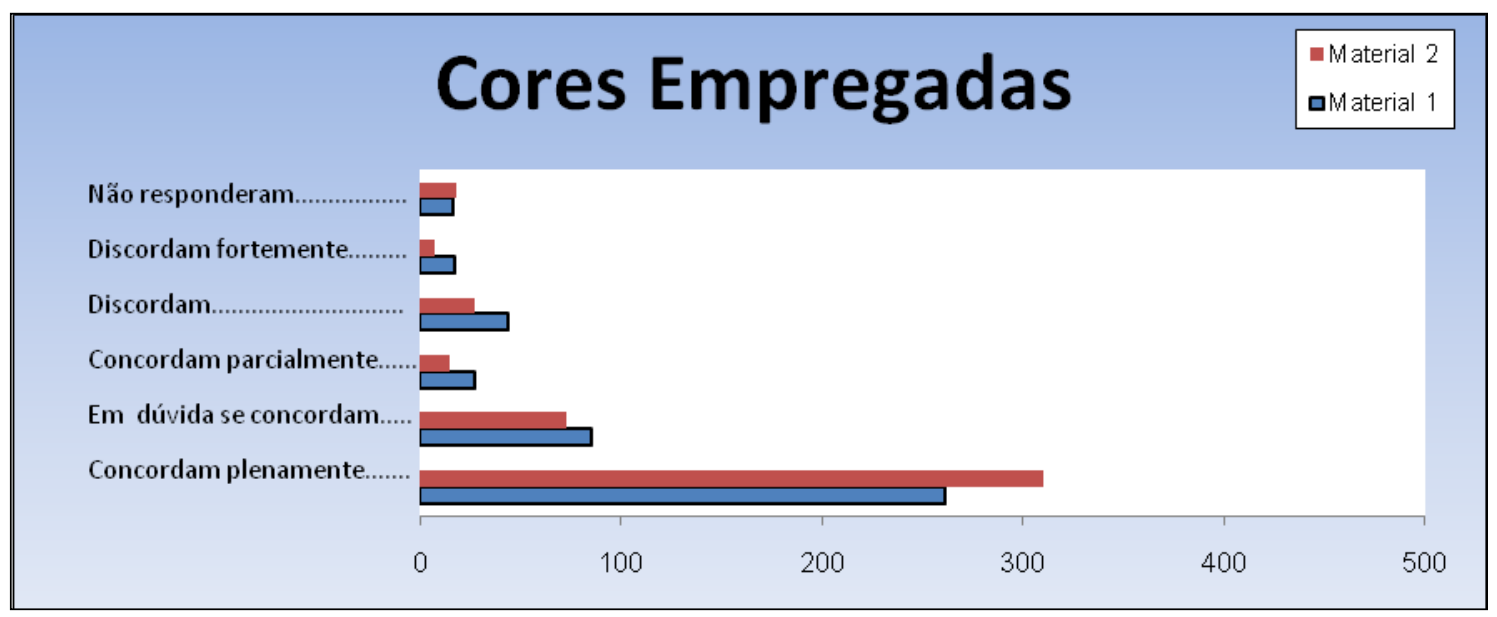

Fonte: organização de ULLER, A. S., 2010. 
Quanto a cor, foi mais fácil de se avaliar, por ser um critério mais compreensível de todos, pois se trata da capacidade de observação dos elementos representados, através de matizes diferenciados. Percebemos que a aceitação foi bastante equilibrada entre os dois mapas, sendo que algumas críticas foram feitas em considerarem que deveriam utilizar ainda tonalidades mais fortes, principalmente, neste caso no mapa 2, que foi impresso em material reciclável que já apresenta uma coloração.

Destacamos aqui, que ambos os mapas referem-se à atributos qualitativos, assim sendo, a cor tinha a função seletiva, e não de ordenação, como ocorre em mapas quantitativos, e que neste caso, haveria a necessidade de um cuidado bastante grande para que realmente se atingisse o efeito esperado de representar ordem de grandeza entre uma tonalidade e outra, conforme vimos anteriormente nos capítulos 1 e 2, especialmente com as considerações de Bertin (1977) e Monmonier (1996).

Gráfico 17: Avaliação referente ao tamanho das informações nos mapas

\section{Tamanho das Informações}

- Material 2

口Material 1

Nåo responderam. Discordam fortemente. Discordam Concordam parcialmente Em dúvida se concordam. Concordam plenamente.

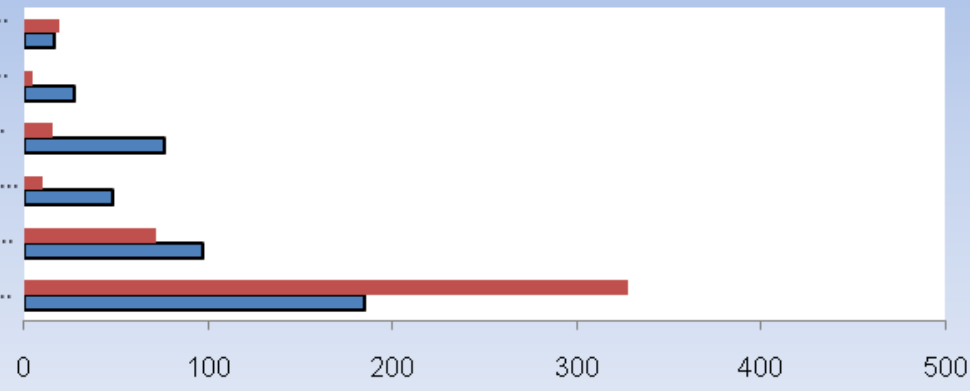

Fonte: organização de ULLER, A. S., 2010. 
O tamanho das informações é outro atributo que nos remete às considerações de Bertin (1977) e Monmonier (1996), quando falam de sobreposições de símbolos como um problema a ser evitado.

$\mathrm{Na}$ avaliação dos entrevistados, é possível observar certa aprovação, referente aos dois mapas, em especial ao mapa do material 2, que consideram ser o mais adequado, embora alguns tenham salientado nas observações que acreditam ser pequeno demais para quem já tem dificuldade de visão. Porém no caso estamos tratando do uso por "homem médio" ${ }^{47}$, e também entendemos que o tamanho dos símbolos deva ser compatível ao tamanho do mapa, conforme instrui os autores pesquisados.

Gráfico 18: Avaliação referente à quantidade de informações nos mapas

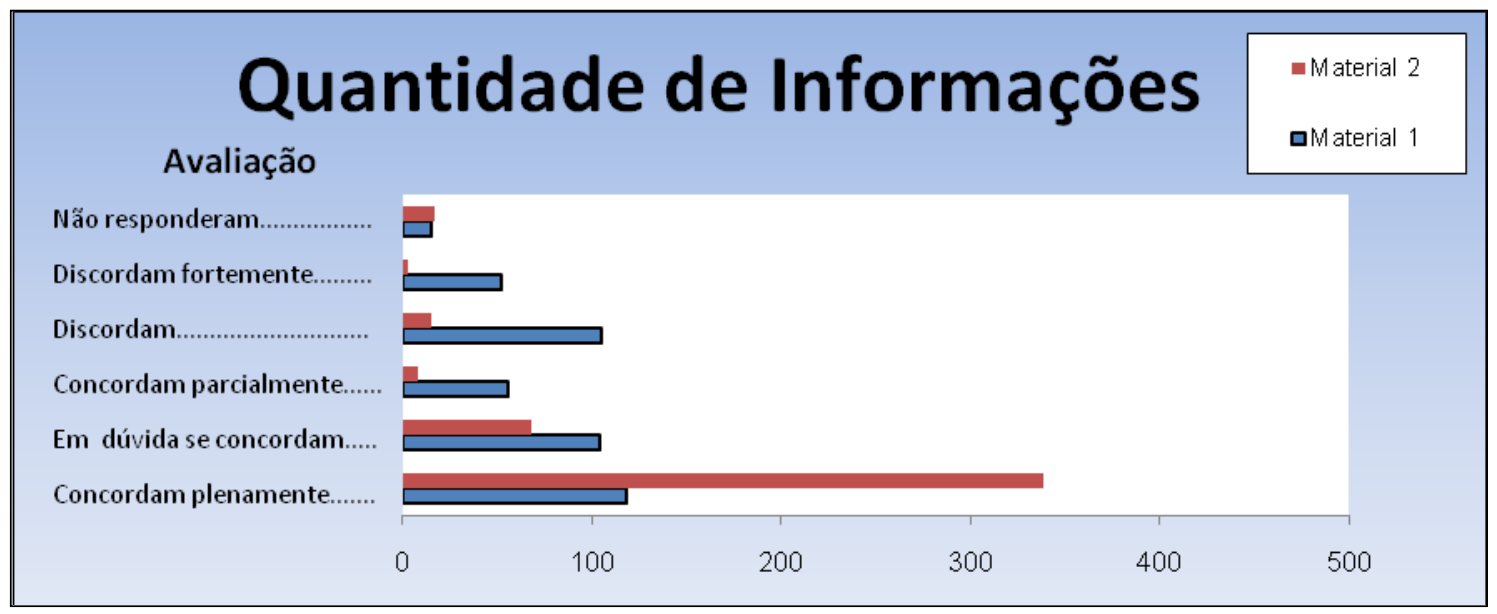

Fonte: organização de ULLER, A. S., 2010.

\footnotetext{
${ }^{47}$ Homem médio refere-se a um padrão de normalidade, ou seja, que não apresente dificuldades ou deficiências congênitas à visão.
} 
Conforme já descrito anteriormente, outra questão bastante enfocada pelos entrevistados foi referente à quantidade de informações. Apesar desta ser para alguns excessiva no mapa do material 2, todos são unânimes em dizer que, o mapa deve atender à finalidade de informar. Isso justifica o descontentamento apontado na quantificação do gráfico quanto ao descontentamento do material 2 , que recebe ainda alguma valoração por apresentar um esboço das localidades turísticas, mas que no entanto, fica devendo muitas outras informações pertinentes, que poderiam ser em grande parte sanadas, só com a obediência aos critérios básicos de representação cartográfica: orientação, escala e legenda.

Gráfico 19: Avaliação referente à síntese de informações nos mapas

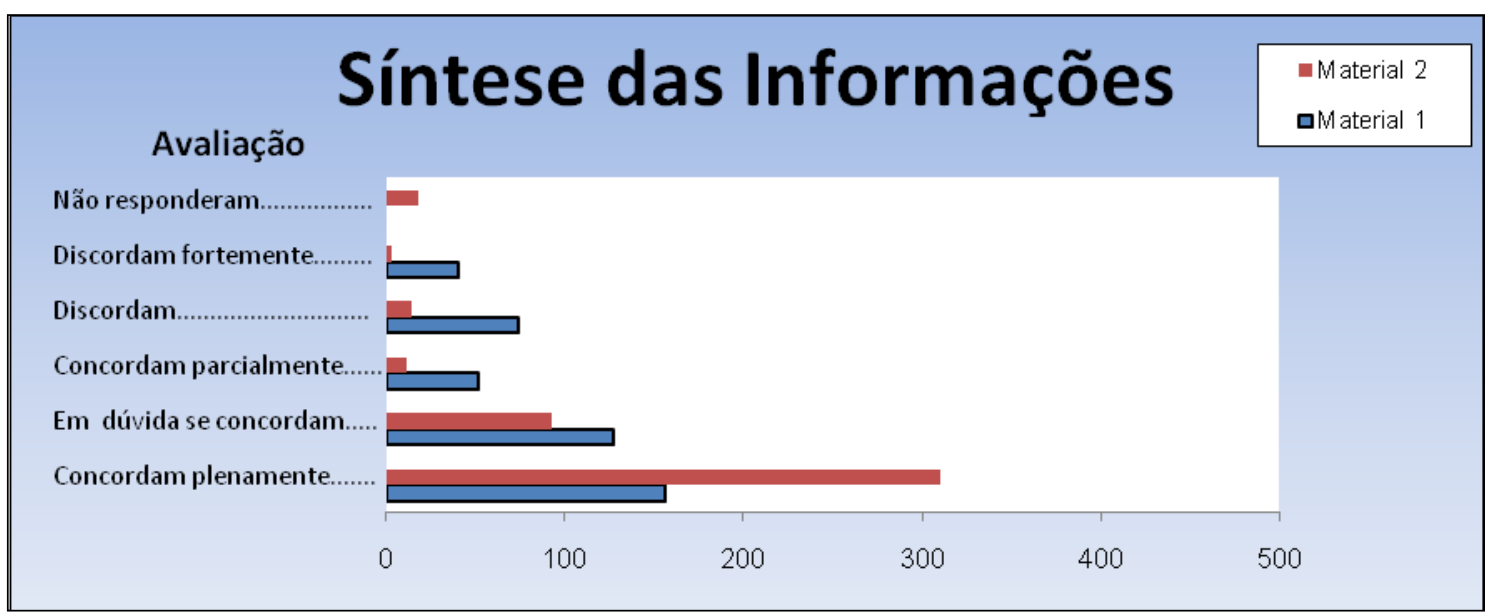

Fonte: organização de ULLER, A. S., 2010.

Também não ficou de fora a observação quanto a capacidade de generalização de informações e síntese, evitando que o mapa apresente uma poluição visual. A respeito dessa questão, o mapa do material dois continua 
saindo melhor apreciado, porém recebe críticas com relação a possibilidade de ter um encarte mais enxuto acompanhando, facilitando com isso a leitura imediata. Diante deste critério, o mapa 1, embora sendo omisso em alguns elementos da cartografia, transmite de modo bastante prático uma visualização do roteiro no mapa, sob espécie de croqui, em que se encontram os atrativos turísticos.

Gráfico 20: Avaliação referente à distribuição espacial dos dados no mapa

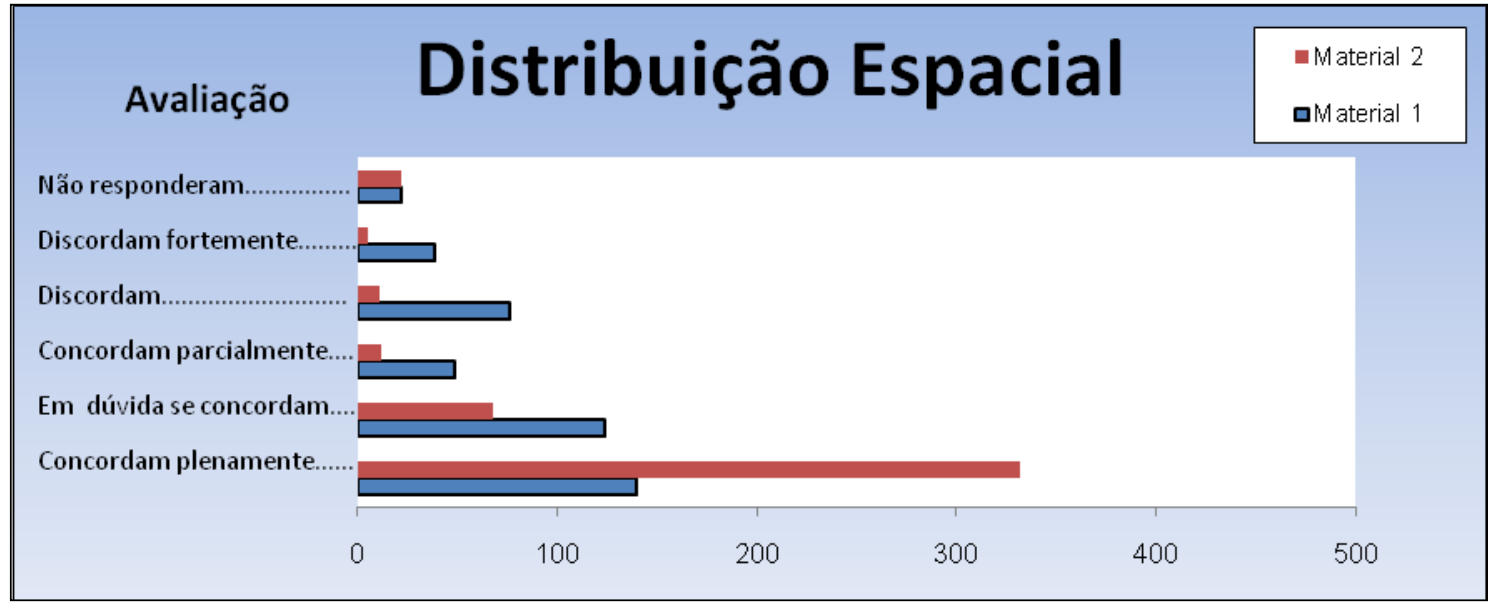

Fonte: organização de ULLER, A. S., 2010.

Neste critério foram avaliados os pontos turísticos em suas localizações, para verificar a coerência. Uma questão de dificuldade para os visitantes que não conheciam a cidade e viam dificuldades em relacionar um mapa ao outro. Porém, ao contrário destes, os moradores puderam tecer esse olhar de modo mais apurado, apontando algumas distorções no material 1. Aqui portanto, observa-se que seguir o rigor cartográfico de escala, acaba por afetar a orientação, e que isto compromete grandiosamente no momento de se localizar, até porque, no mapa 1, 
não se apresentam vários referenciais de localização, e nem mesmo qualquer espécie de legenda.

Gráfico 21: Avaliação referente às informações de melhores vias de acesso

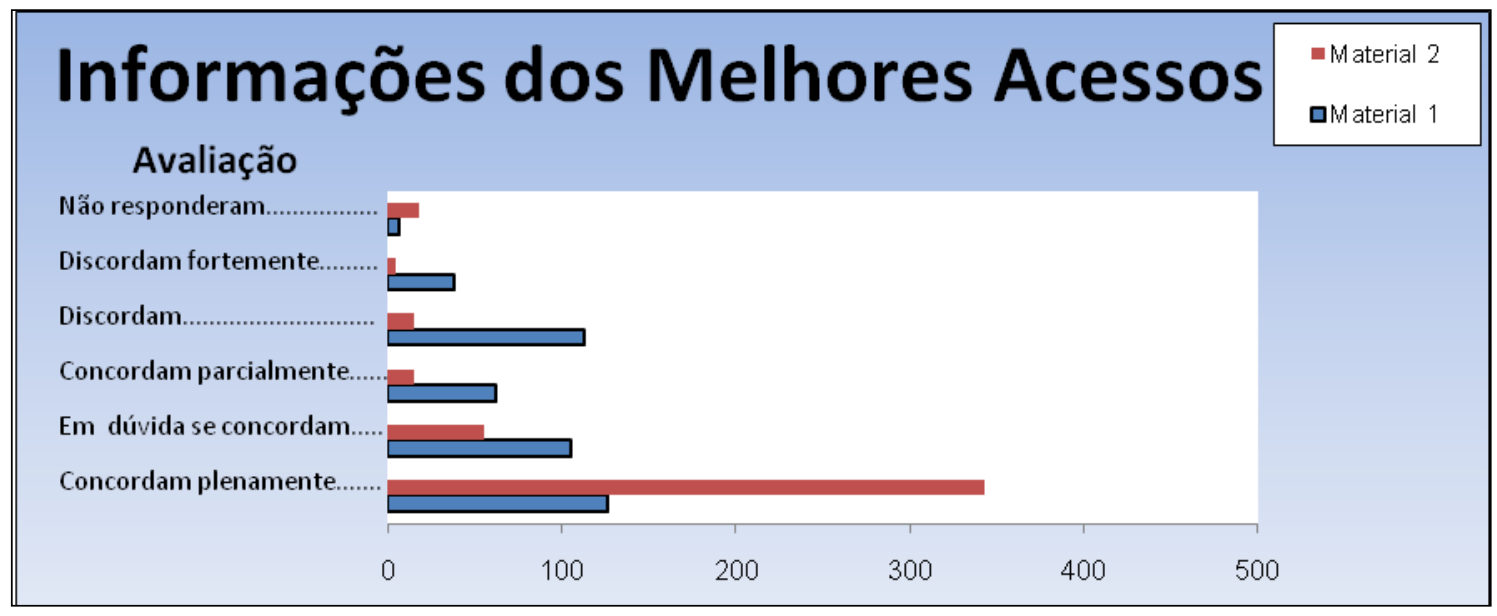

Fonte: organização de ULLER, A. S., 2010.

Além da necessidade de localização, algo de bastante pertinência ao turismo é ter informação para os melhores acessos para o deslocamento, bem como as vias alternativas, para que em caso de uma estar interrompida por algum motivo, já ter em mãos uma opção de escoamento viário.Novamente o mapa 2 tem a preferência por trazer bastante detalhes informativos, e até mesmo especificando o tipo de vias, onde o usuário poderá se deslocar de qualquer localidade em direção ao ponto turístico desejado, encurtando tempo de percurso, através de escolhas de caminhos mais práticos e rápidos. 
Gráfico 22: Avaliação referente à identificação dos lugares no mapa

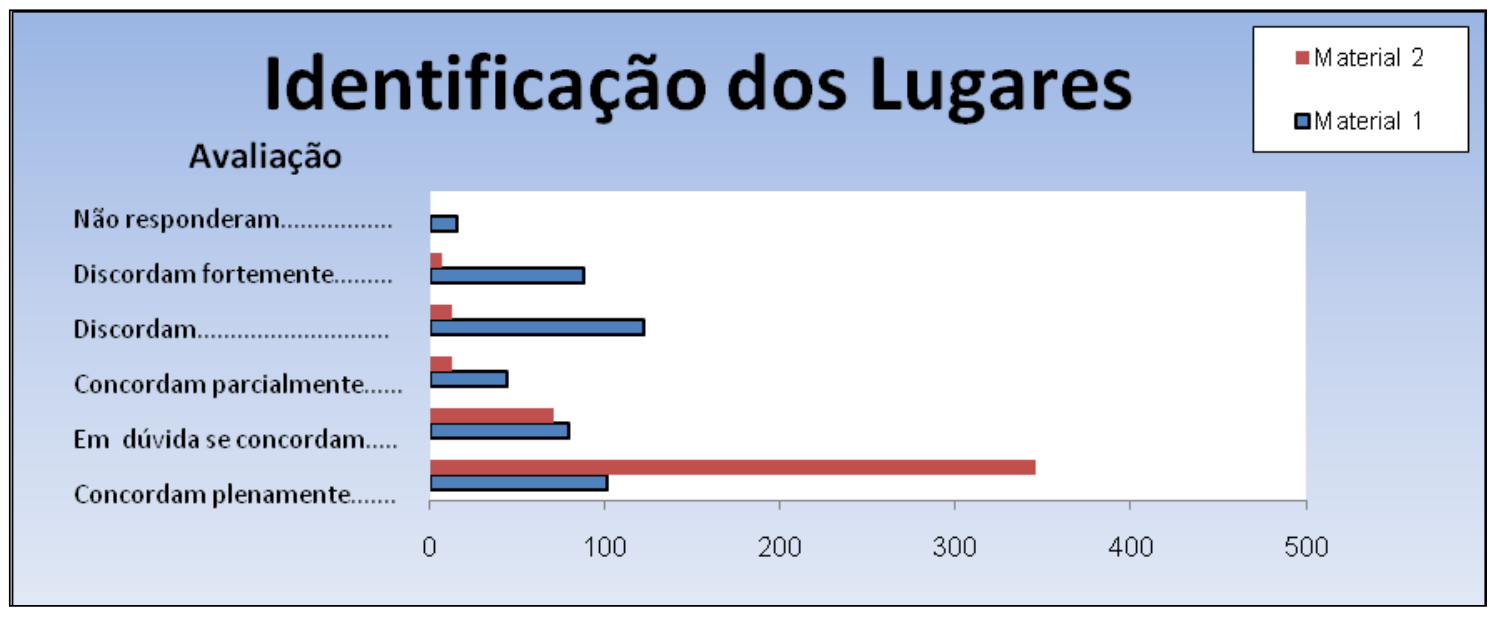

Fonte: organização de ULLER, A. S., 2010.

A identificação dos lugares está associada à simbologia empregada e sua tradução (decodificação) na legenda. Assim, como o mapa do material 1 não possuia legenda, já era presumido que avaliassem melhor o mapa do material 2. No entanto, alguns atribuíram como validade a identificação verbal junto aos símbolos, como ocorre no material 1, que foi menos apreciado.

Neste critério, é bastante relevante as considerações de nosso arcabouço teórico, com relação à Semiologia, e a própria Semântica existente no mapa, que irão favorecer ou não a leitura monossêmica. Para isso, conforme a firma Bertin (1977), Monmonier (1996), Martinelli (1991), e demais autores elencados, é fundamental saber quais são as informações necessárias, e quais atributos melhor a representam, fazendo promover a relação entre SIGNO<>SIGNIFICANTE<>SIGNIFICADO. 
Gráfico 23: Avaliação referente à existência de legenda informando os tipos de turismo na temática do mapa

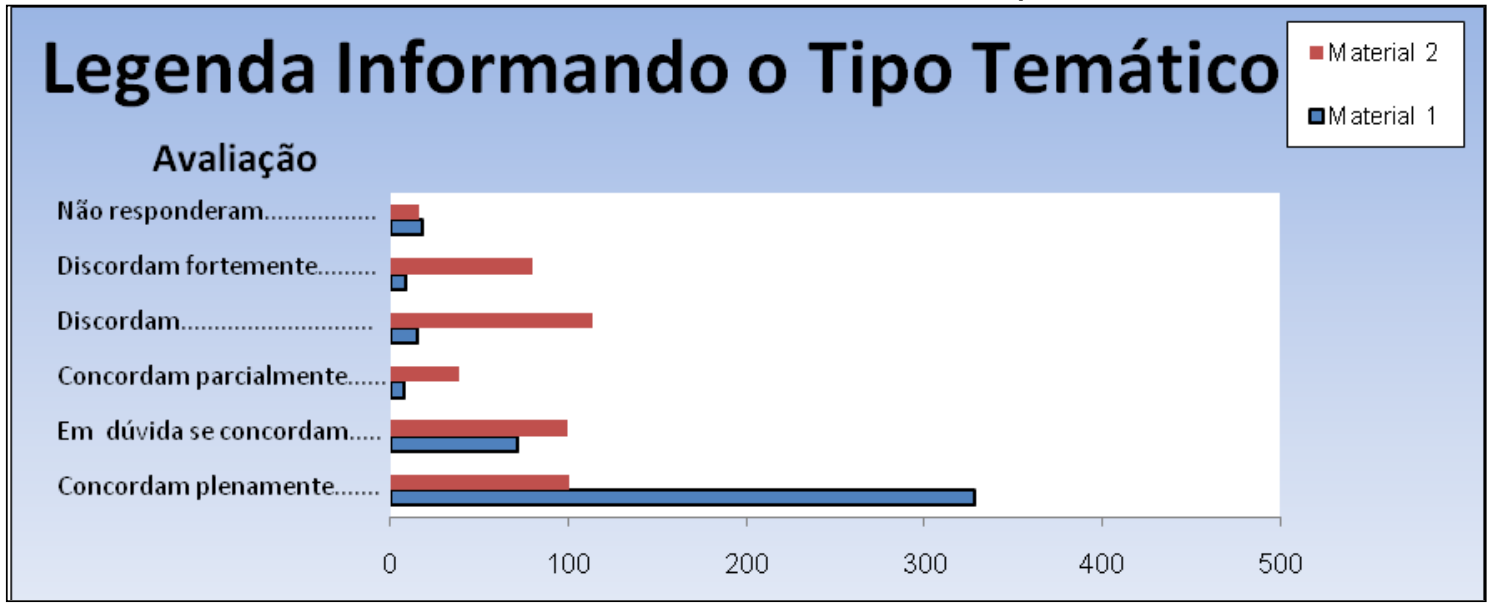

Fonte: organização de ULLER, A. S., 2010.

Os entrevistados consideraram bastante relevante a forma como o mapa 2 atende as expectativas do turista, trazendo até mesmo a classificação temática quanto ao tipo de turismo encontrado em cada um dos pontos, ou seja, se o mesmo era de importância natural ou cultura, se servia para lazer com área de banho e de camping e demais critérios observações.

\subsubsection{Análise Geral}

Guiando-nos por este instrumento de investigação, resultante das entrevistas, comprovamos nossas hipóteses prévias quanto a que tipo de material surte mais efeito ao usuário turista. Os mesmos condicionantes são apontados pelos sujeitos entrevistados que valorizam ambos os materiais, mas percebem a 
facilidade de leitura mediante representação mais clara, a praticidade de manipulação do material menor, embora o outro, por ser dobrável também ser muito aceito.

Valorizam em especial os critérios de localização, atrelados à escala, bem como a disposição de variadas informações que lhe são pertinentes. Neste sentido nos reportamos às colocações de Monmonier quando instrui que "Comparar dois ou mais mapas mostrando a mesma área em escalas substancialmente diferentes é uma boa maneira de apreciar a necessidade de generalização geométrica" (1996).

Quanto às cores, consideram que o mais nítido possível auxilia na distinção das informações, e ainda que se o tamanho de letras e símbolos for maior, sem poluir, atenderá mais facilmente a leitura imediata.

Consideram a importância da síntese como um facilitador na identificação dos atributos, porém dão legitimidade à necessidade de informações claras e precisas, como escala e orientação.

Entendemos com isso que num aspecto geral, os usuários conseguem perceber com clareza a necessidade do mapa, os requisitos indispensáveis, e as problemáticas enfrentadas diante de um mapa que não informa, ou ainda desinforma, como se fosse uma mentira, salientando que isso compromete não só os seus deslocamentos pelo espaço, bem como o próprio interesse em visitar. 


\section{CONSIDERAÇÕES FINAIS}

O trabalho de pesquisa aqui apresentado como tese de doutorado vem de encontro aos nossos interesses em contribuir de forma modesta para com a ciência geográfica, na tentativa de dar um passo à frente sobre a temática um tanto recente e carente de reflexões.

Mais que soluções, receitas ou caminhos, o que foi pretendido era lançar questões de reflexões sobre a cartografia turística, partindo de um recorte explorado em profundidade e analisado sob a ótica da vertente geográfica, buscando um pensar crítico, diferente talvez de outras áreas.

No decorrer de nossa explanação, pudemos estar refletindo sobre as diretrizes traçadas no projeto inicial:

\# Verdade X Mentira no âmbito científico

Ficou claro, principalmente com o respaldo de Monmonier, que nossos documentos cartográficos estão permeados de erros e mentiras que afetam em muito a credibilidade do usuário, quando não causam ainda problemas piores, impedindo-os de se localizar, de obter informações e principalmente até de refletir através deste instrumento de comunicação. Nesse sentido, a ciência é chamada para refletir sobre o seu papel frente a sociedade, no intuito de tomar para si a responsabilidade de dar maior rigor a essa produção, capacitando 
adequadamente os profissionais que se interessam por essa área, e ocupando o lugar que the é devido, na produção de mapas.

Ao mencionarmos a necessidade de posicionamento dos geógrafos frente ao trabalho de produção de mapas, não se trata de uma luta por espaço de trabalho, um corporativismo, mas sim de uma postura ética de quem domina a qualificação para tal tarefa, com um compromisso verdadeiramente social com a profissão.

\section{\# Erro proposital X Incapacidade Técnica}

Não cabe aqui acusar os culpados diante dos problemas, mas admitir que existe tanto erros propositais, com a finalidade de distorcer informações, e manipular opiniões, quanto casos de verdadeira alienação frente a área da Cartografia. E nesse sentido, a incapacidade técnica, geralmente se dá, conforme foi visto, porque com o avanço dos meios informatizados de mapeamento "tornouse fácil para qualquer um criar mapas". Um doce engano que pode causar grandes danos.

Indiferentemente de acabar tendo que vez ou outra cair em "mentira ou erro cartográfico" na prática, o nosso papel enquanto profissionais é buscar fazer o melhor, o mais correto, em prol da ciência e também da sociedade, que precisa deste conhecimento em diferentes instâncias da vida.

Nessa lógica, também o conhecimento das geotecnologias, não pode ser encarado exclusivamente como uma simples busca do domínio de um software, produtor de mapas, mas envolve um engajamento com as discussões éticas profissionais, de modo a aproveitar desse avanço tecnológico em prol de solução 
de problemas práticos com maior agilidade e perfeição. Isso significa valorizar esta contribuição da modernidade capitalista, em prol de atuações de políticas públicas de cunho espaciais, utilizando-se dos recursos e dados que hoje se apresentam em mais fácil acesso, e dando significados aos fenômenos, num raciocínio mais apurado, onde se leve em conta a existência de uma crítica constante.

\section{\# Interesse Mercadológico X Responsabilidade Social do Profissional}

Como foi abordado em nosso trabalho, o setor de marketing, tem se apropriado da produção de mapas enquanto recursos gráficos de propaganda de uma espacialidade, para atender às demandas e interesses do mercado. Em função disso, tecemos uma crítica, respaldada nas bases teóricas de Mark Monmonier, e demais autores consultados, onde se pressupõe que, o profissional que atual na produção de mapas deva ter um vínculo de comprometimento, a ponto de se responsabilizar pela veracidade das informações transmitidas, sem ficar alheio diante da repercussão social de possíveis negligências e imperícias técnicas que se façam presentes no documento gráfico produzido, sabendo que estas podem gerar consequências muito negativas.

Apesar da tradicional conotação positivista atribuída à Cartografia, por ser uma área mais técnica, militamos na linha de outras versões mais dialéticas, defendida por muitos teóricos brasileiros como Girardi (2008), Martinelli (2001), Matias (2001), entre outros, e renomados internacionais como Harley (1989), MacEachren (1994), WOOD e FELS (1992), e é claro, MONMONIER (1996; 2007), a nossa diretriz teórica, que exigem em seus princípios a necessidade de uma crítica desses trabalhos representativos, no âmbito da Cartografia. 
Ao nosso entender, técnica e crítica não podem ser concebidas como polos antagônicos da ciência, mas complementares e facilmente conciliáveis, desde que se haja um profundo conhecimento científico epistemológico e social, que se finda no verdadeiro fazer geográfico, ou porque não dizer, em sua "práxis" legítima.

Cremos que atingimos o nosso objetivo principal de "Analisar a forma de representação cartográfica temática presente nos mapas turísticos destinados aos visitantes no Município de Ponta Grossa - PR" na certeza de que, não fizemos de nossos estudos mera teoria pela teoria, mas tentamos vislumbrar através dessa crítica levantada na pesquisa, possibilidades de melhorias no concreto pensado, que é essa realidade apresentada em nosso recorte espacial, o Município de Ponta Grossa.

Pudemos llustrar os tipos de manifestações simbólicas que se utilizam em um mapa formal, na concepção da cartografia temática quando apontamos no primeiro capítulo uma estruturação teórica que discute alguns princípios da semiologia gráfica de Bertin, sobre os componentes essenciais de um mapa (simbologias e apresentação visual, através das variáveis da retina), salientando que tudo isso envolve sempre um grau de arbitrariedade em sua escolha.

A Identificação das situações em que a linguagem cartográfica pode e/ou não pode direcionar o usuário do mapa às leituras errôneas da realidade foi contemplada com a utilização da referência do livro "How to Lie with Maps", de Mark Monmonier, numa excelente escolha para se discutir sobre diferentes situações de construção de mapas que dão grande margem para a ocorrência de erros, muitas vezes com o intuito de confundir, enganar ou desinformar o leitor.

Os livros deste autor trouxeram-nos inúmeros exemplos, extremamente 
didáticos, de "mentiras com mapas", algumas sutis e outras deslavadas, como afirma o próprio autor, e que vieram de encontro com a nossa realidade no problema tratado.

Refletir sobre a origem (fonte) das produções dos mapas turísticos no Município de Ponta Grossa - Paraná, foi algo que concretizamos no momento inicial de investigação, quando nos deparamos com os materiais existentes e fomos buscar a autoria dos mesmos, sendo que conseguimos identificar somente o autor do mapa que foi considerado mais adequado, até porque, entre as muitas informações que o mapeador não deixou faltar no material, esteve presente, destacado de forma merecida, a fonte de autoria. Com a entrevista pessoal, percebemos a ligação íntima deste que se profissionalizou em turismo, mas que buscou no aperfeiçoamento, a Geografia, e mais particularmente a Cartografia. Daí a capacidade de tecer um olhar mais prudente sobre os requisitos essenciais de um mapa, que fazem parte da demanda de qualquer usuário turista.

As consequências de mapas errôneos ou mal elaborados, também foram percebidas na prática das entrevistas aplicadas em nossa localidade, onde observamos a descredibilidade dos usuários quando se deparam através da análise, que o documento cartográfico, no caso, o mapa, apresenta erros e não atende com isso as suas necessidades.

Nos reportamos com esse resultado, novamente à Monmonier, quando afirma que o propósito de seus escritos tem sido alcançado, pois é justamente 0 de promover um saudável ceticismo sobre mapas, e não apresentar o cinismo ou um tipo de desonestidade deliberada. Assim afirma o autor em seus relatos: 
"...eu quero fazer leitores cientes que mapas, como discursos e pinturas, são criados a partir de um conjuntos de informações e que também estão sujeitos a distorções decorrentes da ignorância, ganância, cegueira ideológica ou malícia. Examinar os usos indevidos dos mapas também fornece uma introdução interessante à natureza de mapas e sua gama de usos adequados". (tradução de Monmonier, 1996)

Da mesma forma, tais provocações, obtidas a partir dos resultados da pesquisa, nos favoreceu por final, enriquecidas por sugestões dos próprios turistas, direcionamentos importantes a serem considerados nas novas produções de mapas turísticos:

Em primeiro lugar, a questão de que, mesmo sendo de interesse do mercado, promover o lugar, se estamos produzindo um mapa com o intuito de informar o turista, devemos assumir a responsabilidade de apresentar uma veracidade dos elementos essenciais, e ainda, se for requerido, por meio de instituições promotoras, o apelo ao uso de elementos pictóricos, antes devemos verificar uma forma de, mesmo no material, sensibilizar as pessoas para esses tipos de truques cartográficos, pois esse deve ser um compromisso ético profissional.

No caso de Ponta Grossa, já se tem um mapa bastante adequado, agora precisa sociabilizar esta produção, valorizando o mesmo com tiragens frequentes, e ainda criando novos mapas temáticos, oriundos deste, para atendimento de finalidades específicas de turismo, numa espécie de coleção de mapas: turismo rural, turismo de aventura, ecoturismo, turismo de lazer e diversões, turismo religioso, entre outros. 
Em segundo lugar, relacionar o profissional geógrafo nesse trabalho do "fazer cartográfico", pois o mesmo está apto a realizar mais facilmente uma leitura crítica das espacialidades concretas e num procedimento técnico das viabilidades de representação. Entendemos que muitos produtores de mapas de outras áreas, mais voltada a publicidade e propaganda, praticamente criam uma ideia de homogeneidade de desejos, padronizando suas formas de manipulação nos mapas turísticos, porém não refletem que os usuários, por não possuírem senso crítico imediato diante daquele material, ficam mais vulneráveis aos apelos das publicidades, e a medida que se defrontam com os problemas de falta de informações, referenciais importantes, ou percebam as inverdades representadas se tornarão céticos.

Estes usuários deixarão de dar credibilidade aos mapas, bem como à estas localidades visitadas, desenvolvendo a comentada "cartofobia", citada por Monmonier, ou até mesmo podendo despertar uma nova patologia, a "turismofobia".

Em terceiro lugar, apesar de direcionarmos neste momento um olhar específico sobre a produção temática de mapas turísticos, não esquecemos das raízes primordiais, da necessidade de uma alfabetização cartográfica adequada nas escolas (conforme nossos enfoques em SIMIELLI em estudos anteriores), e investindo-se melhor na qualificação dos professores (que foi nossa pesquisa de Mestrado).

Resgatamos estas lembranças neste momento de considerações finais para salientar que não perdemos de vista que do outro lado está a necessidade 
de formar um público educado para compreender as representações cartográficas, enquanto instrumentos essenciais de informação.

Precisamos de toda forma, preparar os sujeitos para a cidadania, de modo a serem capazes de fazer uso dos recursos existentes, para o seu autodirecionamento, bem como tendo responsabilidade sobre seus atos profissionais perante a coletividade que faz uso de seus serviços, mesmo que através dos seus produtos gerados. Assim, voltamos a afirmar que não basta investir em tecnologia, nem super valorizar um software em detrimento a outro, ou achar que tecnologia virou uma "religião", passando a "endeusá-la" (conforme afirma Matias), se o sujeito que opera os sistemas é alienado e omisso aos efeitos desse artifício em mãos erradas.

Devemos ainda, antes de tudo, antes de qualquer tomada de decisão prévia, reconhecer que o melhor software, a melhor técnica é aquela que sei trabalhar, e que responde às minhas questões, ao meu problema, em virtude de atender aos anseios sociais. No caso do mapa turístico, não adianta eu poluir um material com artifícios artísticos rebuscados, para convencer o turista a visitar as localidades paradisíacas, criadas em seu imaginário, se os mesmos não obterem desse instrumento de informação, os subsídios para chegar à estes pontos.

Pretendemos diante destas considerações, como finalização deste trabalho, satisfazer as exigências estabelecidas para esta pós-graduação em nível de doutoramento, e nos sentirmos realizados temporariamente, por termos concretizado mais uma etapa em nossa caminhada de pesquisa e produção escrita, com uma pequena contribuição ao conhecimento geográfico no campo da Cartografia, certos de que nossos estudos não param aqui, pois a trajetória de um 
professor-pesquisador é um constante desbravar da ciência, rumo a novos conhecimentos.

Cremos que a tese é um esforço no sentido de expandir uma teoria, que não é nova em sua totalidade, mas que traz um novo foco de observação e um novo pensar sobre um objeto de pesquisa, com o suporte epistemológico e teórico-metodológico daqueles que estão a frente de nós, numa trajetória de pensar a ciência a muito mais tempo; e que de qualquer forma isso é um grão de areia no mundo de contribuições que carece o meio científico, mas é a satisfação para nós de um dever cumprido para o momento que cabia exclusivamente à nossa responsabilidade profissional. 


\section{REFERÊNCIAS BIBLIOGRÁFICAS ${ }^{48}$}

\section{CITADAS:}

BARBOSA, Ycarim Melgaço - A Publicidade no Turismo: uma Abordagem Crítica. In: BAHL, Miguel. Turismo: enfoques teóricos e práticos. São Paulo: Roca, 2003.

BERTIN, Jacques. Sémiologie Graphique: Les Diagrames, Les Réseaux, Les Cartes. Paris: Mountoun e Gauuthier - Villars, 1967.

L'Information. France: Flammarion, 1977.

- La Graphique et Le Traitement Graphique de - "Um Novo Olhar Sobre a Cartografia". In: Revista

Seleção de Textos: Cartografia Temática. São Paulo: AGB, 1988.

BLACK, Jeremy. Mapas e História: Construindo Histórias do Passado. Tradução Cleide Rapucci. Bauru-SP: Edusc, 2005

CERVI, Emerson Urizzi. Métodos Quantitativos Aplicados às Ciências Sociais. Curitiba: Ministério da Educação e do Desporto/Universidade Federal do Paraná, 2009.

ELLIOT, James. THE CITY IN MAPS: URBAN MAPPING TO 1900. London: The British Library Board, 1987.

ESTADO DO PARANÁ. Mapa das Rotas Turísticas de Curitiba. Curitiba: Secretaria dos Transportes, s/d.

e Meio Ambiente/IAP, s/d Mapa Turístico da Ilha do Mel. Secretaria de Turismo Instituto Ambiental do Paraná

FENNELL, David A. Ecoturismo. (tradução de Inês Lohbauer). São Paulo: Contexto, 2002.

GIRARDI, Eduardo Paulon. Proposição teórico-metodológica de uma Cartografia Geográfica Crítica e sua Aplicação no desenvolvimento do Atlas da questão

\footnotetext{
${ }^{48}$ De acordo com a Associação Brasileira de Normas Técnicas. NBR 6023.
} 
agrária brasileira. In: Tese de Doutorado em Geografia. Presidente Prudente: UNESP, 2008

GIRARDI, Gisele . A Cartografia e os Mitos - Ensaios de Leituras de Mapas. In: Dissertação de Mestrado em Geografia. São Paulo: FFLCH, 1997.

- Cartografia Geográfica: considerações críticas e proposta para ressignificação de práticas cartográficasna formação deo profissional em Geografia. In: Tese de Doutorado em Geografia. São Paulo: FFLCH, 2003.

HARLEY, J. B. Deconstructing the map. Cartographica, 1989.

JOLY, Fernand. A Cartografia. Tradução de Tânia Pellegrini. Campinas - SP: Papirus, 1990.

KOEMAN, Cornelis. O princípio da comunicação da cartografia. In: GEOCARTOGRAFIA. São Paulo: Gecart/Departamento de Geografia USP. Vol 5. 1995. p.03-11.

KOLACNY, A. Informação cartográfica: conceitos e termos fundamentais na cartografia moderna. In: São Paulo: Gecart/Departamento de Geografia USP. Vol 2. 1995. p.03-11.

LACOSTE, Yves. A Geografia: Isso Serve em Primeiro Lugar para Fazer a Guerra. Campinas: Papirus, 1988.

LAXTON, Paul. J.B. HARLEY - The Nature of Maps. Essays in the History of Cartography. Baltimore and London: The Johns Hopkins University Press, 2001.

MAC EACHREN, Alan M. Some Truth With Maps: A Primer on Symbolization an design. Department of Geography The Pennsylvania State University University Park, PA 16802. Washington: Copyright by the Association of American Geographers $1710,16^{\text {th }}$ street, 1994.

MARTINELLI, Marcello. Curso de Cartografia Temática. São Paulo: Contexto, 1991.

Cartografia do Turismo. Que Cartografia é essa? In:

LEMOS, A. I. G. (org.) . Turismo: impactos socioambientais. São Paulo: Editora Hucitec, 1996. P. 296-302.

Paulo: Ed. Moderna, 1998.

Gráficos e Mapas: construa-os você mesmo. São 
Cartografia do Turismo e Imaginário. In: RODRIGUES, A B. (org.). Turismo rural: práticas e perspectivas. São Paulo: Contexto, 2001.

Paulo: Contexto, 2003. . Mapas da Geografia e Cartografia Temática. São

MATIAS, Lindon Ferreira. Sistema de Informações Geográficas (SIG): teoria e método para representação do espaço geográfico. In: Tese de Doutorado. São Paulo: FFLCH, 2001.

MONMONIER, Mark. Computer-Assisted Cartography: Principles and Prospects. Syracuse University Department of Geography, 1982.

. How to Lie with Maps. $-2^{\text {nd }}$ ed. Chicago and London: The University of Chicago Press, 1991; 1996.

. Spying with maps: surveillance technologies and the future of privacy. Chicago and London: The University of Chicago Press, 2002.

From Squaw Tit to Whorehouse Meadow: how maps name, claim, and inflame. Chicago and London: The University Chicago Press, 2007.

OLIVEIRA, Marco Aurélio Alves de. Cartografia e Turismo: O Mapa na Expressão do Espaço Turístico. In: Dissertação de Mestrado em Geografia. São Paulo: FFLCH, 2002.

PEREIRA, Bruno Castellari; BORGES, Marta Poggi e. Turismo de Negócios: uma análise do setor em Piracicaba/SP. In: Caderno Virtual de Turismo. Rio de Janeiro, v. 6, n.ㅇ 4, 2006.

PREFEITURA MUNICIPAL DE CASTRO. Mapas Turístico de Castro. Castro: Conselho Municipal de Turismo - Castrotur, s/d.

PREFEITURA MUNICIPAL DE CURITIBA. Mapa Turístico de Curitiba. Curitiba - PR. Secretaria de Turismo. 2006.

PREFEITURA MUNICIPAL DE FLORIANÓPOLIS . Mapa Turístico de Florianópolis. Prefeitura Municipal de Florianópolis - SC, s/d.

PREFEITURA MUNICIPAL DE MARINGÁ . Mapa Turístico de Maringá. Maringá - PR: Secretaria Municipal de Turismo. 2009

PREFEITURA MUNICIPAL DE PARANAGUÁ. Mapa Turístico de Paranaguá. Paranaguá. Secretaria Municipal de Turismo. s/d. 
PREFEITURA MUNICIPAL DE PONTA GROSSA - Mapa Turístico de Ponta Grossa. Ponta Grossa: Secretaria Municipal de Indústria, Comércio e Turismo. 2000; 2007.

PREFEITURA MUNICIPAL DO RIO GRANDE. Mapa Turístico do Município de Rio Grande. Rio Grande - RS: Secretaria Municipal de Turismo Esporte e Lazer,s/d.

QUEIROZ, Odélia Teles (org.). Turismo e Ambiente: temas emergentes. Campinas - SP: Editora Alínea, 2006.

QUINTA DA ESTÂNCIA. Folder Turístico Rural. Viamão - RS: Quinta da Estância, s/d.

RAMOS, Christhiane da Silva. Visualização Cartográfica e Cartografia Multimídia. Conceitos e Tecnologias. São Paulo: Editora Unesp, 2005.

REALE, Giovanni \& ANTISERI, Dario. Historia da Filosofia - VOLUMES I, II, e III. Antiguidade e Idade Média, do Humanismo a Kant, do Romanismo até nossos dias. São Paulo: Paulus, 1990.

REPÚBLICA DA ARGENTINA. Mapa Tuístico de Las Misiones. Gobierno de La Província de Misiones.s/d

RICHARDSON, Roberto Jarry (et al.). Pesquisa Social: métodos e técnicas. São Paulo: Atlas, 1999.

RODRIGUES, Adyr Balastreri. Turismo e Espaço. Rumo a um conhecimento transdisciplinar. São Paulo: Editora Hucitec, 1997.

SANTAELLA, Lúcia. O que é Semiótica. São Paulo: Brasiliense, 2006.

SANTIL, Fernando Luiz de Paula; QUEIROZ, Deise Regina Elias \& FREIRE, Cipriano de Azevedo. Elaboração do Mapa Turístico da Universidade Estadual de Maringá com uso do Aplicativo AUTOCAD R14. IN: Boletim de Geografia Vol. 2. Ano 20. Maringá: UEM/Departamento de Geografia, 2002.

SANTOS, Milton. A Natureza do Espaço: Técnica e Tempo, Razão e Emoção. São Paulo: EDUSP, 2006.

SANTOS, Roberto Elísio. As Teorias da Comunicação. São Paulo: Paulinas, 2003.

SECRETARIA DE ESTADO DO TURISMO DO PARANÁ. Estatísticas do Turismo no Paraná. Curitiba, 2007. 
SIMIELLI, M. Elena. O Mapa Como Meio de Comunicação Cartográfica Implicações no Ensino de Geografia do 1‥ Grau. In: Tese de Doutorado. São Paulo: FFLCH-USP, 1986.

SLOCUM, Terry A. (et al.). Thematic Cartography and geovisualization. United States of America: Pearson Prentice Hall, 2009.

SOUZA; CORREA. Turismo: conceitos, definições e siglas. 2000.

TEIXEIRA, Amandio L. A.; CHRISTOFOLETTI, Antonio. Sistema de Informação Geográfica. (Dicionário llustrado). São Paulo: Editora Hucitec, 1997.

ULLER, Adriana S.; CARBONAR, Maria Aparecida; ULLER, Waldir - Preservação do Patrimônio Local: Uma Questão para a Educação Mundial? Retratando nossa Realidade em Ponta Grossa. Apucarana: Diocesana 2001.

UNIVERSIDADE DE SÃO PAULO. Sistema Integrado de Bibliotecas. Diretrizes para apresentação de dissertações e teses da USP: documento eletrônico e impresso - Parte I (ABNT). São Paulo, 2009.

VARGAS, Héctor Mendoza; GARCIA, João Carlos. A História da Cartografia nos Países lbero-Americanos.IN: TERRA BRASILIS - Cartografias iberoamericanas. Rio de Janeiro: Revista de História do Pensamento Geográfico do Brasil, 2005-2006-2007.

VIEIRA NETO, Paulo. Estatística Descritiva: Conceitos Básicos. In: Apostila de Curso de Estatística. São Paulo: USP, 2004.

WOOD, Denis with FELS, John. The Power of Maps. New York: The Guilford Press, 1992.

WOODWARD, David e LEWIS, G. A História da Cartografia, Volume 2, Livro 3: Cartografia na Tradicional Africano, Americano, Ártico, Austrália, Pacífico e Sociedades. Universidade de Chicago Press, 1998. , 660 páginas. In: http://66.102.1.113/translate c?hl=pt.R\&sl=en\&u=http://www.press.uchicago.edu/ Misc/Chicago/907287.

\section{SITES ELETRÔNICOS:}

http://www.markmonmonier.com/events.htm (homepage do autor)

http://www.pead.faced.ufrgs.br/sites/publico/.../e2a6b 1.htm (acessado em 27 de agosto de 2010)

http://www.quinta@quintadaestância.com.br (acessada em 20 de abril de 2008) 


\section{CONSULTADAS}

AKERMAN, James R. American Promotional Road Mapping in the Twentieth Century. In: Cartography and Geography Information Science. Vol. 29, $n^{\circ} 3, p$. 175-192. July 2002. (http://books.google.com.br/)

ALMEIDA, Rosângela Doin (org.). Cartografia Escolar. São Paulo: Contexto, 2007.

ALMEIDA, Rosângela Doin; PASSINI, Elza Y. O Espaço Geográfico : Ensino e Representação. São Paulo: Contexto, 1989.

ANDRADE, Manuel Correia. Caminhos e Descaminhos da Geografia. Campinas - SP: Papirus, 1989.

ANTONELLO, Ideni Terezinha; MOURA, Jeani Delgado Paschoal; TSUKAMOTO, Ruth Youko (orgs.). Múltiplas Geografias: Ensino-Pesquisa e Reflexão. Londrina: edições Humanidades, 2005.

AUMONT, Jacques. A Imagem. (tradução de Estela dos Santos Abreu e Claudio C. Santoro). Campinas - SP: Papirus, 1983.

BAHL, Miguel. Conteúdos Culturais e Naturais em Roteiros Turísticos versus Artificialismo Induzido. In: Turismo: enfoques teóricos e práticos. São Paulo: Roca, 2003.

BIGNAMI, Rosana. A Imagem do Brasil no Turismo: Construção, Desafios e Vantagens Competitivas. São Paulo: Aleph, 2005.

BLASCHKE, Thomas; KUX, Herman. Sensoriamento Remoto e SIG avançados: novos sistemas sensores: métodos inovadores. São Paulo: Oficina de Textos, 2007.

CANDAU, Vera Maria. Universidade e Formacão de Professores: Que Rumos Tomar? In: Magistério: Construcão Cotidiana. Petrópolis: Vozes, 1997.

CASTELLAR, Sônia (org.). Educação Cartográfica: Teorias e Práticas Docentes. São Paulo: Contexto, 2006.

CASTROGIOVANNI, Antonio Carlos (org, et al.). Geografia em Sala de Aula: práticas e reflexões. Porto Alegre: Ed UFRGS e AGB local, 2001.

CREWE, Sabrina. Maps and Globes. Step-by-step Geography. London: Children's Press Reinforced Binding, 1997. 
DEETZ, Charles H. Cartography. Honolulu, Hawaii: University Press of the Pacific, 2005.

DOWLING, Ross K.; NEWSOME, David. Geotourism. Oxford: Elsevier ButterWorth Heinemann, 2006.

DUARTE, Paulo Araújo. Fundamentos de Cartografia. Florianópolis: Editora da UFSC, 2002.

DUQUE, Renato Câmara; MENDES, Catarina Lutero. O Planejamento Turístico e a Cartografia. Campinas-SP: Editora Alínea, 2006.

FERREIRA, João Carlos Vicente. O Paraná e seus municípios. Maringá: Memória Brasileira, 1996.

FIORI, Sérgio Ricardo. Mapas Turísticos: O desafio do Uso da Arte na Era Digital. In: Dissertação de Mestrado em Geografia. São Paulo: FFLCH, 2003.

Mapas para o Turismo e a Interatividade. Proprosta Teórica e Prática. In: Tese de Doutorado em Geografia. São Paulo: FFLCH, 2007

FRANCASTEL, Pierre. A Realidade Figurativa. Elementos Estruturais de Sociologia da Arte. (tradução de Mary Amazonas Leite de Barros). São Paulo: Ed. Da Universidade de São Paulo, 1973.

FREIRE, Cristina. Além dos Mapas: os monumentos no imaginário urbano contemporâneo. São Paulo: SESC: Annablume, 1997.

FREMLIN, Gerald; ROBINSON, Arthur H. Maps as mediated seeing. Fundamentals of Cartography. Canada and United Kingdom: Trafford Publishing, 2005.

GASTAL, Susana. Alegorias Urbanas . O Passado como subterfúgio. Campinas, SP: Papirus, 2006.

GIRARDI, Gisele . Do Outro Lado do Mapa - Eixos de pesquisa em Comunicação Cartográfica aplicados à Cartografia Temática. In: Trabalho de Conclusão de Curso de Graduação em Geografia. São Paulo: FFLCH, 1993.

GOMES, Maria do Carmo A. Velhos Mapas, Novas Leituras: Revisitando a História da Cartografia. In: Revista Espaço e Tempo № 16. São Paulo: GEOUSP, 2004. PP 67-79. 
JOHNSTON, R.J. Geografia e Geógrafos - A Geografia Humana angloamericana desde 1945. Tradução de Oswaldo Bueno Amorim Filho. São Paulo: FIFEL,1986.

JOLY, Martine. Introdução à Análise da Imagem. (tradução de Marina Appenzeller) Campinas-SP: Papirus, 1996.

LINDBERG, Kreg; HAWKINS, Donald E. Ecoturismo: Um Guia para Planejamento e Gestão. (tradução de Leila Cristina de M. Darin)

LOIS, Carla. Mare Occidentale: La Aventura de Imaginar El Atlântico em Los Mapas Del Siglo XVI. IN: TERRA BRASILIS - Cartografias ibero-americanas. Rio de Janeiro: Revista de História do Pensamento Geográfico do Brasil, 20052006-2007.

MARTIN-BARBERO, Jesús. Ofício de Cartógrafo: Travesías latinoamericanas de La comunicación em La cultura. México/Chile: Fondo de Cultura Económica, 2002.

MENEZES, Paulo Marcio Leal de; FERNANDES, Manoel do Couto. Cartografia turística: novos conceitos e antigas concepções ou antigos conceitos e novas concepções. (artigo). Rio de Janeiro: UFRJ (GeoCart) s/d.

MOESCH, Marutschka Martini. A produção do saber turístico. São Paulo: Contexto, 2000.

MORAES, Antonio Carlos Robert. Ideologias Geográficas. Espaço Cultura e Política no Brasil. São Paulo: Ed. Annablue, 2005.

MOREIRA, Rui. O que é Geografia. São Paulo: Brasiliense, 2007.

NIETZSCHE, Friedrich Wilhelm. Org. Sobre Verdade e Mentira. (Trad. BARROS, Fernando de Moraes). São Paulo: Hedra, 2008.

OLIVEIRA, L. Estudo Metodológico e Cognitivo do Mapa. In: Tese de Livre Docência. São Paulo: IG-USP, 1978.

PAGANELLI, T. Y. A Noção de Espaço e Tempo. In: Revista Orientação № 6. São Paulo: IG-USP, Nov. 1985. PERRENOUD, Philippe - Práticas Pedagógicas, Profissão Docente e Formação. Lisboa, Don Quixote, 1993.

PENA, Luiz Carlos Spiller. Turismo: Ação e Reação. In: BAHL, Miguel. Turismo: enfoques teóricos e práticos. São Paulo: Roca, 2003.

RIQUE, Lenyra. Do senso comum à geografia científica. São Paulo: Contexto, 2004. 
ROSCOCHE, Luis Fernando; SAHR, Cecilian Luiza Löwen. Integração Regional: Potencialidades para o Turismo nos Campos Gerais do Paraná. IN: Boletim de Geografia Vol. 1. Ano 21. Maringá: UEM/Departamento de Geografia, 2003.

SAKITAMI, lara. Geografia e Cartografia do Turismo. In: Dissertação de Mestrado em Geografia. São Paulo: FFLCH, 2006.

SANTOS, Douglas. A reinvenção do Espaço. Diálogos em torno da construção do significado de uma categoria. São Paulo: Ed. UNESP, 2002.

SIMIELLI, M. Elena. - Primeiros Mapas - Como Entender e Construir. São Paulo: Ed. Ática, 1994.

SILVA, Ardemiro de Barros. Sistema de Informações Geo-Referenciadas. Conceitos e Fundamentos. Campinas - SP: Editora Unicamp, 2003.

SOUZA, Alvaro José de. Geografia Linguística. Dominação e Liberdade. São Paulo: Contexto, 1990.

SUERTEGARAY, D. M. A. Pensando o Espaço. In: O Ensino da Geografia. ljuí: FUDENE/UNIJUÍ, 1986.

THOMAZI, Silvia M. Cluster do Turismo. Introdução ao Estudo de Arranjo Produtivo Local. São Paulo: Editora Aleph, 2006.

TORRES, R. M. Formación docente: clave de la reforma educativa. In: UNESCO: Nuevas formas de aprender y enseñar. Santiago, Chile: UNESCO-SANTIAGO, 1996.

ULLER, Adriana S. - "Educação Cartográfica na Geografia do Ensino Básico do $1^{\circ} \mathrm{Grau}$ " Monografia de Especialização em Ensino de Geografia. Londrina: UEL, 1995.

- "Formação e Prática dos Professores de Geografia Egressos da UEPG - Problemas e Perspectivas". Mestrado em Educação. Ponta Grossa: UEPG, 2002.

ZUQUETTE, Lázaro V.; GANDOLFI, Nilson. Cartografia Geotécnica. São Paulo: Oficina de Textos, 2004. 


\section{ANEXO 1: Dados pesquisados sobre perfil dos visitantes no Parque Estadual de Vila Velha no ano de 2009.}

Quadro A.1. Total de Visitantes e Distribuição por Gênero

\begin{tabular}{|l|l|l|l|}
\hline Mês & Total de Visitantes & Homens & Mulheres \\
\hline Janeiro & 4287 & 2022 & 2265 \\
\hline Fevereiro & 4074 & 1921 & 2153 \\
\hline Março & 2282 & 1119 & 1163 \\
\hline Abril & 3816 & 1821 & 1995 \\
\hline Maio & 3064 & 1474 & 1590 \\
\hline Junho & 2687 & 1260 & 1427 \\
\hline Julho & 3352 & 1629 & 1723 \\
\hline Agosto & 2417 & 1186 & 1231 \\
\hline Setembro & 1848 & 916 & 932 \\
\hline Outubro & 2580 & 1251 & 1329 \\
\hline Novembro & 4496 & 2141 & 2355 \\
\hline Dezembro & 5527 & 2765 & 2762 \\
\hline TOTAL & 40430 & 19505 & 20925 \\
\hline
\end{tabular}

Quadro A.2: Meios de Condução Utilizados para Chegarem à Visitação

\begin{tabular}{|c|c|c|c|c|c|c|c|c|c|c|c|c|c|}
\hline $\begin{array}{l}\text { Meio de } \\
\text { Acesso }\end{array}$ & 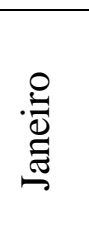 & 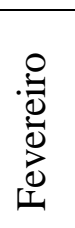 & 递 & 疍 & 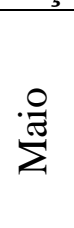 & 号 & $\stackrel{̊}{\Xi}$ & $\begin{array}{l}0 \\
\stackrel{0}{0} \\
8 \\
80 \\
\&\end{array}$ & 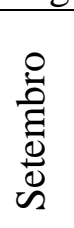 & 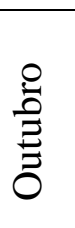 & 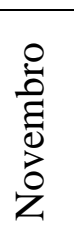 & 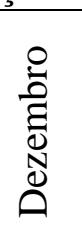 & 空 \\
\hline Carro & 3937 & 3468 & 1685 & 3118 & 1879 & 1556 & 2875 & 2163 & 1394 & 1325 & 1606 & 4062 & 29068 \\
\hline Moto & 0 & 3 & 0 & 17 & 0 & 5 & 34 & 47 & 31 & 23 & 532 & 43 & 735 \\
\hline Van & 40 & 121 & 44 & 164 & 112 & 69 & 74 & 59 & 36 & 44 & 106 & 130 & 999 \\
\hline $\begin{array}{l}\text { Ônibus de } \\
\text { Excursão }\end{array}$ & 310 & 477 & 438 & 220 & 737 & 704 & 295 & 79 & 235 & 868 & 1765 & 265 & 6393 \\
\hline $\begin{array}{l}\text { Ônibus } \\
\text { Escolar }\end{array}$ & 0 & 0 & 108 & 292 & 336 & 352 & 28 & 35 & 0 & 174 & 367 & 1082 & 2774 \\
\hline $\begin{array}{l}\text { Ônibus de } \\
\text { Linha }\end{array}$ & 0 & 5 & 7 & 5 & 0 & 0 & 46 & 27 & 21 & 39 & 15 & 45 & 210 \\
\hline Bicicleta & 0 & 0 & 0 & 0 & 0 & 1 & 0 & 5 & 0 & 0 & 0 & 0 & 6 \\
\hline A pé & 0 & 0 & 0 & 0 & 0 & 0 & 0 & 0 & 0 & 0 & 0 & 8 & 8 \\
\hline Outro & 0 & 0 & 0 & 0 & 0 & 0 & 0 & 2 & 1 & 0 & 0 & 3 & 6 \\
\hline
\end{tabular}


Quadro A.3: Faixa Etária dos Visitantes

\begin{tabular}{|c|c|c|c|c|c|c|c|c|c|c|c|c|c|}
\hline $\begin{array}{l}\text { Faixa } \\
\text { Etária }\end{array}$ & $\begin{array}{l}\stackrel{\circ}{\mathscr{\Xi}} \\
\stackrel{\Xi}{\Xi}\end{array}$ & 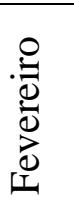 & 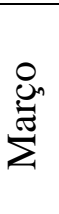 & 震 & $\stackrel{\frac{0}{\pi}}{\sum}$ & 息 & $\stackrel{̊}{\equiv}$ & $\begin{array}{l}\stackrel{0}{0} \\
0 \\
0 \\
00 \\
\&\end{array}$ & 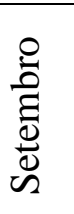 & $\begin{array}{l}\stackrel{0}{0} \\
\stackrel{B}{\Xi} \\
0\end{array}$ & $\begin{array}{l}0 \\
\stackrel{0}{0} \\
\mathbb{0} \\
\text { zे } \\
\text { Z }\end{array}$ & 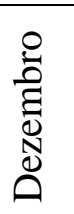 & 胥 \\
\hline $\begin{array}{l}0 \text { a } 5 \\
\text { anos }\end{array}$ & 210 & 136 & 62 & 124 & 86 & 39 & 96 & 72 & 61 & 96 & 74 & 172 & 1228 \\
\hline $\begin{array}{l}6 \text { a } 12 \\
\text { anos }\end{array}$ & 618 & 500 & 357 & 279 & 208 & 289 & 275 & 160 & 163 & 298 & 762 & 960 & 4869 \\
\hline $\begin{array}{l}13 \text { a } 20 \\
\text { anos }\end{array}$ & 615 & 511 & 348 & 666 & 641 & 795 & 551 & 352 & 237 & 639 & 1444 & 874 & 7673 \\
\hline $\begin{array}{l}21 \text { a } 30 \\
\text { anos }\end{array}$ & 801 & 876 & 461 & 1271 & 838 & 794 & 708 & 611 & 492 & 559 & 989 & 897 & 9297 \\
\hline $\begin{array}{l}31 \text { a } 50 \\
\text { anos }\end{array}$ & 1334 & 1362 & 703 & 1132 & 1016 & 542 & 1312 & 905 & 651 & 653 & 914 & 1666 & 12190 \\
\hline $\begin{array}{l}\text { Acima } \\
\text { de } 51 \\
\text { anos }\end{array}$ & 709 & 689 & 351 & 344 & 275 & 228 & 410 & 317 & 191 & 274 & 283 & 804 & 4875 \\
\hline
\end{tabular}

Quadro A.4. Cidades do Paraná que Visitaram Vila Velha

\begin{tabular}{|c|c|c|c|c|c|c|c|c|c|c|c|c|c|}
\hline $\begin{array}{l}\text { Cidades do } \\
\text { Paraná }\end{array}$ & 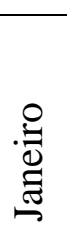 & 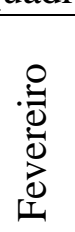 & 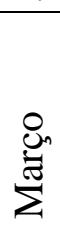 & $\bar{z}$ & 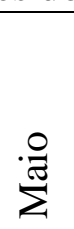 & $\stackrel{\varrho}{\Xi}$ & $\stackrel{\ominus}{\Xi}$ & $\begin{array}{l}0 \\
\stackrel{0}{0} \\
8 \\
800 \\
\&\end{array}$ & 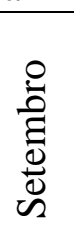 & 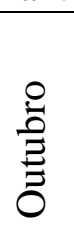 & 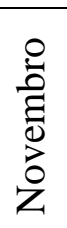 & 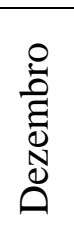 & 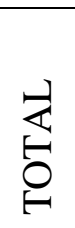 \\
\hline Curitiba & 635 & 1243 & 702 & 1070 & 913 & 730 & 543 & 761 & 502 & 413 & 863 & 786 & 9161 \\
\hline $\begin{array}{l}\text { Ponta } \\
\text { Grossa }\end{array}$ & 323 & 474 & 326 & 629 & 724 & 339 & 335 & 614 & 306 & 586 & 645 & 901 & 6202 \\
\hline Cascavel & 55 & 33 & 3 & 27 & 14 & 7 & 16 & 4 & 41 & 16 & 101 & 41 & 358 \\
\hline Londrina & 182 & 117 & 80 & 91 & 47 & 23 & 130 & 42 & 30 & 80 & 108 & 213 & 1143 \\
\hline Paranaguá & 10 & 0 & 0 & 51 & 3 & 0 & 3 & 0 & 3 & 3 & 8 & 3 & 84 \\
\hline $\begin{array}{l}\text { Campo } \\
\text { Largo }\end{array}$ & 15 & 64 & 30 & 19 & 19 & 0 & 0 & 4 & 5 & 0 & 67 & 72 & 295 \\
\hline Maringá & 161 & 110 & 44 & 73 & 36 & 7 & 61 & 9 & 8 & 20 & 19 & 195 & 743 \\
\hline Toledo & 15 & 26 & 7 & 0 & 0 & 0 & 4 & 0 & 2 & 80 & 30 & 66 & 230 \\
\hline Irati & 15 & 20 & 0 & 8 & 5 & 0 & 6 & 0 & 71 & 15 & 6 & 0 & 146 \\
\hline Araucária & 5 & 25 & 6 & 19 & 0 & 3 & 10 & 5 & 4 & 2 & 0 & 16 & 95 \\
\hline $\begin{array}{l}\text { Francisco } \\
\text { Beltrão }\end{array}$ & 0 & 0 & 0 & 0 & 62 & 0 & 0 & 0 & 3 & 4 & 37 & 9 & 115 \\
\hline $\begin{array}{l}\text { Foz do } \\
\text { Iguaçu }\end{array}$ & 56 & 20 & 7 & 33 & 87 & 4 & 49 & 6 & 11 & 2 & 5 & 19 & 299 \\
\hline Outras & 854 & 593 & 483 & 648 & 438 & 822 & 531 & 447 & 314 & 593 & 1667 & 1353 & 8743 \\
\hline
\end{tabular}


Quadro A.5: Estados do Brasil que Visitaram Vila Velha

\begin{tabular}{|c|c|c|c|c|c|c|c|c|c|c|c|c|c|}
\hline Estados & : & 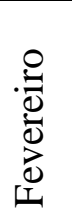 & 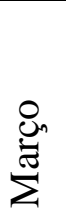 & 寻 & $\frac{0}{\stackrel{\Xi}{\pi}}$ & $\stackrel{\varrho}{\Xi}$ & $\stackrel{\varrho}{\Xi}$ & 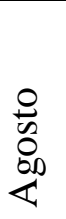 & 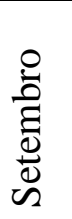 & 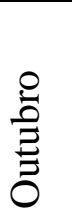 & 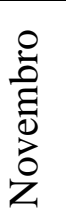 & 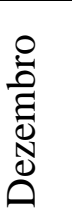 & 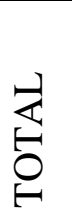 \\
\hline $\mathrm{SC}$ & 415 & 0 & 172 & 333 & 181 & 237 & 406 & 172 & 225 & 182 & 259 & 572 & 3154 \\
\hline $\mathrm{RJ}$ & 192 & 0 & 33 & 67 & 16 & 34 & 101 & 13 & 33 & 46 & 73 & 101 & 709 \\
\hline SP & 638 & 0 & 203 & 498 & 266 & 338 & 823 & 218 & 110 & 220 & 280 & 569 & 4163 \\
\hline $\mathrm{RS}$ & 183 & 0 & 120 & 126 & 136 & 51 & 82 & 19 & 28 & 68 & 161 & 247 & 1221 \\
\hline MT & 50 & 0 & 2 & 0 & 6 & 5 & 6 & 0 & 5 & 7 & 12 & 38 & 131 \\
\hline MS & 95 & 0 & 14 & 10 & 0 & 2 & 18 & 4 & 4 & 0 & 0 & 86 & 233 \\
\hline $\mathrm{RN}$ & 0 & 0 & 0 & 0 & 3 & 0 & 0 & 0 & 0 & 0 & 0 & 0 & 3 \\
\hline DF & 36 & 0 & 0 & 5 & 7 & 1 & 21 & 2 & 8 & 2 & 6 & 60 & 148 \\
\hline $\mathrm{CE}$ & 0 & 0 & 0 & 1 & 2 & 13 & 11 & 2 & 0 & 3 & 2 & 6 & 40 \\
\hline GO & 40 & 0 & 0 & 13 & 3 & 0 & 8 & 0 & 0 & 4 & 3 & 29 & 100 \\
\hline ES & 48 & 0 & 6 & 22 & 6 & 18 & 21 & 7 & 3 & 0 & 23 & 9 & 163 \\
\hline $\mathrm{MG}$ & 50 & 0 & 13 & 22 & 47 & 3 & 56 & 7 & 5 & 12 & 60 & 64 & 339 \\
\hline AM & 15 & 0 & 0 & 5 & 3 & 0 & 0 & 0 & 0 & 4 & 0 & 0 & 27 \\
\hline PA & 0 & 0 & 0 & 0 & 0 & 0 & 12 & 0 & 0 & 0 & 0 & 14 & 26 \\
\hline $\mathrm{AL}$ & 0 & 0 & 0 & 0 & 4 & 0 & 2 & 5 & 0 & 0 & 1 & 0 & 12 \\
\hline $\mathrm{PE}$ & 13 & 0 & 2 & 0 & 6 & 10 & 4 & 0 & 10 & 10 & 4 & 0 & 59 \\
\hline Outras & 172 & 0 & 15 & 34 & 5 & 14 & 20 & 15 & 28 & 28 & 21 & 72 & 424 \\
\hline
\end{tabular}


Quadro A.6: Dados Estatísticos Gerais dos Turistas: Países que Visitam Vila Velha

\begin{tabular}{|c|c|c|c|c|c|c|c|c|c|c|c|c|c|}
\hline Países & : & 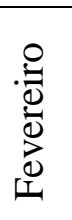 & $\begin{array}{l}\stackrel{\ominus}{\mathcal{E}} \\
\stackrel{\Xi}{\Sigma}\end{array}$ & $\begin{array}{l}\bar{Z} \\
\bar{z}\end{array}$ & $\frac{0}{\stackrel{\pi}{2}}$ & $\stackrel{\varrho}{\Xi}$ & $\stackrel{0}{\equiv}$ & 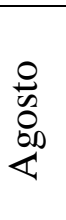 & 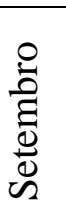 & 象 & 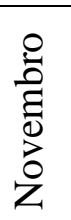 & $\begin{array}{l}\text { 을 } \\
\text { हี } \\
\mathbb{N} \\
\stackrel{0}{0}\end{array}$ & $\stackrel{ت}{\stackrel{Z}{6}}$ \\
\hline Holanda & 0 & 0 & 5 & 2 & 7 & 0 & 12 & 10 & 2 & 0 & 2 & 0 & 40 \\
\hline Itália & 6 & 0 & 0 & 0 & 0 & 0 & 1 & 2 & 0 & 1 & 0 & 6 & 16 \\
\hline USA & 1 & 0 & 0 & 2 & 0 & 2 & 21 & 2 & 9 & 5 & 11 & 1 & 54 \\
\hline Bélgica & 0 & 0 & 0 & 0 & 0 & 0 & 0 & 0 & 3 & 0 & 0 & 0 & 3 \\
\hline Canadá & 2 & 0 & 0 & 0 & 0 & 0 & 4 & 0 & 0 & 0 & 4 & 2 & 12 \\
\hline Moçambique & 0 & 0 & 0 & 0 & 0 & 0 & 0 & 0 & 0 & 0 & 0 & 0 & 0 \\
\hline Portugal & 0 & 0 & 4 & 0 & 0 & 0 & 0 & 0 & 0 & 2 & 0 & 0 & 6 \\
\hline Inglaterra & 0 & 0 & 0 & 2 & 0 & 0 & 3 & 0 & 0 & 1 & 5 & 0 & 11 \\
\hline França & 4 & 0 & 0 & 0 & 2 & 24 & 1 & 13 & 1 & 0 & 7 & 4 & 56 \\
\hline Paraguai & 16 & 0 & 0 & 0 & 4 & 0 & 2 & 2 & 0 & 0 & 0 & 16 & 40 \\
\hline Alemanha & 7 & 0 & 2 & 4 & 5 & 0 & 22 & 24 & 2 & 44 & 7 & 7 & 124 \\
\hline México & 1 & 0 & 0 & 0 & 0 & 0 & 0 & 0 & 1 & 0 & 2 & 1 & 5 \\
\hline Japão & 0 & 0 & 0 & 0 & 0 & 0 & 0 & 0 & 1 & 0 & 0 & 0 & 1 \\
\hline Outros & 17 & 0 & 3 & 5 & 7 & 0 & 7 & 5 & 2 & 8 & 12 & 17 & 83 \\
\hline Total & 54 & 0 & 14 & 15 & 25 & 26 & 73 & 58 & 21 & 61 & 50 & 54 & 451 \\
\hline
\end{tabular}




\section{ANEXO 2: Autorização do IAP para realização de pesquisa no Parque Estadual de Vila Velha.}

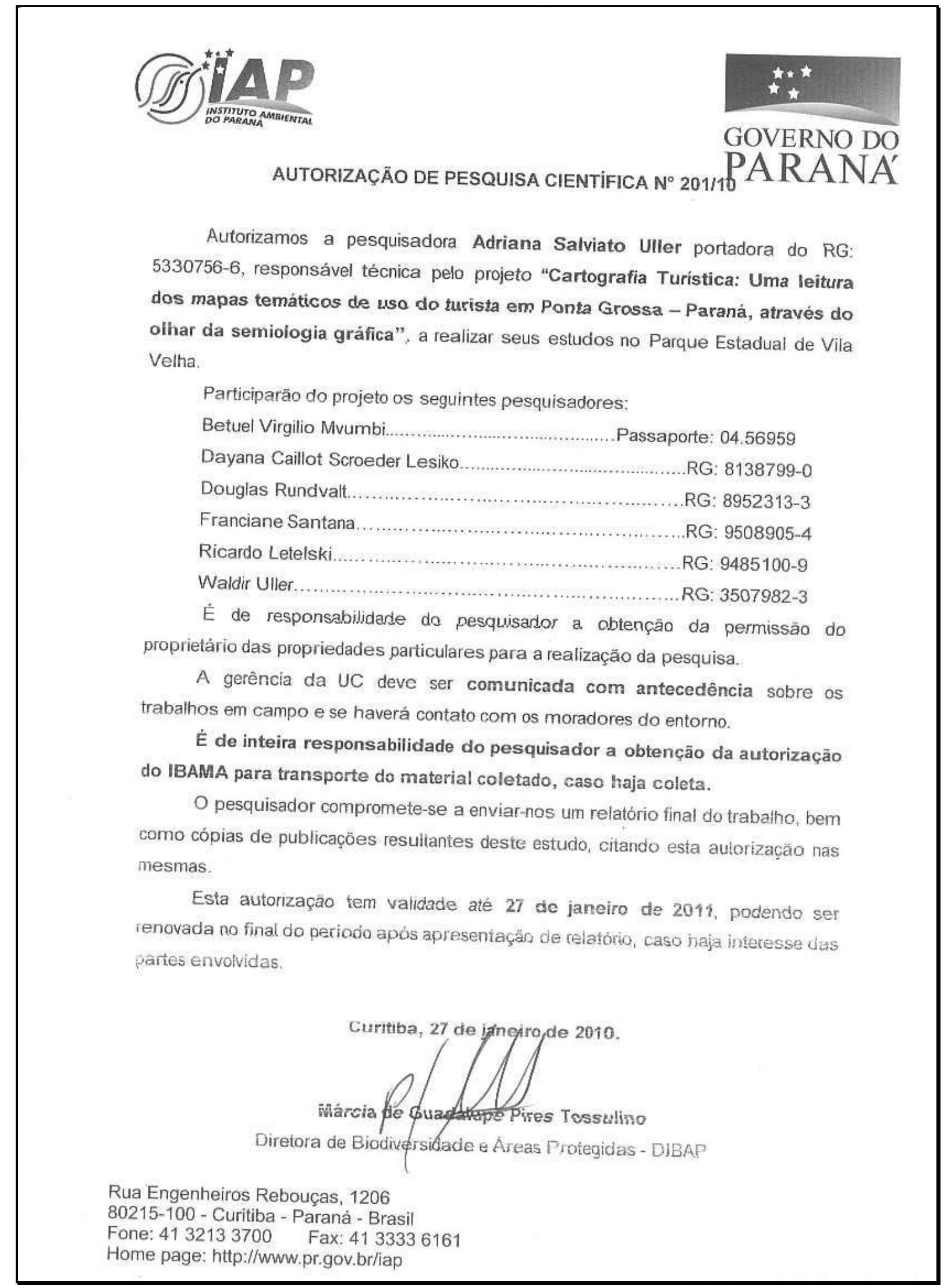




\title{
ANEXO 3: Material de Pesquisa de Campo - Questionário
}

\author{
$\underline{\text { TERMO DE CONSENTIMENTO LIVRE E ESCLARECIDO }}$
}

Você está sendo convidado a colaborar com a pesquisa "CARTOGRAFIA TURÍSTICA: Uma Leitura dos Mapas Temáticos de Uso do Turista em Ponta Grossa - Paraná, Através do Olhar da Semiologia Gráfica" que tem por objetivo analisar o tipo de leitura e representação de paisagem na Cartografia Turística pelos turistas que visitam Ponta Grossa, bem como verificar a necessidade de reformular o material cartográfico produzido para este fim ou dinamizar a sua distribuição.

Sua participação não é obrigatória, você pode se recusar a prestar suas opiniões e sua recusa não trará nenhum prejuízo em relação com a pesquisadora ou com a instituição. Tal participação, no entanto consistirá apenas em responder ao questionário, que é meu procedimento metodológico de pesquisa para elaboração de minha Tese de Doutorado em Geografia Física na USP - Universidade de São Paulo.

As informações obtidas serão confidenciais, mesmo que identificadas aqui para o meu controle, ou seja, assegura-se o sigilo pleno quanto à sua participação. Os dados serão divulgados de modo estatístico, e os breves destaques pertinentes não terão qualquer forma de identificação.

Você receberá uma cópia deste termo, no qual constam o telefone e o endereço da pesquisadora, podendo tirar suas dúvidas sobre a pesquisa e sua participação.

Desde já agradeço gentilmente sua preciosa colaboração e solicito que sejam bem sinceros em suas considerações.

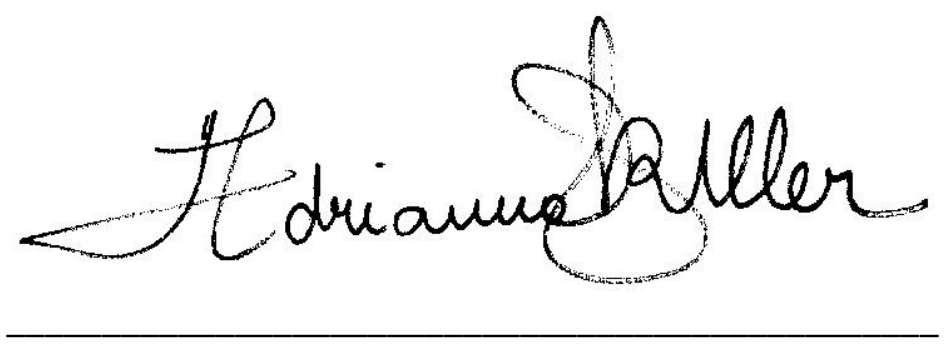

Doutoranda: Adriana Salviato Uller

Contatos:

Fones (42) $32290098-99457430$

Email: adri.uller@yahoo.com.br

Estagiário: 


\section{TERMO DE CONSENTIMENTO LIVRE E ESCLARECIDO}

Você está sendo convidado a colaborar com a pesquisa "CARTOGRAFIA TURÍSTICA: Uma Leitura dos Mapas Temáticos de Uso do Turista em Ponta Grossa - Paraná, Através do Olhar da Semiologia Gráfica" que tem por objetivo analisar o tipo de leitura e representação de paisagem na Cartografia Turística pelos turistas que visitam Ponta Grossa, bem como verificar a necessidade de reformular o material cartográfico produzido para este fim ou dinamizar a sua distribuição.

Sua participação não é obrigatória, você pode se recusar a prestar suas opiniões e sua recusa não trará nenhum prejuízo em relação com a pesquisadora ou com a instituição. Tal participação, no entanto consistirá apenas em responder ao questionário, que é meu procedimento metodológico de pesquisa para elaboração de minha Tese de Doutorado em Geografia Física na USP - Universidade de São Paulo.

As informações obtidas serão confidenciais, mesmo que identificadas aqui para o meu controle, ou seja, assegura-se o sigilo pleno quanto à sua participação. Os dados serão divulgados de modo estatístico, e os breves destaques pertinentes não terão qualquer forma de identificação.

Você receberá uma cópia deste termo, no qual constam o telefone e o endereço da pesquisadora, podendo tirar suas dúvidas sobre a pesquisa e sua participação.

Desde já agradeço gentilmente sua preciosa colaboração e solicito que sejam bem sinceros em suas considerações.

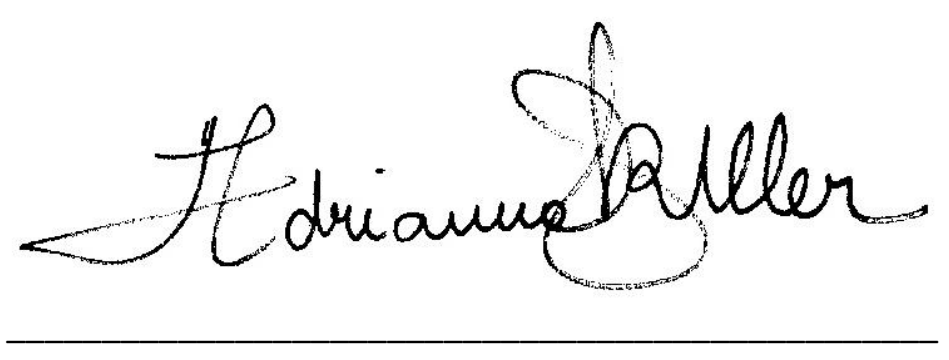

Doutoranda: Adriana Salviato Uller - RG 5.330.756-6

Contatos:

Fones (42) $32290098-99457430$

Email: adri.uller@yahoo.com.br

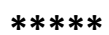

Declaro que entendi o objetivo de minha participação na pesquisa e concordo em participar.

Nome:

Email ou fone para contato (se necessário):

Assinatura: 
DADOS PESSOAIS

\begin{tabular}{|lc|}
\hline Nome: & idade: anos \\
\hline Cidade/Estado: & \\
\hline Data da entrevista: & \\
\hline Local da entrevista: & \\
\hline
\end{tabular}

\section{FORMAÇÃO PROFISSIONAL}

Escolaridade: ( ) Sem Escolaridade

( ) Ensino Fundamental (até 8_ Série)

( ) Ensino Médio ( )Normal ou ( )Técnico-Qual?

( ) Ensino Superior - Área:

( ) Pós-Graduação/Qual nível? ( )especialização ( )mestrado ( ) doutorado

Profissão Exercida:

\section{INFORMAÇÕES SOBRE A VISITA TURÍSTICA}

1.Forma de Condução: ( ) veículo próprio

( ) ônibus coletivo local

( ) Van ou ônibus de Turismo/Excursões

( ) transporte escolar

2. Frequência de práticas turísticas, passeios e viagens: ( ) quase não viaja

( ) viaja só para fins de estudo

( ) viaja e ou visita lugares só em férias

( ) viaja e visita lugares com frequência

3. Tempo de permanência no município: ( ) menos de um dia

( ) um dia

( ) de dois dias à uma semana

( ) mais de uma semana

( ) resido no município

4. Local de permanência: （ ) casa de familiares

( ) Hotel

( ) outros: qual?

5. Quais os lugares de interesse em visitações turísticas em Ponta Grossa?

( ) Arenitos Vila Velha

( ) Furnas

( ) Lagoa Dourada 


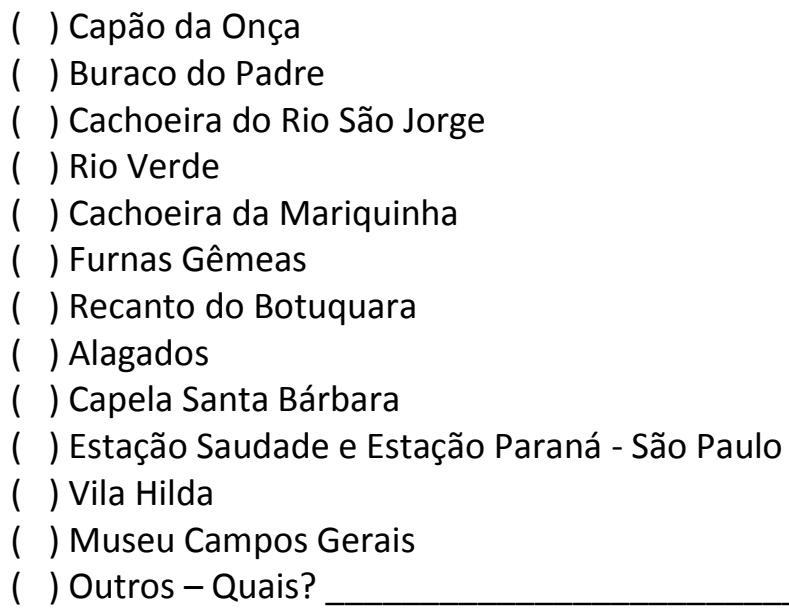

( ) Vila Hilda

( ) Museu Campos Gerais

( ) Outros-Quais?

6. Você já sabia de todas estas potencialidades turísticas de Ponta Grossa?
( ) sim - através do que?

( ) não-porquê?

7. Que motivos te impediriam de visitar estes lugares?
( ) falta de condições financeiras
( ) não sabe onde se localizam
( ) dificuldade de acesso
( ) falta de tempo

8. Para se localizar durante sua visitação aos lugares você costuma se utilizar de:

( ) guias e monitores turísticos

( ) mapas e folders de informação e localização

( ) outros- quais?

9. Quanto ao material cartográfico sobre os atrativos turísticos do município:

( ) você considera super importante e está se guiando por eles

( ) você considera irrelevante porque não costuma se guiar por mapas

( ) você considera desnecessário por que eles não informam o que você deseja

( ) você não recebeu, mas gostaria de tê-los em mão por que os considera importante (aí destaque o por que):

( ) Você não recebeu e considera desnecessário por que existem outros meios de informação

10. Diante dos dois exemplares de material cartográfico turístico apresentados pelo (a) entrevistador (a) qual te apresenta maior eficácia quanto à suas necessidades turísticas?
( ) material 1
( ) material 2

Por quê? 


\section{2ª PARTE DA ENTREVISTA:}

Avalie os dois materiais quanto aos itens sugeridos e registre sua opinião de satisfação utilizando os seguintes códigos numéricos:

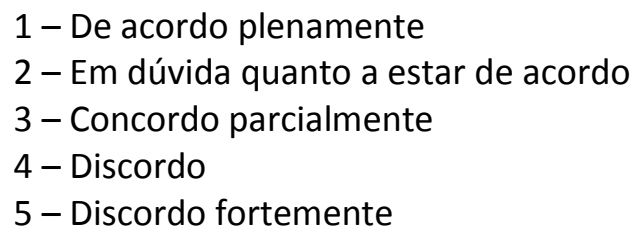

\section{ITENS A SEREM AVALIADOS}

1. Tamanho do material completo

2. Disposição das Informações no material completo

3. Tipo de llustrações presentes no material

4. Apresentação da escala de distâncias no mapa

5. Apresentação da legenda simbólica do mapa

6. Forma de Orientação das localidades no mapa para os turistas

7. Variedade e tipo de símbolos utilizados no mapa

8. Cores empregadas no mapa

9. Tamanho das informações e símbolos no mapa

10. Quantidade de informações no mapa

11. Síntese das informações do mapa

12. Distribuição espacial dos lugares turísticos no mapa

13. Informação de melhores acessos aos lugares especificando os tipos de vias

14. Identificação de lugares como: terminal rodoviário, hotel, restaurante, hospital, ruas principais.

15. Legenda informando o tipo temático de atrativo turístico: rural, natural, histórico, religioso, de aventura, para banho.

Observações e comentários a salientar: 


\section{ANEXO 4. Material 1. Utilizado para Análise dos Entrevistados}

$$
\text { MAPA 31: Ponta Grossa Turismo }(1)^{49}
$$

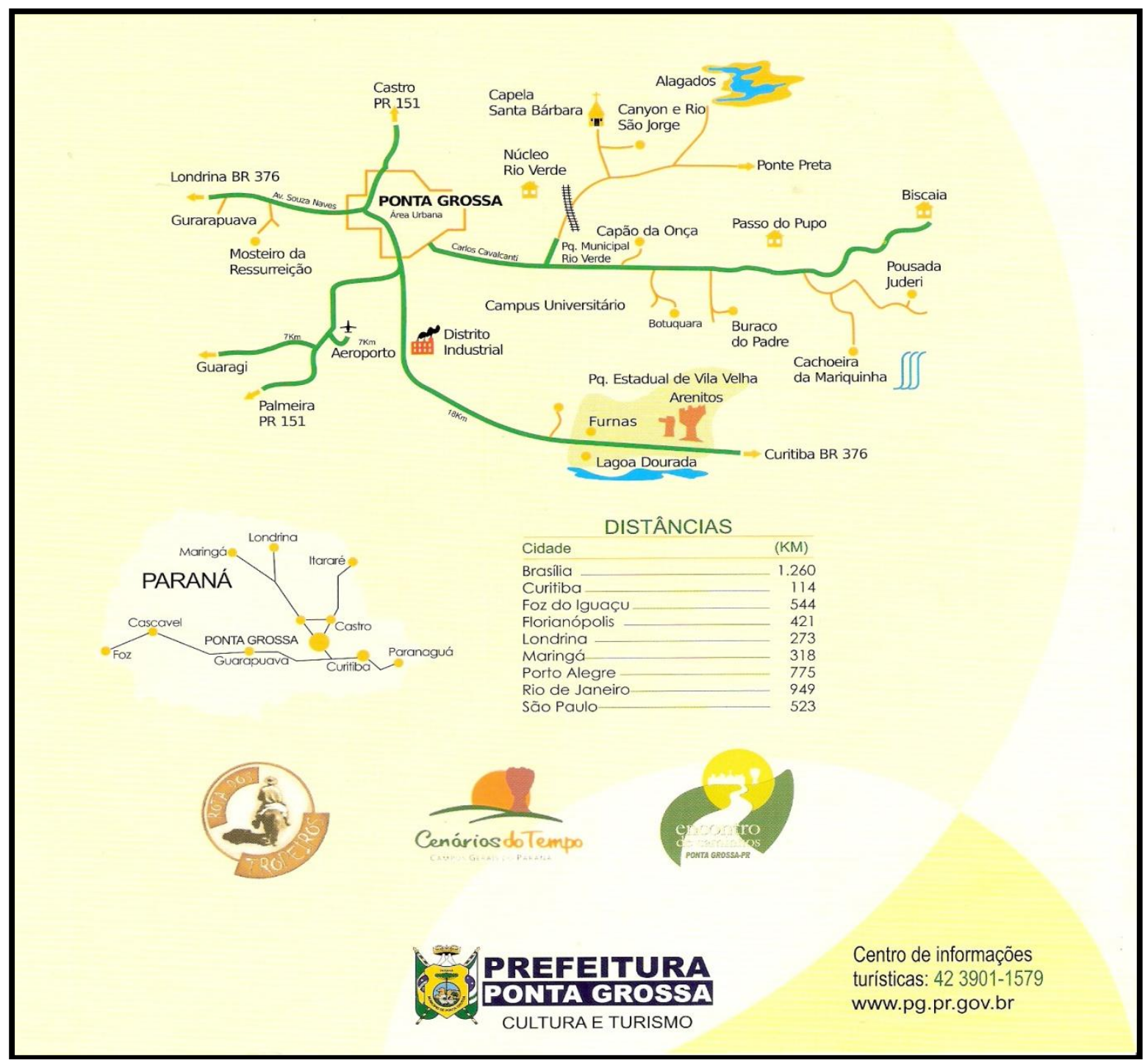

\footnotetext{
${ }^{49}$ No documento original impresso o anexo está em tamanho grande, envelopado.
} 
ANEXO 5. . Material 2. Utilizado para Análise dos Entrevistados

MAPA 32: Ponta Grossa Turismo (2) ${ }^{50}$

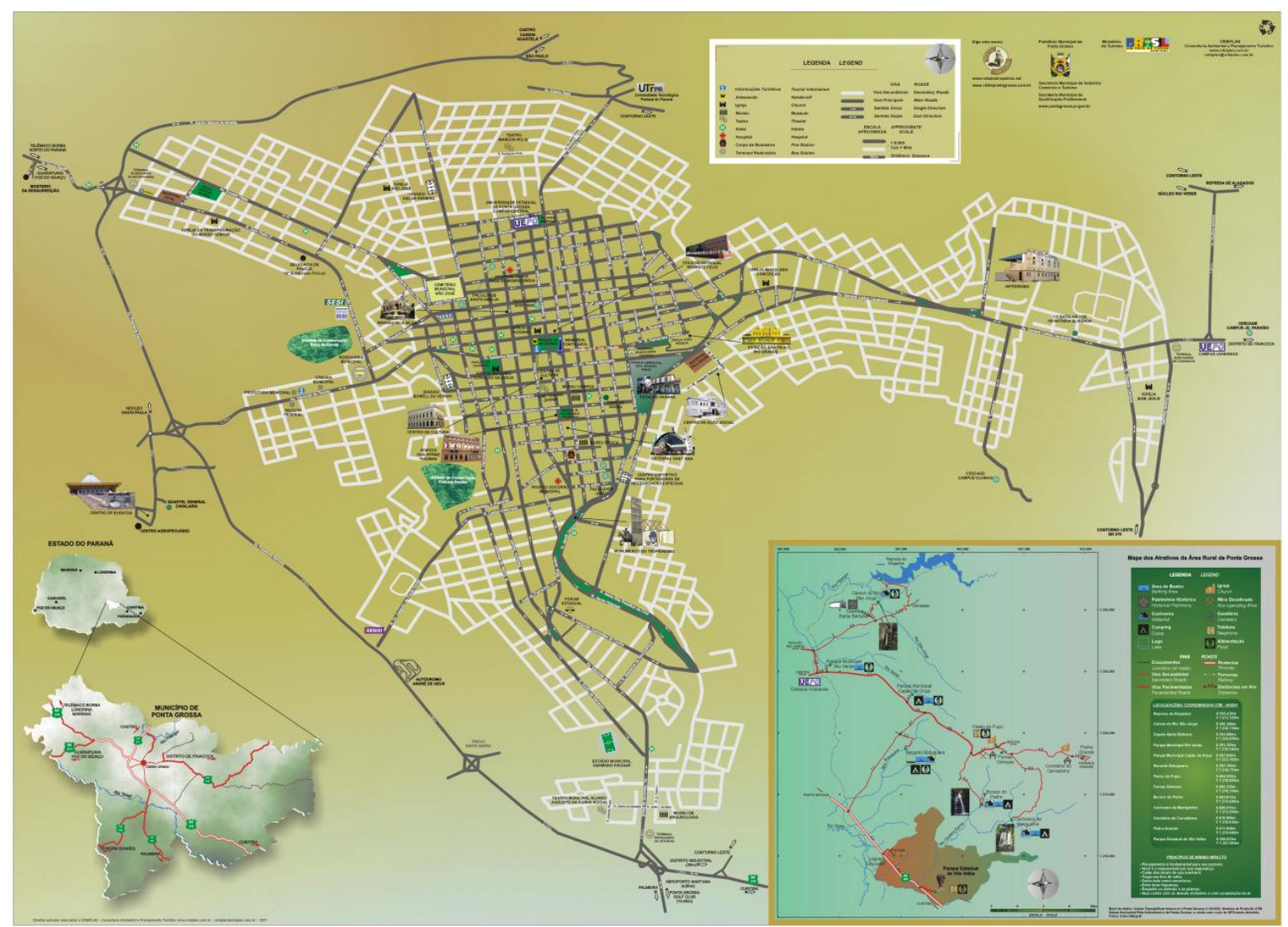

${ }^{50}$ No documento original impresso o anexo está em tamanho grande, envelopado. 
ANEXO 6 . Ponta Grossa nos Campos Gerais - Aspectos Turísticos MAPA 33: Ponta Grossa Turismo nos Campos Gerais ${ }^{51}$

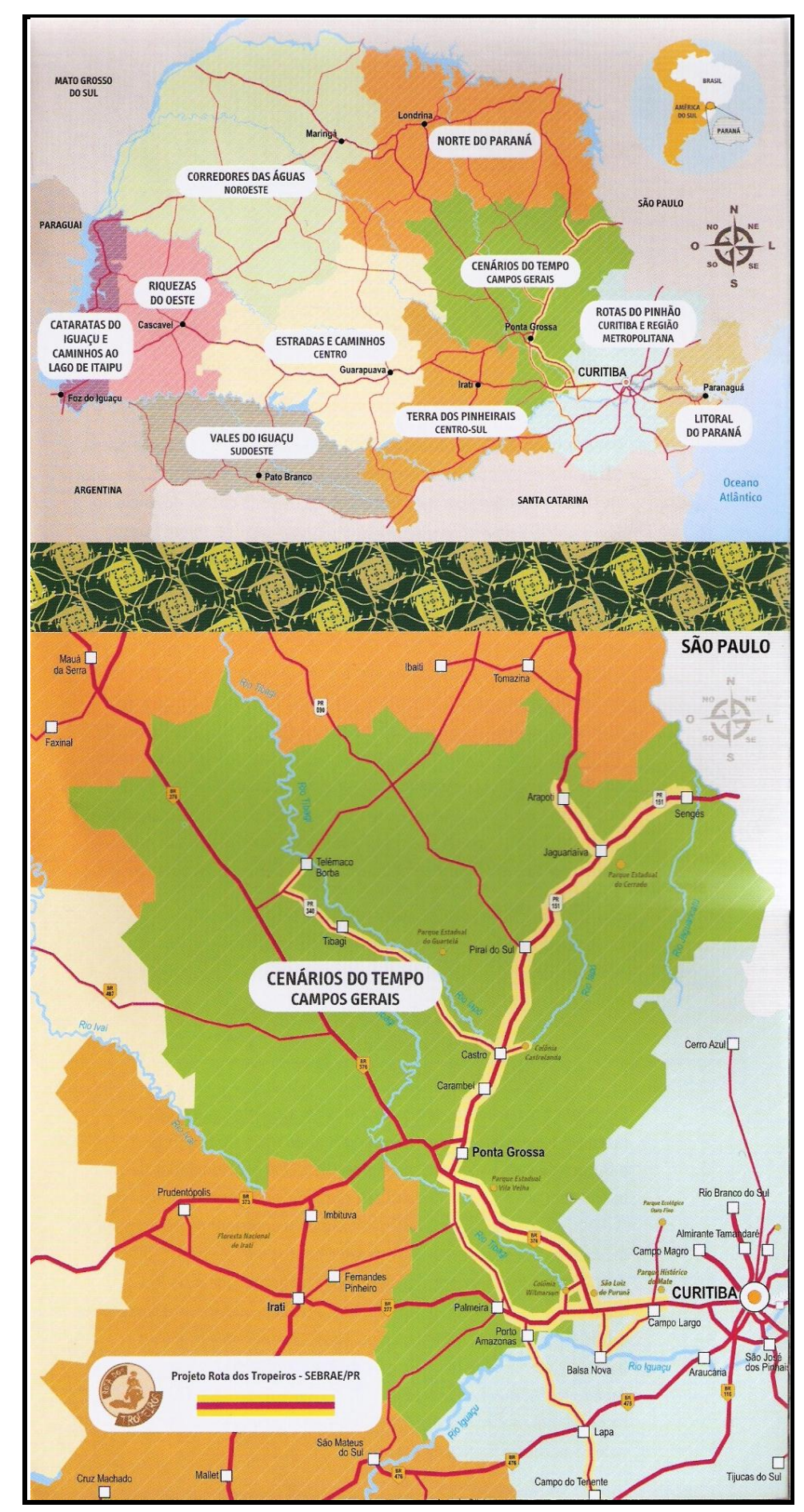

${ }^{51}$ No documento original impresso o anexo está em tamanho grande, envelopado. 